Universidad deValladolid

PROGRAMA DE DOCTORADO EN DERECHO

TESIS DOCTORAL:

\title{
ANÁLISIS DEL VEREDICTO DEL TRIBUNAL DEL JURADO EN CASOS DE HOMICIDIO Y ASESINATO EN CASTILLA Y LEÓN (1995-2017)
}

Presentada por María Angélica Gutiérrez Gutiérrez para optar al grado de Doctora por la Universidad de Valladolid

\author{
Dirigida por: \\ Dr. D. Ángel José Sanz Morán
}




\section{ÍNDICE}

\section{ÍNDICE DE GRÁFICOS.}

ÍNDICE DE TABLAS.

LISTA DE ABREVIATURAS.

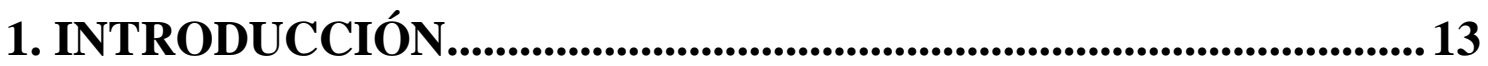

1.1. Justificación del tema elegido para el trabajo................................13

1.2. Material utilizado y metodología de trabajo. ............................... 18

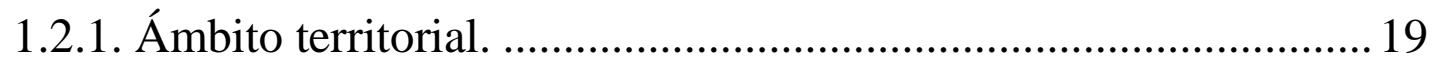

1.2.2. Ámbito material. ....................................................................... 19

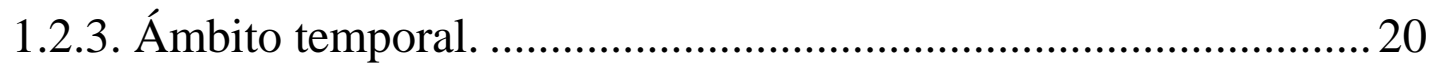

2

2. PERSPECTIVA HISTÓRICO-JURÍDICA Y COMPARADA DE LOS DELITOS CONTRA LA VIDA............................................23

2.1. Evolución de los delitos de homicidio y asesinato

en la historia de los códigos penales españoles....................................23

2.1.1. El Código Penal de 1822 ............................................................... 23

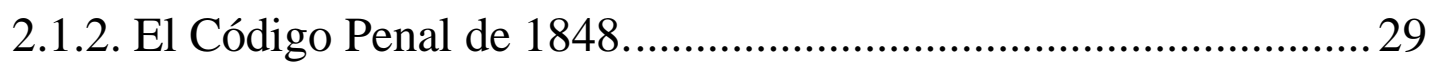

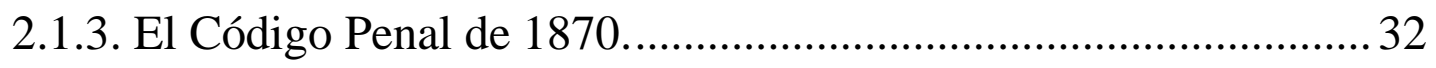

2.1.4. El Código Penal de 1928................................................................ 35

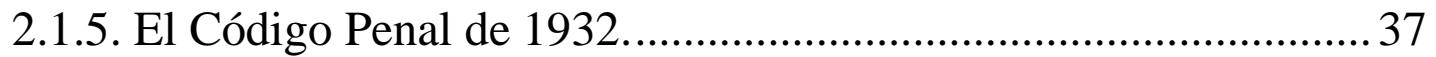

2.1.6. El Código Penal de 1944

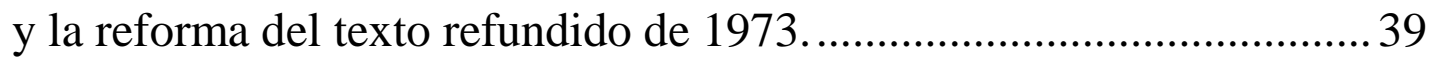

2.1.7. El Código Penal de 1995 ................................................................ 40 
2.2. Derecho comparado.

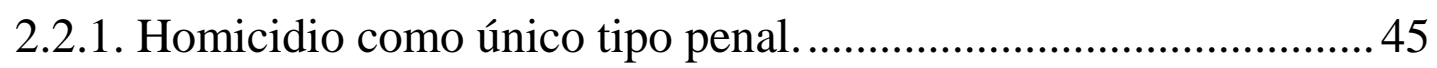

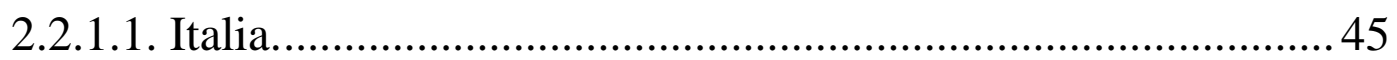

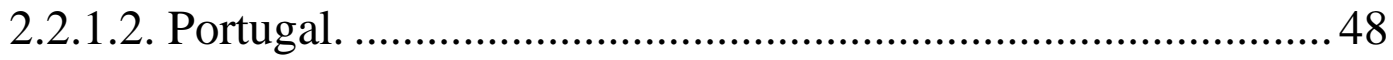

2.2.2. Homicidio y asesinato como dos tipos penales diferenciados..... 49

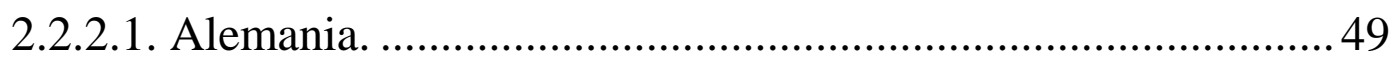

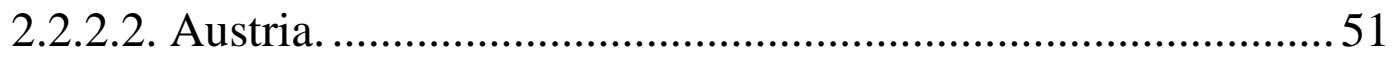

2.2.2.3. Bélgica............................................................................. 52

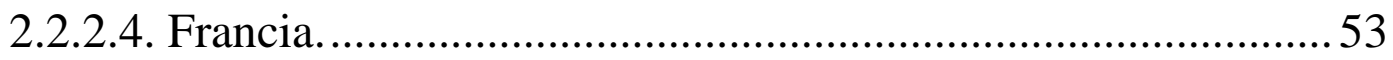

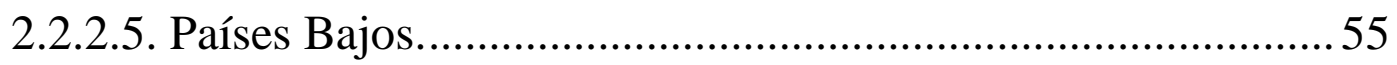

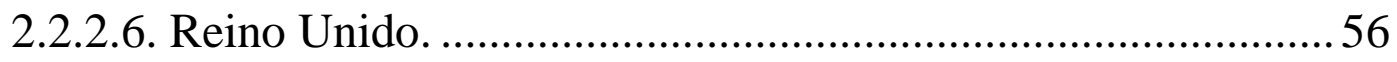

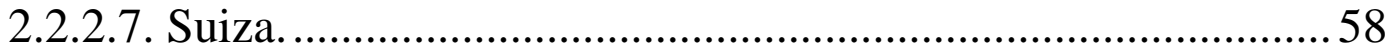

3

3. ESTUDIO DE LOS DELITOS CONTRA LA VIDA EN EL ORDENAMIENTO JURÍDICO ESPAÑOL VIGENTE. ....................61

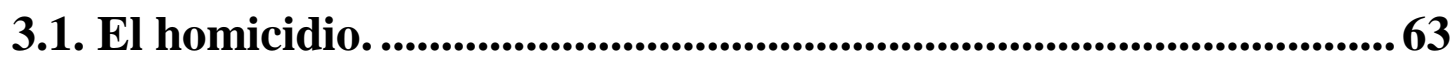

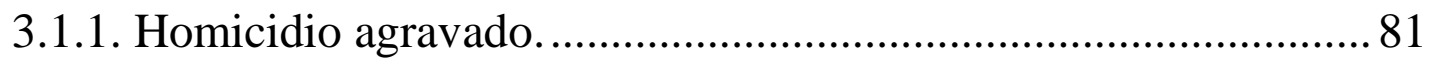

3.2. El asesinato .......................................................................................................... 87

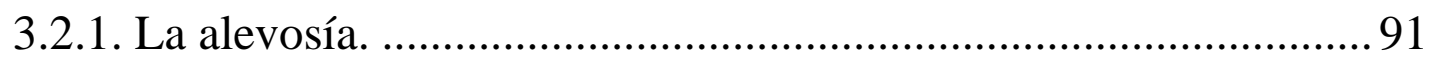

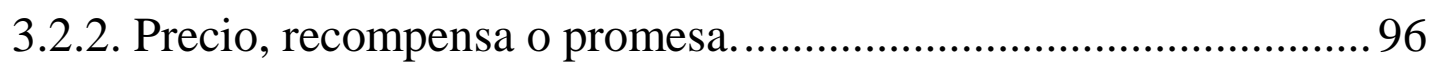

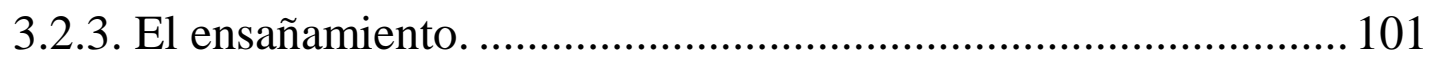

3.2.4. Para facilitar la comisión de otro delito o

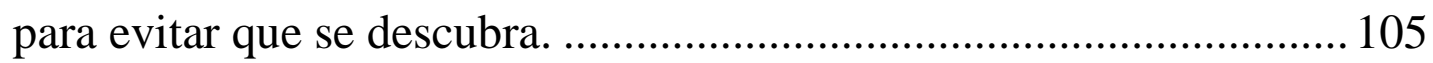

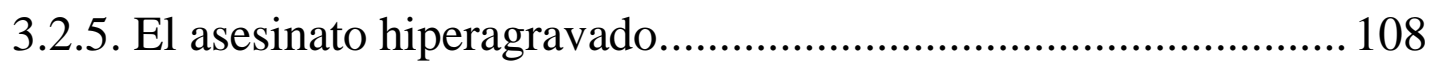


4. LA INSTITUCIÓN DEL JURADO.

\subsection{Clasificación de los distintos tipos de jurado y}

sus diferencias entre el sistema español y el de otros países.

4.1.1. Modelo anglosajón o puro........................................................... 119

4.1.1.1. Inglaterra y Gales............................................................... 120

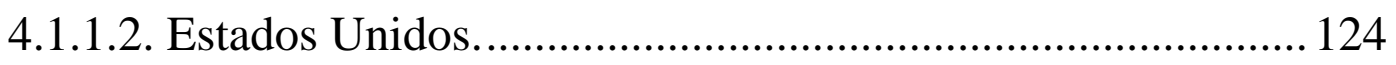

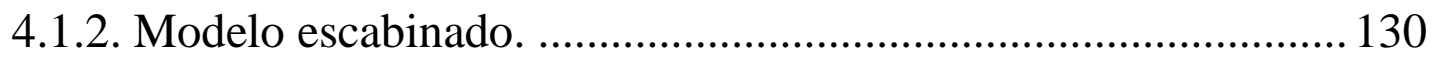

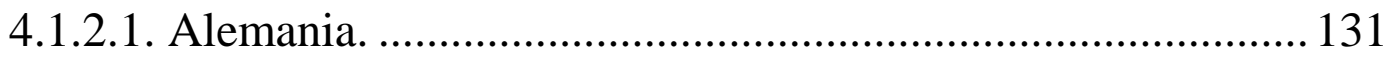

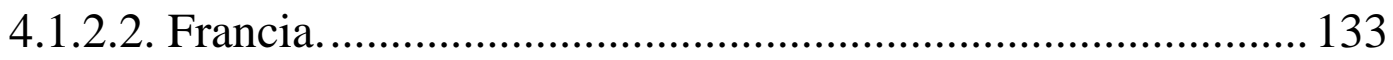

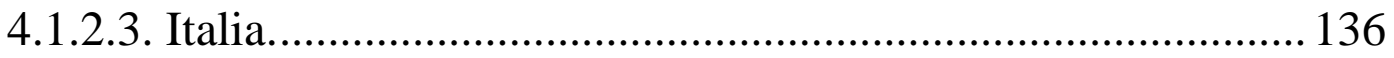

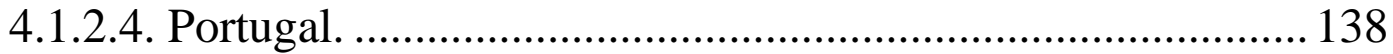

4.1.3. Ventajas e inconvenientes de cada modelo................................ 140

4.2. Historia del jurado en España. ............................................................... 141

4.2.1. Situación en España a comienzos del siglo XIX

hasta el desarrollo de la primera ley específica. ................................... 141

4.2.2. La primera Ley del Jurado en España......................................... 161

\subsection{La Ley Orgánica 5/1995, de 22 de mayo,}

del Tribunal del Jurado................................................................................ 169

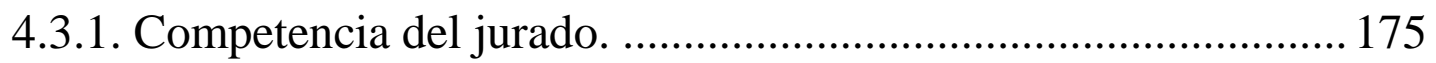

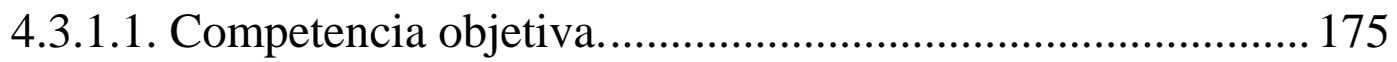

4.3.1.2. Competencia territorial del jurado. ...................................... 179

4.3.1.3. Alteración de las normas de competencia por conexidad.... 180

4.3.2. Composición del Tribunal del Jurado.......................................... 182

4.3.2.1. Quiénes pueden ser jurado en España................................... 185

4.3.3. Incoación, instrucción y fase del juicio oral.. .............................. 188

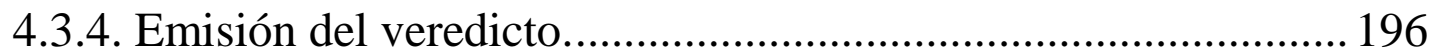

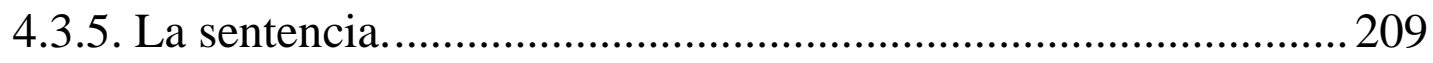


6

6. RESULTADOS Y DISCUSIÓN.

6.1. Descripción de las variables

y los resultados de la investigación.

6.1.1. Resultados respecto a los veredictos emitidos

por el jurado en las Audiencias Provinciales. 240

6.1.1.1. Variables analizadas de manera independiente. 241

6.1.1.2. Variables cruzadas. 255

6.1.2. Resultados respecto a los recursos de apelación ante el Tribunal Superior de Justicia de Castilla y León. 270

6.1.3. Resultados respecto a los recursos de casación ante el Tribunal Supremo. 286

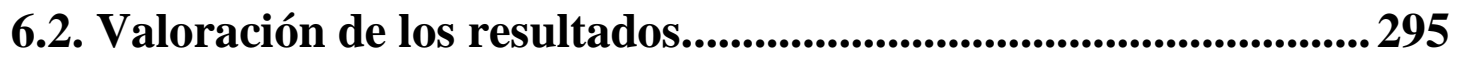

6.3. Estadísticas del Consejo General del Poder Judicial. 300

7

7. CONCLUSIONES 305

8. JURISPRUDENCIA 309 


\section{ÍNDICE DE GRÁFICOS}

Gráfico 01: tipos delictivos juzgados por el jurado. ................................ 217

Gráfico 02: comparativa entre estos delitos por provincias....................... 218

Gráfico 03: número de homicidios enjuiciados....................................... 219

Gráfico 04: asesinatos en función de la circunstancia que los califica..... 219

Gráfico 05: distribución de los homicidios y los asesinatos

en función del sexo de la persona que los ha cometido.......................... 220

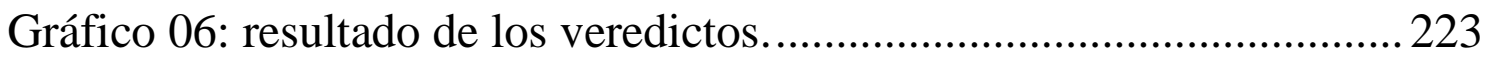

Gráfico 07: resultado de los veredictos separados

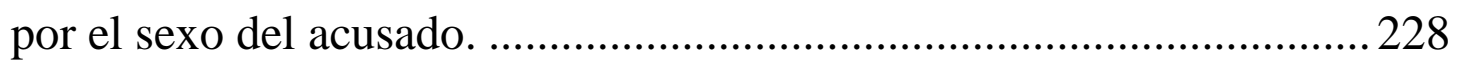

Gráfico 08: sentencias del Tribunal Superior de Justicia en apelación. ... 233

Gráfico 09: sentencias del Tribunal Supremo en casación. ........................ 237

Gráfico 10: porcentajes para la variable delito. .......................................... 242

Gráfico 11: porcentajes para el valor homicidio........................................ 243

Gráfico 12: veredictos del jurado en los homicidios. ................................ 246

Gráfico 13: homicidios recurridos en apelación al TSJ.............................. 247

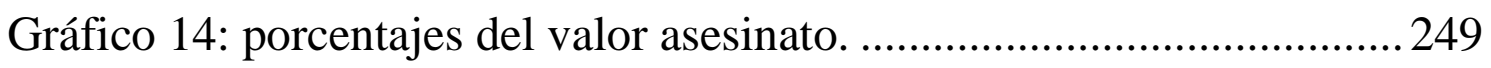

Gráfico 15: asesinatos recurridos en apelación al TSJ.............................. 251

Gráfico 16: porcentajes para la variable veredicto. .................................... 252

Gráfico 17: porcentajes para la variable sexo...........................................253

Gráfico 18: porcentajes para la variable recurso....................................... 255

Gráfico 19: porcentajes para las variables cruzadas delito y veredicto.... 259

Gráfico 20: porcentajes para las variables cruzadas delito y sexo............. 262

Gráfico 21: porcentajes para las variables cruzadas delito y recurso. ...... 264

Gráfico 22: porcentajes para las variables cruzadas veredicto y sexo...... 267

Gráfico 23: porcentajes para las variables cruzadas sexo y recurso. ........ 269

Gráfico 24: porcentaje de la confirmación/no confirmación

del TSJ tras el recurso de apelación. 
Gráfico 25: porcentajes para las variables cruzadas veredicto de la AP y fallo del recurso al TSJ

Gráfico 26: porcentajes para las variables cruzadas delito y provincia.... 279

Gráfico 27: porcentajes de la variable recurso por provincias. 280

Gráfico 28: porcentajes para las variables cruzadas provincias y recurso al TSJ. 285

Gráfico 29: porcentaje de la variable recurso de casación al TS. 286

Gráfico 30: porcentaje resoluciones confirmadas/no confirmadas en casación por el TS. 287

Gráfico 31: porcentajes para las variables cruzadas veredicto AP y recurso de casación al TS.

Gráfico 32: porcentajes para las variables cruzadas delito y recurso de casación al TS.

Gráfico 33: porcentajes para las variables cruzadas sexo y recurso de casación al TS. 295

\section{ÍNDICE DE TABLAS}

Tabla 01: Evolución de las penas del homicidio y el asesinato.

Fuente: elaboración propia.

Tabla 02: Los tipos penales en derecho comparado

y sus correspondientes penas. Fuente: elaboración propia.

Tabla 03: veredictos emitidos por el jurado en la Audiencia Provincial. . 224

Tabla 04: sentencias dictadas por el TSJ en apelación.

Tabla 05: sentencias dictadas por el TS en casación. 235

Tabla 06: Enjuiciados por delito. 301 


\section{LISTA DE ABREVIATURAS}

AD - Antecedente de Derecho.

AN - Audiencia Nacional.

AP - Audiencia Provincial.

Art. - Artículo.

BOE - Boletín Oficial del Estado.

Cap. - Capítulo.

CCAA - Comunidades Autónomas.

CE - Constitución Española de 1978.

CEDH - Convención Europea de Derechos Humanos.

CG - Cortes Generales.

CGPJ - Consejo General del Poder Judicial.

Cols. - Colaboradores.

Coord/s. - Coordinador / Coordinadores.

CP - Código Penal.

CPP - Code de Procédure Pénale (Código de Procedimiento Penal en Francia).

DA - Disposición Adicional.

DT - Disposición Transitoria.

D-L - Decreto-Lei (Portugal).

Dir/s. - Director / Directores.

ed. - Edición. 
EEUU - Estados Unidos.

EM - Exposición de Motivos.

etc. - Etcétera.

FD - Fundamento de Derecho.

FJ - Fundamento jurídico.

GVG - Gerischtsverfassungsgesetz (Ley Orgánica de Tribunales en Alemania).

Ibid. - Ibidem.

$J A-J u r i e s$ Act (Derecho inglés).

LECr - Ley de Enjuiciamiento Criminal.

LO - Ley Orgánica.

LOFTJ - Ley de Organización y Funcionamiento de los Tribunales (Portugal).

LOGP - Ley Orgánica General Penitenciaria.

LOPJ - Ley Orgánica del Poder Judicial.

LOREG - Ley Orgánica del Régimen Electoral General.

LOTJ - Ley Orgánica del Tribunal del Jurado.

No/n - Número.

ONU - Organización de las Naciones Unidas.

Op. cit. - Obra citada.

Pág. / págs. - Página / páginas.

§ - Parágrafo (Código Penal alemán). 
RD - Real Decreto.

RDL - Real Decreto Ley.

s. - Siglo.

SAP AV - Sentencia de la Audiencia Provincial de Ávila.

SAP BU - Sentencia de la Audiencia Provincial de Burgos.

SAP LE - Sentencia de la Audiencia Provincial de León.

SAP P - Sentencia de la Audiencia Provincial de Palencia.

SAP SA - Sentencia de la Audiencia Provincial de Salamanca.

SAP SG - Sentencia de la Audiencia Provincial de Segovia.

SAP SO - Sentencia de la Audiencia Provincial de Soria.

SAP VA - Sentencia de la Audiencia Provincial de Valladolid.

SAP ZA - Sentencia de la Audiencia Provincial de Zamora.

SPSS - Statistical Pakcage for the Social Sciences.

ss. - y siguientes.

STC - Sentencia del Tribunal Constitucional.

STEDH - Sentencia del Tribunal Europeo de Derechos Humanos.

StGB - Strafgesetzbuch (Código Penal de Alemania).

STJCyL - Sentencia del Tribunal Superior de Justicia de Castilla y León.

STS - Sentencia del Tribunal Supremo.

TC - Tribunal Constitucional.

TEDH - Tribunal Europeo de Derechos Humanos. 
Tít. - Título.

TJ - Tribunal del Jurado.

TS - Tribunal Supremo.

TSJ - Tribunal Superior de Justicia.

TSJCyL - Tribunal Superior de Justicia de Castilla y León.

UE - Unión Europea.

vid. - Véase.

Vol. - Volumen. 


\section{INTRODUCCIÓN}

\subsection{Justificación del tema elegido para el trabajo.}

La implantación del jurado en España mediante la Ley Orgánica 5/1995, de 22 de mayo, del Tribunal del Jurado, como método de participación de los ciudadanos en la Administración de Justicia, es un tema bastante discutido y que aún plantea mucha desconfianza entre la población. Por una parte, los partidarios de esta institución alegan que es una garantía de libertades y fomenta la democratización de la Justicia. Por otra, sus detractores consideran que los ciudadanos legos no deberían juzgar sino que ha de ser esta una función exclusiva de los profesionales.

Los casos más mediáticos de asesinatos y determinados delitos económicos reabren el debate social acerca del jurado y provocan cierto escepticismo en la fiabilidad de sus miembros, sobre todo si se produce algún error en su veredicto.

Los delitos contra la vida son los más execrables y los que se castigan con mayores penas en nuestro Código Penal, motivo por el que cabe preguntarse si unos hechos tan graves y que hoy en día pueden llegar a penarse con prisión permanente revisable, introducida en nuestro ordenamiento en 2015, son los idóneos para ser juzgados por ciudadanos. El hecho de que estos casos de asesinato, con los que la sociedad se sensibiliza especialmente, aparezcan con tanta frecuencia en los medios de comunicación, provoca que no podamos evitar que el jurado conozca múltiples detalles de los procedimientos, lo que siembra la duda acerca de si es el organismo más adecuado para enjuiciar a una persona por un delito tan grave. 
Uno de los mayores problemas con los que nos encontramos en España es sobre todo su falta de continuidad. El jurado se ha ido implantando o derogando dependiendo del régimen político existente y, por tanto, de la legislación vigente en cada momento, por lo que no adquiere la estabilidad necesaria para arraigarse en la sociedad y que los ciudadanos lo aprecien como algo normal y positivo. Sin embargo, en los países anglosajones ocurre lo contrario.

En este contexto y ante esa duda nos planteamos dos cuestiones que desarrollaremos a lo largo de la presente investigación:

- Por un lado, si realmente el veredicto que emiten los jurados en delitos de homicidio y asesinato es de culpabilidad en más ocasiones, al existir esa percepción general de que estos tipos ilícitos no se castigan con la suficiente dureza.

- Y, por otro, no solo si los jurados son especialmente severos en su veredicto votando más veces por la culpabilidad que por la no culpabilidad, sino la posibilidad de compararlos con los jueces y ver quiénes son más estrictos, si los legos o los profesionales, o si lo que sucede es que en los mismos casos actúan de igual manera.

Dado que estos delitos son juzgados por el jurado, es imposible saber qué hubiera ocurrido si el enjuiciamiento lo hubiese realizado un tribunal de profesionales. Lo que sí podemos conocer es qué sucede cuando las sentencias vinculadas por dichos veredictos son recurridas y, por lo tanto, analizadas exclusivamente por los profesionales conocedores del Derecho. Por ese motivo, se examinarán las sentencias de las Audiencias Provinciales con sus correspondientes recursos, tanto en apelación al Tribunal Superior de Justicia, en este caso de Castilla y León, como en casación ante el Tribunal Supremo y, de esa forma, ver si en el mismo supuesto, el tribunal profesional ha mantenido el criterio del popular o lo ha 
modificado, en cuyo caso comprobaremos en qué porcentaje de juicios el resultado hubiera sido diferente de haber sido juzgado por miembros de la magistratura y así hacer un estudio comparativo con los casos en los que, tras un recurso, los tribunales superiores han emitido un fallo en sentido contrario.

Desde una perspectiva jurídica, previamente habremos de conocer con más detalle los delitos objeto de las sentencias y la propia institución, tomando como base las fuentes principales de esta investigación, a saber, la legislación, la jurisprudencia y la doctrina. Por eso, en primer lugar se hace un estudio de los delitos contra la vida, concretamente los arts. 138, 139 y 140 del Código Penal, relativos al homicidio y el asesinato, con explicación de cada una de las circunstancias que lo califican, dentro del ordenamiento jurídico español. Hay que advertir que, al no ser el propósito de esta investigación, no se analizan en profundidad, aunque sí realizamos un examen de los tipos básicos, agravados y sus elementos.

Se lleva a cabo un recorrido histórico de estas dos figuras penales desde el comienzo de la codificación en el siglo XIX, partiendo del Código Penal de 1822 y los numerosos textos de los dos últimos siglos, hasta la norma vigente de 1995, con especial referencia a la reforma operada por la Ley Orgánica 1/2015, de 30 de marzo, por la que se modifica el Código Penal, con el fin de comprobar que, al ser de tal gravedad, siempre han estado regulados aunque han ido sufriendo modificaciones en sus modalidades y sus penas y así se hará una comparativa de los tipos, las penas aplicables, etc., todo apoyado con jurisprudencia de la Sala Segunda del Tribunal Supremo.

Asimismo, se expone el resultado del análisis del derecho comparado europeo mediante la búsqueda de legislación internacional, a través de sus códigos y leyes penales, para observar cómo se regulan ambos delitos en 
otros países de nuestro entorno, haciendo hincapié en que algunos de ellos lo tipifican como en España (Alemania, Francia...) mientras que otros lo hacen con un único tipo penal, donde el equivalente al asesinato es el homicidio agravado (casos de Italia o Portugal). De esta forma seremos capaces de analizar si las penas en nuestro ordenamiento se corresponden aproximadamente con las de otros estados europeos o si nuestra legislación prevé penas más o menos graves que los demás países.

Tras esta investigación en materia penal, posteriormente nos detendremos en el estudio de la institución del jurado, cuestionada desde sus comienzos pero también con valedores que lograron llevar a cabo su implantación, a pesar de la oposición de la mayoría de la doctrina, y tras la que fue evolucionando y estableciéndose paulatinamente hasta nuestros días.

Como ejemplo, antes de que existiera una Ley del Jurado, al ser competencia de este procedimiento los delitos de cometidos por medio de la imprenta, dicho proceso se regulaba en la Ley de Libertad de Imprenta. En el proyecto de Ley sobre esta materia, de 23 de diciembre de 1835, se defendía con el siguiente argumento: Es cierto que la declaración anterior del jurado que ha de decidir si al delito acompañan circunstancias agravantes o atenuantes, y el mayor o menor número de los jueces de hecho que condenen el escrito, limitarán sobremanera la autoridad del tribunal; pero todavía el ancho límite que es necesario establecer entre el máximum o mínimum de las penas que han de castigar esta clase de delitos, dejan una grande facultad discrecional a los jueces, cuya inexperiencia e irreflexiva arbitrariedad pudieran desacreditar a una institución naciente que tanto conviene fortalecer.

Este estudio sobre la institución se basa en especial en la Ley Orgánica del Tribunal del Jurado, dado que se van a analizar las sentencias 
derivadas de los veredictos de los ciudadanos legos en Derecho. Se comienza con una explicación de su fundamento constitucional en el art. 125 de la Carta Magna, al permitir la participación de los ciudadanos en la Administración de Justicia, como instrumento democrático; la base legal para que este tribunal exista y la justificación que motiva el hecho de que el homicidio y el asesinato sean de su competencia, pormenorizado en la Exposición de Motivos de la propia LOTJ, fundamentado en la escasa complejidad que presenta la determinación de los hechos en estos tipos delictivos, lo que facilita la intervención de ciudadanos no expertos.

Aunque la regulación actual se deba a la Constitución de 1978, el jurado ya existe desde tiempos remotos, incluso en la legislación española. De esta forma, se exponen los antecedentes y la evolución del jurado en España durante los últimos siglos, desde su creación en 1820, con sus precedentes en normas que se ocupaban de otras materias como la Ley de Imprenta o la Ley de Enjuiciamiento Criminal, pasando por la Ley del Jurado de 1888, sus diversas derogaciones y su vigencia intermitente, hasta llegar a la actual Ley de 1995.

También analizaremos los distintos modelos de jurado y las principales diferencias entre el sistema puro o anglosajón, propio en países como Estados Unidos o Reino Unido, y el escabinado, vigente en numerosos países europeos, así como la comparación de las normas extranjeras con nuestro ordenamiento, con sus respectivas ventajas y sus inconvenientes, con especial atención al modelo seguido en España (anglosajón) y su distinción con el mismo modelo aplicado en otros estados, todo ello a través del estudio de los códigos de procedimiento penal extranjeros, otras leyes especiales en la materia y la doctrina de catedráticos y otros expertos en este ámbito procesal. 
Veremos la regulación vigente en cada una de las fases del procedimiento, qué delitos son de la competencia del jurado, cómo se forma, qué funciones tiene y qué extremos debe contener tanto el veredicto como la sentencia, relacionándolo también con la Ley de Enjuiciamiento Criminal. Se presta especial interés a la exigencia de motivación del veredicto, ya que es un requisito exclusivo de la normativa española.

Por último se procederá al análisis de las sentencias, de las que se han extraído doscientos treinta y cinco veredictos y, a través del programa estadístico SPSS (Statistical Pakcage for the Social Sciences), deduciremos los resultados en función de las sentencias de las Audiencias Provinciales que han sido recurridas en segunda instancia, así como desde la observación de otras fuentes como algunas estadísticas oficiales del propio Consejo General del Poder Judicial.

\subsection{Material utilizado y metodología de trabajo.}

Con el fin de estudiar ambos objetivos planteados, si en los juicios por homicidio y por asesinato, el jurado se inclina más hacia la culpabilidad o hacia la no culpabilidad de los presuntos autores de los hechos $\mathrm{y}$ compararlo con los casos en los que, tras el recurso, el tribunal profesional ha emitido un fallo en sentido contrario, hemos analizado un total de trescientas treinta y una sentencias, obtenidas de la base de datos del Centro de Documentación Judicial del Consejo General del Poder Judicial (CENDOJ), en los siguientes ámbitos: 


\subsection{1. Ámbito territorial.}

Circunscrito a la Comunidad Autónoma de Castilla y León, con la distribución que a continuación se detalla:

- 193 sentencias de las nueve Audiencias Provinciales con sede en Castilla y León (12 de Ávila, 44 de Burgos, 45 de León, 10 de Palencia, 17 de Salamanca, 13 de Segovia, 7 de Soria, 32 de Valladolid y 13 de Zamora).

- 99 sentencias del Tribunal Superior de Justicia de Castilla y León, en recurso de apelación.

- 39 sentencias del Tribunal Supremo que resuelven el recurso de casación de las anteriores.

\subsection{2. Ámbito material.}

Dentro de los once delitos que el art. 1 de la LOTJ atribuye a la competencia del Tribunal del Jurado, todas las sentencias analizadas son en casos de delitos contra las personas, en concreto, el homicidio y el asesinato. Se han elegido estos delitos por ser los más graves y en los que el jurado puede tener una predisposición mayor al castigo.

De esta forma, se observa si el veredicto es de culpabilidad y por tanto la sentencia correspondiente es condenatoria, o si es de inculpabilidad y la subsiguiente sentencia es absolutoria.

El análisis se realizará teniendo en cuenta las diferencias entre homicidios y asesinatos; entre veredicto de culpabilidad y de inculpabilidad, que dé lugar a la condena o absolución del encausado; la provincia en la que se ha cometido el hecho; y el sexo del acusado, este 
último con el fin de determinar una posible variación en la que quizás el jurado sea más severo con unos o con otros.

El apartado dedicado a los resultados se encuentra dividido en tres partes:

- Las variables mencionadas que afectan a los veredictos y las consiguientes sentencias de las Audiencias Provinciales.

- Las variables presentes en las sentencias del Tribunal Superior de Justicia, poniendo el énfasis en la resolución del recurso de apelación.

- Las variables recogidas en las sentencias del Tribunal Supremo, profundizando de igual forma en la resolución del recurso de casación.

\subsection{3. Ámbito temporal.}

Todos los veredictos y los fallos estudiados, tanto en primera instancia como las sentencias conocidas en los recursos, son desde la entrada en vigor de la Ley Orgánica del Tribunal del Jurado, el 23 de noviembre de 1995, hasta el año 2017 incluido.

Haremos hincapié en las sentencias en las que haya una variación en la condena del tribunal profesional cuando fallan los recursos, respecto al sentido del veredicto inicial del jurado en el ámbito de la Audiencia Provincial.

Para ser más precisos, no se tendrán en cuenta las modificaciones que no afectan a la función del jurado, como es estimar los recursos, total o parcialmente, respecto a una calificación jurídica, la responsabilidad civil, 
aplicación de distinta pena, etc., sino solamente aquellas anulaciones de sentencias que hagan referencia al cambio del veredicto. 


\section{PERSPECTIVA HISTÓRICO-JURÍDICA Y COMPARADA DE LOS DELITOS CONTRA LA VIDA.}

\subsection{Evolución de los delitos de homicidio y asesinato en la historia de los códigos penales españoles.}

Ya que, como se ha explicado en la introducción, los delitos objeto del estudio del análisis de los veredictos son el homicidio y el asesinato, a continuación, pasamos a exponer su regulación histórica y vigente dentro de nuestro sistema penal, así como en otros países de nuestro entorno.

Debido a su especial gravedad, estos delitos siempre han estado tipificados en todos los códigos penales españoles. Por este motivo, consideramos importante analizar en este apartado cómo han evolucionado estas figuras a lo largo de la historia penal española, adaptándose al momento social de cada época. Centramos este punto únicamente desde la etapa codificadora.

\subsubsection{El Código Penal de 1822.}

A lo largo de la primera mitad del siglo XIX, se empiezan a producir las grandes codificaciones legislativas, debido a la influencia del movimiento de la Ilustración. Como afirma Gabriela Cobo del Rosal ${ }^{1}$ esta fase es "el núcleo medular de todo el proceso de creación legislativa", por lo que es la referencia esencial para entender el actual sistema jurídico penal. El primer Código Penal Español fue promulgado en 1822, tras la aprobación de la Constitución de 1812, y con la influencia del Código francés de Napoleón

\footnotetext{
${ }^{1}$ Cobo del Rosal, G. (2012). "El proceso de elaboración del Código Penal de 1928”, en Anuario de historia del derecho español, nº 12, pág. 601.
} 
(1810). En este texto regía una política de prevención general, por el que las penas tienen como objetivo intimidar y disuadir de la comisión de un delito. Ha sido uno de los códigos más extensos, con 816 artículos, pero su vigencia no fue muy duradera, puesto que en 1823 fue derogada la legislación del Trienio Liberal (1820-1823).

Comenzaba con el homicidio regulado en la "Parte segunda. De los delitos contra los particulares", dentro del Título primero, que lleva por rúbrica "De los delitos contra las personas", Capítulo I "Del homicidio, envenenamiento, castración y aborto, y de los que incendian para matar" ${ }^{2}$ (arts. 605-641).

Distingue entre homicidio y asesinato y regula el primero, tanto en su modalidad de delito doloso como imprudente, en el art. 605: Los que maten á otra persona voluntariamente, con premeditación, y con intencion de matarla, no siendo por orden de autoridad legítima, sufrirán la pena de muerte. Es homicidio voluntario el cometido espontáneamente, á sabiendas, y con intencion de matar á una persona, siendo indiferente en este caso que el homicida dé la muerte á otra persona distinta de aquella á quien se propuso hacer el daño.

Este tipo de delitos contra la vida eran considerados de los más graves y por ese motivo se llegaban a castigar con la pena de muerte, al atentar contra el bien jurídico más importante y valioso del ser humano.

Como se analizará más adelante en el apartado dedicado a la legislación internacional, es objeto de debate la distinción o no entre las figuras del homicidio y del asesinato. En nuestro ordenamiento ha sido

\footnotetext{
${ }^{2}$ Código Penal Español de 1822. [en línea] [Disponible en http://www.cienciaspenales.net/portal/page/portal/IDP/Dosier/la\%20constitucion\%2018 12/codigoPenal1822.pdf].
} 
tradicionalmente regulado con dos tipos penales y así se mantiene en la actualidad.

En 1822, el homicidio aparece en los arts. 605 a 608 y el asesinato a partir del 609. Este requería unos elementos específicos, además de señalar a quien mataba a otra persona no solo voluntariamente, con premeditación y con intención de matarla. Dichos elementos eran los siguientes:

- En virtud de dones ó promesas que se les hayan hecho previamente.

- Con previa asechanza, ya aguardando á la persona asesinada, ó á la tenida en lugar suyo, en uno ó mas sitios para darle la muerte; ya observando la ocasion oportuna para embestirle; ya poniéndole espías ó algun tropiezo ó embarazo para facilitar la ejecucion; ya buscando auxiliadores para el mismo fin, ó ya empleando de antemano cualquier otro medio insidioso para sorprender á dicha persona y consumar el delito.

- Con alevosía ó á traicion y sobre seguro, ya sorprendiendo descuidada, dormida, indefensa ó desapercibida á la persona asesinada, ya llevándola con engaño ó perfidia, ó privándola antes de la razon, de las fuerzas, de las armas ó de cualquier otro auxilio para facilitar el asesinato; ya empeñándola en una riña ó pelea, provocada por el asesino con ventaja conocida de parte de este; ó ya usando de cualquier otro artificio para cometer el delito con seguridad ó sin riesgo del agresor, ó para quitar la defensa al acometido.

- Con sustancias ó bebidas venenosas ó nocivas que á sabiendas se hayan aplicado á la persona asesinada.

- Con la esplosion ó ruina de materiales preparados para el asesinato; ó con fuego. 
- Con tormentos ó con algun acto de ferocidad ó crueldad, bien se cause la muerte por alguno de estos actos, bien se cometa alguno de ellos con el cadaver despues de darle la muerte.

- Con el fin de cometer cualquiera otro delito, ó con el de castigar la resistencia que en la ejecucion de este oponga la persona asesinada, ó con el de impedir que estorbe ó embarace la misma ejecucion, ó que lo descubra ó detenga al delincuente despues de cometido.

Por lo tanto, existían múltiples circunstancias que calificaban el asesinato, más que ahora. Varias continúan regulándose en el código actual, como son: precio, promesa o recompensa (llamado entonces dones $o$ promesas); alevosía (que figura tanto con esa denominación como en la característica con previa asechanza $a^{3}$ ), bastante más explicada que en la actualidad, pero que solo se contempla para el delito de asesinato y no como agravante genérica; y lo que se podría entender como ensañamiento (tormentos o actos de ferocidad o crueldad), con dos diferencias respecto a la legislación vigente, ya que, por una parte, no exige que sean innecesarios, como sí sucede ahora y, por otra, contempla la posibilidad de realizar esos actos sobre el cadáver, requisito que la ley de 1995 no exige, porque considera el ensañamiento como un sufrimiento añadido a la víctima, para lo que es necesario que esté viva.

Además de estas tres circunstancias que han llegado hasta nuestros días, se apreciaban otras como sustancias venenosas, explosión y fuego. Estas últimas se mantuvieron vigentes hasta su supresión en 1995, ya que el texto refundido de 1973 también calificaba el asesinato por medio de

\footnotetext{
3 Esta circunstancia se introduce por influencia del derecho europeo y solamente aparece en el Código Penal de 1822. Martos Núñez, J. A. (2017). El delito de asesinato. Análisis de la L.O. 1/2015 de 30 de marzo, de Reforma del Código Penal. Barcelona: Bosch, pág. 15.
} 
inundación, veneno, incendio o explosivo ${ }^{4}$ lo que después se derogó en el código actual $^{5}$, al considerarlas como incluidas en la alevosía 6 .

Asimismo, se entendía en esta época que al concurrir cualquiera de las circunstancias calificadoras expuestas, la premeditación estaba implícita $^{7}$ y, por tanto, formaba parte del homicidio, no como una característica calificadora del asesinato, lo que sí ha sucedido posteriormente. Así, el art. 606 exponía lo siguiente: La premeditacion ó el designio de cometer la accion, formado antes de cometerla, existe en el homicidio voluntario: Primero: aunque el previo designio de cometerlo se haya formado con alguna condicion ó con alguna diferencia en cuanto al modo de ejecutar el delito. Segundo: aunque se haya formado el designio con relacion á otra persona ó á persona indeterminada. Tercero: aunque antes del homicidio se haya formado designio, no precisamente de matar, sino de maltratar á una persona determinada ó indeterminada, siempre que al tiempo de ejecutar el delito se unan en el reo la espontaneidad y la intencion actual de dar la muerte.

\footnotetext{
${ }^{4}$ Art. $406.3^{\text {a }}$ del Decreto 3096/1973, de 14 de septiembre.

${ }^{5}$ La supresión de esta circunstancia es la respuesta a un sector doctrinal, basándose en que la utilización de esos medios "implica adicionalmente un peligro para la vida y la integridad de otros individuos distintos de aquel o de aquellos a quienes se quiera matar, pero como la utilización de tales medios está configurada ya en el Código penal como un delito autónomo (daños, incendio, estragos), entones lo que procede en tales casos es apreciar el correspondiente concurso de delitos entre el homicidio y el delito de daños, incendio o estragos". Gracia Martín, L. (2007). Los delitos de homicidio y de asesinato en el Código Penal Español. Doctrina y jurisprudencia. Valencia: Tirant lo Blanch, pág. 173.

${ }^{6} \mathrm{Su}$ fundamento era "el empleo de medios susceptibles de ocasionar grandes estragos, con la capacidad de creación de riesgos añadidos para otros bienes jurídicos. Como medio que tiende a asegurar la ejecución del delito con anulación de las facultades de defensa de la víctima, ya puede ser valorados como expresión concreta de la alevosía para conformar el delito de asesinato". Morales Prats, F., en Quintero Olivares, G. (dir.); Morales Prats, F. (coord.). (2016). Comentarios a la parte especial del Derecho Penal. Navarra: Aranzadi (10ª ed.), pág. 58.

${ }^{7}$ Art. 610 CP 1822.
} 
El código mencionaba el parricidio ${ }^{8}$ de manera expresa, como otra modalidad más del homicidio. Era parricida quien mataba a sus padres, abuelos o cualquier otro ascendiente en línea recta, y se castigaba con la pena capital por ser parricida e infame ${ }^{9}$. En un artículo diferente, el 612, se contempla el asesinato de otros parientes distintos a los de la línea ascendente.

Existían también los llamados crímenes de honor, actos más o menos justificados que no eran castigados con la pena de muerte y que consistían en matar a una hija, nieta u otro tipo de descendiente en línea recta cuando era sorprendida en determinados actos deshonestos. Únicamente eran penados con arresto de seis meses a dos años y destierro de dos a seis años ${ }^{10}$. Si en estos supuestos la víctima era una hermana, una nuera o el hombre con quien realizan los actos deshonestos, la pena era mayor, reclusión de dos a cinco años -que con alguna circunstancia más podía llegar a ocho- y destierro de cuatro a ocho -pena que podía llegar hasta diez- ${ }^{11}$. Es decir, que si la deshonra provenía de la hija, la pena era más leve. Lógicamente, este tipo delictivo desapareció más tarde.

Asimismo se contemplaban circunstancias eximentes, como la legítima defensa, bastante más detallada que en la actualidad, ya que el código enumera en qué supuestos se aplica: defender la vida, la propiedad, la libertad, la familia, etc. Tipificaba también la figura del homicidio involuntario, que definía en los arts. 626 y ss., como matar sin intención de hacerlo, por descuido, imprevisión, error, etc. Y en el art. 625 castigaba a los padres o abuelos que provocaban la muerte de manera involuntaria en

\footnotetext{
${ }^{8}$ Art. 613 .

${ }^{9}$ Se consideraba un delito más grave por su propia naturaleza, al atentar contra los propios ascendientes $\mathrm{u}$ otros familiares.

${ }^{10}$ Art. 619.

${ }^{11}$ Art. 620. 
un exceso al corregir a sus descendientes, como reos de homicidio involuntario cometido por ligereza.

\subsubsection{El Código Penal de 1848.}

Este código, compuesto por 526 artículos, se aprueba después de presentar tres proyectos $(1830,1831$ y 1834) y más tarde fue reformado en 1850 . Es una ley más severa, influida por el código anterior. Esta agravación se veía justificada porque, con el movimiento ilustrado, se había dado más margen al arbitrio judicial y se consideraba que la norma se había suavizado, lo que a su vez, generaba cierta desconfianza en los magistrados, debido a los constantes cambios de régimen político durante la primera mitad del siglo.

Ya en 1848 se plantea una estructura diferente a la del código anterior y esta perdurará hasta la reforma de 2015. Divide el texto en tres libros -ya con esa denominación-, el primero sobre las disposiciones generales, las penas, las personas responsables, etc.; el segundo sobre los delitos y el tercero sobre las faltas ${ }^{12}$. En las penas establecidas se refleja un claro componente retributivo aunque también presenta una finalidad de prevención general. Asimismo introduce el sistema de clasificación de las penas que hemos seguido hasta la actualidad en graves, menos graves y faltas, hasta la desaparición de estas últimas.

El homicidio, igual que en el código anterior y en el vigente, figuraba en el Libro II "Delitos y sus penas", dentro del Título IX “Delitos contra las personas", Capítulo I "Homicidio" (arts. 332-335). Este código ${ }^{13}$ organiza

\footnotetext{
12 Aunque esa misma estructura se ha mantenido hasta el código de 1995, con la reforma que entró en vigor el 1 de julio de 2015, mediante la LO 1/2015, de 30 de marzo, se han suprimido las faltas y por lo tanto el libro III.

${ }^{13}$ Código Penal Español de 1848 [en línea] [Disponible en http://fama2.us.es/fde/codigoPenal1848.pdf].
} 
los delitos de forma separada y dedica distintos capítulos al aborto y el infanticidio.

Su estructura y su redacción son mucho más precisas. En el Cap. I se regula el delito de parricidio ${ }^{14}$, castigado, si concurre premeditación o ensañamiento, con pena capital $\mathrm{y}$, en los demás supuestos, con cadena perpetua. Los sujetos pasivos ya no son únicamente los ascendientes, sino que ahora figuran todos los parientes en el mismo artículo como víctimas de este delito: se amplía a los descendientes, el cónyuge y los parientes legales o por adopción pero no incluye a los ascendientes o descendientes ilegítimos en segundo o superior grado ni a los colaterales ${ }^{15}$.

El homicidio y el asesinato se regulaban de manera conjunta en el art. 333, aunque no aparecían con ese nombre. Como explica Alonso Álamo y veremos más adelante, "el nomen iuris sería introducido por el Código penal de 1870 que habla ya de «asesinato»"16. En 1848, constituía asesinato el homicidio que en la práctica se llamó "cualificado" y se dio el nombre de homicidio "simple" al que no reunía las circunstancias específicas que lo agravaban ${ }^{17}$.

Las circunstancias del asesinato, castigado desde la cadena perpetua a la pena de muerte, figuraban en el apartado primero y se redujeron a cinco respecto a la norma precedente, las mismas que se mantendrán hasta 1995:

\footnotetext{
${ }^{14}$ Art. 332 del RD 19 de marzo de 1848.

15 Iñesta Pastor, E. (2011). El Código Penal Español de 1848. Valencia: Tirant, pág. 684.

${ }^{16}$ Alonso Álamo, M. (2015). "La reforma del homicidio doloso y del asesinato por LO 1/2015", en Cuadernos de política criminal, n 117, pág. 9.

${ }^{17}$ Viada y Vilaseca, S. (1877). Código Penal reformado, de 1879. Madrid: Eduardo Martínez, págs. 10 y 11.
} 
- Alevosía ${ }^{18}$, que ya aparece como circunstancia agravante genérica y la define como obrar a traición y sobre seguro. (Art. 10.2 ${ }^{\mathrm{a}}$ ).

- Precio o promesa remuneratoria.

- Por medio de inundación, incendio o veneno.

- Con premeditación.

- Ensañamiento ${ }^{19}$, que en este código sí se considera como un aumento del dolor de la víctima, de manera deliberada e inhumana ${ }^{20}$, como lo entendemos en la actualidad.

El segundo apartado contemplaba lo que interpretamos como el delito de homicidio, ya que el legislador se refiere a estos hechos en "cualquier otro caso", y lo castiga con pena de reclusión temporal (de 12 a 20 años). Es una pena menor y no especifica más circunstancias, ya que se limita a definir la acción de "matar a otro", de manera general, siempre que no esté comprendido en el artículo del parricidio, delito que sí define expresamente. Este primer capítulo era mucho más breve que el redactado en el código de 1822 y finalizaba con el castigo para quien prestase auxilio a otra persona para que se suicidara.

\footnotetext{
${ }^{18}$ Este Código no reproduce la figura del acecho de manera separada y se creó una discusión doctrinal sobre si la expresión a traición y sobre seguro exigía que se produjeran ambas o no. Altés Martí, M. Á. (1982). La alevosía: estudio de determinados aspectos de la agravante del $n^{o} 1$ del Art. 10 del Código penal. Valencia: Universidad de Valencia, págs. 24 y 25.

19 Hernández de la Rúa considera que "Por una equivocación lamentable se ha calificado de ensañamiento cualquier acto, de crueldad o barbaridad de parte del agresor, olvidando la definición que del ensañamiento da el artículo. Si no concurren reunidas las circunstancias de herir con inhumanidad para aumentar el dolor, y de que preceda la deliberación, no hay ensañamiento para los efectos del art. 333, será solamente circunstancia agravante”. Hernández de la Rúa, V. (1859). Código Penal Reformado. Madrid, pág. 204.

${ }^{20}$ Existe en este código una diferencia entre la agravante general, más amplia, que habla de males innecesarios, y la específica del asesinato, que exige que el aumento del dolor sea de forma inhumana. En los dos supuestos se requiere que el acto sea deliberado. Alonso Álamo, M. (2015). El ensañamiento. Granada: Comares, pág. 10.
} 
En el Capítulo II se regulaba el delito de infanticidio, que el código anterior castigaba dentro del homicidio entre parientes y no como un delito sui generis, debido a la importancia social que tenía la honra familiar ${ }^{21}$. En este Código de 1848 se sancionaba, en el art. 336, a la madre que por ocultar su deshonra matare al hijo que no haya cumplido tres días, con la pena de prisión menor (de cuatro a seis años). Además de la madre, también los abuelos maternos podían ser sujetos activos y, en ese caso, la pena se agravaba a prisión mayor (de siete a doce años). Solamente la madre y los abuelos maternos podían cometer este delito porque tenía una motivación específica que lo determinaba, el hecho de ocultar la deshonra, que no se presumía y debía probarse (especialmente en el caso de los abuelos) y esa misma razón es la que justifica que la pena sea atenuada si la comparamos con el homicidio, y más si la autora es la madre. Al margen de estos dos supuestos, matar a un recién nacido se castigaba como homicidio ${ }^{22}$.

\subsubsection{El Código Penal de 1870.}

Con la aprobación de la Constitución en 1869, se aspira a suavizar las penas y humanizar el código penal. El homicidio sigue apareciendo en el Libro II "Delitos y sus penas", dentro del Título III "Delitos contra las personas" ${ }^{, 23}$, regulado de forma muy parecida a la norma precedente. Los diversos tipos delictivos contra la vida se redactan separados por capítulos y con una minuciosa descripción. Como señaló Alejandro Groizard, esta clasificación no sigue un criterio científico sino una finalidad práctica.

\footnotetext{
${ }^{21}$ Iñesta Pastor, op. cit., pág. 689.

${ }^{22}$ Así lo establecía el propio artículo 336: Fuera de estos casos, el que matare a un recién nacido incurrirá en las penas del homicidio.

${ }^{23}$ Código Penal Español de 1870 [en línea] [Disponible en http://www.boe.es/datos/pdfs/BOE//1870/243/A00009-00023.pdf]. Compuesto por 626 artículos.
} 
Afirma que "este objeto podría haberse obtenido con una división más reducida, que no se alejase tanto de lo que la razón aconseja, atendida la índole de los derechos lesionados" 24 .

En esta ocasión, tanto el homicidio como el asesinato sí van a denominarse como tales. El título sigue la siguiente estructura:

- Capítulo I (art. 417) el parricidio: por su gravedad, de nuevo es el primer delito que aparece e incluye a los mismos sujetos pasivos que en 1848 (ascendientes, descendientes o cónyuge), castigado con la pena de cadena perpetua a muerte. No distingue los supuestos, ya que antes, en determinadas circunstancias, se aplicaba solo la pena capital.

- Capítulo II (art. 418) el asesinato $^{25}$ : con la concurrencia de las mismas cinco características mencionadas en la ley anterior, aunque aquí la alevosía es exclusiva de los delitos contra las personas y ya se hace referencia al empleo de medios modos o formas en la ejecución (art. 10.2 ). La norma define la alevosía, de manera que se subsanan los problemas interpretativos del anterior Código Penal en cuanto a su concepto ${ }^{26}$.

El asesinato se castigaba con la pena de cadena temporal $^{27}$ en su grado máximo a muerte. Bastaba una de las circunstancias para calificar el delito como asesinato y, si había más de una, se consideraban como circunstancias agravantes generales.

\footnotetext{
${ }^{24}$ Groizard y Gómez de la Serna, A. (1902). El Código penal de 1870: concordado y comentado (Tomo IV). Madrid: Establecimiento Tipográfico de los Hijos de J. A. García ( $2^{a}$ ed.), pág. 361.

${ }^{25}$ Viada y Vilaseca afirma que, a diferencia de la regulación anterior, "existiendo en nuestra lengua la palabra asesinato, que significa muerte alevosa, tenemos por acertada su adopción en el lenguaje jurídico penal”. Viada y Vilaseca, op. cit., págs. 10 y 11.

${ }^{26}$ Altés Martí, op. cit., pág. 28.

${ }^{27} 12$ años y un día a 20 años (art. 29).
} 
- Capítulo III (arts. 419-421) el homicidio: el Código de 1848 no hacía una referencia manifiesta a los términos "homicidio" ni "asesinato", sino que simplemente concretaba la pena aplicable "en cualquier otro caso" que no fuera parricidio o en el que no concurrieran las circunstancias que hoy califican el asesinato. En 1870 la diferencia entre ambos tipos es evidente. Aunque la descripción del hecho es similar, el homicidio tiene artículo propio y se menciona expresamente: es reo de homicidio el que sin estar comprendido en el art. 417 matare á otro, no concurriendo alguna de las circunstancias numeradas en el artículo anterior. La pena es de reclusión temporal (de doce años y un día a veinte años, algo más alta que en la actualidad), por lo que, una vez más, comprobamos cómo se mantiene esa distinción al dotar al asesinato de una especial gravedad, ya que el hecho podía llegar a castigarse con la pena de muerte, no así el homicidio, al que únicamente se le aplicó la pena capital en el primer código de 1822. El auxilio al suicidio (art. 421) se contempla con la misma descripción y pena que en 1848 (reclusión temporal).

- Capítulo V (art. 424) el infanticidio: como sucede con el parricidio, la figura nuevamente aparece de forma expresa, con la misma descripción del supuesto y en idéntico orden, aunque la pena varía, de prisión menor en 1848, a prisión correccional (seis meses y un día a seis años, con un mínimo bastante menor) para la madre y se permanece la de prisión mayor (seis años y un día a doce años) para los abuelos maternos. Los sujetos pasivos no incluidos en estos casos son considerados como parricidas o asesinos.

Según Saldaña, este código sigue una fórmula de clasificación de la infracción que distingue entre la clasificación criminal, que se basa en la 
gravedad del delito; y la clasificación penal, fundamentada en la gravedad de la pena ${ }^{28}$.

\subsubsection{El Código Penal de 1928.}

Aportó una gran novedad, la inclusión de una Exposición de motivos denominada simplemente "Exposición"-, que justifica la pretensión de buscar no una ley sabia para pueblos del porvenir, sino una ley comprensible para todos y fácilmente aplicable en la España del tiempo en que vivimos; que signifique un progreso con relación al pasado y deje acceso a los progresos futuros ${ }^{29}$. Curiosamente, expresa la intención de no tener que alterar el nuevo texto a corto plazo, a pesar de que la vigencia de este código fue muy breve. Prescinde de las penas perpetuas y ya no contempla ningún delito, por grave que sea, para el que la única pena aplicable sea la pena de muerte, ni siquiera el asesinato. La Exposición de Motivos indica que no es forzoso imponer ésta cuando en el reo de delitos que la tengan señalada concurra una sola circunstancia agravante. También señala que se logrará mayor individualización de las penas, procurando que no se imponga la misma pena por todos los delitos iguales, ya que todos los delincuentes no son iguales, ni lo son las circunstancias en que los delitos se cometen ${ }^{30}$.

Los delitos contra la vida aparecían también en el Libro II "Delitos y sus penas", dentro del Título VII "Delitos contra la vida, la integridad corporal y la salud pública de las personas" ${ }^{\text {31 }}$. Aunque presentaba idéntica

\footnotetext{
${ }^{28}$ Saldaña, Q. (1920). Comentarios al Código Penal de 1870 (vol. I). Madrid: Reus, pág. 469.

${ }_{29}$ Real Decreto-Ley núm. 1596.

${ }^{30}$ Código Penal de 1928. Madrid: Calleja.

${ }^{31}$ Código Penal Español de 1928 [en línea] [Disponible en

https://www.boe.es/datos/pdfs/BOE/1928/257/A01450-01526.pdf].
} 
estructura, se modificó el orden y el homicidio pasó a ser el primero. $\mathrm{Su}$ disposición se conformaba como se expone a continuación:

- Capítulo I (arts. 515 a 518), el homicidio: se rebajó el límite mínimo de la pena, que en este código contempla entre los ocho y los veinte años de prisión. Por otra parte, el auxilio al suicidio se castiga entre cuatro y ocho años de prisión $\mathrm{y}$, en caso de provocarse la muerte, puede llegar hasta la pena de quince años de prisión.

- Capítulo II (arts. 519-520), el asesinato: penado de veinte años de reclusión a muerte. Además de las cinco circunstancias calificadoras que figuraban en el Código de $1870^{32}$, se amplió el número de supuestos:

- Ejecutar el hecho para preparar, facilitar, consumar y ocultar un delito, o para impedir el descubrimiento de otro, circunstancia en la que no era necesario que dicho delito fuese cometido por el homicida sino que se apreciaba cuando el delito era imputable a otros ${ }^{33}$.

- Por impulso de perversidad brutal. Esta figura fue adaptada del derecho italiano y se refería al homicidio sin causa que lo explicara o cuando esta era desproporcionada ${ }^{34}$.

- Se añaden sumersión y naufragio ${ }^{35}$, además de incluir una cláusula abierta, cualquier otro medio capaz de poner en

\footnotetext{
${ }^{32}$ Entre ellos, mantiene el ensañamiento pero en esta ocasión cambia el requisito de que el aumento del dolor sea "deliberado" para pasar a la exigencia de que sea "innecesario", como en la agravante general. Alonso Álamo (2015). El ensañamiento, op. cit., pág. 12.

${ }^{33}$ Cuello Calón, E. (1930). El nuevo Código Penal Español. Barcelona: Bosch, pág. 557.

${ }^{34}$ Ibid., pág. 561.

35 Se agrava no solo por el medio empleado sino por la especial peligrosidad que conlleva la utilización de dichos medios. Ibid., pág. 569.
} 
peligro la vida, la integridad corporal o la salud de otras personas.

- Capítulo III (arts. 521-523), parricidio: mantiene quién es el sujeto pasivo y modifica la pena, que deja de tener el mínimo de cadena perpetua y se rebaja a veinticinco años de reclusión, mientras que el máximo continuaba siendo la pena de muerte. El resto de parientes se incluyen en este tipo penal, como un supuesto atenuado y así, se considera parricida al que mate a los hermanos, padres adoptivos, las personas que hayan criado al culpable, hijos adoptivos, los que hayan sido criados por el culpable y afines en línea recta. La reclusión en estos casos es de dieciocho a veinte años.

Además, establece una novedad en la que la pena es más leve, para quien mata o hiere a su cónyuge si lo sorprende en actos de adulterio o a quien esté con él, salvo el caso de que, aunque fuera tácitamente, lo hubiera consentido. Esta modalidad estará vigente durante un largo periodo de tiempo.

- Capítulo IV (art. 524), infanticidio: modifica las penas con una significativa atenuación. En el caso de la madre, pasa a ser de prisión entre seis meses y cuatro años, y de cuatro a ocho años si el acto es cometido por los abuelos.

\subsubsection{El Código Penal de 1932.}

Durante la Segunda República Española, fue abolido el Código de 1928 y se recuperó el de 1870, aunque con modificaciones para adaptarlo a la Constitución de 1931. Tomando como base el Código de 1870, se aprobó uno nuevo en 1932, cuya Exposición de Motivos justifica la necesidad de reforma y la pretensión de humanizarlo. Con este objetivo, algunas de las 
medidas que se adoptaron fueron la derogación, tanto de la pena de muerte como de las perpetuas, el aumento del número de circunstancias eximentes y atenuantes y la reducción de las agravantes. Los momentos en los que se elimina la pena de muerte coinciden con la debilitación de la autonomía del delito de asesinato. En 1928 tenía un apartado independiente y en 1932 pasa a regularse dentro del homicidio, como en la legislación vigente ${ }^{36}$.

Los "Delitos contra la vida y la integridad corporal" se regulan también en Libro II "Delitos y sus penas", dentro del Título IX $^{37}$, dividido únicamente en los tres capítulos -ya que el tercero regula el aborto-, por lo que algunos de los hechos punibles que antes figuraban en capítulos distintos, ahora se entienden incluidos dentro del homicidio:

- Capítulo I: el homicidio, que abarca todas las modalidades. De este modo, castiga:

- el parricidio (art. 411), con pena de reclusión mayor (de veinte años y un día a treinta años);

- el asesinato (art. 412), con pena de reclusión menor en su grado máximo (de diecisiete años, cuatro meses y un día a veinte años) a reclusión mayor. Aunque aparezcan dentro del mismo capítulo, el asesinato sigue siendo una figura distinta del homicidio, como se comprueba al tener su propia denominación ${ }^{38}$. Las circunstancias calificadoras se reducen de nuevo a cinco, como antes del Código de 1928 y la pena capital ha sido derogada;

\footnotetext{
${ }^{36}$ Mapelli Caffarena, B. (1988). "El dolo eventual en el asesinato", en Anuario de derecho penal y ciencias penales, Tomo 41, Fasc/Mes 2, pág. 434.

${ }^{37}$ Código Penal Español de 1932 [en línea] [Disponible en http://www.boe.es/datos/pdfs/BOE//1932/310/A00818-00856.pdf].

${ }^{38}$ López-Rey, M. y Álvarez-Valdés, F. (1933). El nuevo Código Penal. Madrid: Revista de Derecho Privado, pág. 377.
} 
- el homicidio simple (art. 413), con pena de reclusión menor (de doce años y un día a veinte años);

- el auxilio y la inducción al suicidio (art. 415), con pena de prisión mayor (de seis años y un día a doce años) y, si causa la muerte, de reclusión menor.

- Capítulo II (art. 416): el infanticidio, que continúa siendo una figura privilegiada por razones de culpabilidad, ya que si lo fuera por motivos de antijuridicidad, "se tendría que penar más gravemente la muerte de un niño" ${ }^{39}$. Se unificaron las penas para la madre y los abuelos, todos ellos castigados con prisión menor en sus grados mínimo y medio (de doce años y un día a diecisiete años y cuatro meses). El sujeto pasivo de este delito era el hijo recién nacido.

2.1.6. El Código Penal de $1944^{40}$ y la reforma del texto refundido de $1973^{41}$.

Este código recuperó la pena de muerte, aunque no como única pena sino como límite máximo. Permanece la misma estructura con tres capítulos y de nuevo contempla el homicidio en el Libro II "Delitos y sus penas", Título VIII "Delitos contra las personas":

- Capítulo I: el homicidio: que englobaba todos tipos con su denominación:

- Parricidio (art. 405), sancionado con pena de reclusión mayor (de veinte años y un día a treinta años) a muerte.

\footnotetext{
39 Ibid., pág. 382.

${ }^{40}$ Decreto de 23 de diciembre de 1944. Edición Oficial publicada por el Ministerio de Justicia. Madrid.

${ }^{41}$ Decreto 3096/1973, de 14 de septiembre, [en línea] [Disponible en https://www.boe.es/buscar/doc.php?id=BOE-A-1973-1715].
} 
- Asesinato (art. 406), con las mismas cinco circunstancias de las legislaciones anteriores y pena de reclusión mayor a muerte. Posteriormente se reformará a solamente reclusión mayor en su grado máximo (de veintiséis años, ocho meses y un día a treinta años).

- Homicidio (art. 407), castigado con pena de reclusión menor (de doce años y un día a veinte años).

- Auxilio o inducción al suicidio (art. 409), con pena de prisión mayor (de seis años y un día a doce años) y, si se provoca la muerte, pena de reclusión menor.

- Capítulo II: infanticidio (art. 410), como en el código anterior, se refiere al recién nacido como sujeto pasivo y la pena es de prisión menor (de seis meses y un día a seis años).

En 1973 se aprobó un texto refundido de este código, que tuvo vigencia hasta el actual de 1995. Hasta la fecha de su aprobación, sufrió numerosos reformas y la más importante llegó en 1983, a través de la LO 8/1983, de 25 de junio, de reforma urgente y parcial del Código Penal. Esta norma, entre otras cuestiones, derogó la pena de muerte, para adaptar el precepto a la Constitución de 1978, y mantuvo el resto de penas señaladas para los delitos contra la vida.

\subsubsection{El Código Penal de 1995.}

El análisis de los delitos contra la vida en el código vigente es objeto del siguiente apartado de esta tesis. Sin embargo, para terminar este apunte histórico, hay que indicar que, para adaptar la legislación penal a la Constitución de 1978, se realizó una reforma en profundidad, iniciada con la mencionada de 1983 y que culmina en la norma actual. El nuevo texto 
mantiene la misma estructura de los tres libros -hasta 2015, momento en el que se deroga el Libro III "Faltas y sus penas"-. Ya a través de una Ley Orgánica, como exige la Carta Magna, desaparece la denominación de las penas reclusión mayor, menor, prisión mayor, menor, etc. y se concreta en cada delito el margen de años que comprende la pena, por lo que tampoco existe, como sí había antes, una tabla explicativa con las distintas graduaciones de las penas en grado mínimo, medio y máximo.

Otra de las modificaciones es la exclusión de los delitos de parricidio $^{42}$ y de infanticidio, considerados desde entonces como homicidio simple o asesinato, si concurren las circunstancias que lo califican, que se reducen de cinco a tres -vuelven a aumentar a cuatro con la reforma de 2015-, y a los que se les puede aplicar la circunstancia mixta de parentesco $^{43}$.

Para Torío ${ }^{44}$, el parricidio "no requiere una acción objetivamente peligrosa diferente de la propia del homicidio simple" ni implica un "ataque más intenso al bien jurídico, puesto que la lesión de la vida humana no es graduable". Tampoco "ataca a bienes jurídicos plurales, como la vida y el orden familiar", por lo tanto no es necesario que el orden de la familia

\footnotetext{
${ }^{42}$ Bernardo del Rosal Blasco dice que es un acierto dejar el parentesco como una circunstancia de agravación general donde tenga sentido que sea así, ya que si se configura como una característica de culpabilidad, el legislador establece una presunción iuris et de iure de una culpabilidad más grave y considera que esto debería acreditarse a lo largo de un proceso penal a través de las pruebas que admiten prueba en contrario y no limitarse a comprobar el vínculo familiar. Del Rosal Blasco, B. (1992). "Política criminal de los delitos contra la vida humana independiente en el proyecto de Código Penal de 1922”, en Anales de la Universidad de Alicante, n .7, págs. 133-146. Facultad de Derecho.

${ }^{43}$ Anteriormente se regulaba en el art. 11 del CP de 1973: Es circunstancia que atenúa o agrava la responsabilidad, según la naturaleza, los motivos y los efectos del delito, ser el agraviado cónyuge o ascendiente, descendiente, hermano legítimo, natural o adoptivo, o afin en los mismos grados del ofensor.

44 Torío López, Á. (1983). "Estudio de la reforma de los delitos contra la vida (parricidio-asesinato)", en Rodríguez Devesa, J. (coord.), Repercusiones de la Constitución en el Derecho penal. Bilbao: Universidad de Deusto, pág. 87.
} 
requiera una intervención penal en ese sentido. Cabe destacar, que el Proyecto de 1994 sí incluía el parricidio y el conyugicidio, como casos de homicidio cualificado, pero posteriormente no se introdujeron estas figuras en la redacción final ${ }^{45}$.

A continuación se expone una tabla con la comparación de las penas en los distintos códigos penales de la historia de España, para observar mejor su evolución:

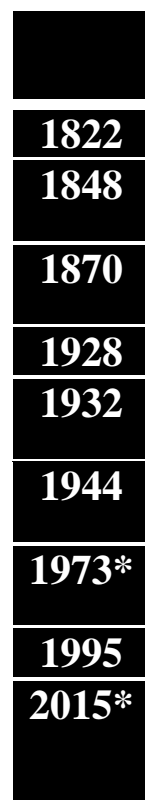

\begin{tabular}{|c|c|c|c|c|}
\hline Homicidio & Asesinato & Parricidio & \multicolumn{2}{|c|}{$\begin{array}{l}\text { Infanticidio } \\
\text { Madre/abuelos }\end{array}$} \\
\hline Pena de muerte & Pena de muerte & Pena de muerte & & \\
\hline 12 a 20 años & $\begin{array}{l}\text { Cadena perpetua a pena de } \\
\text { muerte }\end{array}$ & $\begin{array}{c}\text { Cadena perpetua a pena } \\
\text { de muerte }\end{array}$ & 4 a 6 años & 7 a 12 años \\
\hline 12 años y 1 día a 20 años & $\begin{array}{c}12 \text { años y } 1 \text { día-20 años / } \\
\text { pena de muerte }\end{array}$ & $\begin{array}{l}\text { Cadena perpetua a pena } \\
\text { de muerte }\end{array}$ & $\begin{array}{l}6 \text { meses y } \\
1 \text { día- } 6 \text { a. }\end{array}$ & $\begin{array}{l}6 \text { años y } 1 \\
\text { día-12 a. }\end{array}$ \\
\hline 8 a 20 años & 20 años a pena de muerte & 25 años a pena de muerte & 6 m. -4 a. & 4-8 años \\
\hline 12 años y 1 día a 20 años & $\begin{array}{l}17 \text { años, } 4 \text { meses y } 1 \text { día a } \\
30 \text { años }\end{array}$ & 20 años y 1 día a 30 años & $\begin{array}{r}12 \text { años y } \\
\text { y } 4\end{array}$ & $\begin{array}{l}\text { día-17 años } \\
\text { eses }\end{array}$ \\
\hline 12 años y 1 día a 20 años & $\begin{array}{c}20 \text { años y } 1 \text { día a } 30 \text { años / } \\
\text { muerte }\end{array}$ & 20 años y 1 día a 30 años & 6 meses y & día a 6 años \\
\hline 12 años y 1 día a 20 años & $\begin{array}{l}26 \text { años, } 8 \text { meses y } 1 \text { día a } \\
30 \text { años }\end{array}$ & $\begin{array}{l}20 \text { años y } 1 \text { día } \\
\text { a } 30 \text { años }^{46}\end{array}$ & 6 meses y & día a 6 años \\
\hline 10 a 15 años & 15 a 20 años & & & \\
\hline 10 a 15 años & $\begin{array}{c}15 \text { a } 25 \text { años / } \\
\text { prisión permanente } \\
\text { revisable }\end{array}$ & & & \\
\hline
\end{tabular}

Tabla 01. Evolución de las penas del homicidio y el asesinato.

Fuente: elaboración propia.

*Los textos de 1973 y 2015 no son Códigos Penales nuevos pero se incluyen en la tabla porque sí supusieron una modificación en las penas de los delitos contra la vida.

A través de esta tabla, podemos comprobar lo semejantes que han sido las penas desde el Código de 1870 hasta el de 1995, sobre todo, en lo referente al homicidio y el asesinato y cómo se ha atenuado progresivamente la pena para el parricidio y en especial la del infanticidio,

\footnotetext{
${ }^{45}$ Sanz Morán (1995), op. cit., pág. 817.

${ }^{46}$ La pena de muerte ya no se aplicaba al delito de homicidio. Se mantuvo como máximo para el asesinato y el parricidio, con el límite mínimo de reclusión mayor (la pena indicada en la tabla) y fue abolida por la Constitución en 1978.
} 
hasta que estas dos últimas figuras desaparecieron como tales y ahora se incluyen dentro del homicidio o del asesinato. La mayor diferencia la encontramos en el primer Código de 1822, que castigaba con la pena capital todos los delitos contra la vida, sin posibilidad de aplicación de otra pena distinta, ni siquiera para el supuesto de homicidio simple. Posteriormente, la legislación se ha ido adaptando al contexto histórico y social y se ha desarrollado una política criminal acorde a cada momento, coincidiendo en algunas ocasiones con la aparición de textos constitucionales que han influido en la legislación penal.

Siguiendo a Alonso Álamo, por una parte, la tendencia legislativa respecto al delito de asesinato ha sido simplificadora pero, por otra, "la tendencia de la jurisprudencia a interpretar ampliamente la alevosía ha constituido un indudable freno a la limitación del ámbito del asesinato posibilitando que este delito se siga presentando ante los ojos de la colectividad como un delito especialmente grave que concurre en un elevado número de los casos en que se mata a otro"47.

\subsection{Derecho comparado.}

Como hemos visto, el delito de homicidio se considera de tal gravedad que siempre ha sido castigado con las penas más graves, hasta la actualidad, ya que la prisión permanente revisable solo se impone en algunos casos de asesinato y no cabe aplicarla a ningún otro delito.

A diferencia de otros tipos penales, que, en función del país y del contexto histórico y social, se consideran o no como delito, los ataques contra la vida se castigan en todos los ordenamientos jurídicos, igual que

${ }^{47}$ Alonso Álamo, M. (2015). “La reforma...”, op. cit., pág. 10. 
sucede en España. Sí existen diferencias en otros aspectos, como las penas, las circunstancias calificadoras o los supuestos a los que se aplica.

Por una parte, en nuestra legislación siempre se han distinguido dos tipos penales y, como hemos observado, desde el Código de 1870, se ha referido de forma expresa al término "asesinato", como también se contemplaba el "parricidio" y el "infanticidio" con esa denominación, y todos ellos presentaban la misma acción típica de matar. Mientras que, por otra parte, hay Estados que solo contemplan el homicidio, que engloba todo acto que implique matar a una persona, y después tienen en cuenta circunstancias calificadoras que agravan la pena pero no establecen el asesinato como un delito autónomo.

Hasta el actual Código Penal de 1995, en España el asesinato se consideraba mayoritariamente un delito autónomo, debido a que las circunstancias que lo califican se entienden como elementos que caracterizan un delito distinto del homicidio. Un amplio sector doctrinal aprecia que el asesinato se ha ido vaciando de contenido y que es un homicidio agravado, motivo por el que el Código Penal lo incluye dentro del título "Del homicidio y sus formas" y no como delito independiente ${ }^{48}$. En la mayoría de los ordenamientos se mantiene el término "asesinato", para calificar los casos más graves de homicidio doloso, tanto si la figura básica es el homicidio y, por lo tanto, el asesinato una cualificación, como si el tipo básico es el asesinato, lo que sucede en la legislación de Austria ${ }^{49}$.

\footnotetext{
48 Silva Sánchez, en Silva Sánchez, J. M. (dir.) (2006). Lecciones de derecho penal. Parte especial. Barcelona: Atelier, pág. 33.

49 Sanz Morán, Á. J. (1995). "Presupuestos para la reforma de los delitos contra la vida", en Anuario de derecho penal y ciencias penales, Tomo 48, Fasc/Mes 3, págs. 804-805.
} 
En el derecho comparado europeo, algunos de los países que establecen un único tipo penal son Italia o Portugal, mientras que otras legislaciones se asemejan más a España, como ocurre en Alemania, Francia o Suiza.

2.2.1. Homicidio como único tipo penal.

2.2.1.1. Italia.

Con una estructura como la de España, el Codice penale ${ }^{50}$ dedica el Libro II a la parte especial, que tipifica los delitos (Dei delitti in particolare). Los atentados contra la vida se contemplan en su Título XII Dei delitti contro la persona, Capítulo I Dei delitti contro la vita e l'incolumità individuale (delitos contra la vida y la seguridad). En primer lugar aparece el homicidio (omicidio), la figura es como la española y con los mismos requisitos de acción u omisión por parte del sujeto pasivo y que, con una relación de causalidad, produzca la muerte de otra persona, de manera dolosa o imprudente ${ }^{51}$.

El art. $575^{52}$, sanciona el homicidio con una pena mayor que la de nuestro ordenamiento, con prisión no inferior a veintiún años. Las circunstancias que lo agravan se regulan en los arts. 576 y 577 y se corresponde con lo que nosotros consideramos como asesinato, castigado hasta 1944 con la pena capital. Tras ser abolida ese año, se sustituyó por la

\footnotetext{
${ }^{50}$ Real Decreto de 19 de octubre de 1930, con varias reformas posteriores, la última de ellas en marzo de 2017, [en línea] [Disponible en http://www.ipsoa.it/codici/cp/12/t12]. ${ }^{51}$ Antolisei, F. (2018). Manuale di Diritto Penale. Milán: Giuffrè Editore.

${ }^{52}$ Chiunque cagiona la morte di un uomo è punito con la reclusione non inferiore ad anni ventuno. (Cualquiera que cause la muerte de un hombre será castigado con pena de prisión no inferior a veintiún años).
} 
reclusión perpetua (ergastolo), para los supuestos en los que concurran dichas circunstancias. En este modelo se mezcla la pena de prisión perpetua con la limitación de beneficios penitenciarios para determinados delitos, como los terroristas y la delincuencia organizada ${ }^{53}$. Son las dos modalidades que existen: el ergastolo normal, con el que se pueden conceder permisos especiales o libertad condicional, y el ergastolo ostativo, que niega al condenado dichos beneficios ${ }^{54}$.

Se puede atenuar esta pena, si concurre una circunstancia atenuante, con reclusión de veinte a veinticuatro años y, si concurren varias, puede reducirse a diez ${ }^{55}$. En caso de ergastolo, no se puede solicitar la libertad condicional hasta pasados veintiséis años. Si se concede la libertad y pasan cinco años sin revocarla, se considera extinguida la pena ${ }^{56}$.

Delpino $^{57}$ las ordena de la siguiente manera:

- Agravantes relativas al elemento subjetivo del delito:

- Premeditación, que requiere un elemento cronológico, que transcurra un lapso de tiempo entre el propósito criminal y la actuación; y otro ideológico, es decir, la persistencia de la resolución criminal firme e irrevocable.

- Por motivos abyectos o fútiles. Se consideran abyectos los infames y despreciables que revelan "la perversidad del autor y suscitan repugnancia según el sentimiento común”,58. Para

53 Cervelló Donderis, V. (2015). Prisión perpetua y de larga duración. Régimen jurídico de la prisión permanente revisable. Valencia: Tirant lo Blanch, pág. 59.

${ }_{54}$ Casals Fernández, Á. (2019). La prisión permanente revisable. Madrid: Agencia Estatal Boletín Oficial del Estado ( $1^{\mathrm{a}}$ ed.), pág. 84.

55 Ibid., pág. 82.

${ }^{56}$ Ibid., pág. 84.

57 Delpino, L. (2011). Diritto Penale parte speciale. Nápoles: Edizioni Giuridiche Simone (18 ${ }^{\mathrm{a}}$ ed.).

${ }^{58}$ Mantovani, citado por Alonso Álamo (2015). El ensañamiento, op. cit., pág. 25. 
Torío, el móvil abyecto es una característica del ánimo o de la actitud personal ${ }^{59}$.

- Relativas a la modalidad de la acción o el medio usado:

- Con torturas o crueldad. La sevicia o crueldad se encuentra más próxima al ensañamiento español que los motivos abyectos o fútiles, debido a que la interpretación de estas circunstancias por parte de la doctrina italiana se aproxima al ensañamiento de nuestro Código Penal. Para que haya una actuación cruel se necesita un elemento objetivo (infligir males innecesarios), uno subjetivo (la voluntad de causarlos) y otro valorativo (el comportamiento debe ser expresión de la perversidad del autor). La jurisprudencia italiana mantiene que la crueldad hacia la persona se concreta "en una carencia de sentimientos de piedad y de humanidad y en la especial insensibilidad del autor" ${ }^{\prime 60}$.

- Si se emplean sustancias venenosas o medios insidiosos.

- Dependientes de la conexión con otros delitos.

- Con un nexo teleológico y consecuencial.

- Cuando se ha causado la muerte cometiendo otros delitos como violación u otros relativos a la libertad sexual.

- Según el sujeto activo o la víctima:

- Si es el autor un fugitivo que está huyendo.

- Cuando hay asociación para delinquir.

${ }^{59}$ Torío López, Á., op. cit., pág. 109.

${ }^{60}$ Alonso Álamo (2015). El ensañamiento, op. cit., págs. 26 y 27. 
- Si la víctima es policía.

- Debidas a la existencia de relación de parentesco entre el agresor y la víctima.

- Contra ascendientes o descendientes.

- Contra cónyuges, hermanos, padres o hijos adoptivos, o afines en línea recta.

Asimismo regula los tipos atenuados que también aparecen en nuestro ordenamiento, como la incitación y la ayuda al suicidio ${ }^{61}$ y mantiene, a diferencia de la legislación española vigente, la figura del infanticidio $^{62}$ en el art. $578^{63}$.

\subsubsection{Portugal.}

Igualmente figura en el Libro II $^{64}$, Título I Dos crimes contra a vida, Capítulo I Dos crimes contra a vida. Como en Italia, el tipo simple es el homicidio (homicídio), que se sanciona en el art. $131^{65}$ con pena de prisión de ocho a dieciséis años. El tipo agravado (homicídio qualificado), entendido como equivalente al asesinato, se regula en el art. el 132, castigado con prisión de doce a veinticinco años.

Las circunstancias calificadoras incluyen cuando los sujetos pasivos son los ascendientes, descendientes, cónyuges o personas indefensas; si se

\footnotetext{
${ }^{61}$ Art. 580, castigado con pena de prisión de cinco a doce años.

${ }^{62}$ La Ley de 5 de agosto de 1981 derogó la causa de honor (causa d'onore).

${ }^{63}$ Sancionado con prisión de cuatro a doce años, para la madre.

${ }^{64}$ Código Penal aprobado por el Decreto-Lei 48/95. La última reforma fue aprobada en marzo de 2017, [en línea] [Disponible en https://dre.pt/web/guest/legislacaoconsolidada/-/lc/34437675/view?w=2017-03-03].

${ }^{65}$ Quem matar outra pessoa é punido com pena de prisão de 8 a 16 anos.
} 
produce con ensañamiento $^{66}$; con uso de veneno; para encubrir o preparar otro delito; si el sujeto activo es un funcionario que realiza la acción con abuso de autoridad; por odio racial, religioso, político, etc.

Otros tipos reconocidos en la legislación portuguesa son: el homicidio privilegiado ${ }^{67}$, a petición de la víctima ${ }^{68}$, la incitación y la ayuda al suicidio ${ }^{69}$ y el homicidio por negligencia ${ }^{70}$, además de, como en el caso de Italia, el infanticidio, con pena de prisión de uno a cinco años ${ }^{71}$.

2.2.2. Homicidio y asesinato como dos tipos penales diferenciados.

A continuación pasamos al análisis de las legislaciones que contemplan los delitos contra la vida como en el ordenamiento español, que distingue el homicidio del asesinato, a diferencia de los países que lo contemplan como una sola figura agravada en algunos casos.

\subsubsection{Alemania.}

El Código Penal Alemán (Strafgesetzbuch o $S t G B)^{72}$ presenta una estructura dispar a la española, ya que establece el asesinato (Mord) en primer lugar, como tipo básico, dentro de la "Parte especial", en la Sección XVI "Delitos contra la vida", y lo sanciona con prisión perpetua

${ }^{66}$ No lo indica con ese nombre pero se refiere a la circunstancia en la que se emplea tortura o actos de crueldad para aumentar el sufrimiento de la víctima: empregar tortura ou auto de crueldade para aumentar o sofrimento da vítima.

${ }^{67}$ Art. 133: matar por compasión se castiga con prisión de uno a cinco años.

${ }^{68}$ Art. 134: con pena de prisión hasta tres años.

${ }^{69}$ Art. 135: en general, castigado con prisión hasta tres años.

${ }^{70}$ Art. 137: con pena de prisión hasta tres años o multa.

${ }^{71}$ Art. 136.

${ }^{72}$ Versión publicada por el Bundesministerium der Justiz und für Verbraucherschutz (Ministerio de Justicia y para la protección del consumidor), el 13 de noviembre de 1998, cuyas últimas modificaciones han sido realizadas en abril de 2017, [en línea] [Disponible en http://www.gesetze-im-internet.de/stgb/]. 
(lebenslanger Freiheitsstrafe) en el parágrafo $211^{73}$. La concesión de libertad del penado en estos casos se regula como suspensión de la pena, añadido en 1997 tras una sentencia del Constitucional alemán que determinaba que no se puede imponer la pena privativa de libertad de por vida sin que exista la posibilidad de suspenderla tras el tiempo establecido. Esta suspensión exige que se justifique según los intereses de la seguridad del público y que el condenado acepte. El plazo mínimo es de quince años en todos los casos, ampliable en función del grado de culpabilidad o la peligrosidad del sujeto ${ }^{74}$.

Según el $S t G B$, es asesino quien mata para satisfacer un deseo sexual, por codicia, con alevosía, de manera cruel o para encubrir otro delito. "En 1941 desapareció la circunstancia de "deliberación" (Überlegung) del viejo Código penal de 1871, circunstancia que definía el asesinato y que no coincidía con la circunstancia de premeditación de la tradición jurídica española o italiana"75.

Las modalidades $\operatorname{son}^{76}$ :

- Actuar por una determinada razón especialmente reprochable, como puede por ser motivaciones sexuales o económicas. Esta es una de las diferencias con la regulación española, ya que esta no descansa en la especial motivación del autor, ni exige un móvil concreto que impulse la acción, ni tampoco una especial actitud interna referida al placer de $\operatorname{matar}^{77}$.

\footnotetext{
${ }^{73}$ Der Mörder wird mit lebenslanger Freiheitsstrafe bestraft. (El asesino será castigado con privación de libertad toda su vida).

${ }^{74}$ Casals Fernández, op. cit., págs. 66 y ss.

75 Alonso Álamo, M. (2015). "La reforma...", op. cit., pág. 11.

${ }^{76}$ Küpper, G. (1996). Strafrecht Besonderer Teil 1. Delikte gegen Rechtsgüter der Person und Gemeinschaft. Berlín: Springer Lehrbuch, págs. 8-15.

${ }^{77}$ Alonso Álamo (2015). El ensañamiento, op. cit., pág. 37. 
- Por el modo de realizarlo: por ejemplo con traición o crueldad, lo que equivale a nuestra alevosía y el ensañamiento.

- Para facilitar u ocultar otro delito, regulado de manera semejante a esta característica introducida en la reforma española de 2015.

Si en el acto de matar no concurren dichas circunstancias, el autor es responsable por homicidio (Totschlag) ${ }^{78}$, delito castigado con pena de prisión no inferior a cinco años que, en supuestos de gravedad, puede llegar a cadena perpetua. Asimismo regula la inducción o auxilio al suicidio, que conlleva prisión hasta tres años o multa ${ }^{79}$ y también la eutanasia, denominada Tötung auf Verlangen, cuya traducción aproximada equivale a “muerte por petición”, a la que corresponde una pena de prisión de seis meses a cinco años ${ }^{80}$, es decir, que la pena máxima es más alta que la de la cooperación al suicidio en general.

\subsubsection{Austria.}

El Código Penal de Austria (1975) tiene una regulación muy parecida a la alemana. El homicidio ${ }^{81}$ es sancionado con prisión entre cinco y diez años, caracterizado por la emoción especial que tiene el perpetrador en el momento de ejecutar el acto. Dicha emoción debe ser violenta, que incluso venza fuertes inhibiciones morales ${ }^{82}$.

\footnotetext{
78 § 212: Wer einen Menschen tötet, ohne Mörder zu sein, wird als Totschläger mit Freiheitsstrafe nicht unter fünf Jahren bestraft. (Quien mate a un hombre sin ser asesino, será castigado como homicida con privación de libertad no inferior a cinco años).

$79 \S 217$.

$80 § 216$.

81 § 76: Totschlag: matar a otra persona llevado por una emoción.

${ }^{82}$ Haberl, H. (1981). Das österreichische Strafgesetzbuch. Graz, pág. 98.
} 
El asesinato se castiga con pena de entre diez y veinte años o reclusión perpetua ${ }^{83}$. También contempla las modalidades de eutanasia, auxilio al suicidio, infanticidio ${ }^{84}$ y homicidio por imprudencia, con penas menores.

Además hay numerosos hechos que, si producen la muerte de una persona, conllevan asimismo la pena perpetua, por ejemplo, determinados secuestros; cuando se produce un robo en el seno de una organización criminal y, como causa de la violencia ejercida, acaban en asesinato; producir y distribuir armas de destrucción masiva; atentar por la fuerza en una aeronave, contra su seguridad, en este último caso cuando la muerte sea la de varias personas.

\subsubsection{Bélgica.}

El código belga, de 1867 (Code Pénal), sigue una estructura diferente a la de otros países y más semejante a la regulación histórica española. En su Libro II comienza por delitos contra la Corona, la seguridad interior y exterior del Estado, la fe pública, etc., mientras que el homicidio aparece en el Título VIII, dentro de los delitos contra las personas, en su Capítulo I, que tipifica el homicidio, las lesiones corporales voluntarias y los tratamientos inhumanos y degradantes.

El art. 392 regula el homicide, que es el término genérico que utiliza para causar la muerte de una persona. Después hace referencia a la meurtre $^{85}$, que implica intención de provocar la muerte, lo que sería un

\footnotetext{
83 § 75: Mord: matar a otra persona.

${ }^{84} \S 79$. No utiliza un término específico pero se refiere a la madre que mate al hijo al nacer o durante el parto. La pena es de prisión entre seis meses y cinco años.

${ }^{85}$ L'homicide commis avec intention de donner la mort est qualifié meurtre. Il sera puni (de la réclusion de vingt ans à trente ans). (La muerte cometida con intención de 
equivalente al homicidio, y se pena con entre veinte y treinta años de prisión y el assassinat ${ }^{86}$, que es el homicidio cometido con premeditación ${ }^{87}$ y se castiga con reclusión perpetua. También esa pena a perpetuidad conlleva el asesinato por envenenamiento ${ }^{88}$ y el delito de parricidio $^{89}$, entendido por tal matar a los padres u otros ascendientes.

La legislación belga hace referencia expresa al infanticidio ${ }^{90}$, consistente en matar a un niño en el momento de su nacimiento o inmediatamente después y se considera homicidio o asesinato, dependiendo de las circunstancias.

\subsubsection{Francia.}

Algunos autores consideran que en Francia el asesinato no constituye un delito autónomo sino un homicidio agravado ${ }^{91}$. Sin embargo, al especificar el término el propio Código Penal francés y establecer las agravantes que se aplican a ese tipo delictivo y como sí lo entienden otros autores en legislaciones similares, como Goedseels ${ }^{92}$, quien manifiesta que no es una circunstancia agravante sino un elemento constitutivo de asesinato, hemos decidido incluirlo en este apartado, junto con los otros países que regulan ambas figuras.

causarla se califica como homicidio. Será castigado con la prisión de veinte a treinta años). Art. $393 \mathrm{CP}$ belga.

${ }^{86}$ Le meurtre commis avec préméditation est qualifié assassinat. Il sera puni (de la réclusion à perpétuité). (El homicidio cometido con premeditación se califica como asesinato. Será castigado con la reclusión a perpetuidad). Art. $394 \mathrm{CP}$ belga.

${ }^{87}$ La premeditación es el tema de una de las preguntas principales dirigidas al jurado. Goedseels, Jos. M. C. X. (1948), Commentaire du Code Pénal Belge. Tomo $2^{\circ}$. Bruselas: Établissements Émile Bruylant (2ª ed.), pág. 125.

${ }^{88}$ Art. 397 CP belga.

${ }^{89}$ Art. 395 CP belga.

${ }^{90}$ Art. 396 CP belga.

${ }_{91}^{91}$ André C. (2017). Droit pénal spécial. París: Dalloz (4ª ed.), pág. 74.

${ }^{92}$ Goedseels (op. cit.). 
El Code pénal ${ }^{93}$ contempla estos delitos en el Libro II Des crimes contre l'humanité et contre l'espèce humaine (delitos contra la humanidad y la especie humana) -que comienza con la tipificación del genocidio- Título II Des atteintes à la vie de la personne, Capítulo I. En la Sección I se regulan los ataques voluntarios contra la vida: el homicidio (meurtre), en el (art. 221-1 $)^{94}$, penado con treinta años de prisión e incluso, en determinados supuestos, con prisión perpetua, cuando el homicidio se comete para preparar o facilitar otro delito o para procurar la impunidad de su autor.

El asesinato (assassinat) también está castigado con prisión perpetua, como dispone el art. 221-3 ${ }^{95}$. En estos casos el periodo de prueba es de dieciocho años y, si es reincidente, veintidós ${ }^{96}$.

El Código francés establece que, si concurren las siguientes agravantes, el autor es responsable de asesinato:

- Matar con premeditación o emboscada.

- En función de la víctima, que sea menor de quince años, ascendientes, personas especialmente vulnerables por enfermedad o edad, jueces, abogados, policías, etc.

- En concurso con otros delitos.

Además, regula de manera independiente el delito de envenenamiento (empoisonnement, art. 221-5) ${ }^{97}$, castigado con treinta años

\footnotetext{
93 Aprobado en 1992. Su última reforma es de septiembre de 2019, [en línea] [Disponible en

https://www.legifrance.gouv.fr/affichCode.do?cidTexte=LEGITEXT000006070719\&da teTexte $=20170516]$.

${ }^{94}$ Le fait de donner volontairement la mort à autrui constitue un meurtre. Il est puni de trente ans de réclusion criminelle. (Causar voluntariamente la muerte a otro constituye un homicidio. Se castiga con treinta años de prisión).

${ }^{95}$ Le meurtre commis avec préméditation ou guet-apens constitue un assassinat. Il est puni de la réclusion criminelle à perpétuité. (El homicidio cometido con premeditación o emboscada constituye un asesinato. Es castigado con prisión perpetua).

${ }^{96}$ Casals Fernández, op. cit., pág. 95.
} 
de prisión. El envenenamiento "arraigado en la tradición francesa, se cumple con el mero uso del medio criminal" $"$.

\subsubsection{Países Bajos.}

El art. $287^{99}$ de su Código Penal (Wetboek van Strafrecht) tipifica el homicidio (doodslag), como la conducta de quien, sin premeditación, priva deliberadamente de la vida a otra persona, delito castigado con hasta quince años de prisión. En el art. 289, aparece el asesinato (moord), que consiste en la privación de la vida en los casos en los que se comete con finalidad terrorista o cuando se trata de actos precedidos por un delito o cometidos para preparar o facilitar otro. La pena es de prisión perpetua o temporal hasta treinta años. No contempla su legislación la posibilidad de libertad, salvo por indulto y no se ha establecido un sistema de revisión ${ }^{100}$.

Esta pena perpetua se aplica en múltiples hechos deliberados si por causa de ellos se produce la muerte: disparar; causar una explosión o una inundación; exponer deliberadamente a personas, animales, plantas o bienes a radiación o infectar con sustancias radiactivas; destruir deliberadamente dispositivos para la seguridad del tráfico o la navegación...

También castiga el infanticidio, aunque no utiliza un término específico para este delito, con hasta seis años de prisión, para la madre que mata a su hijo en el nacimiento o poco después ${ }^{101}$.

\footnotetext{
${ }^{97}$ Le fait d'attenter à la vie d'autrui par l'emploi ou l'administration de substances de nature à entraîner la mort constitue un empoisonnement. L'empoisonnement est puni de trente ans de réclusion crimminelle.

${ }_{98}$ Alonso Álamo, M. (2015). "La reforma...", op. cit., pág. 14.

${ }^{99}$ Dentro del Libro Segundo, Título XIX “Delitos contra la vida”. [en línea] [Disponible en http://wetten.overheid.nl/BWBR0001854/2018-01-01\#BoekTweede].

${ }^{100}$ Casals Fernández, op. cit., pág. 116.

${ }^{101}$ Art. 290 del CP holandés.
} 


\subsubsection{Reino Unido.}

Partiendo de la particularidad de que en el Reino Unido no existe una única legislación, son varias las normas que tipifican estos delitos. Además, al basarse el sistema anglosajón especialmente en la jurisprudencia y el derecho no escrito (common law) ${ }^{102}$, tampoco tienen un código penal que compile toda la materia delictual, ya que su sistema se rige por las decisiones judiciales y el Statute Law ${ }^{103}$, es decir, las leyes (Acts) del Parlamento. Por ese motivo analizaremos las leyes aplicables a Inglaterra y Gales, que son las más conocidas dentro del territorio británico.

Ambas figuras aparecen en la Corporate Manslaughter and Corporate Homicide Act de $2007^{104}$, reformada brevemente en 2011. Los dos términos hacen referencia al homicidio culposo. Manslaughter es el vocablo empleado para el homicidio en Inglaterra, Gales e Irlanda del Norte, mientras que homicide es usado en Escocia ${ }^{105}$.

Se castiga con cadena perpetua (imprisonment for life), pena aplicable a los delitos que conllevaban la pena de muerte y que sustituyó a esta cuando fue abolida en 1965 y que, en estos casos de asesinato, puede dictarse orden de cumplimiento durante toda la vida, además de no haberse fijado un plazo legal para la posibilidad de libertad ni condiciones para

\footnotetext{
102 Cardenal Montraveta, S. (2007). "Los delitos relacionados con la seguridad del tráfico en el derecho comparado", en InDret, revista para el análisis del derecho, $\mathrm{n}^{\circ} 3$.

103 Sánchez Osés, J. (1956), "La codificación del Derecho penal en Inglaterra", en Anuario de derecho penal y ciencias penales, Tomo 9, Fasc/Mes 2, pág. 271. Ministerio de Justicia.

104 Página de legislación del Reino Unido [en línea] [Disponible en http://www.legislation.gov.uk/].

${ }^{105}$ En EEUU incluso existe una modalidad agravada de asesinato, el asesinato en primer grado (first degree), que es deliberado o premeditado. Klotter, J. C. (2001). Criminal Law. Cincinnati: Anderson (6 ${ }^{\mathrm{a}}$ ed.), pág. 65.
} 
acogerse a ese derecho ${ }^{106}$, cuando el condenado tenga, al menos, veintiún años ${ }^{107}$. Escocia no la contempla en su legislación.

El homicidio es todo acto ilegal (que no presente causas de justificación) por el que una persona mata a otra. Dentro de esta definición general, lo clasifica en tres grupos:

- La muerte dolosa considerada asesinato (murder $)^{108,109}$ que incluye los siguientes supuestos ${ }^{110}$ :

- Asesinatos cometidos en el transcurso de un robo.

- Por disparos o explosiones.

- Para evitar un arresto o ayudar a escapar de custodia legal.

- Asesinar a un policía o a un funcionario de prisiones que se encuentre ejerciendo el cumplimiento de su deber.

- El homicidio voluntario (voluntary manslaughter). El homicidio se da cuando no existe la malicia premeditada que requiere el asesinato pero sí se produce la muerte de manera intencional, aunque con circunstancias atenuantes que disminuyen su culpabilidad (mitigating

\footnotetext{
${ }^{106}$ Casals Fernández, op. cit., pág. 104.

${ }^{107}$ Roig Torres, M. (2016). La cadena perpetua en el derecho alemán y británico, la prisión permanente revisable. Madrid: Iustel, pág. 74 .

108 Tradicionalmente la nota definitoria del asesinato ha sido la llamada "malicia premeditada" (malice aforethought), que es la intención criminal exigida para llevar a cabo la muerte. Allen, M. J. (2001) Textbook on Criminal Law. Nueva York: Oxford University Press (6ª ed.), pág. 297.

${ }^{109}$ Existe una doctrina vigente en algunos países del mundo anglosajón, por la que si, durante el transcurso de la ejecución de un delito (por ejemplo un atraco), perpetrado por varias personas, una de ellas comete un asesinato, todas son acusadas por ese asesinato, es la llamada felony murder rule.

${ }^{110}$ Parte II.5. de la Ley de homicidio (Homicide Act), de 1957.
} 
factors), como por ejemplo que medie provocación ${ }^{111}$ o el calor del momento $^{112}$.

- Homicidio involuntario (involuntary manslaughter), la muerte accidental en la que el autor no tiene intención criminal de matar ni dañar a la otra persona.

\subsubsection{Suiza.}

El código suizo ${ }^{113}$ titula su Libro II "Disposiciones especiales". Regula los dos tipos penales en el Título I "Delitos contra la vida y la integridad de la persona”. El homicidio (Totschlag) ${ }^{114}$ aparece en el art. 111 y sanciona con pena de prisión no inferior a cinco años ${ }^{115}$ a los que matan a una persona. En el siguiente artículo (112) ${ }^{116}$ aparece e $<1$ asesinato (Mord), que castiga la acción con pena de prisión permanente o, en todo caso, no inferior a diez años.

${ }^{111}$ En ocasiones puede llegar a constituir una eximente. "La provocación ha de ser considerable, la muerte tiene que producirse bajo el impacto inmediato de la provocación". Giles, F. T. (1957). El Derecho Penal inglés y su procedimiento. Barcelona: Bosch, pág. 201.

${ }_{112}^{112}$ Allen, op. cit., pág. 299.

113 Código Penal de 1937, versión de 2011, [en línea] [Disponible en http://www.wipo.int/wipolex/es/details.jsp?id=11027].

${ }^{114}$ Aunque existen cuatro idiomas oficiales en Suiza, se ha optado por la terminología del alemán, ya que es el mayoritario.

115 Wer vorsätzlich einen Menschen tötet, ohne dass eine der besondern Voraussetzungen der nachfolgenden Artikel zutrifft, wird mit Freiheitsstrafe nicht unter fünf Jahren bestraft. (Quien mata deliberadamente a una persona, sin los requisitos del artículo siguiente -el del asesinato-, será castigado con prisión no inferior a cinco años).

116 Handelt der Täter besonders skrupellos, sind namentlich sein Beweggrund, der Zweck der Tat oder die Art der Ausführung besonders verwerflich, so ist die Strafe lebenslängliche Freiheitsstrafe oder Freiheitsstrafe nicht unter zehn Jahren. (El que realice el hecho de forma especialmente despiadada o con un método de ejecución perverso, será castigado con prisión permanente o pena de prisión no inferior a diez años). 
En la siguiente tabla figuran las diversas penas que establecen los países mencionados, con la separación entre los estados que tipifican solo el homicidio, con sus agravantes, y los que contemplan dos tipos penales diferenciados, homicidio y asesinato:

\begin{tabular}{|c|c|c|c|}
\hline & Homicidio & Asesinato & $\begin{array}{c}\text { Homicidio agravado / } \\
\text { calificado }\end{array}$ \\
\hline Alemania & No menos de 5 años & Reclusión perpetua & \\
\hline Austria & 5 a 10 años & $\begin{array}{l}10 \text { a } 20 \text { años / } \\
\text { reclusión perpetua }\end{array}$ & \\
\hline Bélgica & 20 a 30 años & Reclusión perpetua & \\
\hline España & 10 a 15 años & $\begin{array}{c}15 \text { a } 25 \text { años / } \\
\text { prisión permanente revisable }\end{array}$ & \\
\hline Francia & $\begin{array}{l}30 \text { años / prisión } \\
\text { perpetua }\end{array}$ & Prisión perpetua & \\
\hline Italia & No inferior 21 años & & Prisión perpetua \\
\hline $\begin{array}{l}\text { Países } \\
\text { Bajos }\end{array}$ & Hasta 15 años & $\begin{array}{l}\text { Hasta } 30 \text { años / } \\
\text { prisión perpetua }\end{array}$ & \\
\hline Portugal & 8 a 16 años & & 12 a 25 años \\
\hline $\begin{array}{l}\text { Reino } \\
\text { Unido } \\
\end{array}$ & Prisión permanente & Prisión permanente & \\
\hline Suiza & No menos de 5 años & $\begin{array}{l}\text { Prisión permanente / no menos } \\
\text { de } 10 \text { años }\end{array}$ & \\
\hline
\end{tabular}

Tabla 02. Los tipos penales en derecho comparado y sus correspondientes penas.

Fuente: elaboración propia. 


\section{ESTUDIO DE LOS DELITOS CONTRA LA VIDA EN EL ORDENAMIENTO JURÍDICO ESPAÑOL VIGENTE.}

Ya que, como se ha explicado en la introducción, los delitos objeto del estudio del análisis de los veredictos son el homicidio y el asesinato, a continuación, pasamos a exponer su regulación vigente dentro de nuestro sistema penal.

La vida es el bien jurídico más importante que poseemos los seres humanos, por eso su protección penal se garantiza, con distintas penas y modalidades, en todos los ordenamientos jurídicos del mundo.

Por ese motivo, en el ordenamiento jurídico español la vida tiene una tutela constitucional y penal máxima. La Constitución de 1978 (CE) garantiza este derecho fundamental en el art. 15: Todos tienen derecho a la vida y a la integridad física y moral, sin que, en ningún caso, puedan ser sometidos a tortura ni a penas o tratos inhumanos o degradantes. Queda abolida la pena de muerte, salvo lo que puedan disponer las leyes penales militares para tiempos de guerra.

Por su parte, la Ley Orgánica 10/1995, de 23 de noviembre, del Código Penal (CP) regula los delitos objeto de este trabajo -homicidio y asesinato- antes que el resto de tipos penales, a diferencia de lo que hemos visto en las legislaciones anteriores, puesto que, aunque históricamente siempre se han castigado estas figuras, la estructura ha cambiado y esta es la primera ocasión en la que los delitos contra la vida aparecen en primer lugar. Tradicionalmente eran más importantes los delitos contra el Estado (la Constitución, la seguridad interior y exterior, etc.) pero, dada la evolución de los derechos humanos y la adaptación social al contexto histórico, empieza a considerarse que los delitos contra las personas prevalecen sobre todos los demás y por ese motivo ahora figuran en primer lugar. Avelina Alonso expone que en los anteriores Códigos Penales 
"Estaba clara la intención del legislador: una absoluta primacía a la protección del Estado, a la forma propia de gobierno, cualquiera que esta fuera (...). Sin embargo, el Código Penal vigente, siguiendo el orden de valores proclamado por la Constitución, opta por comenzar la parte especial, protegiendo el bien jurídico por excelencia: la vida" ${ }^{\$ 17}$.

De esta forma, en el Libro II, que tiene por rúbrica "Delitos y sus penas", se sancionan los ataques contra la vida humana independiente en el Título I, "Del homicidio y sus formas". Muñoz Conde explica que en el anterior Código Penal el título era "Delitos contra las personas", donde se recogían los delitos contra la vida y la integridad corporal. Hoy se considera "que la persona, además de ser titular de su vida e integridad física, es titular de otros valores que son también objeto de protección jurídico-penal, como, por ejemplo, el honor, la libertad, la integridad moral y el patrimonio. Por eso a la expresión "Delitos contra las personas" debe dársele un sentido más amplio, capaz de abarcar todos los delitos que atacan valores pertenecientes al ámbito de la persona y que son objeto de protección penal”"118.

A continuación, para la exposición de los tipos delictivos contra la vida independiente, seguiremos el orden establecido en el Código Penal, en primer lugar el tipo básico del homicidio simple (art. 138.1), la novedad del homicidio agravado (art. 138.2), el asesinato (art. 139) y el asesinato hipercualificado o hiperagravado (art. 140).

\footnotetext{
117 Alonso de Escamilla, A. (2017). "Delitos contra la vida humana independiente: homicidio, asesinato y suicidio", en Lamarca Pérez, C. (coord.) (2017). Delitos. La parte especial del Derecho penal. Madrid: Dykinson (2a ed.), pág. 3.

118 Muñoz Conde, F. (2015). Derecho Penal. Parte Especial. Valencia: Tirant (20a ed.), pág. 25.
} 


\subsection{El homicidio.}

En primer lugar, el delito de homicidio aparece en el art. 138 que dispone lo siguiente:

1. El que matare a otro será castigado, como reo de homicidio, con la pena de prisión de diez a quince años.

2. Los hechos serán castigados con la pena superior en grado en los siguientes casos:

a) cuando concurra en su comisión alguna de las circunstancias del apartado 1 del artículo $140^{119}$, o

b) cuando los hechos sean además constitutivos de un delito de atentado del artículo $550^{120}$.

Tanto la jurisprudencia como la doctrina explican los elementos característicos del homicidio, que requiere la concurrencia de los siguientes factores en la integración del tipo ${ }^{121}$ :

- Causación de la muerte de otra persona, es decir, la destrucción de la vida humana mediante la acción del sujeto activo.

- Una relación causal entre esa conducta del sujeto autor del ilícito penal y el resultado de la muerte.

- La presencia de un dolo, del tipo que sea, con la aceptación del resultado previsto.

\footnotetext{
${ }_{119}$ Art. que tipifica el asesinato.

120 Son reos de atentado los que agredieren o, con intimidación grave o violencia, opusieren resistencia grave a la autoridad, a sus agentes o funcionarios públicos, o los acometieren, cuando se hallen en el ejercicio de las funciones de sus cargos o con ocasión de ellas.

${ }^{121}$ González Cussac en González Cussac, J. L. (coord.) (2016). Derecho Penal parte especial. Valencia: Tirant ( $5^{\text {a }}$ ed.), págs. 43-46.
} 
Por lo tanto, siguiendo estos elementos, la acción típica es quitar la vida a un ser humano, independientemente del medio que se utilice. Se protege el bien jurídico de la vida humana como valor ideal ${ }^{122}$. Es un delito de resultado en el que también se contempla la tentativa, que requiere dolo y un principio de ejecución ${ }^{123}$; y la comisión por omisión, que exige que el sujeto activo tenga una posición de garante respecto a la muerte del sujeto pasivo, que exista una relación causal entre la omisión y la producción de un resultado y que la omisión suponga la infracción de un deber jurídico de actuar, bien por obligación legal o contractual ${ }^{124}$, o porque el omitente genere un riesgo por una acción u omisión precedente, como exige el art. 11 del Código Penal ${ }^{125}$.

El objeto material ${ }^{126}$ sobre el que recae la acción del delito de homicidio es una persona viva físicamente considerada ${ }^{127}$, es decir, no cabe sobre un cadáver ni tampoco sobre los animales. Cualquier persona puede ser sujeto activo de este delito (quien lo comete) y también sujeto pasivo (la víctima). Existen algunas excepciones que implican ciertas particularidades, como por ejemplo:

\footnotetext{
${ }^{122}$ Muñoz Conde (2015), op cit., pág. 34.

${ }^{123}$ Cerezo Mir, J. (2005). Curso de derecho penal español. Parte general. Madrid: Tecnos (6 ${ }^{a}$ edición), págs. 185-195.

${ }^{124}$ FD 15 de la STS 1828/2018, de 24 de mayo.

${ }^{125}$ Los delitos que consistan en la producción de un resultado sólo se entenderán cometidos por omisión cuando la no evitación del mismo, al infringir un especial deber jurídico del autor, equivalga, según el sentido del texto de la ley, a su causación. A tal efecto se equiparará la omisión a la acción:

a) Cuando exista una específica obligación legal o contractual de actuar.

b) Cuando el omitente haya creado una ocasión de riesgo para el bien jurídicamente protegido mediante una acción u omisión precedente.

${ }^{126}$ El ser humano puede ser objeto material de los delitos contra la vida desde que empieza (cuando se transforma en persona) hasta que termina su existencia como tal ser. Stampa Braun, J. M (1950). "El objeto material de los delitos contra la vida", en Anuario de derecho penal y ciencias penales, tomo 3, fasc/mes 3, págs. 519-555.

${ }^{127}$ Muñoz Conde (2015), op.cit., pág. 34.
} 
- Matar al Rey o ciertas personas allegadas ${ }^{128}$, ya que se engloba dentro de los delitos contra la Corona, a su vez incluidos en el Título XXI "Delitos contra la Constitución".

- Los homicidios con finalidad terrorista (art. $573 \mathrm{CP}$, dentro del Título XXII "Delitos contra el orden público", en su Cap. VII "De las organizaciones y grupos terroristas y de los delitos de terrorismo"). Se castiga a quien atente, entre otros bienes jurídicos, contra la vida o la integridad física de alguien con el objetivo de subvertir el orden constitucional, alterar la paz pública, desestabilizar una organización internacional o provocar un estado de terror en la población.

- Cuando la víctima es un Jefe de Estado extranjero o una persona internacionalmente protegida, según el art. $605 \mathrm{CP}$, en el Título XXIV “Delitos contra la Comunidad Internacional", Cap. I "Delitos contra el derecho de gentes".

- En ese mismo título pero en el Cap. II, se regulan los delitos de genocidio y así se castiga el asesinato que se cometa con propósito de destruir total o parcialmente un grupo nacional, étnico, racial, religioso o determinado por la discapacidad de sus integrantes (art. $607 \mathrm{CP})$.

Sobre la segunda característica del homicidio, se exige que haya una relación de causalidad ${ }^{129}$ entre la acción del sujeto activo y el resultado de muerte, de manera que permita imputar objetivamente el resultado a la

${ }^{128}$ Art. 485.1 CP: El que matare al Rey o a la Reina o al Príncipe o a la Princesa de Asturias será castigado con la pena de prisión permanente revisable.

${ }^{129}$ Entre otras, la STS 82/2016, de 19 de enero, establece que "la relación de causalidad es la teoría de la imputación objetiva a través de la cual debe explicarse la relación que ha de existir entre la acción y el resultado típico. Esta construcción parte de la relación que ha de existir entre la acción y el resultado, constatación que se realiza a partir de la teoría de la relevancia, comprobando la existencia de una relación natural entre la acción y el resultado". (FJ 3). 
acción del sujeto, es decir, que el autor ejecute una acción que genere un peligro jurídicamente desaprobado. Esa imputación objetiva requiere tres elementos $^{130}$ :

- que el autor, con una conducta peligrosa, cree un riesgo para el bien jurídico (conditio sine qua non, según la teoría de la equivalencia de las condiciones ${ }^{131}$ ), lo que excluiría, por tanto, las acciones que no son objetivamente peligrosas.

- que ese riesgo sea jurídicamente desaprobado.

- que esa peligrosidad o riesgo penalmente desaprobado sea suficiente como para que se concrete en el resultado final.

"Un resultado causado por el agente sólo se puede imputar al tipo objetivo si la conducta del autor ha creado un peligro para el bien jurídico no cubierto por un riesgo permitido y ese peligro también se ha realizado en el resultado concreto" 132 .

Este proceso es independiente y anterior a la catalogación del comportamiento como doloso o culposo ${ }^{133}$. Esto excluiría los supuestos en los que el resultado se hubiera producido igualmente si se da un comportamiento alternativo conforme a Derecho ${ }^{134}$. Así lo expresa Roxin

\footnotetext{
130 Larrauri, E. (1987-1988). "Introducción a la imputación objetiva", en Estudios penales y criminológicos, $\mathrm{n}^{\mathrm{o}} 12$, págs. 230 , citando a Roxin.

131 "Debe considerarse causa toda condición de un resultado que no puede ser suprimida mentalmente sin que desaparezca el resultado concreto". Sin ella no se habría producido el resultado. Roxin, C. (1997). Derecho penal. Parte general. Tomo I, Fundamentos, la estructura de la teoría del delito. Madrid: Civitas, pág. 347.

${ }^{132}$ Larrauri, E., op. cit., pág. 231.

133 Ibid.

${ }^{134}$ Frisch, W. (2015). La imputación objetiva del resultado: desarrollo, fundamentos y cuestiones abiertas. Barcelona: Atelier, pág. 88.
} 
"las consecuencias de un riesgo permitido no son imputables al causante" ${ }^{, 135}$.

Es necesario, por tanto, que exista una peligrosidad de la acción que conduzca al resultado descrito en el tipo delictivo. Exige una relación entre el acto realizado por el sujeto activo, que produce un riesgo no permitido, y el resultado de su acción, "una determinada relación de riesgo, para la cual es razonable exigir no sólo un mínimo riesgo, sino también la ausencia de riesgo permitido" 136 .

La imputación objetiva presume "la atribución de un sentido jurídico-penal específico a los términos legales que expresan la conducta típica, y no una mera descripción del verdadero sentido de dichos términos" $" 137$.

En cuanto a la presencia del tercero de los elementos requeridos, el elemento subjetivo del dolo, en cualquiera de sus formas, en relación con el homicidio caben las dos formas de realización del tipo: el dolo y el homicidio por imprudencia. "El principio del dolo e imprudencia supone la exigencia de alguna de estas dos formas de conexión subjetiva del autor y su hecho, como presupuesto y fundamento de la responsabilidad penal, de forma que la imposición de una pena requiere, además de la producción de un resultado lesivo para un bien jurídico penalmente protegido, la existencia de una vinculación subjetiva entre el autor y el hecho, que resulte disvaliosa para el Derecho" ${ }^{\prime 38}$.

\footnotetext{
135 Roxin, C. (2007). "Injerencia e imputación objetiva”, en Revista penal, no 19, pág. 153.

${ }^{136}$ Mir Puig, S. (2003). "Significado y alcance de la imputación objetiva en derecho penal”, en Revista Electrónica de Ciencia Penal y Criminología, nº 5, pág. 8.

${ }^{137}$ Ibid., pág. 19.

${ }^{138}$ Sanz-Díez de Ulzurrun Lluch, M. (2007). Dolo e imprudencia en el Código Penal Español. Valencia: Tirant lo Blanch, pág. 34.
} 
El homicidio doloso se castiga con el tipo básico del 138, ya que pena a quien mata a otro actuando con los dos rasgos propios del dolo, el cognoscitivo y el volitivo, es decir, con el conocimiento y la voluntad, por parte del autor, de la realización del tipo objetivo. "Obrará con dolo el que haya tenido conocimiento de dicho peligro concreto y desaprobado jurídicamente, pues habría tenido conocimiento de los elementos del tipo objetivo, que caracterizan precisamente el dolo. La aceptación del resultado existe cuando el agente ha preferido la ejecución de la acción peligrosa a la evitación de sus posibles consecuencias" ${ }^{\text {139. }}$.

Al no ser este el objeto de la tesis, no vamos a entrar a valorar el debate sobre la denominada teoría cognitiva del dolo pero sí haremos un breve apunte para prestar atención acerca de este elemento, al formar parte de los delitos contra la vida independiente que se analizan en este trabajo y ser dolosos la mayoría de los homicidios que se enjuician por el jurado en los casos examinados.

Bustos y Hormazábal definen el dolo de la siguiente manera: "obra dolosamente el que con conocimiento de la situación objetiva quiere llevar a cabo el comportamiento típico y lo lleva a cabo"140. Dicho de otro modo, "quien realiza un tipo, pese a estar intelectual y físicamente en condiciones de evitarlo, realiza un injusto jurídico-penal"141, lo fundamental es establecer el conocimiento que tiene el autor del hecho sobre la relación de causalidad entre su conducta y un resultado típico.

Para Ragués i Vallès "el dolo deberá implicar, por lo menos, la realización de un hecho constitutivo de infracción penal con correcto

\footnotetext{
${ }^{139}$ González Cussac, en González Cussac (coord.), op cit., pág. 47.

${ }^{140}$ Bustos Ramírez, J. J. y Hormazábal Malareé, H. (2004). Nuevo sistema de Derecho Penal. Madrid: Trotta, pág. 83.

${ }^{141}$ Kindhäuser, U. (2006). "Imputación objetiva y subjetiva en el delito doloso", en Anuario de derecho penal y ciencias penales, Tomo 59, Fasc/Mes 1, pág. 64.
} 
conocimiento de las circunstancias que integran el tipo de dicha infracción"142. Actúa dolosamente quien sabe lo que hace (elemento cognitivo) y quiere hacerlo (elemento volitivo), es decir, supone el conocimiento de los hechos y la voluntad de realización de los elementos descritos en el tipo. "El sujeto que actúa con dolo selecciona, con base en los conocimientos que previamente ha adquirido, unos determinados objetivos a los que concede preferencia frente a otros"143, debe representarse el resultado típico. "El dolo, en el concepto de dolo natural, requiere dos elementos: conocimiento y voluntad, de manera que el sujeto debe saber lo que hace y querer hacerlo" ${ }^{144}$.

El dolo se encuentra integrado por un elemento intelectual, que implica un conocimiento del hecho delictivo; y otro volitivo, que es la voluntad del sujeto activo de, aun sabiendo que está prohibido, ejecutar el hecho. Para Sánchez-Vera, "parece que la motivación es un elemento a adicionar al tipo subjetivo, no un elemento para decidir la completa responsabilidad"145. Nuestro Código Penal no requiere un elemento volitivo ni regula las diferentes clases de dolo, sin embargo, su regulación tiende a un enfoque cognitivo del dolo, puesto que lo excluye en los supuestos de error de tipo, dependiendo de la ausencia de conocimiento de los elementos objetivos del tipo por parte del autor ${ }^{146}$.

${ }^{142}$ Ragués i Vallès, R. (1999). El dolo y su prueba en el proceso penal. Barcelona: Bosch, pág. 28.

${ }^{143}$ Díaz Pita, Ma M. (2006). "La presunta inexistencia del elemento volitivo en el dolo y su imposibilidad de normativización”, en Revista penal, nº 17, pág. 67.

${ }^{144}$ FD 4 de la STS 7380/2002, de 7 de noviembre.

145 Sánchez-Vera Gómez-Trelles, J. (2016). "Un reto para el dolo: los motivos del autor", en Derecho Penal para un estado social y democrático de derecho. Estudios penales en homenaje al profesor Emilio Octavio de Toledo y Ubieto. Madrid: Servicio de Publicaciones de la Facultad de Derecho de la UCM, pág. 361.

${ }^{146}$ Sánchez-Málaga, A. (2018). Una teoría para la determinación del dolo: premisas teóricas e indicadores prácticos. Montevideo: B de F, pág. 434. 
Para apreciar dolo no es necesario "el conocimiento de las circunstancias de naturaleza accesoria, ni el conocimiento de la antijuridicidad de la conducta" ${ }^{147}$. Por este motivo, el error invencible excluye la responsabilidad criminal, mientras que si es un error vencible, constituye una conducta imprudente, conforme al art. 14 del Código Penal. "El error de prohibición constituye el reverso de la conciencia de la antijuricidad como elemento constitutivo de la culpabilidad y exige que el autor de la infracción penal ignore que su conducta es contraria a Derecho o, expresado de otro modo, que actúe en la creencia de estar obrando lícitamente" ${ }^{, 148}$. Si el injusto se configura no solo con la infracción de la norma, sino que también incluye una lesión o un peligro para el bien jurídico, el dolo debe implicar el querer o, al menos conocer, esa lesión o peligro $^{149}$. Del mismo modo que el resultado producido por una actuación dolosa no es objetivamente imputable, si el comportamiento externo es objetivamente correcto. "Ello es así porque, entonces, no existe un hecho mínimamente desvalorable al que pueda vincular un juicio de tipicidad un Derecho penal que arranca precisamente del hecho para sus valoraciones y que, por ello, no puede basarlas única y exclusivamente en las intenciones" $" 150$.

En consecuencia y, siguiendo este criterio doctrinal y jurisprudencial, existen varios tipos de dolo, dependiendo de la voluntad del autor del delito:

${ }^{147}$ Romeo Casabona, C. Ma; Sola Reche, E. y Boldova Pasamar, M. Á. (coords.) (2016). Derecho Penal parte general. Introducción a la teoría jurídica del delito. Granada: Comares (2a ed.), pág. 125.

${ }^{148}$ FD 8 de la STS 3486/2012, de 21 de mayo.

149 Modolell González, J. L. (2005). "Consideraciones teóricas sobre la posibilidad de extensión de la imputación objetiva a los delitos de mera actividad", en Bolaños González, M. (compiladora). Imputación objetiva y dogmática penal. Venezuela: Mérida, págs. 245-246.

${ }^{150}$ Gimbernat Ordeig, E. (1985-1986). “Qué es la imputación objetiva?”, en Estudios penales y criminológicos, $\mathrm{n}^{\circ} 10$, pág. 183. 
a) Dolo directo de primer grado: se da cuando el sujeto se propone un fin y predispone los medios para la consecución del mismo, de manera que se encamina directamente a causar de manera voluntaria el resultado típico, es decir, "cuando de manera consciente y querida, la voluntad del sujeto se dirige directamente al resultado propuesto, incluidas las consecuencias necesarias del acto que se asumen"151 "Bajo el concepto de intención o propósito cae lo que el sujeto persigue" ${ }^{, 152}$.

La mayoría de la doctrina asimila el dolo directo a la intención, ya que el sujeto tiene como objeto aquello que se ha propuesto ${ }^{153}$. Este tipo de dolo concurre, por lo tanto, cuando el autor se representa el mayor peligro posible para el bien jurídico y lo ha querido producir directamente con una relación de causalidad ${ }^{154}$.

b) Dolo directo de segundo grado o de consecuencias necesarias: el sujeto sabe que su acción producirá un resultado delictivo determinado, cuya realización no persigue pero se le representa como consecuencia inevitable y él lo sabe: "aunque el autor no quiere directamente el resultado, éste se presenta como una consecuencia natural e inevitable de su acción, que es conocida y admitida por él"155. Abarca "todas las consecuencias que, aunque no las persigue, el sujeto prevé que se producirán con seguridad"156.

\footnotetext{
${ }^{151}$ FD 11 de la STS 6394/2006, de 19 de octubre.

${ }^{152}$ Roxin, C. (1997), op. cit., pág. 415.

${ }^{153}$ Sánchez-Málaga, op. cit., 85.

154 Cuello Contreras, J. (2009). "Dolo e imprudencia como magnitudes graduales del injusto", en Revista de derecho penal y criminología, $\mathrm{n}^{\circ} 2$, pág. 39.

${ }^{155}$ FD 4 de la STS 7380/2002, de 7 de noviembre.

${ }^{156}$ Roxin, C. (1997), op. cit., pág. 415.
} 
La doctrina mayoritaria otorga a este tipo de dolo el mismo tratamiento que al directo, aunque aquí no se requiere la valoración de un elemento volitivo ${ }^{157}$.

c) Dolo eventual: el autor se representa un resultado no seguro pero que acepta como posible ${ }^{158}$, es decir, es suficiente que el autor haya previsto la muerte de otro como una consecuencia probable de su acción y aun así lleva a cabo dicha acción: "surge cuando el sujeto activo se representa como probable la eventualidad de que la acción produzca la muerte del sujeto pasivo, aunque este resultado no sea el deseado, a pesar de lo cual persiste en dicha acción que obra como causa del resultado producido" 159 . "Con dolo eventual actúa quien no persigue un resultado y tampoco lo prevé como seguro, sino que sólo prevé que es posible que se produzca, pero para el caso de su producción lo asume en su voluntad"160.

Atendiendo a su naturaleza, el dolo eventual merece mayor castigo que la culpa pero menor que el dolo directo. "Si reconocemos la categoría dolo eventual, ha de ser a base de fijar para él un concepto y una penalidad intermedias entre el dolo directo y la culpa grave" ${ }^{\text {161 }}$. Para Ragués i Vallès, en estos supuestos no concurre en el sujeto activo la voluntad de realizar el

\footnotetext{
${ }^{157}$ Sánchez-Málaga, op. cit., pág. 86.

${ }^{158}$ La citada sentencia del Supremo 7380/2002, de 7 de noviembre, distingue entre la teoría del consentimiento, en la que el autor "se representa la posibilidad del resultado y consiente o aprueba su producción"; y la teoría de la representación, por la que "se representa el resultado con un alto grado de probabilidad, continuando su acción a pesar de no desearlo directamente (...) Basta con que el autor provoque con su acción, de modo consciente, un riesgo para el bien jurídico que luego no puede controlar".

${ }^{159}$ FD 1 de la STS 4500/2017, de 14 de diciembre.

${ }^{160}$ Roxin, C. (1997), op. cit., pág. 415.

161 Bello Landrove, F. (1998). "El dolo eventual en España", en Jueces para la democracia, nº 32, pág. 16.
} 
tipo penal pero la conducta merece la pena asignada a la infracción dolosa $^{162}$.

A veces esta clase de dolo se confunde con la denominada culpa consciente o culpa con representación, en la que el sujeto, a pesar de que se plantea el resultado como posible, confía en que no se produzca, mientras que en el dolo eventual, acepta esa posible obtención del resultado, actúa independientemente de lo que pueda ocurrir después.

Así lo señala la STS 7260/2008, de 11 de noviembre, en su FD 2:

"La distinción con la culpa consciente o culpa con representación exige introducir un criterio diferenciador, que permita separar los límites de uno y otra.

A) Para la teoría del consentimiento o de la aceptación en el dolo eventual el sujeto aunque no persigue la realización del hecho típico como un fin, ni lo acepta como de necesario advenimiento junto a la consecución del objetivo propuesto, sí "consiente", "acepta", "asume" o "se conforma" según la terminología de los distintos autores- con su eventual producción; mientras que en la culpa consciente el sujeto la rechaza, no se conforma con ello o confía en su no realización. La fórmula para discernir uno u otro supuesto sería no un juicio hipotético de lo que hubiese hecho el sujeto de conocer anticipadamente la certeza del resultado, sino el que atiende a la actuación concreta observada por el sujeto, una vez se ha representado lo eventualmente acaecible: si actuó a toda costa independientemente de la ocurrencia del evento típico hay dolo, pero sí actuó tratando de eludir su ocurrencia habría imprudencia consciente.

B) Para la teoría de la probabilidad, el dolo eventual no requiere ningún elemento volitivo sino sólo el intelectivo o cognoscitivo de la

${ }^{162}$ Ragués i Vallès, op. cit., pág. 49. 
representación del resultado típico como acaecimiento eventual, de modo que si el sujeto actúa considerando ese resultado, no solo como posible sino además como probable, es decir con determinado grado elevado de posibilidad, lo hará con dolo eventual, y si sólo lo considera meramente posible pero improbable, actuará con culpa consciente o con representación, entendiendo como probabilidad algo más que la mera posibilidad aunque menos que probabilidad predominante".

Tanto la ley como la jurisprudencia determinan que, en nuestro derecho penal, respecto al delito de homicidio es irrelevante, a efectos de calificación y penalidad, si se actúa con dolo directo o eventual ${ }^{163}$.

Uno de los temas más debatidos en la doctrina es la intención de matar, el llamado animus necandi, y su diferenciación respecto del animus laedendi o intención de lesionar. La jurisprudencia se ha pronunciado en numerosas resoluciones ${ }^{164}$ sobre "La existencia de dolo de matar hay que deducirla de datos externos y, muy especialmente, del arma empleada y del lugar del cuerpo de la víctima a donde fue dirigida"165. La cuestión surge si un acto genera un peligro para dos bienes jurídicos diferentes pero sin seguridad de lesión para ninguno de ellos, es decir, "cuando la probabilidad de dos resultados de una acción -cualesquiera que estos sean- es idéntica: relevante pero no segura. Puesto que en tales supuestos, resultando subsumible la conducta, desde el punto de vista objetivo, en dos tipos

${ }^{163}$ FD 3 de la STS 5947/2008, de 29 de octubre.

${ }^{164}$ Son múltiples las sentencias en las que el Supremo trata el tema del animus necandi. Un ejemplo claro es la STS 4567/2009, de 25 de mayo, que en su FJ 1 expresa lo siguiente: "la Jurisprudencia de esta Sala viene sosteniendo invariablemente que el tipo subjetivo, es decir la existencia de una voluntad de matar se infiere de la dirección dada por el autor al golpe dirigido contra la víctima. De esta manera, cuando el autor dirigió el golpe con un arma a una parte del cuerpo, que de haber tenido éxito el ataque, podría haber producido la muerte, se considera acreditado que obró con el dolo propio del delito de homicidio"

165 Gimbernat Ordeig, E. (1990). "Algunos aspectos de la reciente doctrina jurisprudencial sobre los delitos contra la vida (dolo eventual, relación parricidioasesinato)", en Jueces para la democracia, $\mathrm{n}^{\circ} 10$, págs. 26-35. 
penales diferentes (...) la subsunción efectiva depende del dolo del sujeto" $" 166$.

Por ejemplo, la STS 6394/2006, de 19 de octubre, concluye en su FJ 10: "la determinación del ánimo homicida constituye uno de los problemas más clásicos del derecho penal, habiendo elaborado esta Sala una serie de criterios complementarios, no excluyentes para en cada caso, en un juicio individualizado riguroso, se puede estimar concurrente o por el contrario, "el animus laedendi o vulnerandi", en una labor inductiva, pues se trata de que el Tribunal pueda recrear, ex post facti, la intención que albergará el agente hacia la víctima, juicio de intenciones que por su propia naturaleza subjetiva solo puede alcanzarlo por vía indirecta, a través de una inferencia inductiva que debe estar suficientemente razonada.

(...) el elemento subjetivo de la voluntad del agente, substrato espiritual de la culpabilidad, ha de jugar un papel decisivo al respecto llevando a la estimación, como factor primordial, del elemento psicológico por encima del meramente fáctico, deducido naturalmente, de una serie de datos empíricos (...) de los que habría que descubrir el ánimo del culpable y ello a pesar de su relatividad y de advertencia de las dificultades derivadas de la circunstancia de la igualdad objetiva y equivalencia del bien jurídico vulnerado en las lesiones consumadas y el homicidio que no transcendió en su ejecución de la forma imperfecta. Las hipótesis de disociación entre el elemento culpabilístico y el resultado objetivamente producido, dolo de matar, por un lado, y mera originación de lesiones, por otro, ha de resolverse llegando a la determinación de si realmente hubo dolo de matar, dolo definido en alguna de sus formas, aún el meramente eventual -que surge cuando el sujeto activo se representa como probable la

\footnotetext{
${ }^{166}$ Paredes Castañón, J.M. (2001) "Problemas metodológicos en la prueba del dolo", en Anuario de filosofía del derecho, $\mathrm{n}^{\mathrm{o}} 18$, págs. 84-85.
} 
eventualidad en que la acción produzca la muerte del sujeto pasivo, aunque este resultado no sea el deseado, a pesar de lo cual persiste en dicha acción que obra como causa del resultado producido-, o la intención del individuo no fue más lejos del "animus laedendi o vulnerandi", sin representación de eventuales consecuencias letales.

El delito de homicidio exige en el agente conciencia del alcance de sus actos, voluntad en su acción dirigida hacia la meta propuesta de acabar con la vida de una persona, dolo de matar que, por pertenecer a la esfera íntima del sujeto, solo puede inferirse atendiendo a los elementos del mundo sensible circundante a la realización del hecho".

Por lo tanto, la diferencia entre un delito de lesiones y un homicidio en grado de tentativa se encuentra "en el ánimo del sujeto, que en uno tiene tan sólo una intención de lesionar y en el otro una voluntad de matar. Es el elemento subjetivo, personal e interno, lo que diferencia que unos hechos aparentemente idénticos puedan juzgarse como lesiones"167.

El homicidio también puede ser culposo, según establece el art. 142 CP: El que por imprudencia grave causare la muerte de otro, será castigado, como reo de homicidio imprudente, con la pena de prisión de uno a cuatro años. El código menciona en concreto la utilización de vehículos a motor o ciclomotores, empleo de arma de fuego o por imprudencia profesional. La mayoría de estos supuestos se producen en prácticas negligentes en el ejercicio de la profesión médica, en el ámbito laboral y en delitos vinculados al tráfico de vehículos.

${ }^{167}$ González Cussac (coord.), op cit., pág. 47. 
Este artículo ha sido modificado en $2019^{168}$, que amplía los supuestos de imprudencia grave a los establecidos en el art. 379, que regula los delitos contra la seguridad vial -circular a velocidad superior a la permitida y conducción bajo los efectos del alcohol o las drogas-. En realidad, este criterio ya se aplicaba y ahora nos encontramos ante una presunción iuris et de iure, por la que los jueces deben calificar como graves los supuestos del art. 379.1 y 2. Los jueces y tribunales tendrán que valorar si dichas circunstancias han provocado el hecho de la muerte y el Supremo diferencia la imprudencia grave y leve, "a partir de la relevancia del deber omitido en función de las circunstancias del caso, teniendo en cuenta el valor de los bienes afectados y la mayor o menor probabilidad de que se produzca el resultado, por un lado, y, por otro, la valoración social del riesgo" $" 169$.

Conforme a lo expuesto por Tamarit Sumalla, con esta reforma tiene especial sentido la aplicación de criterios de imputación objetiva, dado que la jurisprudencia ha tendido a aplicar los criterios en los que la muerte puede atribuirse a la responsabilidad de la víctima. Esta presunción iuris et de iure de imprudencia grave "podrá ser interpretada por los tribunales como una barrera infranqueable a la posible aplicación de criterios de degradación de la gravedad de la imprudencia basados en la responsabilidad de la víctima, si el hecho ha sido provocado por la concurrencia de alguna de las circunstancias del art 379 en el comportamiento del acusado", lo que no impide "la aplicación de criterios de imputación objetiva que lleven a la negación de la tipicidad del hecho, si

\footnotetext{
${ }^{168}$ Ley Orgánica 2/2019, de 1 de marzo, de modificación de la Ley Orgánica 10/1995, de 23 de noviembre, del Código Penal, en materia de imprudencia en la conducción de vehículos a motor o ciclomotor y sanción del abandono en el lugar del accidente.

169 Tamarit Sumalla, J. M (2019). "El nuevo tratamiento legal de la imprudencia y el delito de abandono en el lugar del accidente", en Quintero Olivares, G., et al., Las Reformas Penales de 2019. Navarra: Thomson Reuters Aranzadi, pág. 20.
} 
el juez o tribunal concluye que el resultado de muerte no es consecuencia de la realización del riesgo contenido en la acción imprudente del autor" ${ }^{\text {"170 }}$.

También se añade un párrafo en el apartado 2, sobre la imprudencia menos grave: Se reputará imprudencia menos grave, cuando no sea calificada de grave, siempre que el hecho sea consecuencia de una infracción grave de las normas sobre tráfico, circulación de vehículos a motor y seguridad vial, apreciada la entidad de ésta por el Juez o el Tribunal. Según este artículo, se exige que el resultado sea consecuencia de la infracción, es decir, que la muerte "represente la realización del riesgo real contenido en la acción u omisión típica""171.

Por último, se ha introducido un nuevo art. 142 bis, que permite al Juez o Tribunal imponer motivadamente la pena superior en un grado, en la extensión que estime conveniente, si el hecho revistiere notoria gravedad, en atención a la singular entidad y relevancia del riesgo creado $y$ del deber normativo de cuidado infringido, y hubiere provocado la muerte de dos o más personas o la muerte de una y lesiones constitutivas de delito del artículo 152.1.2. ${ }^{\circ}$ o $3 .^{\circ}$ en las demás, y en dos grados si el número de fallecidos fuere muy elevado. Con esta modificación se ha pretendido aumentar la sanción para hechos especialmente graves que producen la muerte, sobre todo si el conductor se encuentra bajo los efectos del alcohol o sustancias estupefacientes, además de incluir el delito de abandono en el lugar del accidente, con una redacción autónoma, al interpretarlo como una conducta independiente y distinta de la conducta previa que sea imprudente o fortuita. La Exposición de Motivos de la Ley lo justifica para sancionar la maldad intrínseca en el abandono de quien sabe que deja atrás a alguien que pudiera estar lesionado o incluso

\footnotetext{
${ }^{170}$ Ibid., pág. 21.

${ }^{171}$ Ibid., pág. 24.
} 
fallecido, la falta de solidaridad con las víctimas, penalmente relevante por la implicación directa en el accidente previo al abandono, y las legítimas expectativas de los peatones, ciclistas o conductores de cualquier vehículo a motor o ciclomotor, de ser atendidos en caso de accidente de tráfico. Se busca evitar el concurso de normas entre este tipo penal y el delito de omisión del deber de socorro (...) refiriéndolo a los casos de personas que sufran lesiones graves pero en las que no concurran los requisitos del peligro manifiesto y grave que exige la omisión del deber de socorro.

Los elementos del delito culposo son tres:

a) La acción sin diligencia debida ${ }^{172}$ : una conducta en la que el autor del hecho haya infringido el deber de cuidado exigible en el desarrollo del acto: "acción u omisión llevada a efecto con inobservancia de normas, disposiciones o reglas de cautela, diligencia y prudencia, requeridas por las circunstancias del hecho". Para considerar cuál es ese deber de cuidado, hay que observar el deber que cualquier persona en la posición del autor y con sus conocimientos y experiencias tenía y podía haber observado, es decir, la capacidad individual de cada autor en la situación específica exigible ${ }^{173}$. El propio fundamento de la sanción se busca precisamente en ese elemento de infracción del

\footnotetext{
172 "En la doctrina actual la idea central en materia de imprudencia punible gira alrededor de un concepto esencial: la infracción de un deber de cuidado. Si como consecuencia de tal infracción se produce un resultado previsto por un precepto concreto de la ley como infracción penal por imprudencia, nos encontramos ante el delito o falta" -la sentencia es anterior a la entrada en vigor de la reforma del CP que derogó las faltas- "de esa clase. Cuando tal resultado es la muerte de una persona, si la imprudencia es grave, estamos ante el delito del art. 142 CP". (FD 4 de la STS $1329 / 2001$, de 5 de septiembre).

${ }^{173}$ Del Río Montesdeoca, L. (2017). Los delitos de homicidio y lesiones imprudentes en el ámbito laboral. Valencia: Tirant lo Blanch, pág. 21.
} 
deber de cuidado, por el desvalor de la conducta de esa infracción $^{174}$.

b) Previsibilidad objetiva y subjetiva: que esa conducta produzca un resultado previsible y evitable: "realidad acreditada del evento perjudicial sobrevenido, como consecuencia de la negligente conducta observada por el sujeto activo en su doble vertiente intelectiva de falta de previsión «o deber saber», y objetiva de falta de cuidado «o deber evitar»".

La exigencia de la previsibilidad desde el punto de vista objetivo requiere que el sujeto activo sea cuidadoso con un riesgo que sea objetiva y generalmente peligroso, como por ejemplo, manejar armas de fuego, conducir un vehículo, etc. "Si a pesar de conocer la peligrosidad abstracta de su actuación una persona no hace nada para controlar su lesividad o decide realizar igual la actividad esa persona estará infringiendo su deber de cuidado" ${ }^{\text {175 }}$. En estos casos el infractor no respondería aunque haya podido evitar el resultado si este entra dentro de lo jurídicamente permitido, "si el riesgo es jurídica y socialmente tolerado no hay delito"176.

c) Producción de la muerte: que el resultado se genere como consecuencia de la falta de cuidado que se exige al sujeto que realiza la acción: "que la actuación culposa reprochable penalmente pueda imputarse a sujeto personalmente determinado, al darse una relación directa de causalidad, o sea, por existir un nexo causal indubitado entre la acción u omisión ejecutada y el daño concreto ocasionado".

\footnotetext{
${ }^{174}$ Pérez del Valle, C. (2012). La imprudencia en el derecho penal: el tipo subjetivo del delito imprudente. Barcelona: Atelier, pág. 78.

${ }^{175}$ Feijóo Sánchez, B. (1999). Homicidio y lesiones imprudentes: requisitos y límites materiales. Zaragoza: EDIJUS, págs. 191-192.

176 Tamarit Sumalla, op. cit., pág. 24. 
Otro ejemplo de jurisprudencia del Tribunal Supremo lo encontramos en la STS 2632/2002, de 15 de abril, en la que se determinó que la imprudencia exige:

“a) una acción u omisión voluntaria no maliciosa;

b) una infracción del deber de cuidado;

c) un resultado dañoso derivado, en adecuada relación de causalidad, de aquella descuidada conducta, y

d) la creación de un riesgo previsible y evitable".

También dice que "la imprudencia viene integrada por un «elemento psicológico» (que consiste en el poder y facultad humana de previsión y que se traduce en la posibilidad de conocer y evitar el evento dañoso) y un «elemento normativo» (representado por la infracción del deber de cuidado) (...) La relación de causalidad a que se ha hecho mención ha de ser directa, completa e inmediata, así como eficiente y sin interferencias".

Siguiendo a Calderón Tello, "en los delitos imprudentes debe estar presente la concreta obligación de evitar que el resultado se produzca. Es necesario que el autor se encuentre en una situación de la que derive necesariamente el concreto deber de evitar el resultado prohibido, se debe estar en posición de garante"177.

\subsubsection{Homicidio agravado.}

La reforma de 2015 introduce un apartado segundo en el art. 138, donde se regula el homicidio cualificado, que se castiga con la pena superior en

177 Calderón Tello, L. F. (2016). Ensayo acerca del tipo culposo o imprudente en derecho penal y su relación con la imputación objetiva. Navarra: Thomson ReutersAranzadi (1 $1^{\text {a }}$ ed. $)$, pág. 73. 
grado a la prevista para el tipo básico, es decir, prisión de quince años y un día a veintidós años y seis meses:

2. Los hechos serán castigados con la pena superior en grado en los siguientes casos:

a) cuando concurra en su comisión alguna de las circunstancias del apartado 1 del artículo 140, o

b) cuando los hechos sean además constitutivos de un delito de atentado del artículo 550.

Cuatro son los supuestos de homicidio agravado, los tres primeros coincidentes con la agravación del asesinato, que veremos también en el apartado correspondiente:

- Víctima menor de dieciséis años o especialmente vulnerable por su edad, enfermedad o discapacidad.

- Homicidio subsiguiente a un delito contra la libertad sexual. Llama la atención que no se haga referencia a los delitos contra la indemnidad sexual, ya que afectan a las víctimas menores de edad, ${ }^{178}$ aunque en estos casos podría interpretarse como incluido dentro de la circunstancia de edad o vulnerabilidad de la víctima ${ }^{179}$.

- Cometido en el seno de un grupo u organización criminal.

- Delito de atentado.

\footnotetext{
${ }^{178}$ Esquinas Valverde, P. (2018) "El homicidio y sus formas", en Marín de Espinosa Ceballos, E. (dir.) y Esquinas Valverde, P. (coord.). Lecciones de Derecho penal. Parte especial. Valencia: Tirant lo Blanch, pág. 34.

${ }^{179}$ Felip i Saborit, D. (2018). "El homicidio y sus formas", en Silva Sánchez, J. Ma (dir.) y Ragués i Vallès, R. (coord.). Lecciones de derecho penal. Parte especial. Barcelona: Atelier ( $5^{\mathrm{a}}$ ed.), pág. 34.
} 
Para Alonso Álamo, esta categoría intermedia entre homicidio y asesinato "parece más adecuada a sistemas legales que carezcan de circunstancias generales, como el Código penal francés o el Código penal alemán" "180. Otros autores, como Peñaranda Ramos, critican que "el establecimiento de hasta cinco regímenes jurídicos diferentes para los homicidios dolosos contrasta con la tendencia a la simplificación que se observa en los más recientes movimientos de reforma de los delitos contra la vida en el Derecho comparado"181.

La primera circunstancia, víctima menor de dieciséis años o especialmente vulnerable, existe de manera similar en el derecho francés y portugués aunque no es exactamente coincidente con la regulada en nuestro ordenamiento. La vida de todos se protege por igual pero en esta modificación se ha tenido en cuenta "la necesidad de proteger adicionalmente el interés a la igualdad real de las personas que se hallan en situación de desventaja" ${ }^{2182}$, divididas en dos grupos. Por una parte, los menores de dieciséis años, donde habría que considerar las diferencias entre un recién nacido, en cuyo caso esta circunstancia ya se califica como alevosa y conllevaría aplicar una pena de homicidio agravado en lugar de un asesinato alevoso, o alguien que tenga capacidad defensiva, situación en la que, si el autor emplea medios para evitar la defensa de la víctima y asegurar la ejecución, se podría aplicar la alevosía y la minoría de edad sin vulnerar el principio non bis in idem dado que las dos circunstancias tienen un ámbito y naturaleza jurídica propia ${ }^{183}$.

\footnotetext{
${ }^{180}$ Alonso Álamo, M. (2015). “La reforma...”, op. cit., pág. 18.

${ }^{181}$ Peñaranda Ramos, E. (2016). "Los delitos de homicidio y asesinato tras la reforma de 2015 del Código Penal", en Estudios de Derecho Penal: homenaje al profesor Miguel Bajo. Madrid: Ramón Areces, pág. 1259.

182 Alonso Álamo, M. (2015). “La reforma...”, op. cit., pág. 19.

${ }^{183}$ Ibid., pág. 21.
} 
Según Peñaranda Ramos, podría ser conveniente una "interpretación restrictiva del alcance de esta circunstancia agravante específica o cualitativa del homicidio y exigir, para apreciar su concurrencia en todos los casos (...) que se hubiese dado un abuso o aprovechamiento de la especial vunerabilidad de la víctima" ${ }^{\text {184 }}$.

Respecto al sujeto pasivo especialmente vulnerable, la vulnerabilidad debe estar acreditada y, tanto la minoría de edad comentada, como la vejez, la enfermedad o la discapacidad han de producir la vulnerabilidad que justifique la aplicación de la circunstancia agravante. Al no existir la definición concreta de "vulnerabilidad", cabe plantearse si esta es compatible con la capacidad de defensa de la víctima. Nuevamente existe la posibilidad de aplicar la alevosía porque la víctima pueda tener cierta capacidad de defensión (por ejemplo con determinadas discapacidades psíquicas). Felip i Saborit afirma que esta última modalidad "a menudo se verá desplazada en aplicación de la doctrina jurisprudencial de los seres indefensos por el asesinato por alevosía" ${ }^{\prime 185}$.

Por lo tanto, la muerte producida a una persona completamente incapaz de defenderse (recién nacido, tetrapléjico) supone un homicidio agravado, según esta nueva regulación, mientras que en los casos de menores o especialmente vulnerables pero capaces de defenderse, se considera asesinato alevoso. Así, se vacía parte del contenido de la alevosía por desvalimiento de la víctima aunque subsiste la alevosía por desvalimiento sobrevenido por otras razones que no sean la edad, enfermedad o discapacidad ${ }^{186}$.

\footnotetext{
${ }^{184}$ Peñaranda Ramos, E. (2016). "Los delitos de homicidio...”, op. cit., pág. 1264.

${ }^{185}$ Felip i Saborit, op. cit., pág. 34.

${ }^{186}$ Alonso Álamo, M. (2015). “La reforma...”, op. cit., pág. 24. 
Acerca de la segunda de las circunstancias enumeradas en el 138.2, hecho subsiguiente a un delito contra la libertad sexual sobre la víctima, se fundamenta en el mayor desvalor de resultado, por la pluralidad de delitos y de bienes jurídicos vulnerados. Aunque hay una regulación parecida en el derecho comparado, en la legislación española no se contempla la conexión causal ni teleológica entre los dos delitos, como sí ocurre, por ejemplo en el código italiano. Lo mismo sucede con el ámbito de aplicación, ya que se refiere a un delito "subsiguiente", mientras que en el derecho francés se habla del homicidio que precede, acompaña o sigue a otro delito. Por tanto, no se aplicaría si el homicidio es cometido durante el delito contra la libertad sexual, debido por ejemplo a la violencia empleada.

Por ese motivo cabe la duda de cómo aplicar las reglas del concurso real entre el homicidio y el delito sexual para no vulnerar el principio non bis in idem. Para que sea compatible, debe entenderse este tipo como un delito complejo, a pesar de que esto provoca que, si el delito sexual es grave, se esté privilegiando al homicida, ya que la regla del concurso real conllevaría mayor pena, mientras que si el delito sexual es menos grave, esta agravante puede suponer una pena desproporcionada ${ }^{187}$.

Peñaranda Ramos afirma que no tiene sentido para el homicidio, si se está pensando en casos particularmente graves de producción de la muerte en un contexto de violencia sexual, pues para eso ya se hace en relación con el delito de asesinato, que conlleva mayor pena ${ }^{188}$.

En el caso de la pertenencia a organización o grupo, para Alonso Álamo ${ }^{189}$, se plantea el problema de tratar como una circunstancia un fenómeno de pluralidad delictiva que debería dar lugar a un concurso de

\footnotetext{
${ }^{187}$ Esquinas Valverde, op. cit., pág. 35.

${ }_{188}$ Peñaranda Ramos, E. (2016). “Los delitos de homicidio...”, op. cit., pág. 1266.

189 Alonso Álamo, M. (2015). “La reforma...”, op. cit., pág. 29.
} 
delitos y, con esta inclusión, el homicidio o asesinato agravados cierran el paso a la apreciación de dicho concurso.

El atentado es una circunstancia exclusiva del homicidio agravado, no así del asesinato. En el derecho comparado el fundamento de la agravación se encuentra en la condición del sujeto pasivo y aquí se remite al delito de atentado, entendido por tal a quien agreda a la autoridad, a sus agentes o funcionarios públicos, así como los funcionarios docentes o sanitarios, todos ellos cuando se encuentren en el ejercicio de sus cargos. Lo que se pretende es proteger "el correcto desenvolvimiento de las funciones púbicas, bien jurídico protegido a través del delito de atentado" 190 . Cuando existe pluralidad de acciones que dan lugar a un delito de atentado, como sucesivas agresiones, concurren pluralidad de actos y unidad de acción y se puede apreciar esta circunstancia agravatoria, no así en los casos en los que hay varias acciones y distintos sujetos pasivos (muerte de uno y lesiones de otro, por ejemplo). Entonces entraríamos en las reglas del concurso real de homicidio y atentado, por un lado, y, por otro, lesiones y atentado en concurso ideal ${ }^{191}$.

Esto incluye tanto el tipo básico del art. 550 (agresión con intimidación grave o violencia u oposición de resistencia grave), como en el agravado del 551 aplicable a los siguientes casos:

- utilización de armas u otros objetos peligrosos,

- cuando el acto de violencia resulte potencialmente peligroso para la vida de las personas o pueda causar lesiones graves, por ejemplo, a través del lanzamiento de objetos contundentes

\footnotetext{
190 Javato Martín, A. M (2005). El delito de atentado. Modelos legislativos. Estudio histórico-dogmático y de Derecho comparado. Granada: Comares, citado por Alonso Álamo, M. (2015). "La reforma...", op. cit., pág. 31.

${ }^{191}$ Alonso Álamo, M. (2015). "La reforma...”, op. cit., pág. 32. 
o líquidos inflamables, el incendio y la utilización de explosivos,

- con uso de un vehículo de motor para acometer a la víctima,

- si los hechos tienen lugar como consecuencia de un motín, plante o incidente colectivo en el interior de un centro penitenciario.

No obstante, la doctrina cuestiona la inclusión en este tipo de homicidio agravado, de los sujetos del art. 554 (bomberos, equipos de socorro y personal de seguridad privada, todos ellos ejerciendo sus funciones) y entiende que esta agravante no abarca esos supuestos ${ }^{192}$.

\subsection{El asesinato.}

Regulado en el art. 139 CP, que dispone lo siguiente:

1. Será castigado con la pena de prisión de quince a veinticinco años, como reo de asesinato, el que matare a otro concurriendo alguna de las circunstancias siguientes:

1. ${ }^{a}$ Con alevosía.

2. ${ }^{a}$ Por precio, recompensa o promesa.

3. ${ }^{a}$ Con ensañamiento, aumentando deliberada e inhumanamente el dolor del ofendido.

4. ${ }^{a}$ Para facilitar la comisión de otro delito o para evitar que se descubra ${ }^{193}$.

\footnotetext{
192 Ibid., pág. 30.

${ }^{193}$ Esta circunstancia, sin tradición en nuestro ordenamiento, ha sido tomada del Código Penal alemán. Muñoz Conde, F. (2016). "El delito de asesinato tras la reforma penal del 2015”, en Cuestiones penales. A propósito de la Reforma penal de 2015. Madrid: Dykinson, pág. 23.
} 
2. Cuando en un asesinato concurran más de una de las circunstancias previstas en el apartado anterior, se impondrá la pena en su mitad superior.

Al interpretar este segundo apartado del artículo, la mayoría de la doctrina entiende que la primera circunstancia califica el asesinato del 139.1 y, si concurre otra más, se aplica el supuesto agravado del 139.2. La tercera se consideraría agravante genérica, que llevaría al tribunal sentenciador a imponer la pena de entre veinte y veinticinco años en su mitad superior ${ }^{194}$.

Según Silva Sánchez, esta mayor gravedad se basa en parte en que el asesino "manifiesta una actitud interna especialmente reprobable" $" 195$; la alevosía implica un mayor contenido del injusto; en el ensañamiento se muestra un especial desprecio a la vida y la dignidad humana; y en el precio es el propio móvil del crimen lo que es sustancialmente reprochable.

Algunos sectores doctrinales mantienen que el asesinato es un delito autónomo, mientras que otros lo consideran como un homicidio cualificado, como ocurre en algunos países de Europa, distinción que vimos con más detalle en el apartado sobre derecho comparado. Entre los primeros se encuentran Muñoz Conde ${ }^{196}$ o Martos Núñez, mientras que entre los segundos está del Rosal Blasco ${ }^{197}$. La mayoría de la doctrina

\footnotetext{
${ }^{194}$ Serrano Gómez, A., et al. (2016). Curso de Derecho Penal parte especial. Madrid: Dykinson, pág. 28.

195 Silva Sánchez, op. cit., pág. 32.

196 "La muerte de una persona a consecuencia de la acción realizada por otra, valiéndose de medios peligrosos o revelando una especial maldad o peligrosidad, ha sido tradicionalmente castigada más severamente que el simple homicidio, constituyendo el delito llamado asesinato; delito autónomo y no un mero homicidio cualificado". Muñoz Conde citado por Martos Núñez (2017), op.cit., pág. 25.

197 Entiende que el asesinato, basado en el mayor reproche imputable al autor si concurre cualquiera de las circunstancias que lo califican, desde los anteriores códigos ha alterado tanto su naturaleza que ya no cabe considerarlo como figura independiente, con sustantividad propia respecto del homicidio. Para este autor, la rúbrica del Título I
} 
aboga por un delito independiente porque las circunstancias que lo califican "no son meras circunstancias modificativas de lo que sería la pena-base (la del homicidio), sino que están hasta tal punto incrustadas en la figura del delito que han perdido su función modificativa de la pena para pasar a ser auténticos elementos integrantes de su estructura" ${ }^{\text {198 }} \mathrm{y}$, por lo tanto, no son simplemente circunstancias agravantes genéricas sino que son las que integran el tipo penal del asesinato, más grave que el del homicidio. La rúbrica del Título provoca unas consecuencias interpretativas "que de ahí se han derivado en orden a negar la autonomía del asesinato" y se introduce mayor complejidad al distinguir dos clases de homicidio (simple y agravado) y tres de asesinato (simple, agravado e hiperagravado), al incorporar unas circunstancias de agravación "cuya presencia apenas se molesta en justificar el legislador"199.

Estas circunstancias "no son meras circunstancias accidentales del delito, sino constitutivas del mismo como elementos esenciales de la figura correspondiente, por ser mayor lo injusto y/o la culpabilidad" y presenta una "autonomía estructural" 200 .

En un principio, no se incluyó el término "asesinato" en el proyecto y finalmente se mantuvo para conservar la tradición de los códigos penales anteriores, como ya hemos visto, sin más consecuencias dogmáticas. La voluntad del legislador fue someter las circunstancias del asesinato "al

del Libro II del CP "Del homicidio y sus formas" otorga seguridad jurídica y mantener el término asesinato es más una cuestión de tradición de naturaleza simbólica "pero sin más consecuencias dogmáticas”. Del Rosal Blasco citado por Martos Núñez, Ibid., págs. 26 y 27.

${ }_{198}$ Martos Núñez, J. A., Ibid., pág. 31.

199 Sanz Morán, Á. J. (2016) "La reforma de los delitos contra la vida", en Derecho Penal para un estado social y democrático de derecho. Estudios penales en homenaje al profesor Emilio Octavio de Toledo y Ubieto. Madrid: Servicio de Publicaciones de la Facultad de Derecho de la UCM, pág. 828.

${ }^{200}$ Romeo Casabona, C. Mª Sola Reche, E. y Boldova Pasamar, M. Á. (coords.) (2016). Derecho Penal parte especial. Conforme a las Leyes Orgánicas 1 y 2/2105, de 30 de marzo. Granada: Comares, pág. 24. 
régimen general sobre comunicabilidad y error, propio de las circunstancias modificativas de la responsabilidad"201.

Para Sanz Morán, siguiendo el criterio de Liszt, Artz y Torío, la pena más grave del ordenamiento se debe reservar para las formas más graves de ataque a la vida humana independiente. "Pero sólo si esa pena difiere cualitativamente (como sucede con la pena de muerte o la de reclusión perpetua) de las que le siguen en la escala de gravedad, cobra sentido la separación conceptual entre homicidio y asesinato, entendidas como modalidades delictivas autónomas. Si, por el contrario, renunciamos a las penas de muerte y reclusión perpetua, existiendo entonces una única pena privativa de libertad temporal, graduable según su mayor o menor duración, se flexibilizará notablemente la construcción legislativa de diversas modalidades, más o menos graves, de un único delito de homicidio doloso" 202 .

Según el Supremo, sí se considera el asesinato como delito autónomo respecto al homicidio y se diferencian ambas figuras delictivas, las agravaciones del $139 \mathrm{CP}$ "a partir de su inclusión en el tipo del asesinato, no serían meras circunstancias de agravación, sino que integrarían elementos del tipo del asesinato (...). Se trataría de elementos del delito cuya concurrencia en la conducta determinaría una distinta tipicidad, más grave que la del homicidio (...) Sin embargo, tras la entrada en vigor del nuevo Código penal es más adecuada la consideración del asesinato como delito dependiente del homicidio, como forma agravada del homicidio"203.

Algunas de las novedades de la reforma que entró en vigor el 1 de julio de 2015 -vigesimoséptima reforma desde que el código se aprobó en

${ }^{201}$ López Garrido, D. y García Arán, M. (1996). El Código Penal de 1995 y la voluntad del legislador. Madrid: EUROJURIS, pág. 86.

${ }^{202}$ Sanz Morán (1995), op. cit., pág. 799.

${ }^{203}$ FD 2 de la STS 7251/2002, de 31 de octubre. 
1995, modificado por la LO 1/2015, de 30 de marzo- han sido aumentar el máximo de la pena del asesinato, de los veinte a los veinticinco años, además de añadir la cuarta de las circunstancias expresadas en el art. 139.

Según el 140 bis, a los condenados por la comisión de uno o más delitos comprendidos en este Título se les podrá imponer además una medida de libertad vigilada.

El asesinato tiene varios elementos en común con el homicidio, como es el sujeto activo y pasivo, el objeto material y la vida como el bien jurídico protegido, sin embargo, la gran diferencia radica en el tipo subjetivo, ya que el asesinato nunca puede cometerse por imprudencia, debido a que las propias circunstancias de su comisión lo hacen imposible. Además de existir la intención de matar, se utilizan medios que tienden, de manera clara, a provocar esa muerte y que se exponen a continuación.

\subsubsection{La alevosía.}

La alevosía no solo es típica de esta figura sino que está contemplada como una de las circunstancias agravantes generales reguladas en el art. 22, en su apartado $1^{\circ}$ y así, según el $\mathrm{CP}$, hay alevosía cuando el culpable comete cualquiera de los delitos contra las personas empleando en la ejecución medios, modos o formas que tiendan directa o especialmente a asegurarla, sin el riesgo que para su persona pudiera proceder de la defensa por parte del ofendido. Su gravedad se basa en la mayor peligrosidad objetiva de un atentado a la vida realizado con la concurrencia de esta circunstancia, por eso no se aprecia alevosía cuando hay una agresión previa por parte del ofendido, ni una defensa activa por su parte, pero sí se puede apreciar 
cuando exista "una defensa pasiva, autoprotección o defensa dentro del marco del instinto de conservación por parte de la víctima" ${ }^{204}$.

Este factor requiere que el sujeto, al realizar la agresión, utilice medios, modos o formas en su ejecución que objetivamente produzcan la indefensión de la víctima y sin que exista un riesgo para el autor del hecho. El desvalor de la conducta se justifica porque el agresor idea un plan para obtener una superioridad sobre la víctima y esas circunstancias que le garantizan el resultado buscado producen que sea merecedor de un mayor reproche penal ${ }^{205}$. Por lo tanto, se exige que el empleo de los medios sea voluntario, lo que implica la actitud propia del dolo ${ }^{206}$.

No es necesario que estos medios, modos o formas sean buscados por el autor, sino que es suficiente que se aproveche de ellos ${ }^{207}$. A este respecto se pronuncia, por ejemplo la STS 2370/2018, de 19 junio, en su FD 4. Razona la existencia de alevosía en base a cuatro elementos:

- Un elemento normativo, puesto que solo puede proyectarse a los delitos contra las personas.

- Un elemento objetivo o instrumental, que implica asegurarse la muerte sin el riesgo del que la ocasiona, elemento esencial de la alevosía, "que el autor utilice en la ejecución medios, modos o formas que han de ser objetivamente adecuados para asegurarla

204 Arias Eibe, M. J. (2005) "La circunstancia agravante de alevosía. Estudio legal, dogmático-penal y jurisprudencial", en Revista Electrónica de Ciencia Penal y Criminología, $\mathrm{n}^{\circ} 7$, pág. 5.

${ }^{205}$ Gómez Rivero, C. (2000). "Presupuestos y límites de la alevosía y el ensañamiento en el Código Penal”, en Revista de derecho y proceso penal, $\mathrm{n}^{\circ} 4$, pág. 37.

206 Ibid., pág. 40.

207 Cuello Calón, E. (1975). Derecho Penal. Tomo II (Parte Especial), Vol. 2. Barcelona: Bosch (2 $2^{\mathrm{a}}$ ed.), pág. 506. 
mediante la eliminación de las posibilidades de defensa ${ }^{208}$, sin que sea suficiente el convencimiento del sujeto acerca de su idoneidad".

- Un elemento subjetivo o culpabilístico, "denotando de manera inequívoca el propósito del agente de utilizar todos los medios con la debida conciencia e intención de asegurar la realización del delito, eludiendo todo riesgo personal, de modo que al lado de la antijuricidad, ha de apreciarse y valorarse la culpabilidad"209. Este consiste en que el dolo del autor se proyecte también "sobre su tendencia a asegurar la ejecución y su orientación a impedir la defensa del ofendido, eliminando así conscientemente el posible riesgo que pudiera suponer para su persona una eventual reacción defensiva de aquél". Es decir, una manera de actuar especialmente cobarde y traicionera en la que el autor se aprovecha de la situación «para asegurarse el resultado sin riesgo para él.

- Un elemento teleológico, que "impone la comprobación de si en realidad, en el caso concreto, se produjo una situación de total indefensión, siendo necesario que se aprecie una mayor antijuricidad en la conducta derivada precisamente del modus operandi, conscientemente orientado a aquellas finalidades".

En resumen, que en la alevosía se realiza la agresión de manera que la víctima no se pueda defender, lo que asegura la ejecución del delito sin riesgo para el autor, lo que no significa que no se aprecie en los supuestos de intento de defensa "cuando es funcionalmente imposible, y se debe a la

\footnotetext{
${ }^{208}$ Con esta expresión el TS da a entender que la situación de indefensión proceda del mismo ataque que el agresor utiliza contra la víctima y no de otra circunstancia ajena. ${ }^{209}$ FD 4 de la STS 7816/2009, de 13 de noviembre.
} 
reacción instintiva de quien no tiene escapatoria frente a la eficacia de un ataque ejecutado sobre seguro" ${ }^{, 10}$.

Respecto a los modos, medios o formas de los que se vale el autor para garantizar el resultado y evitar su propio riesgo, la doctrina del Tribunal Supremo ${ }^{211}$ distingue tres clases de alevosía:

- la proditoria, aleve o traicionera, cuando el ataque se realiza a traición, por la espalda o con ocultación de la intención homicida o del propio autor. Se obra "en emboscada o al acecho a través de una actuación preparada para que el que va a ser la víctima no pueda apercibirse de la presencia del atacante o atacantes hasta el momento mismo del hecho".

- la súbita o inopinada, también llamada sorpresiva, cuando el sujeto realiza un ataque repentino, con la víctima totalmente desprevenida, de manera que, aunque el agresor no se oculte físicamente, no pueda prever su acción ni reaccionar para intentar defenderse. "Cuando el agredido, que se encuentra confiado con el agresor, se ve atacado de forma rápida e inesperada".

- de aprovechamiento de una especial situación de desvalimiento como consecuencia de la particular condición de la víctima, bien por ser una persona especialmente indefensa, como en el caso de niños, ancianos o enfermos; o por estar la víctima temporalmente privada de aptitud para defenderse: dormida, privada de razón, drogada o ebria.

Por este motivo, la jurisprudencia entiende que, cuando la víctima es un niño, hay que considerar siempre la circunstancia de la alevosía. Entre

${ }^{211}$ FD 2 de la STS 2563/2010, de 14 de mayo, entre otras. 
otras, la STS 3840/2006, de 28 de abril, en su FD 2, "La claridad de la alevosía, vista la corta edad del niño, la privación de cualquier medio de defenderse (...) la imposibilidad de cualquier defensa es tan evidente, que la jurisprudencia ya ha declarado reiteradamente que la muerte de un niño es siempre alevosa".

$\mathrm{Su}$ fundamento se basa en el desequilibrio de fuerzas existente entre el autor y la víctima, para garantizar que no se produzca una reacción por parte de esta última, sin embargo, parte de la doctrina plantea dudas acerca de estos casos, debido a si habría que considerar la alevosía cuando el autor se aprovecha de esa circunstancia aunque no la haya provocado él, es decir, que ni siquiera tenga que realizar alguna acción adicional que anule la posible defensa de la víctima ${ }^{212}$.

Además, la jurisprudencia señala que es compatible con el dolo eventual porque es diferenciable "una directa y decidida intención y voluntad de dar cumplimiento a finalidades aseguratorias para la ejecución y para el propio actuante así como sobre la indefensión de la víctima (...) de una actitud intencional que no completa el agotamiento de la determinación de dañar respecto a la causación del daño o lesión en sí misma en cuanto a la aceptación de su resultado"213.

La doctrina concuerda con esta corriente jurisprudencial, de modo que la alevosía puede relacionarse tanto con el dolo directo como con el eventual, respecto a la muerte, aunque en cuanto a los medios, modos y formas de cometerlo, solamente cabe dolo directo, por la concurrencia del elemento subjetivo trascendente ${ }^{214}$.

\footnotetext{
${ }^{212}$ Gómez Rivero, op. cit., pág. 42.

${ }^{213}$ FD 14 de la STS 6348/2011, de 21 septiembre.

${ }^{214}$ Mapelli Caffarena, op. cit., pág. 443.
} 


\subsubsection{Precio, recompensa o promesa.}

La génesis de esta circunstancia se encuentra en el derecho romano, al considerar que existe una mayor gravedad en el hecho de matar a alguien a cambio de algo con valor económico. Exige tres presupuestos:

- Que se realice un ofrecimiento por ejecutar el asesinato.

- Que ese ofrecimiento sea aceptado, independientemente de si, por alguna circunstancia, al final no se obtiene. Solo tiene que llevar al autor a cometer el delito por ese motivo. Silva Sánchez et al. manifiestan que "no es necesario que se haya efectuado pago o contraprestación alguna sino que basta con que el autor obre impulsado por una oferta realizada por un tercero, normalmente el inductor del delito" ${ }^{, 215}$.

- Que el beneficio económico se reciba por el hecho de matar y no por el de que se produzca la muerte. Es precisamente ese hecho el que conlleva mayor gravedad, ya que se mata por interés, por un mero móvil económico y quien lo realiza no obtiene el beneficio con la muerte sino por matar. $^{216}$. Esto diferencia los casos en los que alguien cobra para ejecutar el asesinato de los que cometen un homicidio por ejemplo para obtener una herencia. Este último supuesto, no se considera incluido dentro de este tipo penal.

También es requisito imprescindible que la muerte se lleve a cabo motivado por ese incentivo ofrecido y no que ya existiera previamente en el autor un ánimo de matar al sujeto pasivo antes de recibirlo. Por eso es necesario que el concierto del precio sea hecho antes de la ejecución del delito, aunque posteriormente no lo reciba, ya que el incremento de su

\footnotetext{
215 Silva Sánchez, op. cit., pág. 35.

216 González Rus, J. J. et al. (1996), en Curso de Derecho Penal Español. Parte Especial I. Madrid: Marcial Pons, pág. 69.
} 
gravedad reside en el aumento de culpabilidad que tiene el autor por esa motivación, al ser un móvil lucrativo. "La doctrina dominante sostiene que la comisión de un delito mediante precio, recompensa o promesa se fundamenta en la motivación económica que preside el comportamiento del sujeto activo y, por tanto, es de índole personal". Por eso autores como Cobo del Rosal, Vives Antón y Rodríguez Devesa consideran que la circunstancia es de naturaleza subjetiva porque el fundamento de la causa de agravación reside en ese ánimo de lucro ${ }^{217}$. Su fundamento "reside en el doble hecho de lo inesperado del ataque viniendo de un desconocido y en la dificultad de establecer el móvil"218. Hay que concebir la circunstancia como un elemento de la culpabilidad previsto por la ley en el tipo para agravar el homicidio $^{219}$.

La cantidad económica no es relevante, sino que lo esencial es que el asesinato se cometa "sin motivo propio y que lo que mueva a esa persona a matar sea la obtención de un lucro por el mero hecho de matar"220. A juicio de algunos autores, no solamente hay que tener en cuenta la motivación exclusivamente económica del autor, sino que el fundamento de la agravación residiría en actuar por un motivo aún más reprobable, como es matar a alguien con quien no se tiene ninguna relación sin más motivo que el lucrarse por el hecho de ejecutarlo 221 .

En este sentido se pronuncia la STS 2809/2008, sobre tentativa de asesinato: "tampoco bastaría que hubiese conocido la existencia de precio

\footnotetext{
${ }^{217}$ Martos Núñez, J. A. (1994). "La circunstancia de precio, recompensa o promesa en el Sistema Penal Español”, en Poder Judicial, n 36, pág. 54.

${ }^{218}$ Martos Núñez, (2017), op. cit., pág. 52.

${ }^{219}$ Roca Agapito, L. (2005). "Inducción mediante precio y cooperación con el sicario en la muerte del marido. La supuesta función unificadora de la jurisprudencia del Tribunal Supremo", en Revista de derecho penal y criminología, no 15, pág. 300.

${ }^{220}$ Ahí considera Roca Agapito que radica el mayor reproche personal del autor. Ibid., pág. 297.

${ }^{221}$ Ibid., pág. 303.
} 
como motor de la conducta de algunos de los demás implicados (...), pues, con todo, él no habría actuado «por»-o «mediante»- «precio, recompensa o promesa»".

Según Martos Núñez ${ }^{222}$ tiene cuatro elementos constitutivos:

- El presupuesto objetivo: el precio, recompensa o promesa.

- Los sujetos activos: el autor moral y el ejecutor material.

- El pactum scaelereris, es decir, el acuerdo entre quien entrega el precio, recompensa o promesa, y quien lo recibe.

- El móvil lucrativo.

Puede ser de las tres formas mencionadas:

- Precio, que se refiere a una cantidad concreta de dinero o a algo que tiene valor económico, como por ejemplo unas joyas ${ }^{223}$.

- Recompensa, remuneración o contraprestación que también tiene valor económico pero es distinto del precio, como puede ser un ascenso laboral en un puesto de trabajo.

- Promesa, que es satisfacer en el futuro una retribución, es decir, que se ofrece una ventaja económica cuyo pago se aplaza al futuro y puede ser en forma de precio o de recompensa.

Algunos autores elaboran otra clasificación, no basada en la naturaleza del pago, sino en el momento en que este se realiza. Según esa distribución, el precio se paga por adelantado, la recompensa es recibida $a$ posteriori y la promesa en el futuro. Sin embargo, la mayoría de la doctrina entiende que es más correcta la primera forma y que en el precio y la

\footnotetext{
${ }^{222}$ Martos Núñez (1994), op. cit., pág. 59.

${ }^{223}$ Roca Agapito, op. cit., pág. 293.
} 
recompensa es irrelevante el momento de su obtención, siempre que el pacto se haya acordado con anterioridad a la ejecución del hecho ${ }^{224}$.

Una de las cuestiones que se plantean relacionadas con esta modalidad, es la de la bilateralidad y su compatibilidad con la inducción, es decir, si la agravante afecta tanto al que entrega el precio o lo promete, como al que ejecuta el delito motivado por esa oferta, o si solo se le aplica al autor, mientras que al inductor se le juzgaría como homicida. Basándose en el art. $65 \mathrm{CP}^{225}$, hay un sector jurisprudencial que "considera que la agravante de precio es predicable tanto respecto al sicario, como respecto al que, mediante el precio entregado o prometido corrompe a tercero y le induce a ejecutar un hecho delictivo. El tratamiento punitivo idéntico del que da y el que recibe el precio está establecido en nuestros Códigos para el cohecho (...).

El art. 65 CP de 1995, constituye por otra parte, una base normativa determinante de que la agravante de precio afecta tanto al que ejecuta el hecho delictivo movido por la merced recibida o prometida, como al que entregó el precio o lo prometió, al establecerse en el mencionado precepto que las agravantes y atenuantes se extienden a todos los partícipes (...). Y por otra parte es indudable que es apreciable un plus de reprochabilidad en

\footnotetext{
224 Ibid., pág. 294.

225 1. Las circunstancias agravantes o atenuantes que consistan en cualquier causa de naturaleza personal agravarán o atenuarán la responsabilidad sólo de aquéllos en quienes concurran.
}

2. Las que consistan en la ejecución material del hecho o en los medios empleados para realizarla, servirán únicamente para agravar o atenuar la responsabilidad de los que hayan tenido conocimiento de ellas en el momento de la acción o de su cooperación para el delito.

3. Cuando en el inductor o en el cooperador necesario no concurran las condiciones, cualidades o relaciones personales que fundamentan la culpabilidad del autor, los jueces o tribunales podrán imponer la pena inferior en grado a la señalada por la ley para la infracción de que se trate.

Este último apartado fue añadido por la LO 15/2003, de 25 de noviembre, en vigor desde el 1 de octubre de 2004. 
la inducción delictiva que se basa y apoya en contraprestaciones económicas entregadas o prometidas al inducido",226.

Por otra parte, existen sentencias que entienden lo contrario, argumentando el principio non bis in idem, ya que si la inducción se basa solo en el ofrecimiento del precio, no se puede valorar dos veces, una como provocadora de la instigación y otra como agravante: "Si para que sea aplicable la agravación de precio es preciso que éste motive el hecho del que lo recibe, es evidente que la agravación funciona como instrumento de la inducción (...) hay inducción porque mediando precio se creó el dolo en el ejecutor (...) no cabe apreciar la agravante de precio si ya ha sido tomada en consideración para conformar conceptualmente la inducción (...) el precio se integra en la inducción por lo que no cabe una doble valoración jurídica, como inductor partícipe, equiparado al autor en su penalidad, y como presupuesto de la agravación específica»,227.

De esa misma opinión es algún sector doctrinal, al afirmar que esta circunstancia solo produce el efecto de agravante al autor material del hecho, si se entiende que es una cuestión de actitud interna y por lo tanto el fundamento de la agravación de la pena se encuentra en una mayor culpabilidad. En ese caso, solo podría aplicarse el tipo agravado a los autores directos, si atendemos "los principios generales que rigen la participación (responsabilidad personal, culpabilidad y accesoriedad limitada), ${ }^{, 228}$.

Ante esta situación contradictoria, se plantea una solución en el FD 6 de la STS 1828/2018, de 24 de mayo: "Aunque será preciso examinar las características del caso, si la única razón de que el inducido acepte la

\footnotetext{
${ }^{226}$ FD 2 de la STS 1663/2003, de 11 de marzo.

${ }^{227}$ FD 2 de la STS 7251/2002, de 31 de octubre, que desestima la aplicación de la agravante por precio.

${ }^{228}$ Roca Agapito, op. cit., pág. 305. 
propuesta del inductor es el precio, la agravante podrá ser cuestionada. Sin embargo, no existirá inconveniente si la inducción encuentra otras bases y el precio es un elemento añadido, no imprescindible, que demuestra una mayor antijuricidad en la conducta".

La doctrina dominante considera que la conducta del que paga se entiende grave porque se supone premeditada y con cobardía, ya que implica valerse de otro para ejecutar el hecho delictivo ${ }^{229}$. Mir Puig ${ }^{230}$ aprecia un doble fundamento en la agravación, por una parte, por el autor, debido a la vileza del móvil, y por otra, imputable tanto al autor como al inductor, que es la mayor dificultad en descubrir el hecho por la ausencia de relación entre la víctima y el asesino, lo que permite al inductor, que sí tiene ese vínculo, presentar una coartada que haga más difícil descubrir a los autores del ilícito penal.

\subsubsection{El ensañamiento.}

Según el Código Penal, regulada como circunstancia agravante del art. $22.5^{\text {a }}$, actúa con ensañamiento quien aumente deliberada e inhumanamente el sufrimiento de la víctima, causando a ésta padecimientos innecesarios para la ejecución del delito. Aunque esta fórmula no coincide exactamente con la del 139, sus elementos son los mismos y, por este motivo, la doctrina y la jurisprudencia hablan indistintamente de los elementos de la circunstancia agravante general del art. 22 y de los elementos del ensañamiento que integra el tipo del asesinato, el de las lesiones o el de otros delitos, de forma que se establece una doctrina común ${ }^{231}$.

\footnotetext{
${ }^{229}$ Martos Núñez (1994), op. cit., pág. 64.

${ }^{230}$ Citado por Roca Agapito, op. cit., pág. 304.

${ }^{231}$ Alonso Álamo (2015). El ensañamiento, op. cit., pág. 3.
} 
Esta característica exige que el sujeto pasivo sea una persona viva y que se encuentre consciente, ya que busca no solo provocar la muerte, sino incrementar el dolor de la víctima, de manera que no sea necesaria para la ejecución del delito. Integra el animus necandi y además con crueldad, lo que justifica la agravación del hecho, ya que además de quitar la vida, se ejecuta el hecho de forma que se atenta contra la dignidad o integridad moral de la víctima.

Sobre el requisito de que el sufrimiento causado no sea necesario, este se interpreta desde una perspectiva objetiva en relación con el resultado delictivo, la muerte ${ }^{232}$. Por otra parte, el elemento subjetivo exige que el acto se ejecute de forma deliberada y es aplicable siempre que el aumento del sufrimiento sea el objetivo prioritario y directo del agresor.

La circunstancia agravante de ensañamiento es explicada por la jurisprudencia del TS, por ejemplo, en la Sentencia 4924/2015, de 13 de noviembre, al indicar, en su FD 3, que el ensañamiento "Es necesario que denote el deseo de causar sufrimientos adicionales a la víctima, deleitándose en la metódica y perversa forma de ejecutar el delito de homicidio, de manera que la víctima experimente dolores o sufrimientos que antecedan a la muerte y que sea un prolegómeno agónico del desenlace final. Se caracteriza por una cierta frialdad en la ejecución ya que se calcula hasta el milímetro la fase previa de aumento injustificado del dolor y sólo movido por el placer personal". Por lo tanto el elemento definitorio es el carácter innecesario de ese aumento del sufrimiento en la víctima y que esto se haga de manera consciente.

Esa misma sentencia dictamina que la moderna jurisprudencia ya no viene exigiendo la premeditación porque basta con que sea deliberado, es

${ }^{232}$ Gómez Rivero, op. cit., pág. 54. 
decir, que el autor sepa lo que está haciendo, e inhumano ${ }^{233}$, entendido como un comportamiento impropio de un ser humano. "No es preciso, por lo tanto, que exista frialdad de ánimo, ni tampoco que la acción vaya dirigida directa y exclusivamente a la causación de mayor dolor"234. La jurisprudencia determina que hay quien controla más y quien controla menos sus sentimientos y que la existencia de la característica del ensañamiento no puede hacerse depender de ese hecho.

También se incluyen los supuestos de vejación y de humillación hacia la víctima, como una especie de "dolor moral" "235, cuando tras estos se produce su muerte.

Requiere dos elementos ${ }^{236}$ :

- Uno objetivo: causar males que aumenten el dolor o el sufrimiento de la víctima, objetivamente innecesarios para alcanzar el resultado típico, bien por torturas que conduzcan al fallecimiento o porque la forma de producir la muerte provoque sufrimientos añadidos.

- Uno subjetivo: que el sujeto activo realice el hecho de manera consciente y deliberada ${ }^{237}$, que sepa que con su actuación incrementa el sufrimiento de la víctima y conoce su carácter de innecesario, así como del exceso deliberado.

${ }^{233}$ La STS 5798/2002, de 9 de septiembre, explica, en su FD 7B) este término, como una "particular disposición del ánimo del autor del hecho: su crueldad o complacencia propia en el sufrimiento de la víctima, o carencia, de modo extremo, de todo sentimiento de humanidad o de respeto que el sujeto pasivo merece en su calidad de persona".

${ }^{234}$ FD 5 de la STS 2535/2017, de 26 de junio.

${ }^{235}$ Muñoz Conde (2015), op.cit., pág. 55.

${ }^{236}$ Martos Núñez (2017), op. cit., pág. 31.

237 Según la jurisprudencia, esto implica que hay un dolo homicida, es decir, que el autor sabe que mata y quiere hacerlo, y un dolo de ensañamiento, que implica conocer (y querer) que lo hace con ese aumento de sufrimiento de la víctima. (FD 7B) de la STS 5798/2002, de 9 de septiembre). 
Otro de los aspectos discutidos es la de las agresiones repetidas, por ejemplo, cuando hay numerosas puñaladas sobre la víctima. Como hemos comentado, lo relevante no es el número en sí, sino si su carácter es necesario, es decir, si la primera es mortal o no. En un principio, si los primeros golpes son mortales y con la víctima en situación de agonía se reiteran, sí se considera que existe ensañamiento, mientras que no lo hay en el caso de que los golpes continúen si es de manera alocada, no racional, y no se puede demostrar si se encontraba viva en ese momento. Según el Supremo, "sólo del número de golpes y de puñaladas no se puede deducir la circunstancia de ensañamiento si no consta el ánimo de aumentar el dolor del ofendido (...) el hecho probable (...) de que el fallecimiento ya se hubiese producido (...) impide apreciar el ensañamiento a causa de la ausencia (...) del dato objetivo del mayor dolor sufrido por la víctima a consecuencia de los reiterados golpes que recibió, 238 .

Es decir, en un homicidio pasional, en el que se provocan varias heridas pero no existe el propósito de aumentar su sufrimiento, no concurre esta circunstancia. "Si el agente cree que no está causando sufrimientos innecesarios a su víctima o si considera que son indispensables para producirle la muerte, no estaríamos ante un caso de ensañamiento, porque falta el elemento subjetivo, ${ }^{, 239}$.

Tampoco existe ensañamiento en sentido jurídico penal si el sufrimiento se aumenta sobre otra persona distinta de la víctima, "pues el ensañamiento no es hacer sufrir sin más sino hacer sufrir a la víctima del delito que venga en consideración" 240 .

\footnotetext{
${ }^{238}$ FD 5 de la STS 755/2000, de 4 de febrero.

${ }^{239}$ Martos Núñez (2017), op. cit., pág. 72.

240 Alonso Álamo (2015). El ensañamiento, op. cit., pág. 5 y pone como ejemplo la intención de hacer sufrir a una madre matando a sus hijos, lo que no constituye ensañamiento.
} 
3.2.4. Para facilitar la comisión de otro delito o para evitar que se descubra.

Esta última característica añadida en la reforma de 2015 ya aparecía en otros códigos de la historia penal española -como hemos visto, en 1822 y 1928- y también en algunos países de nuestro entorno (Alemania, Francia, Italia, Portugal). Se justifica por "la necesidad preventiva de una mayor protección de la vida cuando ésta se encuentra en una situación especialmente peligrosa"241, como que el autor busque, aunque sea a través del asesinato $^{242}$, evitar su responsabilidad por otro delito cometido con anterioridad.

Con esta nueva circunstancia y, respecto su primera modalidad, facilitar la comisión de otro delito, la doctrina ${ }^{243}$ plantea el problema de su autonomía y la compatibilidad con que se facilite una muerte alevosa, ya que, al concurrir ambas, sería de aplicación el tipo cualificado del art. 139.2, lo que podría vulnerar el principio "ne bis in idem, salvo que se interprete de forma restrictiva y se evite incluir en este delito casos que no tienen la gravedad de los supuestos susceptibles de incluirse en las otras circunstancias constitutivas de asesinato".

En lo referente a en qué punto ha de encontrarse el otro delito para apreciarse esta nueva agravante, "Parece correcto afirmar que, en un iter criminis definido por la sucesión de las fases de deliberación, resolución, preparación y ejecución, que culminaría en la consumación, el delito que se pretende facilitar ha de haber superado, al menos, la etapa de resolución y no ha de encontrarse todavía consumado"244. "Facilitar la comisión de otro

\footnotetext{
${ }^{241}$ NK-Neumann, $3^{\text {a }}$ ed., $§ 211$, núm. marg. 97. Citado por Cadena Serrano, op. cit.

${ }^{242}$ Esta nueva circunstancia exige que se cometa un delito anterior, "diferenciado del hecho de dar muerte a otro, de modo que no abarca los actos de mera progresión de la ejecución del delito en unidad de contexto”. Morales Prats, op. cit., pág. 57.

${ }^{243}$ Muñoz Conde (2015), op.cit., pág. 47.

244 Pantaleón Díaz, M. y Sobejano Nieto, D. (2014). "El asesinato para facilitar la comisión de otro delito o para evitar que se descubra: la propuesta de dos nuevas
} 
delito por tanto es algo que se sitúa en el plan del autor, como finalidad específica del mismo. De este modo, ese "otro" delito no es preciso que haya empezado a prepararse, ni mucho menos a ejecutarse" ${ }^{, 245}$.

Para Alonso de Escamilla, se trata "de una facilitación objetiva de acuerdo con el plan de autor". Lo que convierte el homicidio en asesinato es la finalidad con la que actúa el autor del delito "para facilitar la comisión de otro". Así, "esta modalidad de asesinato se consumará cuando se produzca el resultado de muerte, no siendo necesaria la consumación del delito que se pretende favorecer con la muerte" 246 .

Se entiende además, que su aplicación se limita al mismo sujeto activo y no a distintos. La creación del tipo "responde a los motivos personales que han determinado a llevar la acción de matar a otro, esa es la ratio que informa la creación de este precepto", que "contempla la facilitación objetiva futura de la comisión de otro delito",247.

Otros autores, sin embargo sí entienden que se aplique a otros. "Basta con que el autor mate justamente con la intención determinada de facilitar o de evitar el descubrimiento del ya cometido"248, independientemente de si es un delito cometido por él mismo o por un tercero.

El fundamento de la agravación podemos encontrarlo en un mayor contenido del injusto, bien por poner en peligro otros bienes jurídicos, además del de la vida de la víctima, o bien por no tener justificación, ya

modalidades de asesinato en el Código Penal español", en Revista Jurídica de la Universidad Autónoma de Madrid, $\mathrm{n}^{\circ}$ 29, pág. 219.

${ }^{245}$ Morales Prats, op. cit., pág. 56.

${ }^{246}$ Alonso de Escamilla, op. cit., pág. 18.

${ }^{247}$ Morales Prats, op. cit., pág. 56. De la misma opinión son otros autores como Álvarez y Ventura, no así Pantaleón y Sobejano (op. cit.), que interpretan que abarcaría la muerte provocada para facilitar el delito de una tercera persona.

${ }^{248}$ González Cussac (coord.), op cit., pág. 64. 
que no existen circunstancias como la legítima defensa o el estado de necesidad $^{249}$.

En cuanto a la segunda forma, evitar que se descubra otro delito, se justifica por la protección de la Administración de Justicia, ya que este acto va más allá del dolo de ejecución del asesinato. Este otro delito puede ser anterior, simultáneo o posterior a la comisión del asesinato, siempre que la muerte sea provocada para evitar que se descubra el delito que se pretende encubrir. "Lo decisivo es el específico elemento subjetivo intencional del autor, la finalidad de no ser descubierto que preside la ejecución de la muerte y que se añade al dolo homicida"250. La ley, no se referiría así a los motivos del autor, ni a su actitud interna o su desprecio por la vida.

Un sector doctrinal discute la aplicación de esta circunstancia en determinados supuestos:

- Asesinatos subsiguientes a un delito contra la libertad sexual, que actualmente el CP castiga en el art. 140.1.2 , muerte que se considera asesinato con esa motivación, sin necesidad de que concurran otras circunstancias. Para Muñoz Conde, "matar a la víctima de un delito contra la libertad sexual para evitar que denuncie a quien la mata, constituye una doble valoración jurídica de un mismo hecho" 251 .

- Lo mismo ocurriría en casos de malos tratos en los que, para evitar la denuncia, el agresor mata a la víctima.

- Matar para evitar el descubrimiento del delito cometido por otra persona, como un familiar o por una motivación económica, caso

\footnotetext{
${ }^{249}$ Pantaleón Díaz y Sobejano Nieto, op. cit., pág. 219.

${ }^{250}$ Alonso Álamo, M. (2015). “La reforma...”, op. cit., pág. 42.

${ }^{251}$ Muñoz Conde (2015), op. cit., pág. 47.
} 
este último en el que podría entrar en consideración la circunstancia de precio.

Antes de la reforma, estos supuestos se resolvían aplicando el concurso real de delitos, al ser la evitación de que se descubra otro delito lo que caracterizaba el asesinato ${ }^{252}$.

Muñoz Conde sostiene que "si el delito ya es conocido o ha sido descubierto, matar a quien lo ha denunciado o al policía que intenta detener al autor; no haría aplicable esta circunstancia y, por tanto, no sería aplicable cuando el delito que se pretende encubrir se cometió hace ya mucho tiempo y ni siquiera es ya perseguible por haber prescrito" ${ }^{, 253}$.

\subsubsection{El asesinato hiperagravado.}

Otra de las novedades introducidas por la LO 1/2015, de 30 de marzo, ha sido la inclusión del asesinato hiperagravado o hipercualificado ${ }^{254}$, que conlleva la pena de prisión permanente revisable en los casos que se enumeran en el art. $140^{255}$ :

${ }^{252}$ Alonso de Escamilla, op. cit., pág. 18.

${ }^{253}$ Muñoz Conde (2015), op. cit., pág. 24.

${ }^{254}$ Cadena Serrano F. Á. (2015). Delitos de homicidio y asesinato en la reforma operada en el código penal por Ley Orgánica 1/2015. Ponencia de Fidel Ángel Cadena Serrano, Fiscal de Sala del TS, el 8 de octubre de 2015 en Madrid, [en línea] [Disponible en

https://www.fiscal.es/fiscal/PA_WebApp_SGNTJ_NFIS/descarga/Ponencia_CADENA _SERRANO.pdf?idFile=1e3aa192-5aad-41bc-b734-a79ece5d1740].

${ }^{255}$ En el caso de aplicarse esta pena, las circunstancias agravantes o atenuantes no modificarán el marco penal "salvo que por algún motivo expresamente previsto quepa aplicar la pena inferior en grado" (tentativa, complicidad, eximente incompleta, etc.) y según el art. 70.4, la pena inferior en grado a la de prisión permanente revisable es la prisión de veinte a treinta años. Muñoz Conde (2015), op cit., pág. 28. 
1. ${ }^{a}$ Que la víctima sea menor de dieciséis años de edad ${ }^{256}$, o se trate de una persona especialmente vulnerable por razón de su edad, enfermedad o discapacidad.

2. ${ }^{a}$ Que el hecho fuera subsiguiente a un delito contra la libertad sexual que el autor hubiera cometido sobre la víctima. La muerte ha de provocarse una vez que se haya producido el delito contra la libertad sexual, sin que sea necesario que desde que comienza este se tenga la intención de cometer el asesinato ${ }^{257}$.

3. ${ }^{a}$ Que el delito se hubiera cometido por quien perteneciere a un grupo u organización criminal ${ }^{258}$. Aquí se incluyen las bandas terroristas. Esto puede plantear un problema concursal o de vulneración del principio non bis in ídem, puesto que "ya es autónomamente sancionable la pertenencia a tales grupos u organizaciones" 259 .

Hay grupos de víctimas especiales ${ }^{260}$ por sus circunstancias, como la edad, situación de minusvalía; o por el tipo de delito, como violencia sexual, terrorismo o crimen organizado, que se considera que merecen mayor protección y una atención concreta a sus necesidades en particular.

\footnotetext{
${ }^{256}$ Llama la atención el límite de dieciséis años, por la disparidad de criterios del ordenamiento jurídico, por ejemplo que para ser penalmente imputable como adulto el requisito sea la mayoría de edad, según el art. $19 \mathrm{CP}$, y que para exigir responsabilidad según la Ley Orgánica 5/2000, de 12 de enero, de responsabilidad penal de los menores, se establezca en catorce.

${ }^{257}$ Cadena Serrano, op.cit., págs. 92-93.

${ }^{258}$ La diferencia entre organización y grupo la encontramos en el art. 570 bis y ter del CP. El bis castiga con distintas penas en función de los delitos, a quienes promovieren, constituyeren, organizaren, coordinaren o dirigieren una organización criminal, mientras que en el ter se refiere a quienes constituyeren, financiaren o integraren un grupo criminal. La organización presenta una estructura más compleja que el grupo, con un carácter más estable y se sanciona con penas mayores según este artículo.

${ }^{259}$ Sanz Morán (2016), op. cit., pág. 833.

${ }^{260}$ Sanz Hermida, Á. Mª (2009). Víctimas de delitos: derechos, protección y asistencia. Madrid: Iustel, págs. 35 y 36.
} 
Dentro del primer grupo, víctimas menores de dieciséis años o personas especialmente vulnerables, se entiende que son víctimas que necesitan especial protección, donde además de niños, el legislador está pensando en ancianos, enfermos o discapacitados y responde a razones de política criminal para castigar hechos "dignos de mayor reproche social, frente a los cuales la sociedad exige mayor protección juridicopenal y, en su caso, una respuesta contundente del sistema punitivo (...) también, una intensa protección de la víctima frente a su asesino, hasta ahora, privilegiado en cuanto a los factores psicológicos y psiquiátricos que motivaron su crimen, frente al relativo abandono de la víctima a su suerte" ${ }^{, 261}$.

Por otra parte, algunos sectores entienden que "la vulnerabilidad referida a la edad, enfermedad o discapacidad no puede servir para agravar la conducta del autor" si ya incluye la alevosía, por lo que no era necesaria la inclusión de esta circunstancia ${ }^{262}$. Lo mismo plantea Alonso Álamo, por una posible concurrencia de la alevosía con esta circunstancia, al entender que la alevosía debido a su definición, como medios, modos o formas de ejecución que tienden a asegurar el resultado, ya agrava como elemento objetivo-final que hace referencia a la peligrosidad de la acción, por lo que ya quedaría incluida dentro de la alevosía por desvalimiento de la víctima, bien sea "esencial o constitutivo", como en el caso de recién nacidos, o bien "existencial", como ancianos o incapaces de defenderse ${ }^{263}$.

En este sentido se pronuncia el Supremo, en la STS 82/2019, de 16 de enero, "la reforma no ha introducido modificación en la definición de alevosía, donde procurarse y aprovecharse de la situación de indefensión de la víctima, integra su esencia. (...) dada la inescindibilidad descrita del

\footnotetext{
${ }^{261}$ Martos Núñez (2017), op. cit., pág. 91.

${ }^{262}$ Alonso de Escamilla, op. cit., pág. 7.

${ }^{263}$ Alonso Álamo (2015). "La reforma...”, op. cit., págs. 34 y 35. 
ataque sorpresivo con el desvalimiento o vulnerabilidad de la víctima en la causación de la indefensión, al haber sido buscada por el autor para asegurar la ejecución del delito sin riesgo propio, tanto si la indefensión que genera la especial vulnerabilidad de la víctima, autónomamente considerada, resulta subsumible en abuso de superioridad, como en alevosía, una vez apreciada la alevosía que cualifica el asesinato, no puede volver a ponderarse esa vulnerabilidad en evitación de doble ponderación de la situación de indefensión, con quiebra del principio non bis in idem".

En todo caso, cabe su apreciación en los asesinatos calificados así por otro motivo distinto de la alevosía (como por precio, recompensa o promesa; o por ensañamiento), en los que además se cualifique por ser la víctima especialmente vulnerable ${ }^{264}$.

Peñaranda Ramos entiende que hay que interpretar restrictivamente "la circunstancia de alevosía o descartar la aplicación conjunta de tal circunstancia con la de la de minoría de edad o especial desvalimiento para no vulnerar el principio ne bis in ídem"265.

Para que la necesidad de conocimiento o no, por parte del autor del asesinato, de la edad de la víctima sea relevante para aplicar esta pena, según Muñoz Conde, lo más adecuado "es considerar que lo importante es que el autor tenga conocimiento de la situación de vulnerabilidad del menor, independientemente de la edad exacta que tenga, entrando entonces por esta vía su muerte en esta agravación"

\footnotetext{
${ }^{264}$ Muñoz Conde (2015), op. cit., pág. 28. De la misma opinión son otros autores como Suárez, C. y Rodríguez, M. (2015). "Del homicidio y sus formas", en Comentarios a la Reforma del Código Penal de 2015. Valencia. Tirant, pág. 480.

${ }^{265}$ Peñaranda Ramos, E. (2016). “Los delitos de homicidio...”, op. cit., pág. 1277.

${ }^{266}$ Muñoz Conde (2015), op. cit., pág. 28.
} 
Lo determinante son los efectos que produce "en la capacidad de manejarse el sujeto física o mentalmente y no la gravedad de la enfermedad o de la discapacidad en sí mismas",267.

Respecto al segundo supuesto, asesinato subsiguiente a un delito contra la libertad sexual, "cabe entender que esta cualificación se debe a la mayor gravedad que encierra el hecho mismo de matar a una persona a la que previamente ya se le ha vulnerado su libertad sexual. Pero no se entiende muy bien por qué se aplica en relación con este delito y no en relación con otros igualmente graves como detención ilegal, secuestro, robo con violencia, etc."268.

De la misma opinión son Romeo Casabona, Sola Reche y Boldova Pasamar $^{269}$, cuando afirman que "no se entiende por qué no se han incluido, apoyándose en el mismo criterio político-criminal, otros delitos de especial gravedad" como las detenciones ilegales y secuestros más graves.

Muñoz Conde entiende, extremo que compartimos, que es necesario exigir una conexión temporal de inmediatez entre el asesinato y el delito contra la libertad sexual. Si el sujeto activo mata a la víctima días después para que no lo denuncie o por venganza por haberlo hecho, esta cualificación no debe ser aplicada.

En cuanto a los delitos cometidos en el seno de grupos $u$ organizaciones criminales, incluidas las terroristas, la ONU manifiesta que "las víctimas de actos terroristas son víctimas de un delito dirigido contra uno o más Estados o una o varias organizaciones internacionales con el

\footnotetext{
${ }^{267}$ Romeo Casabona, Sola Reche y Boldova Pasamar, op. cit., pág. 15.

${ }^{268}$ Muñoz Conde (2015), op. cit., pág. 28.

${ }^{269}$ Romeo Casabona, Sola Reche y Boldova Pasamar, op. cit., pág. 15. 
propósito de atacar los mayores intereses de un Estado o de la comunidad internacional",270.

Conforme al art. 140, si el autor actúa con finalidad terrorista ${ }^{271}$, la causación de una muerte permite aplicar la prisión permanente revisable aunque no concurran las otras circunstancias del asesinato.

También se impondrá esta pena si se ocasiona la muerte de más de dos personas. En este tipo de supuestos coincidimos con Fermín Morales en la interpretación de este artículo ${ }^{272}$, "en el sentido de que cada una de las muertes ocasionadas, individualmente consideradas, debe ser constitutiva de asesinato, y que las condenas por las mismas deben establecerse en una misma sentencia. Además, esta sería la interpretación del art. 140.2 CP que conectaría con los postulados de la Reforma de 2015, atenta a criterios de derecho penal de autor, que se focalizan hacia supuestos de asesinato

${ }^{270}$ Asamblea General de la ONU, Resolución 64/168, de 18 diciembre 2009, obtenido de: Agudo Fernández, E., Jaén Vallejo, M. y Perrino Pérez, Á. L. (2016). La víctima en la justicia penal. Madrid: Dykinson, pág. 178.

${ }^{271}$ Según el art. 573 CP: Se considerará delito de terrorismo la comisión de cualquier delito grave contra la vida o la integridad física, la libertad, la integridad moral, la libertad e indemnidad sexuales, el patrimonio, los recursos naturales o el medio ambiente, la salud pública, de riesgo catastrófico, incendio, de falsedad documental, contra la Corona, de atentado y tenencia, tráfico y depósito de armas, municiones o explosivos, previstos en el presente Código, y el apoderamiento de aeronaves, buques $u$ otros medios de transporte colectivo o de mercancías, cuando se llevaran a cabo con cualquiera de las siguientes finalidades:

1. ${ }^{a}$ Subvertir el orden constitucional, o suprimir o desestabilizar gravemente el funcionamiento de las instituciones políticas o de las estructuras económicas o sociales del Estado, u obligar a los poderes públicos a realizar un acto o a abstenerse de hacerlo.

2. ${ }^{a}$ Alterar gravemente la paz pública.

3. ${ }^{a}$ Desestabilizar gravemente el funcionamiento de una organización internacional.

4. ${ }^{a}$ Provocar un estado de terror en la población o en una parte de ella.

También los delitos informáticos que se cometan con los mismos objetivos descritos y el resto de delitos regulados en el Cap. VII ("De las organizaciones y grupos terroristas y de los delitos de terrorismo"), del Tít. XXII ("Delitos contra el orden público"), que comprenden los arts. 571 a 580 del CP.

${ }^{272}$ Morales Prats, op.cit., pág. 63. 
múltiple o protagonizados por un "asesino en serie" que es condenado en una misma sentencia por los mismos".

Otras interpretaciones, sin embargo, entienden que "bastaría que solo una de las muertes fuera asesinato, aunque consideró que se debía descartar por lo excepcional de su pena y por el especial agravamiento del régimen de cumplimiento que establecía para estos supuestos"273. Y no incluiría los supuestos de multi-reincidencia en los que el condenado lo haya sido anteriormente en sentencias distintas. Por el contrario, otros autores, como Muñoz Conde, sí consideran que se aplicaría en los casos de reincidentes y que bastaría para ser de aplicación, que el condenado lo haya sido previamente por la muerte de más de dos personas, aunque sea en sentencias diferentes ${ }^{274}$.

"La condena por varias muertes a las que se refiere la agravación es la de la propia sentencia, no una pronunciada en sentencias anteriores (reincidencia) $^{\text {,275. }}$.

También se castiga con prisión permanente revisable el asesinato cuando el sujeto pasivo sea el Rey, la Reina, el Príncipe o la Princesa de Asturias $^{276}$ o un Jefe de Estado extranjero $u$ otra persona internacionalmente protegida por un Tratado, que se halle en España ${ }^{277}$. Asimismo es aplicable en delitos de genocidio, entendidos como tales, destruir total o parcialmente un grupo nacional, étnico, racial, religioso o determinado por discapacidad de sus integrantes, que incluye tanto matar

\footnotetext{
${ }^{273}$ Alonso de Escamilla, op. cit., pág. 19.

${ }^{274}$ Muñoz Conde (2015), op. cit., pág. 30.

${ }^{275}$ Romeo Casabona, Sola Reche y Boldova Pasamar, op. cit., pág. 34.

${ }^{276}$ Art. 485.1 CP, dentro del Libro II "Delitos y sus penas", Título XXI "Delitos contra la Constitución", Capítulo II "Delitos contra la Corona".

${ }^{277}$ Art. 605.1 CP, Título XXIV "Delitos contra la Comunidad Internacional”, Capítulo I "Delitos contra el derecho de gentes".
} 
como agredir a alguno de sus miembros o provocar algunas lesiones ${ }^{278} ; \mathrm{y}$ los de lesa humanidad, considerados aquellos en los que se realiza un ataque generalizado o sistemático contra la población civil o una parte de ella ${ }^{279}$.

Esta pena es objeto de discusión doctrinal, ya que un sector entiende que es inconstitucional al ser una pena de duración indeterminada. Del Carpio Delgado distingue entre prisión perpetua sin posibilidad de libertad condicional, en la que el autor del delito pasa el resto de su vida en prisión sin posibilidad de libertad anticipada, caso de Estados Unidos, por ejemplo; y prisión perpetua con posibilidad de libertad anticipada o libertad condicional, que es una pena indeterminada en cuanto a su naturaleza, pero con posibilidad de revisión para que, cumplido el periodo de tiempo que se establezca privado de libertad, el condenado pueda optar a la libertad condicional $^{280}$. El problema que puede plantear es el de la indeterminación de su concreta duración. "Es contraria a la dignidad de la persona si no se coordina, transcurrido un determinado periodo de cumplimiento, con la posibilidad de la libertad condicional o con la de gracia"281.

Por otra parte, el Preámbulo de la LO 1/2015, de 30 de marzo, mediante la que se llevó a cabo la reforma del Código Penal, la justifica al reducir su imposición a los supuestos de excepcional gravedad ya mencionados y en la que el Estado no se desentiende del penado, sino que compatibiliza la grave respuesta penal con la finalidad de reeducación a la que debe ser orientada la ejecución de las penas de prisión.

\footnotetext{
${ }^{278}$ Art. 607.1 CP, Capítulo II "Delitos de genocidio".

${ }^{279}$ Art. 607 bis.1 y 2, Capítulo II bis "Delitos de lesa humanidad".

${ }^{280}$ Carpio (del) Delgado, J. (2019). La prisión perpetua en el derecho internacional: un estudio sobre la teoría y su práctica por los Tribunales Penales Internacionales "Ad Hoc”. Valencia: Tirant lo Blanch, págs. 98 y 99.

${ }^{281}$ Sanz Morán (2016), op. cit., pág. 825.
} 
A falta de que el Tribunal Constitucional se pronuncie sobre su constitucionalidad o no, el mismo Preámbulo alega también que es una figura extendida en el derecho comparado y avalada por el Tribunal Europeo de Derechos Humanos, por ejemplo en el caso Kafkaris contra Chipre $\left(n^{\circ} 21906 / 04\right)^{282}$, de 12 de febrero de $2008^{283}$, al que acudió un condenado a la pena de cadena perpetua por la comisión de tres asesinatos.

Para cumplir la exigencia de que esta pena no se considere un trato inhumano ni degradante ${ }^{284}$, es fundamental la denominación de revisable. Requiere que exista esa posibilidad de revisión para que se pueda cumplir con su constitucionalidad y con la finalidad resocializadora de la pena ${ }^{285}$, orientada a una prevención especial y, de esta forma, se respete el art. 3 de

282 Preámbulo de la LO 1/2015, de 30 de marzo. BOE [Disponible en https://www.boe.es/buscar/act.php?id=BOE-A-2015-3439].

${ }^{283}$ La Sentencia del Tribunal Europeo de Derechos Humanos dictamina que en los ordenamientos de Francia y de Italia se reconoce el derecho a que se pueda considerar la libertad de un condenado a prisión perpetua, así como en Alemania, donde la reclusión perpetua tampoco supone que no se les pueda conceder una segunda oportunidad con un procedimiento de revisión para su rehabilitación. El Tribunal considera que en este caso Chipre no ha condenado a cadena perpetua sin posibilidad de libertad, ya que lo que el condenado tendría que demostrar para que se vulnerase el art. 3 de la Convención, sería necesario que hubiera una imposibilidad legal o absolutamente ninguna previsión de adelantar su libertad en la práctica, lo que no concurre en este asunto. Sentencia obtenida de https://hudoc.echr.coe.int/eng

${ }^{284}$ Miguel Ángel Cano Paños expone que la diferencia entre la tortura y los tratos inhumanos y degradantes se establece en distintos textos internacionales sobre la materia, de forma que todo acto de tortura supone un trato inhumano y degradante pero puede haber actos inhumanos que no lleguen a la categoría de tortura, término que se reserva para supuestos más concretos. Ambos implican sufrimiento de la víctima pero difieren en la gravedad del sufrimiento y en la intención del autor. Cano Paños, M.Á. (2017). En los límites de la exclusión de la responsabilidad penal. Barcelona: Bosch, págs. 95-109.

${ }^{285}$ Así lo establece nuestro ordenamiento en el art. 25.2 CE: Las penas privativas de libertad y las medidas de seguridad estarán orientadas hacia la reeducación y reinserción social y no podrán consistir en trabajos forzados; y también el art. 1 de la Ley Orgánica 1/1979, de 26 de septiembre, General Penitenciaria (LOGP): Las instituciones penitenciarias reguladas en la presente Ley tienen como fin primordial la reeducación y la reinserción social de los sentenciados a penas y medidas penales privativas de libertad, así como la retención y custodia de detenidos, presos y penados. 
la Convención Europea de Derechos Humanos ${ }^{286}$, a pesar de que no ofrece una definición de esos conceptos ni su delimitación para distinguirlos de otros malos tratos prohibidos ${ }^{287}$, algo que sí se ha hecho más tarde en la Declaración sobre la Protección de todas las personas contra la tortura y otros tratos o penas crueles, inhumanas o degradantes, de la Asamblea de las Naciones Unidas, el 9 de diciembre de $1975^{288}$.

${ }^{286}$ Nadie podrá ser sometido a tortura ni a penas o tratos inhumanos o degradantes. (1950), [en línea] [Disponible en http://www.echr.coe.int/documents/convention_spa.pdf].

${ }^{287}$ Gudín Rodríguez-Magariños, F. (2009). El estado de derecho frente a la tortura. Valencia: Tirant, pág. 179.

288 “Se entenderá por tortura todo acto por el cual un funcionario público, u otra persona a instigación suya, inflija intencionadamente a una persona penas o sufrimientos graves, ya sean físicos o mentales, con el fin de obtener de ella o de un tercero información o una confesión, de castigarla por un acto que haya cometido, o de intimidar a esa persona o a otras. No se considerarán torturas las penas o sufrimientos que sean consecuencia únicamente de la privación legítima de libertad (...) en la medida que estén en consonancia con las Reglas mínimas para el tratamiento de los reclusos”. 


\section{LA INSTITUCIÓN DEL JURADO.}

\subsection{Clasificación de los distintos tipos de jurado y sus diferencias entre el sistema español y el de otros países.}

Existen tres clases de jurado que presentan importantes diferencias entre ellos. Una mención aparte requieren los Países Bajos, único Estado de la Unión Europea que no tiene jurado ${ }^{289}$.

Los dos modelos más extendidos son el anglosajón o puro y el escabinado y existe un tercer sistema mixto que presenta características de los dos, ya que adopta del puro la emisión del veredicto y del tribunal de escabinos el que se reúnan con los profesionales para votar y decidir la pena a imponer. Está vigente en algunos países europeos como Austria o Noruega ${ }^{290}$.

\subsubsection{Modelo anglosajón o puro.}

Este es el tipo que rige en España aunque hay algunas diferencias respecto a otros países ${ }^{291}$. Se caracteriza esencialmente por la composición de

\footnotetext{
${ }^{289}$ Las causas penales las enjuician los jueces de lo penal, quienes resuelven sobre la calificación jurídica de los delitos y puede ser un tribunal compuesto por tres miembros, si el delito es grave, o un solo juez si es leve. También existen los jueces cantonales, que se ocupan de los juicios de faltas. Obtenido de European justice: [en línea]

[Disponible en

https://e-justice.europa.eu/content_judicial_systems_in_member_states-16-nles.do?member=1].

${ }^{290}$ González Pillado, E. y Villagómez Cebrián, M. (2005). El Tribunal del Jurado. Madrid: Boletín Oficial del Estado.

${ }^{291}$ Existe gran debate en la doctrina sobre si el modelo puro es el más adecuado y, aunque el legislador no especificó expresamente qué sistema seguir, se optó por este. A pesar de los numerosos detractores, Joaquín Sánchez-Covisa Villa hace un análisis del jurado tras diez años de vigencia de la ley y concluye que "Los ciudadanos han desarrollado con manifiesta responsabilidad, capacidad y rigor la función encomendada. Ninguno de los temores y prejuicios sostenidos por un sector importante de la doctrina
} 
ciudadanos legos elegidos por sorteo y la separación entre el hecho, función exclusiva de los jurados, y el Derecho, competencia de los profesionales. Los legos declaran los hechos probados o no y emiten veredicto de culpabilidad o inculpabilidad y, siguiendo ese veredicto, el juez dicta sentencia e impone la pena correspondiente o determina la absolución. También se pronuncian sobre las circunstancias modificativas de la responsabilidad, esta inclusión se justificó para evitar que, debido a la separación de los hechos y la aplicación del Derecho, se emitieran veredictos absolutorios injustificados por temor a que en caso de condena el tribunal fuera muy riguroso con la imposición de la pena.

\subsubsection{Inglaterra y Gales.}

Se considera que el origen del jurado es inglés y data de 1066, en el momento de la invasión de los normandos, y se culminará un siglo más tarde, en 1166, con el Assize de Clarendon ${ }^{292}$, dictado por Enrique II, y por el que se sometía a los acusados a las ordalías o juicios de Dios ${ }^{293}$. Alcanzó su plenitud con la Carta Magna, el 12 de junio de 1215, momento en el que se suele establecer el nacimiento del jurado moderno ${ }^{294}$. Su fundamento

científica y de nuestro entorno profesional tiene el más mínimo fundamento. Al contrario, son muchos los datos que acreditan haber superado de manera sobresaliente los grados de capacitación, inteligencia y comprensión exigidos por la difícil función encomendada". Sánchez-Covisa Villa, J., en Martín Pallín, J. A., et al. (2006). La Ley del Jurado en su X Aniversario. Navarra: Thomson Aranzadi, pág. 70.

292 The Avalon Project: Documents in Law, History and Diplomacy [en línea] [Disponible en: http://avalon.law.yale.edu/medieval/assizecl.asp].

${ }^{293}$ El profesor Van Caenegem habla de la influencia del derecho canónico (Canon Law) en el Assize de Clarendon y, por lo tanto, en la historia inicial del gran jurado. Helmholz, R. H. (1983). "The Early History of the Grand Jury and the Canon Law", en The University of Chicago Law Review, vol. 50, n 2, pág. 626.

${ }^{294}$ Novo Pérez, M., Arce Fernández, R. y Seijo Martínez, D. (2002). "El tribunal del Jurado en Estados Unidos, Francia y España: tres modelos de participación en la administración de Justicia. Implicaciones para la educación del ciudadano", en Publicaciones, $\mathrm{n}^{\mathrm{o}}$ 32, pág. 337. 
político es el de la democracia participativa aplicada a la administración de justicia, lo que otorga cierto grado de confianza en el sistema penal, tanto para los ciudadanos como para la sociedad, ya que el acusado es juzgado por iguales que están libres de los prejuicios que puedan tener los jueces derivados de su ejercicio profesional, aunque ese mismo motivo sea precisamente el que se argumenta en contra de la institución, el desconocimiento que los ciudadanos en general poseen del mundo jurídico.

En estos países tiene lugar en el Tribunal de la Corona (Crown Court), donde se siguen las causas por los delitos más graves. En la actualidad se regula en la Juries Act (JA), de $1974^{295}$. El jurado se ocupa de los delitos más graves (indictable offences) ${ }^{296}$, como homicidio (y sus modalidades); detenciones ilegales; secuestros; lesiones graves; violación; torturas; robo; chantaje; etc., y de los de gravedad intermedia (either-way offences), por ejemplo, lesiones leves; amenazas; hurtos; estafas; conducción temeraria; tenencia ilícita de armas, etc. ${ }^{297}$.

Para los asuntos penales el tribunal se compone de doce miembros y para los civiles de nueve. Reciben, igual que en nuestro país, una cuantía económica por ejercer de jurado, así como por desplazamiento ${ }^{298}$. Hasta 1933 se dividía en el Jurado de Acusación o Presentación (Grand Jury) ${ }^{299}$, compuesto por unas treinta personas y encargado de decidir si el acusado

\footnotetext{
295 [En línea] [Disponible en:

https://www.legislation.gov.uk/ukpga/1974/23/pdfs/ukpga_19740023_en.pdf].

${ }^{296}$ Se sigue el procedimiento con escrito de acusación formal (trial on indictment), mientras que los delitos leves (offences) se juzgan en los Magistrates' Courts según el procedimiento abreviado o sumario (summary trial). González Jiménez, M. (2006). La institución del jurado: la experiencia española. Madrid: La Ley, pág. 52.

${ }^{297}$ García Moreno, J. M. (2004). "El juicio penal con jurado en Inglaterra y Gales (I)", en Jueces para la democracia, $\mathrm{n}^{\circ}$ 50, págs. 87-100.

298 [En línea] [Disponible en: www.justice.gov.uk/downloads/offenders/psipso/psi2010/psi_2010_19_special_leave_policy.doc].

${ }^{299}$ Tiene su antecedente en las doce personas que formaben el Assize of Clarendom. Pérez Cebadera, M ${ }^{\mathrm{a}}$ Á. (2017). Las instrucciones al jurado. Valencia: Tirant (2 $\mathrm{a}$ ed.), pág. 36.
} 
debía ser juzgado, y el Jurado de Decisión (Petty Jury) ${ }^{300}$, con entre siete y quince miembros, quienes ya deliberaban sobre su culpabilidad o inculpabilidad. Esta división fue adoptada en nuestro ordenamiento y así se juzgaba cuando el jurado estaba regulado en la Ley de imprenta, de 1820. Tras quedar abolido ese Gran Jurado inglés ${ }^{301}$, el tribunal pasó a tener veintitrés miembros presididos por un Magistrado Presidente (Sheriff).

Se realiza el sorteo de entre las personas del censo electoral que se encuentren entre los dieciocho y los setenta años de edad, que hayan residido en el Reino Unido al menos cinco años desde que tenían trece. Las causas de exclusión son parecidas a las de España ${ }^{302}$.

La defensa siempre ha tenido derecho a recusar sin causa (peremptory challenge). El número de candidatos se ha ido reduciendo a lo largo de los años hasta que, con la Criminal Justice Act de 1988, se suprimió este derecho a recusar sin causa. La acusación nunca ha tenido ese derecho pero sí el llamado stand a juror by, que en la práctica tiene los mismos efectos: "cuando quiere rechazar a uno o varios de los candidatos a jurados, no tiene más que emitir la voz de stand-by antes de que procedan a prestar juramento, ante lo cual el interpelado tiene que esperar sentado, procediendo a jurar los restantes candidatos. En cuanto hayan jurado 12 personas, el Tribunal queda compuesto sin necesidad de que la acusación exprese los fundamentos de su impugnación" ${ }^{\text {303 }}$, derecho que también tiene

\footnotetext{
${ }^{300}$ Es en el siglo XIV cuando se separan las funciones entre el jurado de acusación y el de decisión, del que no podía formar parte nadie que hubiera estado en el de acusación. Ibid., pág. 37.

${ }^{301}$ Sin embargo este tribunal sí continúa existiendo en el sistema de Estados Unidos.

302 Condenados, profesionales del mundo jurídico, policías, además de clérigos y enfermos mentales, entre otros. Y pueden excusarse, entre diversas causas, los que tengan entre sesenta y cinco y setenta años, los militares, profesionales de la sanidad o quienes hayan ejercido de jurado en los dos años anteriores. Si alguien forma parte de un jurado sabiendo que en él concurre alguna de las causas de exclusión, puede ser multado con entre 1000 a 5000 libras (unos 1130 a $5650 €$ ).

${ }^{303}$ González Jiménez, op. cit., pág. 59.
} 
el juez, ante la presencia de un candidato manifiestamente carente de los requisitos culturales mínimos que le permitan comprender y valorar una posible prueba documental.

En las causas penales deciden sobre los hechos y el veredicto y en las civiles, además sobre los daños. Como se explicará más adelante en la parte histórica, el Juez hace el llamado summing up, un resumen de los hechos, fórmula que en España se mantuvo hasta 1931. En él se expresa lo siguiente:

- El juez explica que deben determinar los hechos alegados en la vista oral y los probados.

- Les informará sobre las reglas de carga y valoración de la prueba.

- Los elementos configuradores del delito, detallando los puntos que la acusación ha de probar para demostrar la culpabilidad del acusado.

- Que deben considerar cada caso de forma separada si hay más de un acusado.

- Recordarles las pruebas practicadas ${ }^{304}$.

- El deber de elegir un presidente que ejercerá como portavoz del tribunal y anunciará el veredicto al que lleguen.

En principio se exige un veredicto por unanimidad, pero, desde la Criminal Justice Act de 1967, si el caso es muy complicado y después de

\footnotetext{
${ }^{304}$ En este punto hay una diferencia con el derecho español, ya que la LOTJ prohíbe expresamente que durante las instrucciones el Magistrado-Presidente formule una opinión sobre el resultado de las pruebas, mientras que en el ordenamiento inglés no existe dicha prohibición, aunque tampoco es obligatorio que lo manifiesten. Ibid., pág. 70.
} 
un tiempo no se ha logrado, se permite la mayoría por once a uno o diez a $\operatorname{dos}^{305}$. Si el jurado no es capaz de llegar a un veredicto, se disuelve ${ }^{306}$.

Como regla general, el juez se encuentra vinculado al veredicto, como en nuestro ordenamiento, aunque no esté de acuerdo con él. Sin embargo, existen unas excepciones a esta obligación:

- Si el jurado condena por un delito que no esté incluido en el escrito inicial.

- Que el veredicto sea ambiguo acerca de alguno de los cargos, caso en el que podrá formular preguntas al jurado y darles nuevas instrucciones.

- Cuando lleguen a un veredicto inconsistente con otro emitido por el jurado en el mismo caso, por ejemplo, que haya más de un acusado.

Hay otra particularidad que no tiene cabida en España, debido al número de jurados. La Ley permite que, en caso de fallecimiento o enfermedad u otra causa por la que sean apartados los miembros del jurado (causa necesaria considerada por el Juez), se puede continuar con el juicio, siempre que el número no baje de nueve.

\subsubsection{Estados Unidos.}

La Constitución, de 1787, contempla que el jurado juzgue todos los delitos, como garantía de las libertades, ya que lo regula como un derecho tanto del

\footnotetext{
${ }^{305} \mathrm{Si}$ el jurado se ha reducido a menos de doce miembros, se permite diez a uno o nueve a uno. Si se reduce a nueve miembros, se exige unanimidad. Estas mayorías se aplican a todos los veredictos, sean de culpabilidad o de inculpabilidad. Ibid., pág. 77.

${ }^{306}$ El acusado puede ser enjuiciado por otro jurado, en principio, en un número ilimitado de veces, pero en la práctica, si tras la disolución de dos jurados, la acusación no ofrece pruebas en lo que sería un tercer juicio, el juez emite pronunciamiento de inocencia. Ibid., pág. 79.
} 
acusado como de los ciudadanos a la hora de ser elegidos ${ }^{307}$. La norma hace referencia también a un Gran Jurado, cuando el delito está castigado con penal capital o infamante.

El Artículo $3^{308}$ de la norma fundamental americana, relativo al poder judicial, dispone en su segunda sección, punto $3^{309}$, que Todos los delitos serán juzgados por medio de un jurado excepto en los casos de acusación por responsabilidades oficiales; y el juicio de que se habla tendrá lugar en el Estado en que el delito se haya cometido; pero cuando no se haya cometido dentro de los límites de ningún Estado, el juicio se celebrará en el lugar o lugares que el Congreso haya dispuesto por medio de una ley ${ }^{310}$.

También tres de las veintisiete Enmiendas ${ }^{311}$ de la Constitución hacen referencia al jurado. La Quinta Enmienda ${ }^{312}$, que trata sobre el derecho al debido proceso y a no autoincriminarse, regula lo siguiente: Nadie estará obligado a responder de un delito castigado con la pena

307 Así lo establece el principio 2 de The Principles for Juries and Jury Trials (Principios para jurados y juicios con jurados) (2005) de la American Bar Asociation $(A B A)$ (literalmente, Asociación Americana de Abogados, un equivalente a nuestros Colegios de Abogados pero a nivel nacional, fundada el 21 de agosto de 1878). Este proyecto contiene 19 principios que rigen el sistema del jurado.

${ }^{308}$ La Constitución de los Estados Unidos, de 1787, está formada por siete artículos y veintisiete enmiendas. Dichos artículos, a pesar de su nombre, son un equivalente de los títulos en nuestra Constitución. Es decir, que cada artículo de la constitución estadounidense regula una materia y se divide en secciones, que, a su vez, contienen varios puntos numerados.

${ }^{309}$ Constitución de los Estados Unidos. [En línea] [Disponible en:

https://www.constitutionfacts.com/content/constitution/files/usconstitution_spanish.pdf]

${ }^{310}$ Las normas federales que regulan el procedimiento penal (Federal Rules of Criminal Procedure, 1946) establecen que los delitos competencia del jurado son juzgados por él, salvo si el acusado hace una renuncia por escrito, con el consentimiento del Fiscal y del Tribunal. Pérez Cebadera, op. cit., pág. 22.

${ }^{311}$ Las Enmiendas, para realizar alguna modificación constitucional, se proponen y aprueban según el procedimiento que se exige en el Artículo 5 de la propia Constitución.

${ }^{312}$ Dentro de las veintisiete Enmiendas, estas menciones al jurado forman parte de la llamada Carta de Derechos (Bill of Rights), que se refiere a las diez primeras, aprobadas el 15 de diciembre de 1971. 
capital o con otra infamante si un gran jurado no lo denuncia o acusa, a excepción de los casos que se presenten en las fuerzas de mar o tierra o en la milicia nacional cuando se encuentre en servicio efectivo en tiempo de guerra o peligro público.

La Sexta Enmienda, sobre los derechos del acusado, expone que En toda causa criminal, el acusado gozará del derecho de ser juzgado rápidamente y en público por un jurado imparcial del distrito y Estado en que el delito se haya cometido, Distrito que deberá haber sido determinado previamente por la ley.

Y no solamente tienen competencia sobre todos los delitos ${ }^{313}$ sino que también pueden enjuiciar asuntos civiles. La Séptima Enmienda regula estos casos: El derecho a que se ventilen ante un jurado los juicios de derecho consuetudinario en que el valor que se discuta exceda de veinte dólares, será garantizado, y ningún hecho de que haya conocido un jurado será objeto de nuevo examen en tribunal alguno de los Estados Unidos, como no sea con arreglo a las normas del derecho consuetudinario.

El sistema de selección de los jurados ha ido evolucionando y en la actualidad se sigue el regulado en la Jury Selection and Service Act, de $1968^{314}$. Antiguamente eran elegidos por líderes políticos o sociales (los key men), que nombraban a las personas más justas de su comunidad. A partir de esta ley, se reformó para que existiera mayor representación de todos los grupos sociales y desde entonces se hace también mediante el censo electoral. La selección del jurado en Estados Unidos es pública,

\footnotetext{
${ }^{313}$ Posteriormente, la sentencia del caso Duncan vs. Louisiana, limitó ligeramente este derecho y lo estableció para los delitos que conlleven una pena de más de seis meses de prisión (felony) y no para delitos menores (petty offenses), castigados con menos de seis meses de prisión y multa de hasta 500 dólares. Pérez Cebadera, op. cit., pág. 23.

314 [En línea] [Disponible en: https://www.law.cornell.edu/uscode/text/28/partV/chapter-121]. 
mientras que en España, solamente es para el acusado y los abogados de ambas partes.

Para ser jurado se requiere ${ }^{315}$ tener al menos dieciocho años, ser ciudadano de Estados Unidos, residencia en la jurisdicción correspondiente, ser capaces de comunicarse en inglés y no haber sido condenado por algún delito grave (o estén convictos o en libertad condicional).

Una variante con respecto a los otros países es que existen las exenciones automáticas, para profesiones como médicos, policías, religiosos o militares. Sirve como causa de exclusión, tanto la económica, ya que la remuneración es inferior ${ }^{316}$, como que la duración del juicio cause un perjuicio. También se excluye a los menores de dieciocho, quienes no llevan viviendo en el distrito al menos un año, los analfabetos, los que no dominan el inglés, convictos o procesados y quienes padezcan una enfermedad física o mental que los incapacite para el ejercicio de jurado.

Después se lleva a cabo el proceso de recusaciones, que es más largo que en los casos de España y de Inglaterra ${ }^{317}$, puesto que las recusaciones con causa, las que atentan contra la imparcialidad según los casos previstos en la ley, son ilimitadas. También hay recusaciones sin causa pero estas sí tienen un número limitado, distinto en función del Estado en que se celebre.

\footnotetext{
${ }^{315}$ Principio 2 de los principios de la ABA. Página de la American Bar Association [En línea] [Disponible en:

https://www.americanbar.org/content/dam/aba/administrative/american_jury/principles. authcheckdam.pdf].

${ }^{316}$ Según el $§ 1861$ de la Jury Selection and Service Act es de 40 dólares al día (33'54 $€)$.

${ }^{317}$ En la mayoría de los Estados, la defensa y el Fiscal pueden conseguir la lista de los candidatos antes de comenzar el proceso de selección, por lo que pueden investigarlos para tener motivos fundamentados de recusación. González Jiménez, op. cit., pág. 93.
} 
Tradicionalmente han sido doce jurados que dictaban veredicto por unanimidad pero en realidad la Constitución no exige unanimidad ${ }^{318}$, por lo que en algunas jurisdicciones se permiten ciertos veredictos por mayoría y así lo admite la jurisprudencia ${ }^{319}$. Por ejemplo ${ }^{320}$ en Oregón y Luisiana se puede dar una mayoría de diez a dos, en casos de delitos más graves. Y en Oklahoma, de nueve a tres para delitos menores. Otras jurisdicciones también quieren adoptar este sistema, justificándolo porque consideran que en algunos juicios fracasa el jurado debido a que uno o dos miembros mantienen de manera irracional un punto de vista distinto al de la mayoría $^{321}$. En todo caso, si el jurado está integrado por seis miembros siempre se exige unanimidad. Los veredictos de inculpabilidad son irrecurribles, igual que en Inglaterra, lo que no ocurre en nuestro país.

\footnotetext{
${ }^{318}$ El principio 4 de los Principios de la $A B A$ establece que en los procesos civiles se prefiere la unanimidad siempre que sea posible, aunque se puede admitir una mayoría de cinco sextos, en caso de que los jurados hayan estado deliberando durante un periodo de tiempo razonable. En las causas penales debe ser por unanimidad aunque deja abierta la posibilidad a que el tribunal acepte una mayoría, con la condición inexcusable de que el acusado haya sido informado de su derecho a un veredicto por unanimidad y renuncie a él expresamente.

319 En la sentencia Apodaca vs Oregon, de 1972, el Tribunal Supremo concluye lo siguiente: Although, on the basis of history and precedent, the Sixth Amendment mandates unanimity in a federal jury trial, the Due Process Clause of the Fourteenth Amendment, while requiring States to provide jury trials for serious crimes, does not incorporate (...) all the elements of a jury trial within the meaning of the Sixth Amendment, and does not require jury unanimity. Oregon's "ten of twelve" rule is not violative of due process. (Aunque basándose en la historia y los precedentes, la Sexta Enmienda exige unanimidad en un juicio con jurado, el derecho al debido proceso de la Decimocuarta Enmienda, aunque requiere que los estados proporcionen juicios con jurado para delitos graves, no lo incorpora (...) todos los elementos de un juicio con jurado según el significado de la Sexta Enmienda y no requiere unanimidad del jurado. La regla del "diez de doce" de Oregón no viola el debido proceso). [En línea] [Disponible en: https://supreme.justia.com/cases/federal/us/406/404/case.html].

${ }^{320}$ Dillehay, R.C., Barry-Gabier, P.J. y Dahir, V. (2000). "La evolución del jurado en los casos criminales. Una comparación psicosocial del jurado americano y español”, en Psicología política, $\mathrm{n}^{\circ} 20$, pág. 108.

${ }^{321}$ Neal Elis dice que algunos estudios han demostrado que cuando se cumple la regla de la unanimidad, los jurados son más minuciosos en sus deliberaciones y la consideración de las cuestiones legales es más completa. Elis, N. (2006). "Saving the Jury trial" GPSolo, vol. 23, nº 2, pág. 29.
} 
El jurado estadounidense ha evolucionado también respecto al número de miembros y ahora se admite que puedan ser menos de doce ${ }^{322}$, sin que ninguno de estos cambios afecte a la constitucionalidad al considerar el Tribunal Supremo de Estados Unidos, que no vulnera el derecho a ser juzgado por un jurado imparcial, que recoge la Sexta Enmienda ${ }^{323}$.

Aunque el jurado no interviene en la sentencia, sí se permite que en los Estados en los que rige la pena de muerte, si el delito objeto del veredicto conlleva esa pena, se suele requerir al jurado para que decida entre esta o la cadena perpetua ${ }^{324}$. En estos supuestos, el juicio se dividiría en más fases, ya que, tras la práctica de la prueba y la emisión del veredicto

\footnotetext{
${ }^{322}$ A raíz del caso Williams vs Florida, en el que un acusado reclamó un jurado de doce miembros y no de seis, como permitía la Ley de Florida en todos los casos excepto en los de pena de muerte, motivo por el que él alegaba que se vulneraba su derecho a ser juzgado por un jurado, garantizado por la Sexta Enmienda. La resolución estableció: The question in this case, then, is whether the constitutional guarantee of a trial by "jury" necessarily requires trial by exactly 12 persons, rather than some lesser number -in this case, six-. We hold that the 12-man panel is not a necessary ingredient of "trial by jury", and that respondent's refusal to impanel more than the six members provided for by Florida law did not violate petitioner's Sixth Amendment. (La pregunta en este caso es si la garantía constitucional de un juicio por "jurado" requiere de manera necesaria ser juzgado por exactamente 12 personas, en lugar de un número menor -en este caso seis-. Sostenemos que 12 hombres no es un ingrediente necesario del "juicio por jurado" y que el rechazo a la petición de tener más de los seis miembros que permite la Ley de Florida no viola los derechos de la Sexta Enmienda). [En línea] [Disponible en: https://www.law.cornell.edu/supremecourt/text/399/78].

${ }^{323}$ El principio 3 de los Principios de la $A B A$ regula que en los procesos civiles serán doce $\mathrm{y}$, en todo caso, nunca menos de seis. $\mathrm{Y}$ en los penales establece, como regla general, al menos seis personas si la condena es de hasta seis meses de prisión y doce si es de más de seis meses. Existe la misma excepción que se dispone respecto a la unanimidad, es decir, que las partes puedan acordar un número entre seis y doce jurados, con la aprobación del tribunal, y siempre que el acusado haya sido informado de su derecho a ser juzgado por doce jurados y renuncie de manera expresa a él.

${ }^{324}$ Según Alschuler y Deiss, la autoridad de los jurados para resolver asuntos legales ha sido confirmada por constituciones, leyes y decisiones judiciales. Alschuler, Albert W. y Deiss, Andrew G. (1994). "A Brief History of the Criminal Jury in the United States", en The University of Chicago Law Review, vol. 61, nº 3, pág. 903.
} 
de culpabilidad, se estudia si existen circunstancias agravantes que puedan conllevar la imposición de la pena capital.

Por tanto una de las diferencias más importantes respecto a la legislación española es que aquí sí se fija una mayoría y un número de jurados concretos, a través de una Ley que se aplica en todo el territorio. En Estados Unidos no existe una ley como tal sino que hay un sistema de Tribunal Federal para los casos en que se violan leyes federales y luego cada uno de los estados tiene un sistema para los acusados de vulnerar leyes estatales en sus fronteras. La Constitución tiene prioridad sobre las leyes de cada estado y se aplica por igual en todos ellos pero la legislación de cada estado puede variar siempre que no sea contraria a los derechos constitucionales $^{325}$.

Y, sobre todo, lo que caracteriza el sistema español, es que se pronuncia sobre más aspectos que la culpabilidad o no y que exige una motivación del veredicto, algo que no existe ni ha existido en los otros países. De hecho, en algunos Estados de Estados Unidos y en Canadá es ilegal preguntar a los jurados por las razones de su decisión, incluso para analizar o explicar el veredicto ${ }^{326}$.

\subsubsection{Modelo escabinado.}

Quizás si este fuera el modelo imperante en España, la institución sería menos criticada. En el escabinado, los magistrados y los ciudadanos legos deliberan y votan sobre todas las cuestiones, tanto los hechos, como la parte jurídica, incluso la pena a aplicar. Por una parte, expertos y no

\footnotetext{
${ }^{325}$ Dillehay, Barry-Gabier y Dahir, op. cit., pág. 96.

${ }^{326}$ El art. 648 del Código Penal de Canadá expresa que no se publicará ninguna información y que no cumplirlo es punible. [En línea] [Disponible en: http://www.wipo.int/edocs/lexdocs/laws/en/ca/ca033en.pdf].
} 
expertos participan conjuntamente pero también hay que tener en cuenta que los ciudadanos intervienen en lo concerniente al Derecho, de manera que no hay un veredicto como en España, sino una resolución final que es la sentencia elaborada por todos de manera conjunta. Es el sistema vigente en gran parte de Europa.

El fundamento de este modelo radica en la asunción de responsabilidad por parte de la población y de esa forma justificar su participación en la Administración de Justicia, para que al colaborar los profesionales con los legos, aumente la confianza en el sistema penal y lo acerque a los ciudadanos.

\subsubsection{Alemania.}

Inicialmente, exisían dos tipos de legos, los escabinos (Schöffen), que colaboraban con los jueces profesionales en su función, y los jurados (Geschworene), quienes formaban el Tribunal del Jurado (Schwurgericht), compuesto por tres jueces y doce jurados, que enjuiciaba los delitos capitales, como eran el de alta traición contra el Estado o atentado al Emperador $^{327}$. Con las reformas del Decreto Emminger, el 4 de enero de $1924^{328}$, se modifica la composición y la delimitación de sus funciones.

El jurado se regula en la Ley Orgánica de Tribunales (Gerischtsverfassungsgesetz, $\mathrm{GVG}^{329}$ ). A diferencia de lo que ocurre en España con la Audiencia Provincial, en Alemania no solo se limita a un

${ }^{327}$ Bravo, E. (1888). Ley del Jurado. Madrid: Biblioteca Judicial. [En línea] [Disponible en:

http://www.bibliotecavirtualdeandalucia.es/catalogo/catalogo_imagenes/imagen.cmd?pa th=1005443\&posicion=1].

${ }^{328}$ García Moreno, J. M. (2002). "Los Tribunales de Escabinos en el sistema procesal penal alemán”, en Jueces para la democracia, no 43, pág. 83.

329 Página del Ministerio de Justicia alemán. [En línea] [Disponible en: https://www.gesetze-im-internet.de/gvg/]. 
órgano, sino que el jurado actúa en los procesos penales en primera instancia sobre casi todos los delitos, excepto los relativos a la seguridad del Estado, como traición a la paz, traición a la patria o puesta en peligro de la seguridad exterior, etc., e incluso pueden intervenir en segunda instancia.

Hasta 1975 estaba compuesto por tres jueces profesionales y seis escabinos y posteriormente el número de escabinos se reduce, pasando a tener una doble composición ${ }^{330}$, que rige en la actualidad:

- En los juzgados municipales (Amtsgerichte), uno o dos (si lo solicita el Fiscal) jueces técnicos y dos escabinos.

- En los Tribunales regionales (Landgerichte) la Pequeña Sala de lo Penal, con el Presidente del Tribunal y dos escabinos; y la Gran Sala de lo Penal y en Tribunal del Jurado, con tres jueces técnicos (incluido el presidente y no se puede excluir a ninguno de los profesionales) y dos escabinos.

Su competencia se extiende sobre todo a modalidades de homicidio y otros delitos con resultado de muerte (como abusos sexuales, violaciones, abandono, lesiones, etc.).

El límite de edad es más alto que en España. Los jurados serán personas comprendidas entre los veinticinco y los setenta años (aunque se pueden excusar los mayores de sesenta), que vivan en el municipio correspondiente, dominen el alemán y no tengan problemas de salud. Como en los demás países, no se incluyen el Presidente alemán ni los miembros del Gobierno, también jueces, parlamentarios europeos o profesionales del ámbito sanitario, entre otros. Además lo tienen prohibido los condenados. Los escabinos son elegidos por listas municipales cada cuatro años y

330 Planchadell Gargallo, A., "Los antecedentes históricos del Jurado español”, en Montero Aroca, J. y Gómez Colomer, J. L. (coords.) (1999). Comentarios a la Ley del Jurado. Navarra: Aranzadi, pág. 102. 
reciben una indemnización por el ejercicio de su cargo, el desplazamiento y por pérdida de ingresos. Si no comparecen pueden ser sancionados con pena de multa.

Durante el juicio, el presidente del tribunal dirige la vista y realiza la práctica de la prueba. Los escabinos pueden dirigir preguntas a los testigos, peritos y acusados. La deliberación y la votación también serán dirigidas por el presidente y se requieren distintas mayorías en función de la cuestión que se esté debatiendo ${ }^{331}$ :

- Sobre los presupuestos procesales, por ejemplo en materia de jurisdicción o competencia, se exige mayoría absoluta.

- En cuanto a la culpabilidad, que incluye circunstancias agravantes y atenuantes, así como para la imposición de la pena y su remisión condicional, mayoría de dos terceras partes.

- Respecto a las costas, también mayoría absoluta.

Finalmente la sentencia, que incluye una motivación detallada, solo es firmada por los jueces profesionales y no por los escabinos.

\subsubsection{Francia.}

El primer jurado en el sistema continental se estableció en Francia ${ }^{332}$ y servirá como influencia en el resto de Europa. En este país, el jurado (le jury) se instaura tras la Revolución Francesa, pero no con este modelo. Se establece al aprobarse la Ley sobre Policía de Seguridad, la Justicia

\footnotetext{
${ }^{331}$ García Moreno (2002), op. cit., pág. 94.

332 Arnaldo Cubilla y González Hernández, actualizado por Sieira. [En línea] [Disponible en: http://www.congreso.es/consti/constitucion/indice/sinopsis/sinopsis.jsp?art=125\&tipo=2 ].
} 
Criminal y la Institución del Jurado, de 16-29 de septiembre de $1791^{333}$, en un principio, con la separación entre los hechos y el Derecho, y con un sistema parecido al inglés, con jurado de acusación y de decisión.

Posteriormente, la Ley de 5 de marzo de 1932 establece que, después del veredicto, el Tribunal y el Jurado deliberan y votan conjuntamente sobre la aplicación de la Ley. El jurado, compuesto por doce miembros, resuelve sobre la culpabilidad, y el tribunal, formado por tres jueces, sobre la pena. Este era el modelo mixto.

Será más tarde cuando se pase al sistema de escabinos, con la Ley de 25 de noviembre de 1941, por la que el Jurado y el Tribunal se funden en un único órgano colegiado, el llamado Tribunal de Escabinos, formado por los expertos y los legos. Para elegir a estos jurados, se parte de una lista elaborada anualmente del censo electoral, para mayores de veintitrés años. Hasta 1848, en la lista solo entraban miembros de la alta sociedad. A partir de ese año, se incluye a ciudadanos mayores de treinta años, que sean considerados sujetos prudentes e integrados en la sociedad, lo que perduró hasta 1978.

En la actualidad se regula en el equivalente a nuestra Ley de Enjuiciamiento Criminal, el Code de Procédure Pénale ${ }^{334}$. El resto de condiciones son parecidas a las españolas: saber leer y escribir (en francés), disfrutar de los derechos civiles, políticos y familiares y no estar incurso en una situación de incapacidad (condenados, quebrados, acusados...), incompatibilidad (miembros del Gobierno, del Parlamento, del Consejo de Estado, magistrados, policías...), dispensa (los mayores de setenta años,

\footnotetext{
333 Novo Pérez, Arce Fernández y Seijo Martínez, op. cit., pág. 341.

${ }^{334}$ Arts. 254 a 267. [En línea] [Disponible en:

https://www.legifrance.gouv.fr/affichCode.do?cidTexte=LEGITEXT000006071154\&da teTexte=29990101].
} 
quienes aleguen un motivo grave que se considere válido) o exclusión (si ya han sido jurados en los últimos cinco años).

Con la reforma del Código Procesal de 1957, se establece la Cour d'Assise, con nueve jueces legos y tres magistrados, uno de ellos como Presidente del Tribunal. Tienen competencia sobre los delitos más graves, excepto los cometidos por menores de dieciséis años, y también excluye delitos de alta traición o los cometidos por los Ministros en el ejercicio de sus funciones ${ }^{335}$.

Como sucede en España, tienen derecho a una indemnización por el ejercicio del cargo, el alojamiento y el desplazamiento, pueden formular preguntas a los acusados y a los testigos y se les prohíbe hablar del caso tanto con otros ciudadanos, como con los medios de comunicación. Esta prohibición es aplicable a los legos y a los expertos por igual.

Al ser un tribunal compuesto por profesionales y legos, no son necesarias las mismas instrucciones que en España. La culpabilidad requiere mayoría de ocho $\operatorname{votos}^{336}$ y todos deliberan de forma conjunta también sobre la pena, que necesita asimismo la mayoría absoluta de los votos (para fijar la pena en su grado máximo, se exige un mínimo de ocho). Si la pena es superior a los diez años de prisión, además se pronuncian sobre el periodo durante el que el condenado no puede acogerse a beneficios penitenciarios ${ }^{337}$.

\footnotetext{
${ }^{335}$ Planchadell Gargallo, op.cit., pág. 99.

336 Corcuera Atienza, J. (1995). "La Constitución de 1978 y el jurado", en Revista del Centro de Estudios Constitucionales, $\mathrm{n}^{\circ} 22$, pág. 98.

${ }^{337}$ Planchadell Gargallo, op.cit., pág. 100.
} 


\subsubsection{Italia.}

También tiene su origen en la influencia francesa. El Código de Procedimiento Penal de 1859 estableció el jurado puro, con doce jurados que decidían solamente sobre los hechos, y tres Magistrados, con una competencia amplia, ya que podían juzgar los delitos castigados con pena de prisión superior a los cinco años. Para la culpabilidad se exigía mayoría de ocho votos. Este número se fue modificando hasta que a finales de los años 30 del siglo XX se pasó al sistema escabinado ${ }^{338}$.

En la actualidad, el Tribunal del Jurado (Corte d'Assise) está compuesto por dos magistrados y seis escabinos, seleccionados para un mandato corto y que representan los distintos sectores de la sociedad ${ }^{339}$. Su fundamento figura en el art. 102 de la Constitución italiana ${ }^{340}$ (1947), que exige un desarrollo legal posterior, igual que en ocurre en España. Tiene competencia ${ }^{341}$ en general sobre delitos graves:

- Los que conllevan pena de prisión permanente o no inferior a veinticuatro años. Como en nuestro país, se excluye la tentativa de homicidio. Sin embargo, sí enjuician el homicidio consentido, el auxilio al suicidio y el homicidio preterintencional.

- La trata de personas y delitos dolosos con resultado de muerte, salvo en riñas y en la omisión del deber de socorro.

338 Ibid.

339 [En línea] [Disponible en:

https://e-justice.europa.eu/content_judicial_systems_in_member_states-16-ites.do?member $=1]$.

340 La legge regola $i$ casi e le forme della partecipazione diretta del popolo all'amministrazione della giustizia. (La ley regula los casos y las formas de participación directa del pueblo en la administración de justicia). [En línea] [Disponible en: http://www.normattiva.it/uri-res/N2Ls?urn:nir:stato:costituzione].

${ }^{341} \mathrm{Se}$ regula en el art. 5 del Codice di procedura penale. [En línea] [Disponible en: http://www.normattiva.it/uri-

res/N2Ls?urn:nir:stato:decreto.del.presidente.della.repubblica:1988-09-22;447]. 
- Delitos de genocidio ${ }^{342}$ y contra la seguridad del Estado, siempre que estos últimos no tengan una pena inferior a diez años.

Como en el caso alemán, también pueden intervenir en la apelación, en los tribunales de apelación (Corti d'assise d'appello) ${ }^{343}$. Los requisitos son algo diferentes y más si tenemos en cuenta que tienen competencias en segunda instancia ${ }^{344}$ :

- Ser ciudadano italiano y poseer los derechos civiles y políticos.

- Buen comportamiento moral.

- Edad no inferior a treinta años y no superior a sesenta y cinco.

- Tener estudios medios de primer nivel y si es para el Tribunal de Apelaciones, el título final de la secundaria.

Una diferencia respecto a la forma de elección de los jurados es que hay que inscribirse previamente en la lista para el sorteo, a través de la solicitud al Alcalde del municipio correspondiente ${ }^{345}$. Esto se hace bianualmente en los años impares. Quedan excluidos los jueces, funcionarios de justicia, policías, militares, miembros de congregaciones religiosas y quienes hayan sido jurado en los dos años anteriores. También reciben una remuneración por el ejercicio de su cargo y por desplazamiento, en su caso.

\footnotetext{
${ }^{342}$ Según ese mismo artículo, se contemplan en la Ley no 962 de 9 de octubre de 1967.

${ }^{343}$ Consiglio Superiore della Magistratura. [En línea] [Disponible en: https://www.csm.it/web/csm-internet/magistratura/il-sistema-giudiziario].

${ }^{344}$ Ministerio de Justicia de Italia. [En línea] [Disponible en: https://www.giustizia.it/giustizia/it/mg_3_7_4.page?previsiousPage=mg_14_7].

${ }^{345}$ Art. 14 de la Ley 287, de 10 de abril de 1951 (Riordinamiento dei giudizi de Assise). [En línea] [Disponible en: http://www.normattiva.it/uri-res/N2Ls?urn:nir:legge:195104-10;287].
} 


\subsubsection{Portugal.}

El origen del jurado portugués se encuentra en un Decreto de 16 de mayo de 1832 y desapareció con el Estatuto Judiciario de 23 de febrero de 1944.

La Constitución (1976) lo recoge dentro del Título VI, dedicado a los Tribunales ${ }^{346}$. Además, el art. $13^{347}$ del Código Procesal Penal establece los delitos que son de su competencia ${ }^{348}$, cuando la acusación o la defensa lo solicite $^{349}$ (de lo contrario, el acusado será juzgado por un órgano compuesto exclusivamente por jueces profesionales):

- Los delitos contra la identidad cultural y la integridad personal, como torturas o discriminación racial, religiosa o sexual.

- Delitos contra la seguridad del Estado, como contra la independencia y la integridad nacional, traición a la patria, violación del secreto de Estado, espionaje, etc.

- Delitos previstos en la Ley Penal relativa a las violaciones del Derecho Internacional Humanitario.

${ }^{346}$ Art. 216. "Del jurado".

1. El jurado estará compuesto por los jueces del Tribunal colectivo y por individuos jurados.

2. El jurado intervendrá en el enjuiciamiento de los delitos graves y funcionará cuando lo solicite la acusación o la defensa.

[En línea] [Disponible en:

http://confinder.richmond.edu/admin/docs/portugalsp.pdf].

347 Procuradoria-Geral Distitral del Lisboa. Código de Processo Penal. DL n ${ }^{\circ}$ 78/87, de 17 de febrero. [Disponible en línea]:

http://www.pgdlisboa.pt/leis/lei_mostra_articulado.php?artigo_id=\&nid=199\&tabela=le is\&pagina $=1 \&$ ficha $=1 \&$ so_miolo $=\&$ nversao=\#artigo $]$.

348 Se excluyen los delitos de terrorismo y crimen organizado, según el art. 111 de la Ley $\mathrm{n}^{\circ} 3 / 99$, de 13 de enero, de Organización y Funcionamiento de los Tribunales (LOFTJ). Procuradoria-Geral Distitral del Lisboa. [En línea] [Disponible en: http://www.pgdlisboa.pt/leis/lei_mostra_articulado.php?ficha=101\&artigo_id=\&nid=1 \&pagina $=2 \&$ tabela $=$ leis \&nversao $=\&$ so_miolo $=]$.

349 También regula la competencia el art. 2 del Decreto-Ley $n^{\circ} 387 / 87$, de 29 de diciembre, sobre el régimen del jurado en el proceso penal. 
- Algunos supuestos de delitos castigados con pena superior a ocho años de prisión.

El art. 110 de la Ley de Organización de los Tribunales dispone que el tribunal del jurado está constituido por el presidente del tribunal colectivo, que preside, los demás jueces y los jurados, y se regulará por ley. Esta norma es el DL n ${ }^{\circ}$ 387/87, de 29 de diciembre, sobre el Régimen del Jurado en el Proceso Penal ${ }^{350}$.

El jurado portugués adoptó el modelo escabinado en 1977 y está compuesto por tres jueces (uno de ellos preside), el llamado "tribunal colectivo", y cuatro jurados legos más cuatro suplentes. Todos ellos debatirán de forma conjunta y deciden el veredicto por mayoría simple de votos. Como en el resto del derecho comparado, son seleccionados de la lista electoral. Los requisitos son:

- Tener menos de sesenta y cinco años ${ }^{351}$ (aquí sí hay una diferencia, ya que no es una excusa sino un límite al poder ejercer de jurado).

- Poseer la escolaridad ${ }^{352}$.

- No padecer alguna anomalía física o psíquica que impida el ejercicio del cargo.

- Pleno goce de los derechos civiles o políticos.

${ }^{350}$ Procuradoria-Geral Distitral del Lisboa. [En línea] [Disponible en: http://www.pgdlisboa.pt/leis/lei_mostra_articulado.php?nid=315\&tabela=leis].

${ }^{351}$ Anteriormente, por el art. 1 del D-L no 679/75, de 9 de diciembre, el intervalo de edad era entre veinticinco y setenta años. Se consideraba ese mínimo porque es la edad media del inicio de la magistratura y porque se entiende cierta experiencia de vida. Álvarez Alarcón, A. (1987). "El jurado en Portugal: estatuto, competencia y procedimiento de selección", en Anuario de la Facultad de Derecho. Universidad de Extremadura, no 5 , pág. 253.

${ }^{352}$ El anterior D-L establecía "saber leer en lengua portuguesa", sin hacer más referencia a los estudios necesarios. Lo que se pretendía es que pudieran examinar la prueba documental. 
- No estar presos, detenidos ni condenados.

También se producen las mismas exclusiones que en España, como ser el Presidente, miembro del Consejo de Estado o del Gobierno, Diputado, juez, abogado, policía, militar, docente de Derecho, etc. Tampoco familiares directos ni las partes intervinientes en la causa concreta y pueden excusarse quienes tengan cargas familiares muy gravosas, los que hayan sido jurado en los dos últimos años más de una vez, los ministros de culto (exclusión que figura en numerosos ordenamientos pero no en el español) o los que hayan sufrido en el último mes el fallecimiento de un familiar cercano.

Una cuestión distinta que se regula en Portugal la encontramos en el catálogo de derechos del jurado, así el art. 5 del D-L dispone que, aparte de la compensación económica que también se da en otros países, no pueden ser detenidos mientras dure su función, salvo en caso de flagrante delito que sea castigado con pena de prisión superior a tres años y además tienen derecho a usar y portar armas de defensa, de forma gratuita. No acudir al juicio sin causa justificada se considera delito de desobediencia simple y hacer declaraciones públicas sobre el proceso, conlleva pena de prisión hasta seis meses o multa hasta doscientos días.

\subsubsection{Ventajas e inconvenientes de cada modelo.}

Sobre cuál de los sistemas es mejor, ambos presentan pros y contras. Independientemente del modelo, en general, el jurado se concibe como una institución fortalecedora de la democracia porque es uno de los medios de participación ciudadana en uno de los tres poderes del Estado y esto refuerza el ejercicio de la función jurisdiccional, ya que la ley es expresión de la voluntad popular. 
Sus partidarios alegan como argumentos a favor:

- Así se establece en la Constitución.

- Es una institución establecida prácticamente en todas las democracias del mundo ${ }^{353}$.

- Es consustancial al principio acusatorio y al de la libre apreciación de la prueba.

- Los ciudadanos aportan lógica y experiencia para enjuiciar hechos donde se no se requieren conocimientos técnicos especializados.

- Aproxima la justicia al pueblo, en ocasiones demasiado alejada.

- Existe un claro interés por parte de los ciudadanos en la vida jurídica de la sociedad en la que se encuentran $y$, de esta forma, pueden participar en ella.

- Ser parte de un jurado representa la madurez de los ciudadanos.

- Al encomendar a los iguales el enjuiciamiento de los hechos, se genera una mayor confianza de los ciudadanos en la justicia.

Por otra parte, los detractores argumentan en contra lo siguiente:

- En España la legislación nunca ha prestigiado la institución, que ha fracasado históricamente, con continuos establecimientos y derogaciones.

\footnotetext{
353 "Son muchos los autores que afirman que es difícil encontrar un modelo de democracia avanzada sin contar con alguna versión más o menos tamizada de la participación del pueblo en la Administración de Justicia. (...) la participación de los ciudadanos en labores jurisdiccionales es relevante para la propia democracia". Marín Gámez, J. Á. (2003-2004). "Ocho años de Tribunal del Jurado", en Revista de derecho político, nº 58-59, pág. 692.
} 
- Un país no es no democrático por no tenerlo (por ejemplo los Países Bajos).

- Consideran imposible poder separar el hecho del Derecho.

- La falta de formación jurídica de los ciudadanos para juzgar delitos de esas características.

- Se exige un gran esfuerzo al ciudadano al ser un deber, lo que le impide realizar su vida laboral y familiar de manera normal.

- Es caro (pago de dietas por día, más alojamientos y desplazamientos) y no es necesario invertir dinero en eso.

- El esclarecimiento de los hechos en muchas ocasiones no es sencillo.

- El ciudadano puede estar interesado en determinados hechos más que en otros, lo que le genera poca objetividad.

- La experiencia que aportan puede no ser tal si tienen un conocimiento de la vida limitado.

- Hay un mayor riesgo de politización.

En España, la Constitución no hace referencia a qué modelo debe implantarse $^{354}$ y se optó por el jurado puro, ni siquiera fue una cuestión importante en los debates previos en las sesiones del Congreso ${ }^{355}$. La

\footnotetext{
${ }^{354}$ La decisión del modelo se delegó por la CE en el legislador ordinario, lo que dio lugar, durante los diecisiete años que pasaron desde la aprobación de la CE hasta la de la LOTJ, a numerosos estudios sobre cuál imponer. La elección del sistema puro, para González García es audaz, ya que este modelo se encuentra en regresión en los ordenamientos más cercanos al nuestro, como Alemania, Francia e Italia, aunque probablemente sea por lo regulado en nuestro derecho histórico. González García, J. Ma , "La opción por el jurado de jueces legos", en de la Oliva Santos, A. (coord.) (1999). Comentarios a la Ley del Jurado. Madrid: Centro de Estudios Ramón Areces, pág.93.

${ }^{355}$ Finalmente el legislador otorga al jurado español de una serie de particularidades, como es la motivación del veredicto, para garantizar la constitucionalidad de su régimen jurídico y superar las dificultades que históricamente se ha encontrado esta institución en nuestro ordenamiento. Por eso algunos autores como Ortiz Úrculo, Pérez-Cruz Martín y Narváez Rodríguez lo consideran mixto, al diferenciarse en algunos aspectos del puro anglosajón pero sin ser escabinado. Bermúdez Requena, J. M. (2008). Tribunal
} 
ventaja es la separación entre el hecho y el Derecho para que los ciudadanos legos no tengan que pronunciarse sobre cuestiones jurídicas y de esta forma sean los profesionales quienes se encarguen de esa parte.

Por otra parte, los jurados escabinados tienen a favor la posibilidad de deliberación conjunta, lo que facilita la labor que deben ejercer los ciudadanos pero también pueden verse influidos por la opinión de los profesionales ${ }^{356}$ y además participan también en los criterios estrictamente jurídicos e intervienen en la propia sentencia. Frente a esto, no olvidemos que en España están asistidos en todo momento por el MagistradoPresidente para que les resuelva cualquier duda que puedan transmitirle. Hay un sector doctrinal que considera difícil la separación entre el hecho y el Derecho y que con el jurado escabinado se corregiría ese defecto ${ }^{357}$ y además se cumpliría con la exigencia constitucional de que las sentencias sean motivadas. Sin embargo, España añade un requisito que no existe en los otros países, que es la motivación del veredicto, hecho que, junto con la posibilidad de devolución del acta si existe algún defecto, hace que esta última necesidad quede cubierta.

Otra cuestión que se plantea es si el jurado puro juzga menos cantidad de delitos que el escabinado aunque hemos visto que depende de los países. Por ejemplo, en España sí está restringido a determinados delitos, a pesar de que no es una lista cerrada y es susceptible de ampliación, pero en Estados Unidos, que sigue el mismo modelo, se

del jurado. Modelo y proceso. Evolución legislativa en el ordenamiento jurídico español. Valencia: Tirant, pág. 5.

${ }^{356}$ Yáñez Velasco afirma que "hay que dudar que un magistrado pueda cambiar su pensamiento ante los argumentos legos. El juez técnico tendrá, aunque no lo pretenda, una posición dirigente (...) su presencia puede reducir la participación de los miembros del Jurado". Yáñez Velasco, R. (2014). La institución del jurado. Introducción a su estudio psicosocial. Madrid: Reus, pág. 149.

357 Javier Corcuera Atienza habla de la existencia de una mayoría, entre los procesalistas, partidaria del escabinado. Corcuera Atienza, op. cit., pág. 118. 
extiende a todos los delitos, mientras que en el modelo escabinado, Portugal lo delimita a los casos más graves y otros estados como Alemania, lo aplican a numerosos delitos.

Existen autores, como Manzanares Samaniego, apoyado por otros como Gimeno Sendra o Ramón Soriano, que consideran preferible el modelo escabinado porque combina la experiencia del juez con la opinión del ciudadano en la cuestión debatida. Por otra parte, se inclinan por el jurado puro otros como López-Muñoz Larraz, por ser la máxima expresión de la soberanía popular y permite huir de un poder judicial en ocasiones excesivamente profesionalizado y alejado de la realidad social ${ }^{358}$.

Si en España rigiera este último modelo, tal vez el jurado tendría menos detractores aunque la separación entre las cuestiones de hecho y las jurídicas quizás supongan una ventaja frente a dicho sistema. En todo caso, coincidimos con un informe del Consejo General del Poder Judicial, de 7 de abril de 1994, que expone: "No parece, pues desacertado comenzar la reforma del proceso penal con la instrucción del Jurado. El jurado obliga a dar primacía al Juicio oral y refuerza el protagonismo de las partes. (...) La utilidad del jurado (...) estriba en que el titular del Poder Judicial -el pueblo- va a intervenir en su ejercicio y en que esa intervención va a cambiar los contenidos y las formas de actuación del tercer poder del Estado: un poder cada vez más fuerte del que los ciudadanos, en un sistema democrático, no pueden quedar excluidos"359.

\footnotetext{
${ }^{358}$ Narváez Rodríguez, A. (1995). El jurado en España. Granada: Comares, pág. 4. ${ }^{359}$ Informe al Anteproyecto de LOTJ, citado por Corcuera Atienza, op. cit., pág. 129. 


\subsection{Historia del jurado en España.}

4.2.1. Situación en España a comienzos del siglo XIX hasta el desarrollo de la primera ley específica.

Los ciudadanos ya formaban parte del jurado en la antigua Grecia y en los iudicia publica del Derecho Romano, base de nuestro sistema jurídico, donde el criterio para juzgar unos delitos u otros era el mismo que el actual, la posible complejidad del caso $^{360}$.

Nuestra legislación lo adopta como consecuencia de la influencia del derecho comparado, especialmente de la francesa, ya que el primer jurado en el sistema continental se establecerá en Francia ${ }^{361}$ con la Ley de 29 de septiembre de 1791, no sin dificultades ni objeciones anteriores: gran número de Magistrados y muchas corporaciones judiciales se inclinaron en Francia a la abolición del Jurado ${ }^{362}$, donde se instauró a pesar de la oposición de los cuerpos judiciales. Su surgimiento es debido a los grandes movimientos políticos: en Francia con la revolución de 1789; en Alemania durante el periodo de libertad inaugurado en 1848; en Italia a medida que se realizaba su regeneración política y nacional; así como en España se inició nuevamente en 1812, 1854 y $1869^{363}$.

\footnotetext{
${ }^{360}$ Kunkel explica que "la política y la administración se habían complicado tanto que el ciudadano medio, en muchos casos, ya no era capaz de enjuiciar las circunstancias del delito". Kunkel, W. (1989). Historia del derecho romano. Barcelona: Ariel (9a ed.), pág. 73.

${ }^{361}$ Arnaldo Cubilla y González Hernández, op. cit.

362 Proyecto de Ley que establece el Tribunal del Jurado en materia criminal: Gaceta de Madrid, de 9 de febrero de 1883. [En línea] [Disponible en: https://www.boe.es/datos/pdfs/BOE/1883/040/R00292-00304.pdf]. ${ }^{363}$ Ibid.
} 
$\mathrm{Al}$ contrario que en los países anglosajones ${ }^{364}$, en España nos hemos encontrado con el jurado de forma discontinua, en función del contexto histórico, durante los siglos XIX y XX, por lo que no se le otorga la continuidad necesaria para establecerse política y socialmente.

Con la gran codificación del siglo XIX llegan también las primeras menciones en las Constituciones españolas, con el antecedente del Estatuto o Carta de Bayona, otorgado en 1808 por José Bonaparte ${ }^{365}$. En su Título XI "Del orden judicial", el art. 106, siguiendo el modelo francés, refiere que El proceso criminal será público. En las primeras Cortes se tratará de si se establecerá o no el proceso por jurados.

Más tarde, la primera Constitución (1812) ${ }^{366}$ también hace una breve referencia, al permitir la posibilidad de crear estos tribunales, a través del art. $307^{367}$ : Si con el tiempo creyeren las Cortes que conviene haya distinción entre los jueces del hecho y del derecho, la establecerán en la forma que juzguen conducente. Como en la actualidad, necesitará un desarrollo legal posterior para que efectivamente haya jurados pero ya

\footnotetext{
${ }^{364}$ Como se ha expuesto en el apartado dedicado al derecho comparado, la Constitución de Estados Unidos contempla la institución del jurado desde sus inicios, en 1787, y para todos los delitos, al contrario que en España, con la lista específica de delitos establecidos por la ley, que, aunque no sea fija y esté abierta tanto a inclusiones como a exclusiones, en realidad son muy pocos los delitos competencia de este tribunal. En la sociedad americana sí está mucho más arraigado puesto que lo han vivido siempre y no de forma intermitente y breve como en nuestro país, a pesar de que el modelo que se sigue en España es precisamente el sistema puro o anglosajón, aunque no se desarrolle exactamente igual que en Estados Unidos.

${ }^{365}$ Ignacio Fernández Sarasola explica que "fue una Carta Otorgada, a través de la cual Napoleón trató de institucionalizar un régimen autoritario, pero con un reconocimiento básico de libertades". Fernández Sarasola, I. (2006). "La primera constitución española", en Revista de derecho: División de Ciencias Jurídicas de la Universidad del Norte, n 26, pág. 90.

${ }^{366}$ Constitución Española de 19 de marzo de 1812, reimpresa en la Imprenta Nacional de Madrid (1820).

${ }^{367}$ En el Título V, "De los Tribunales y de la Administración de Justicia en lo civil y en lo criminal”, Capítulo III, "De la administración de justicia en lo criminal”.
} 
habla de la diferenciación entre el hecho y el derecho y, por lo tanto, a quienes juzgan uno u otro ámbito.

Sobre esa base, será en 1820 cuando se cree el primer jurado popular en nuestro país y entonces su competencia se limitaba a juzgar los delitos de imprenta y los electorales. El legislador tardaría bastante más tiempo en regular esta materia pero hubo múltiples intentos a lo largo de los años sucesivos. Después de esto el jurado estaría vigente de manera intermitente.

Como ya hemos comentado, la institución no tenía una vigencia extensa y únicamente duró hasta 1823, ya que con la restauración del absolutismo se derogó la libertad de imprenta, dado que por aquel entonces aún no se había aprobado una ley del jurado, por lo que estos preceptos se recogían en la Ley sobre la libertad de imprenta, de 22 de octubre de $1820^{368}$, al ser estos delitos los que se sometían a dicho tribunal. El legislador consideró que los delitos cometidos por medio de la imprenta debían ser juzgados por los hombres, además de por la ley. Estos eran los que se cometían con "abusos" y se refería a artículos calificados como subversivos $^{369}$, sediciosos ${ }^{370}$, incitadores a la desobediencia ${ }^{371}$, obscenos o infamatorios ${ }^{372}$.

En las Cortes se debatían estas cuestiones entre partidarios y detractores del jurado. Los defensores entendían que implantar el jurado era una garantía de la libertad pero, consideraban que quizás era pronto para establecerlo en España o que los delitos de imprenta no eran los más

\footnotetext{
${ }^{368}$ En el Título VII "Del modo de proceder en estos juicios" (arts. 36-74).

${ }^{369} \mathrm{El}$ art. 6 considera delictivos los impresos que conspiren contra la religión del Estado o la Constitución. Bermúdez Requena (2008), op. cit., pág. 21.

${ }^{370}$ Doctrinas dirigidas a excitar la rebelión o la perturbación de la tranquilidad pública. Ibid.

${ }^{371}$ Escritos que inciten a desobedecer alguna ley o autoridad legítima. Ibid.

${ }^{372}$ Los que injurien, mancillen el honor y la reputación de alguien. Ibid.
} 
idóneos ${ }^{373}$. Además se daba la circunstancia de que aún no se había aprobado el Código Penal que llegaría en 1822 y los diputados pensaban que podía ser preferible que los delitos competencia del jurado fueran los menos complejos en lo que respecta a los hechos, como ocurre ahora: robos, asesinatos, cohechos, etc. También fue objeto de discusión el sistema de unanimidad o de mayorías a la hora de emitir el veredicto, y llegaron a la conclusión de que es más ventajosa la mayoría al ser ciudadanos legos para que los delitos no queden impunes por un único voto.

Al igual que en la Constitución, la ley de imprenta se refería a sus miembros como "jueces de hecho" ${ }^{\text {"374 }}$. Para cada caso se seleccionaba un jurado y tenían más funciones que en la actualidad, puesto que también decidían si había lugar o no a la causa, lo que se llamaba jurado de acusación, compuesto por nueve miembros. Posteriormente los que ya se encargaban de juzgar, constituían el jurado de calificación ${ }^{375}$ y en esta ocasión eran doce y emitían lo que hoy en día sería el veredicto, entonces llamado "la calificación". Por su parte, el juez era quien aplicaba la pena. Mientras se esperaba a la aprobación de alguna ley sobre la materia, esta es la que se aplicaba a pesar de que el jurado no permaneciera de forma

\footnotetext{
373 ... la institución de Jurados tan ventajosa en Inglaterra, podrá tal vez no serlo ahora en España; no se debe introducir entre nosotros, sin antes hacer alguna prueba de los efectos que causa prácticamente y de cómo es recibida por el pueblo (...) es muy peligroso hacer esta prueba precisamente en una materia de las más difíciles y delicadas que hay en la legislación criminal, cual es la calificación de ideas y opiniones manifestadas por escrito. Diario de Sesiones de Las Cortes, $\mathrm{n}^{\circ}$ 84, de 26 de septiembre de 1820, pág. 1259. Página del Congreso de los Diputados. [En línea] [Disponible en: http://www.congreso.es/est_sesiones/].

${ }^{374}$ Eran elegidos por los Ayuntamientos de las capitales de provincia cada año, de entre los ciudadanos en el ejercicio de sus derechos, mayores de veinticinco años y con residencia en la capital.

${ }^{375}$ Marcuello Benedicto, J. I. La libertad de imprenta y su marco legal en la España liberal. [En línea] [Disponible en: http://www.juntadeandalucia.es/educacion/vscripts/w_bcc1812/w/rec/4240.pdf]. 
continua, dado que aún no tenía el suficiente arraigo no solo social sino tampoco político ni jurídico ${ }^{376}$.

La Constitución de $1837^{377}$ hace referencia a la libertad de imprenta y al jurado ${ }^{378}$ y pocos años más tarde se promulgó la Ley sancionada sobre la formación del jurado en las capitales de provincia, de 20 de julio de $1842^{379}$.

Durante los siguientes años, como ya se ha comentado, el tribunal del jurado se va derogando y restableciendo en diferentes periodos con una vigencia muy corta en todos ellos: desaparece en 1845, cuando la Constitución deja de regularlo y por un Decreto se suprime definitivamente. Se instituye nuevamente en $1852^{380}$ pero solamente hasta

\footnotetext{
${ }^{376}$ Cuando se restaura, se sigue aplicando la ley de 1820. A modo de ejemplo de este sistema, uno de los delitos de imprenta sometidos a juicio el 1 de octubre de 1836, en los que el "primer juez de hecho nombrado, leyó en voz alta la calificación, poniéndola enseguida en manos del Sr. juez". El jurado declaró al acusado "absuelto" -entonces no existía el veredicto de culpabilidad o inculpabilidad- y la sentencia así lo manifestó "habiéndose observado en este juicio todos los trámites prevenidos por la ley y calificado los 12 jueces con la fórmula de absuelto". Sentencia publicada el 4 de octubre de 1836 en la Gaceta de Madrid, páginas 3 a 4. BOE [En línea] [Disponible en: https://www.boe.es/datos/pdfs/BOE//1836/662/A00003-00004.pdf].

${ }^{377}$ Constitución de 1837. [En línea] [Disponible en: http://www.juntadeandalucia.es/educacion/vscripts/w_bcc1812/w/rec/4131.pdf].

${ }^{378}$ El art. 2 dispone: Todos los españoles pueden imprimir y publicar libremente sus ideas sin previa censura, con sujeción a las leyes. La calificación de los delitos de imprenta corresponde al jurado. También establecerá en el art. 1 de sus artículos adicionales que Las leyes determinarán la época y el modo, en que se ha de establecer el juicio por jurados para toda clase de delitos y de esta forma prever la posibilidad de que se aumentara la competencia de este tipo de tribunal.

${ }^{379}$ Establece que serán jueces de hecho los mayores contribuyentes por contribuciones directas en cualquier punto del reino que estas se paguen, y que reúnan las demás circunstancias requeridas por la ley (art. 1). Gaceta de Madrid, de 20 de julio de 1842. BOE [En línea] [Disponible en: https://www.boe.es/datos/pdfs/BOE//1842/2840/A00001-00001.pdf].

${ }^{380}$ Mediante RD de 2 de abril de 1852, que reforma las disposiciones vigentes en materia de imprenta y afectará a los escritos que atenten contra el orden público, la sociedad o la autoridad. Bermúdez Requena (2008), op. cit., pág. 27.
} 
1856, año en que vuelve a desaparecer ${ }^{381}$. Después una vez más se instaura entre 1864 y $1867^{382}$.

La Constitución de $1869^{383}$ vuelve a regularlo y determina que Se establecerá el juicio por jurados para todos los delitos políticos, y para los comunes que determine la ley. La ley determinará también las condiciones necesarias para desempeñar el cargo de jurado ${ }^{384}$. Sigue habiendo, por tanto, referencias constitucionales y mandato de desarrollo legal posterior pero este aún tardaría en llegar como materia específica. El 15 de septiembre de 1870 se publicó la Ley Provisional sobre Organización del Poder Judicial que trata este asunto ${ }^{385}$. En el art. 13 de nuevo figura la separación entre jurados populares y profesionales: Una ley especial hará la división judicial en conformidad a lo prescrito en el art. $11^{386}$ de la presente ley. (...) se designarán, además (...) las poblaciones en que puedan constituirse:

${ }^{381}$ La institución desaparece de nuevo a pesar de que figura en la Constitución no promulgada de ese año, que al final de su art. 3 expone: La calificación de los delitos de imprenta corresponde a los jurados. Como hizo la de 1837, también contempla que Las leyes determinarán la época y el modo en que ha de establecerse el juicio por jurados para toda clase de delitos, en el art. 73 y con idéntica redacción a la dada años atrás. Constitución no promulgada de 1856. [En línea] [Disponible en: http://www.cepc.gob.es/docs/constituciones-espa/1856.pdf?sfvrsn=2].

${ }^{382}$ Con el proyecto de Ley de imprenta de 29 de marzo de 1967 se suprime el jurado al atribuir el conocimiento de esos asuntos a los jueces técnicos (arts. 34-36). Planchadell Gargallo, op. cit., pág. 135.

${ }^{383}$ Constitución de 1869. [En línea] [Disponible en: http://www.congreso.es/docu/constituciones/1869/1869_cd.pdf].

${ }^{384}$ Art. 93, dentro del Título VII, relativo al poder judicial.

385 Título Primero "De la planta y organización de los Juzgados y Tribunales", Capítulo Primero "De la división territorial en lo judicial, y de los Juzgados y Tribunales".

Gaceta de Madrid, de 15 de septiembre de 1870. BOE [En línea] [Disponible en: http://www.boe.es/datos/pdfs/BOE//1870/258/A00002-00005.pdf].

${ }^{386}$ Divide España, para efectos judiciales, de mayor a menor, en: distritos, partidos, circunscripciones y términos municipales. 
1. ${ }^{\circ}$ Salas ordinarias de Audiencia para juzgar de las causas por delito en las que las Audiencias deban conocer con intervención del Jurado $^{387}$.

2. ${ }^{\circ}$ Salas extraordinarias de Audiencia para juzgar de las causas por delitos comunes, que siendo ordinariamente de las atribuciones de las Audiencias, sin intervención del Jurado, puedan verse en Tribunales presididos por un Magistrado.

A lo largo de su articulado menciona este tipo de tribunal en varias ocasiones más ${ }^{388}$ y en el art. $55^{389}$ se regula que se constituirán Salas de lo criminal en las poblaciones designadas en la ley de división judicial (...) para juzgar las causas en que deba intervenir el Jurado. Dentro de las atribuciones de las Salas de lo criminal de las Audiencias, el art. 276, concreta en qué casos intervendrá el jurado. Todavía serán pocos pero ya aumenta los delitos que puede juzgar:

- Delitos a los que las leyes señalen pena superior al presidio mayor $^{390}$ en cualquiera de sus grados.

- Lesa majestad, rebelión y sedición.

\footnotetext{
${ }^{387}$ El jurado estaba compuesto por doce jueces legos y su función se entendía como un derecho y no como un deber, además de tres magistrados que tenían determinadas facultades sobre los jurados, como el derecho de inspección y veto. Planchadell Gargallo, op. cit., pág. 136.

388 Por ejemplo, el art. 14 dispone que, para señalar las poblaciones, una de las circunstancias a tener en cuenta, es el tener por lo menos el suficiente número de personas que reúnan las cualidades necesarias para ser jurados, atendidas las condiciones de capacidad que la ley exija, y la facultad de recusarlos, la facilidad de alojamiento y la proporción de un edificio adecuado para la celebración de los juicios.

${ }^{389}$ En el Título Primero "De la planta y organización de los Juzgados y Tribunales", Capítulo IV "De las Audiencias", constituidas entonces de forma diferente, ya que no había una por provincia sino que cada una de ellas ejercía su jurisdicción sobre varias provincias cercanas. Las existentes radicaban en Albacete, Barcelona, Burgos, Cáceres, La Coruña, Granada, Madrid, Oviedo, Las Palmas, Palma, Pamplona, Sevilla, Valencia, Valladolid y Zaragoza, como se indicaba en el art. 39 de la propia Ley.

${ }^{390}$ Pena de 6 años y un día a 12 años, según el art. 29 del entones recientemente aprobado Código Penal de 1870. BOE [En línea] [Disponible en:

http://www.boe.es/datos/pdfs/BOE//1870/243/A00009-00023.pdf].
} 
El Título XIII, correspondiente a las disposiciones transitorias, establece que el Gobierno procederá a reformar los procedimientos criminales, entre otros, el procedimiento para el castigo de los delitos en que haya de intervenir el Jurado con las Audiencias ${ }^{391}$, así como la organización del Jurado de modo que por sus condiciones de capacidad e imparcialidad, asegurada por el derecho de recusación, satisfaga las exigencias de la justicia ${ }^{392}$.

Continuando con el mandato de esta ley, el 16 de julio de 1872, se promulgó el Decreto de creación de una Comisión especial para la formación de un proyecto de Ley de Enjuiciamiento criminal y organización del Jurado y nombrando los individuos que han de componerlo $^{393}$ y se expone la dificultad comentada con la que se encuentra el jurado en España ${ }^{394}$. Al tener varios asuntos que tratar, lo que se pretende con esta norma es crear comisiones específicas para cada materia, formadas por expertos en cada una de ellas, de manera que, al ocuparse solamente de un asunto, todo avance con más rapidez ${ }^{395}$.

Además de la importante normativa sobre organización del poder judicial, otra materia que debía tratarse con urgencia era la de los procesos

\footnotetext{
${ }^{391}$ Disposición Transitoria I.3.f), dentro del Título XXIII.

392 Disposición Transitoria I.3.i), dentro del Título XXIII.

${ }^{393}$ Este Decreto menciona en la Exposición que En la actualidad se hallan pendientes varias reformas cuya necesidad es cada día más notoria, descollando entre ellas la institución del Jurado, que es de urgencia suma, puesto que tiende a dar aplicación práctica a uno de los más trascendentales preceptos de la Constitución del Estado. Gaceta de Madrid, de 16 de julio de 1872. BOE [En línea] [Disponible en: http://www.boe.es/datos/pdfs/BOE//1872/198/A00149-00149.pdf].

${ }^{394}$ El Gobierno de V. M. se ha comprometido solemnemente a llenar en un breve plazo el vacío que ocasiona la falta de esta institución, tantas veces prometida y siempre relegada a un lamentable olvido.

${ }^{395} \mathrm{El}$ art. 1 del Decreto nombra una Comisión especial para la formación de un proyecto de Ley de Enjuiciamiento criminal y organización del Jurado, nombrando en el art. 2 a los individuos que compondrán dicha Comisión, entre ellos como Presidente, al entonces Ministro de Gracia y Justicia, D. Nicolás María Rivero, además de un Vicepresidente y seis Vocales.
} 
penales, lo que llegará el 24 de diciembre de 1872, cuando se publica la Ley Provisional de Enjuiciamiento Criminal ${ }^{396}$, con vigencia desde el 15 de enero de 1873, que, a falta de una ley específica, desarrolla este tipo de procedimiento, a pesar de que en aquel entonces la mayoría de los Magistrados y de la sociedad estaban en contra de esta institución ${ }^{397}$ y de la necesidad de remodelación de las salas para adaptarlas a los nuevos procedimientos $^{398}$.

El apartado dedicado expresamente a este proceso es dentro del Libro Segundo ${ }^{399}$ y en el art. $661^{400}$ regula los delitos de los que conocía ${ }^{401}$, incluyendo los conexos, la complicidad y el encubrimiento de todos ellos.

\footnotetext{
${ }^{396}$ Gaceta de Madrid de 24 de diciembre de 1872. BOE [En línea] [Disponible en: https://www.boe.es/datos/pdfs/BOE/1872/359/R00949-00981.pdf].

${ }^{397}$ Bravo, op. cit., pág. 62.

${ }^{398}$ Por ejemplo, regula cuestiones como que en las sentencias En párrafo separado, que comenzará con la palabra "Visto", se insertará literalmente el veredicto del Jurado o que se expresarán -en párrafos también separados y numerados-, que principiarán con la palabra "Considerando", los fundamentos legales que se estimen procedentes para la aplicación de las leyes a los hechos que el Jurado hubiese declarado probados (art.
} 88).

399 "Del juicio oral", Título IV "Del juicio oral ente el Jurado". El Título III lo dedica al juicio oral "ante los Tribunales de derecho", haciendo una vez más la separación entre lo que denomina jueces de hecho y de derecho. Este Título IV ocupa desde el artículo 658 al 785 y establece la composición del tribunal en doce jurados más tres magistrados y que los jurados declararán la culpabilidad o inculpabilidad del procesado respecto de los delitos que fueren objeto de la acusación y de la defensa y también por un delito menos grave que el objeto de la acusación. Los Magistrados, por su parte, imponían las penas y determinaban la responsabilidad civil.

${ }^{400}$ Los que llevaran aparejada una pena mayor a la de presidio mayor; delitos contra la Constitución: de lesa Majestad, contra las Cortes, el Consejo de Ministros y contra la forma de Gobierno; delitos cometidos por los particulares con ocasión del ejercicio de los derechos individuales garantizados por la Constitución (como los cometidos en reuniones, manifestaciones o asociaciones); cometidos por los funcionarios públicos contra el ejercicio de los derechos individuales sancionados por la Constitución; delitos relativos al libre ejercicio de los cultos; rebelión: alzarse públicamente en abierta hostilidad contra el Gobierno, con determinados fines, como destronar al Rey, impedir la celebración de elecciones, disolver las Cortes, etc.; sedición: alzarse pública y tumultuariamente para conseguir por la fuerza o fuera de la legalidad unos objetivos concretos, como impedir promulgar leyes o que una autoridad ejerza sus funciones; delitos penados en la ley electoral; y los cometidos por medio de la imprenta, grabado u otro medio mecánico de publicación, excepto injurias y calumnias contra particulares.

${ }^{401}$ Todos los delitos según el CP de 1870, vigente al aprobarse esta Ley. 
Aumentan respecto a la regulación anterior pero no figuran muchos de los que se juzgan hoy, como el homicidio, las lesiones o la malversación. También establece los requisitos para ejercer el cargo $^{402}$ y las exclusiones $^{403}$.

Cada Junta elaboraba dos listas, una de "capacidades", es decir, de las personas que cumplían los requisitos, y la otra de los jefes de familia ${ }^{404}$. El Tribunal del Jurado se reunía una vez al trimestre ${ }^{405}$. Se constituían los que se pudiera en función del número de Magistrados de la Sala de lo criminal de la Audiencia, calculando las causas que se preveían dicho trimestre ${ }^{406}$.

La Ley también establecía la fórmula que se realizaba en el juicio ${ }^{407}$. Negarse implicaba pena de multa y, si persistía, debía ejercer igualmente el

\footnotetext{
402 Ser español, mayor de treinta años, gozar de los derechos civiles y políticos, saber leer y escribir, ser vecino en el término municipal correspondiente y ser cabeza de familia, con casa abierta, en las listas que deberán formarse en cada uno de los términos municipales. Cabía la posibilidad de no cumplir este último requisito, si tenían un título profesional o habían desempeñado un cargo de Jefe de Negociado de Administración.

${ }^{403}$ Los impedidos física e intelectualmente, procesados, sentenciados, quebrados no rehabilitados, concursados y los deudores a fondos públicos como segundos contribuyentes. Además era incompatible con cualquier otro cargo del poder judicial, fiscales, el servicio militar, algunos empleos civiles y administrativos, maestros de escuela y médicos titulares de los municipios. Y lógicamente, lo tenían prohibido los intervinientes en el proceso y familiares directos. Por su parte, podían excusarse los mayores de sesenta años, los que necesitaran su trabajo para subsistir, Ministros de culto y los que ya hubieran sido jurados en el año anterior.

${ }^{404}$ Dicha Junta estaba compuesta por el Juez y el Fiscal municipales, el Alcalde y tres Concejales del Ayuntamiento. Las listas se podían recurrir y se remitían a los Jueces municipales y a la Audiencia. Cuando eran definitivas se notificaban a los elegidos y se publicaban en el Boletín oficial.

${ }^{405}$ En los periodos octubre-diciembre, enero-marzo, abril-junio y julio-septiembre.

406 A diferencia de la regulación vigente, no se celebraban todos los juicios en la Audiencia, sino que, según el art. 701, dependiendo de la facilidad de las comunicaciones para los jurados y las partes, podía ser la capital (con preferencia) o ciudades importantes y, si no, podía ser la capital del partido al que correspondiera la causa.

${ }^{407}$ Una vez formados los doce miembros, el Presidente les preguntaba “¿Juráis por Dios desempeñar bien y fielmente vuestro cargo, examinando con rectitud los hechos en que se funde la acusación contra los procesados M.N., apreciando sin odio ni afecto las
} 
cargo y al finalizar el juicio se le procesaba por desobediencia ${ }^{408}$. En el juicio se practicaban las pruebas y después el Presidente les preguntaba si necesitaban alguna instrucción sobre cualquier punto objeto del juicio para que lo manifestasen en ese momento y hacía un resumen de las pruebas ${ }^{409}$. Tras dicho resumen, el Presidente formulaba a los jurados las preguntas que ellos tenían que resolver según las conclusiones definitivas de la acusación y de la defensa, además de otra pregunta por cada circunstancia eximente, atenuante o agravante ${ }^{410}$. El juez no podía hacer cuestiones acerca de la culpabilidad del procesado por un delito más grave que el que hubiera sido objeto de la acusación ni sobre la responsabilidad civil.

Una vez entregadas las preguntas a los doce jurados, se retiraban a deliberar y también en ese momento podían consultar cualquier duda o solicitar aclaraciones al Tribunal. Finalmente votaban en voz alta contestando a cada pregunta con "sí" o "no", función en la que no podían abstenerse, bajo pena de multa ${ }^{411}$. En todo caso, la abstención se contaba

pruebas que se os dieren, y resolviendo con imparcialidad, si son o no responsables por los delitos de que se les acusa?" Tras esto, de dos en dos se acercaban a la mesa del Presidente y contestaban "Sí juro", con la mano derecha sobre los Evangelios. Terminaba el juramento con el Presidente diciendo "Si así lo hiciereis, Dios y vuestros conciudadanos os lo premien, y si no, os lo demanden". (Art. 733 de la Ley).

${ }^{408}$ Este delito era castigado con multa y con pena de arresto mayor (de un mes y un día a seis meses), según el art. 29 del CP de 1870.

${ }^{409}$ También resumía los informes, tanto del Ministerio fiscal como de las partes, y de lo expresado por los procesados, sin revelar su opinión, extremo muy importante a la hora de separar con claridad las funciones del jurado y del juez. Debía explicar a los miembros del jurado la naturaleza jurídica de los hechos y determinar las circunstancias constitutivas del delito, así como exponer la doctrina jurídica sobre las agravantes, atenuantes y eximentes. Este resumen fue suprimido en legislaciones posteriores y en la actualidad no se realiza, sino que se hace un cuestionario. La figura es típica del derecho anglosajón, donde el Magistrado sí elabora el llamado summing up.

${ }^{410}$ La fórmula era "¿M.N. es culpable del delito de...?" (o en sus modalidades de tentativa, complicidad, encubrimiento, etc.).

${ }^{411}$ El art. 383 del CP de 1870 tipificaba una de las modalidades de desobediencia: $E l$ que rehusare o se negare a desempeñar un cargo público de elección popular sin presentar ante la Autoridad que corresponda excusa legal, o después que la excusa fuese desatendida, incurrirá en la multa de 150 a 1500 pesetas. 
como voto para la inculpabilidad, igual que ahora. La mayoría absoluta de los votos formaba veredicto y lo curioso es que en caso de empate decidía el Presidente del jurado, cargo que correspondía al primer seleccionado en el sorteo, salvo que la mayoría eligiese a otro. En el presente no puede producirse este empate debido a que el jurado actualmente está compuesto por nueve personas.

Se redactaba un acta, que firmaban todos los jurados, con el resultado de la votación La negativa se castigaba como delito de desobediencia y también estaba penado revelar el voto, propio o de un compañero $^{412}$.

Se dictaba sentencia condenatoria o absolutoria en función del veredicto y contra este únicamente cabía recurso de reforma por el mismo Jurado o el de revista de la causa por nuevo Jurado ${ }^{413}$. La sentencia también se podía recurrir en casación por infracción de 1 ley ${ }^{414}$, lo que se regulaba de manera separada a la regulación del recurso de casación contra las

En la misma pena incurrirá el Jurado que voluntariamente dejare de desempeñar su cargo sin excusa admitida.

${ }^{412}$ A estos efectos se consideraba como un delito de violación de secretos cometido por un funcionario público, sancionado con pena de suspensión en su grado mínimo y medio y multa de 150 a 1500 pesetas.

${ }^{413}$ Las causas por las que se podía interponer ese recurso eran: no haber contestado categóricamente alguna de las preguntas, entonces se volvían a retirar a deliberar para resolver la pregunta impugnada; si existía contradicción o falta de coherencia en las contestaciones, en cuyo caso debían contestarlas de nuevo, haciéndoles ver los jueces qué defectos tenían las primeras contestaciones; que el veredicto se excediera de los límites de la contestación categórica a las preguntas formuladas; y otros defectos de incumplimiento de las normas, como no deliberar a puerta cerrada, ser interrumpida sin motivo, no realizar la votación según lo establecido en la Ley, etc.

${ }^{414}$ Los motivos eran: si se castiga un delito que no lo sea por su naturaleza; cuando se absuelve a un procesado cuya culpabilidad haya sido declarada mediante el veredicto del jurado o viceversa, que se haya condenado a una persona declarada no culpable; o si no se impone la pena correspondiente a los delitos declarados en el veredicto. 
resoluciones de los Tribunales de derecho; o por quebrantamiento de forma $^{415}$.

El 30 de diciembre de 1872, se publica una circular ${ }^{416}$ del Ministerio de Gracia y Justicia, para adoptar, de manera inmediata, las disposiciones oportunas para el planteamiento de la nueva ley, muy particularmente en la parte referente al Jurado. Se refiere a la institución como la novedad más importante que se introduce en los procedimientos y afirma que su éxito dependerá del planteamiento que se haga ${ }^{417}$ e indica, asimismo, que los ciudadanos han de ser conscientes de la importancia de ejercer este cargo obligatorio $^{418}$.

A este proyecto, que culminará en la Ley de Enjuiciamiento Criminal de 1882 , le sucederá lo mismo que a las normas anteriores, dado que en 1875 de nuevo el jurado es derogado y tampoco aparecerá en la Constitución de 1876. En 1883 se vuelve a plantear a través de la propuesta de un proyecto de Ley del Tribunal del Jurado ya de forma específica y no

\footnotetext{
415 Por irregularidades en la práctica de las pruebas; cuando se haya rechazado alguna pregunta por sugestiva, capciosa o impertinente; por desestimar la petición de las partes para que vuelva el veredicto al Jurado o se remita la causa a uno nuevo; si el número de Magistrados o de Jurados es inferior al que exige la Ley; en caso de que algún Magistrado o Jurado hubiera sido previamente recusado; o que la sentencia haya castigado un delito más grave que el que haya sido objeto de la acusación.

${ }^{416}$ Gaceta de Madrid de 30 de diciembre de 1872. [En línea] [Disponible en: https://www.boe.es/datos/pdfs/BOE//1872/365/A01021-01021.pdf].

${ }^{417}$ Dispone que Grande es la misión que van a desempeñar los ciudadanos a quienes corresponda ejercer las funciones de Jueces de hecho; habla sobre las críticas e insiste en la idea de que no es una institución reciente: un pueblo en cuyos antiguos fueros tantas veces se encuentra la idea cardinal del Jurado; que hasta nuestros días lo ha conservado en algunas provincias, (...) no puede ser acusado de que entra escaso de educación a apreciar hechos tan sensibles como son los que forman la atribución del Jurado. Poco impulso se necesita por tanto para que esta institución se realice y se afiance; y los que han de ser Jueces de derecho contribuirán poderosamente a ello con su enseñanza, (...) para resolver desde el primer momento las dificultades que aparezcan.

${ }^{418}$ En él va envuelto uno de los más trascendentales servicios que al país, interesado en la recta administración de justicia, pueden prestarse.
} 
como parte de los procedimientos especiales establecidos, donde ni siquiera hay una mención en los procedimientos por delitos de imprenta en la LECr.

Como hemos expuesto, veníamos de un contexto en el que la mayor parte de la magistratura era contraria a instaurar el jurado, sin embargo, la experiencia de su práctica durante esos años hizo que poco a poco $\mathrm{y}$, a pesar de las dificultades con las que se encontró, tuviera un éxito relativo, por lo que ya existían tanto posiciones a favor, especialmente apoyadas en el derecho comparado, como en contra, teniendo en cuenta que algunos de los partidarios eran de los que habían rechazado el jurado con anterioridad $^{419}$.

Por su parte, los contrarios alegaban los inconvenientes que suponía el hecho de que un Magistrado tuviera que presidir el jurado y abandonar su lugar en la Audiencia, lo que retrasaba los asuntos que allí debían juzgarse (hoy eso no es un impedimento) o la carga que supone para los ciudadanos que tienen que ser jurados, hasta el punto de que algunos preferían ser procesados por negarse a acudir que ejercer dicha función.

La justificación del proyecto de Ley, donde se reitera la mención a las corrientes contrarias a su instauración, se explica con el argumento de que la causa del Jurado ha hecho su camino en España; y aun hemos de confiar en que opiniones conocidamente adversas concurrirán de buena voluntad a un ensayo prudente del juicio popular, ensayo que pondrá en claro, si por acaso fuese menester, la bondad de una institución con la cual no padecen ni se menoscaban los superiores intereses de la justicia y del

\footnotetext{
419 Así lo explicaba el Magistrado Emilio Bravo: "Nuestra campaña en Madrid fue coronada del éxito más completo. El Jurado hizo justicia y no tuvimos sino motivos de aprobación para todos los veredictos. Nunca dejó de afirmar debidamente la culpabilidad de los procesados, ni se escapó a su penetración circunstancia alguna genérica, ya fuese de atenuación o de agravación. Hizo más todavía alguna vez; que fue, castigar un delito que por deficiencia de la instrucción nosotros no hubiéramos podido penar”. Bravo, op. cit., pág. 36.
} 
orden social, antes bien se garantizan y se consolidan por modo muy eficaz ${ }^{420}$. Al igual que en el modelo anglosajón establecido en EE.UU., la ley determina que el tribunal esté formado por doce jurados más dos suplentes $^{421}$.

La lista de delitos competencia del jurado ${ }^{422}$ según esta nueva ley era mucho más amplia que la establecida previamente en la Ley de Enjuiciamiento Criminal y que los delitos de los que conoce actualmente en España:

- Delitos contra la Constitución (de lesa majestad; contra las Cortes y sus individuos y contra el Consejo de Ministros; delitos contra la forma de gobierno).

- Contra el orden público (en concreto rebelión y sedición).

- Falso testimonio.

- Juegos ${ }^{423}$.

- Abusos contra la honestidad ${ }^{424}$.

- Cohecho.

- Parricidio $^{425}$, asesinato y homicidio.

${ }^{420}$ Gaceta de Madrid, de 9 de febrero de 1883. [En línea] [Disponible en:

https://www.boe.es/datos/pdfs/BOE/1883/040/R00292-00304.pdf]. El proyecto fue publicado el 11 de febrero, con el nombre de "Proyecto de Ley para el establecimiento del Tribunal de Jurado en materia criminal".

${ }^{421}$ Su función era la misma que la que deben cumplir los jurados en la actualidad: emitir un veredicto de culpabilidad o inculpabilidad respecto a los hechos objeto de la acusación y la defensa (art. 2), mientras que serán los tres Magistrados quienes se encarguen de calificar el delito, tener en cuenta las circunstancias modificativas de la responsabilidad criminal, agravantes o atenuantes, impondrán la pena y determinarán la responsabilidad civil, (art. 3).

${ }^{422}$ Delitos según el Código Penal de 1870, vigente en esa época.

${ }^{423} \mathrm{El}$ art. 358 del CP de 1870 disponía que Los banqueros y dueños de casas de juego de suerte, envite ó azar serán castigados con las penas de arresto mayor y multa de 250 á 2.500 pesetas (...) Los jugadores que concurrieren á las casas referidas con las de arresto mayor en su grado mínimo y multa de 125 á 1.250 pesetas. Dentro del Título VI "De los juegos y rifas", del Libro II "Delitos y sus penas".

${ }^{424}$ Los sujetos activos de este delito eran funcionarios públicos y alcaides (arts. $394 \mathrm{y}$ 395 CP 1870). 
- Infanticidio ${ }^{426}$ y aborto.

- Lesiones graves.

- Duelo $^{427}$.

- Violación, estupro, corrupción de menores y rapto.

- Detenciones ilegales, sustracción de menores y abandono de niños.

- Robo, hurto y estafa.

- Incendio y otros estragos.

- Delitos definidos y penados en la ley electoral y los cometidos por medio de la imprenta, grabado u otro medio de publicación.

El art. 6 establecía los requisitos para ser jurado ${ }^{428}$. Ya no se hace referencia a ser cabeza de familia y hay un cambio importante, precisamente lo que la Ley de 1995 establece como incompatibilidades,

${ }^{425}$ El parricidio (art. $417 \mathrm{CP}$ ) era un delito especialmente grave que cometían los que mataban a unos parientes concretos: sus ascendientes, descendientes o cónyuges. Era sancionado con la pena de cadena perpetua a muerte. Este delito fue derogado en el Código de 1995, al incluir la circunstancia mixta de parentesco en el art. 23.

${ }^{426}$ El infanticidio era un delito especial que castigaba a la madre o los abuelos maternos que mataban al hijo que no hubiera cumplido tres días, cuando ese asesinato tenía como fin ocultar la deshonra de la madre (art. $424 \mathrm{CP}$ ). La pena era diferente si el sujeto activo era la madre o los abuelos maternos: prisión correccional (seis meses y un día a seis años) para la madre y prisión mayor (seis años y un día a doce años) para los abuelos. También desapareció al aprobarse el Código Penal de 1995.

427 El duelo se contemplaba dentro del Título VIII "Delitos contra las personas", Capítulo IX. El art. 439 CP establecía que La autoridad que tuviere noticia de estarse concertando un duelo procederá á la detención del provocador y á la del retado, si este hubiera aceptado el desafío, y no los pondrá en libertad hasta que den palabra de honor de desistir de su propósito. Asimismo se castigaba matar y provocar lesiones en duelo.

Aún hay ordenamientos jurídicos que siguen regulando este delito, como es el caso del Código Penal de la Nación Argentina (Ley 11.179, de 29 de octubre de 1921), que lo castiga con pena de hasta cuatro años, si produce la muerte del adversario.

${ }^{428}$ Ser español entre veinticinco y setenta años de edad (se podían excusar los mayores de sesenta). Aquí, ya se ha ampliado el margen de edad, que antes requería un mínimo de treinta años y establece un límite superior, algo que no existía ni existe en la ley vigente; saber leer y escribir; estar en pleno ejercicio de los derechos civiles y políticos; $\mathrm{y}$ tener el domicilio en el término municipal respectivo. 
entonces eran requisitos ${ }^{429}$. Se mantienen las incompatibilidades $y$ prohibiciones de la LECr de 1872, aunque se añadía alguna profesión más como incompatible. El procedimiento de elaboración de las listas varió poco y también el resto del proceso era muy similar al anterior.

\subsubsection{La primera Ley del Jurado en España.}

Después de todas estas trabas y discusiones entre partidarios y detractores, fue el 20 de abril de $1888^{430}$ cuando finalmente se aprobó la ley que supone el antecedente más importante de la regulación actual en materia del tribunal del jurado y que entró en vigor el 1 de enero de 1889 y continuará durante un periodo más largo que las disposiciones que la precedieron, a pesar de que el jurado aún no se instauraría de manera definitiva.

Esta norma presentaba varias cuestiones distintas de las actuales, ya que el tribunal estaba compuesto por doce ciudadanos legos -en lugar de nueve, como explicaremos más adelante- y "tres Magistrados o Jueces de derecho", cuando ahora únicamente está el Magistrado-Presidente. La edad mínima para ser jurado aumenta respecto al proyecto anterior y se fija en treinta años y los mayores de sesenta podían excusarse ${ }^{431}$.

\footnotetext{
${ }^{429}$ Se exigía pertenecer a alguna de estas categorías: ser o haber sido Senador, Diputado a Cortes, miembro de Academias estatales, Doctor de cualquier Facultad, profesor de enseñanza superior o secundaria, de Escuelas especiales y de Bellas Artes, abogado, profesor, ingeniero, médico, notario, funcionarios, etc. También se incluía, según el art. $6.7^{\circ}-13^{\circ}$, a los contribuyentes por inmuebles, cultivo o ganadería, dependiendo de la cantidad y del ámbito territorial en el que estuvieran.

${ }^{430}$ Ley de 20 de abril de 1888. [En línea] [Disponible en:

http://www.bibliotecavirtualdeandalucia.es/catalogo/catalogo_imagenes/imagen.cmd?pa th $=1005443 \&$ posicion $=1]$.

431 "El proceso ante el tribunal del jurado: problemas del régimen actual y perspectivas de futuro". [En línea] [Disponible en:

http://biblioteca.unirioja.es/tfe_e/TFE000569.pdf].
} 
La ley permanecerá vigente durante bastantes años, hasta que el jurado de nuevo queda abolido en 1923. Continúa reuniéndose de forma periódica y sigue compuesto por doce jurados y tres magistrados, pero con la novedad de añadir a dos jurados suplentes, para casos de enfermedad o de otra situación análoga. Su función también es la misma, declarar la culpabilidad o inculpabilidad respecto de los hechos que en concepto de delito les atribuya la acusación y los hechos que modifican la responsabilidad penal de manera parcial o absoluta, mientras que los magistrados imponen la pena y determinan la responsabilidad civil.

Los delitos de su competencia seguían siendo muchos ${ }^{432}$, sobre todo si los comparamos con los que se enjuician actualmente a través de este procedimiento, ya que muy pocos de estos delitos seguirán siendo competencia del jurado en la ley del presente ${ }^{433}$.

El art. 9 regulaba los requisitos ${ }^{434}$. Las prohibiciones eran las mismas y se añadía a los socorridos por la Beneficencia pública como pobres de solemnidad. Ya no se exige que sean determinados contribuyentes pero sí

${ }^{432}$ Según el art. 4 de la Ley: traición; contra las Cortes y sus individuos y contra el Consejo de Ministros; contra la forma de gobierno; de los particulares con ocasión del ejercicio de los derechos individuales garantizados por la Constitución; relativos al ejercicio de los cultos; rebelión y sedición; falsificación de firma o estampilla Real, firmas de Ministros, de moneda, billetes, documentos de crédito o documentos privados o públicos; abusos contra la honestidad, cohecho, malversación; asesinato y sus modalidades; lesiones; duelo; delitos contra la libertad sexual; detenciones ilegales; robos; incendios; imprudencias y delitos de imprenta. También juzgaba la tentativa, la proposición, complicidad y los delitos conexos.

${ }^{433}$ Esta relación de delitos "se vio que desbordaba por completo la capacidad del sistema de enjuiciamiento así establecido, llegando a no poder afrontar con garantías la labor encomendada", por lo que más tarde se reducirá para adaptarlos a la realidad social del momento. Narváez Rodríguez, op. cit., pág. 16.

${ }^{434}$ Aumenta la edad mínima a treinta años, sin límite superior, saber leer y escribir, poder ejercer los derechos civiles y políticos, ser cabeza de familia (o tener un título académico o profesional) y vecino del municipio 
excluye a los pobres. Además, el jurado pasó de reunirse cada tres meses a hacerlo con periodicidad cuatrimestral ${ }^{435}$.

Será la última vez que la ley contemplará doce miembros en el jurado popular ${ }^{436}$. Durante el procedimiento judicial, los jurados podían hacer preguntas para clarificar cualquier duda sobre la prueba.

Una novedad de esta ley es que permite que, una vez terminada la práctica de las pruebas, si las partes al reformar las conclusiones por escrito determinan que los hechos calificados no son competencia del tribunal del jurado, el Presidente, antes de conceder la palabra al Ministerio fiscal, preguntará al defensor o los defensores del procesado o los procesados, si optan por el Tribunal del Jurado o por el de derecho. Si el procesado único o todos los procesados conformes optasen por este último, se retirarán en el acto los Jurados, y el juicio continuará sin retroceso ni interrupción ante los Magistrados, con arreglo a la ley de Enjuiciamiento criminal. En los demás casos, continuará y terminará el juicio ante el Tribunal del Jurado. (Art. 65). Y lo mismo ocurría a la inversa, si el proceso se estaba siguiendo ante el "Tribunal de derecho" y en las conclusiones se calificaban los hechos como competencia del jurado, el Presidente preguntaba y en caso de optar el procesado por el jurado, quedará sin efecto lo actuado en el juicio oral, y el proceso se suspenderá para incluirlo en el alarde de los que se han de ver y sentenciar en la subsiguiente reunión del Jurado. Por tanto los

\footnotetext{
${ }^{435}$ Los periodos eran enero-abril, mayo-agosto, septiembre-diciembre. Este cambio es importante por dos razones. Por un lado, que las reuniones sean menos frecuentes hace más fácil para los jurados dedicarse a sus ocupaciones y, por otro, ahora se establece todo el intervalo de los cuatro meses, no la fecha concreta como antes, por lo que no es necesario que se reúnan un día determinado como sí exigía la regulación anterior.

${ }^{436}$ Los dos suplentes debían asistir también a las sesiones, ya que no solo tenían la función de suplir si alguno no se presentaba sino que podía ocurrir cualquier incidencia durante el juicio y que alguno de los suplentes tuviera que emitir el veredicto, por lo que había de estar presente en la práctica de las pruebas y seguir todo el proceso para poder deliberar con conocimiento.
} 
hechos pueden ser calificados de distinta forma y eso cambiaría el procedimiento por el que tengan que ser juzgados.

Continúa vigente, siguiendo el modelo inglés, el resumen de las pruebas y los informes de las partes que debe hacer el Presidente y que en leyes más recientes queda eliminado ${ }^{437}$. Esta ley introdujo la posibilidad de que, una vez finalizado este periodo, si las partes acusadoras solicitaban la absolución y nadie mantenía la acusación, el juez dictaba auto de sobreseimiento libre por falta de acusación (art. 69), posibilidad que también se contemplaba para cualquier tipo de proceso en la Ley de Enjuiciamiento Criminal.

En $1931^{438}$, se restablece el jurado, a través de un Decreto publicado el 28 de abril ${ }^{439}$, con la misma ley de 1888 vigente pero con la inclusión de algunas modificaciones ${ }^{40}$. Este Decreto es el que prescinde del resumen final de conclusiones y prueba de cargo que debía hacer el Presidente según la Ley de 1888 , por no creerlo ya necesario y de esta forma evitar una especie de segunda acusación fiscal que predispusiera al jurado, como se alega en su propia Exposición de Motivos, donde se explica que es un

437 Según el art. 68, el Presidente hará el resumen de las pruebas, sin entrar en su apreciación; el resumen de los informes del Ministerio Fiscal y de los defensores de las partes, así como de lo manifestado por los procesados, presentando los hechos con la mayor precisión y claridad, y absteniéndose cuidadosamente de revelar su propia opinión.

${ }^{438}$ La Constitución de ese año, promulgada el 9 de diciembre, estableció en su art. 103 que El pueblo participará en la Administración de Justicia mediante la institución del Jurado, cuya organización y funcionamiento serán objeto de una ley especial. Regulación ya muy parecida a la de la actual Constitución de 1931. BOE [En línea] [Disponible en: http://www.congreso.es/docu/constituciones/1931/1931_cd.pdf].

${ }^{439}$ Decreto de 28 de abril de 1931. BOE [En línea] [Disponible en: https://www.boe.es/datos/pdfs/BOE//1931/118/A00360-00362.pdf].

${ }^{440}$ Por ejemplo, se eliminan de su competencia algunos delitos como la falsificación porque suele mostrarse el Jurado poco sensible a la gravísima trascendencia que tales delitos tienen contra la facilidad de las transacciones comerciales; la falsedad, por su complejidad dado el carácter técnico y jurídico que no todos los ciudadanos pueden llegar a comprender; o el duelo, con una justificación mucho más práctica y es la tendencia a su desaparición progresiva en la sociedad. 
trámite peligroso que puede influir sobre los miembros del jurado y vulnera los principios de contradicción y de derecho del acusado a la última palabra $^{441}$. Así, su art. 9 dispuso que queda suprimido el resumen de conclusiones y prueba a cargo del Presidente de la Sección de Derecho.

La composición del tribunal ya no será de doce jurados sino que pasa a ser de tres jueces "de Derecho" y ocho jurados más dos suplentes. Establece asimismo la obligación de que al terminar el juicio reciban la correspondiente indemnización ${ }^{442}$. Además limita las recusaciones sin causa a dos por cada parte e introduce la circunstancia de que, si aparece indicio de soborno a algún miembro del jurado, se procederá como delito de cohecho contra corruptores y corrompidos. También posteriormente más delitos se van excluyendo de la competencia del jurado ${ }^{443}$.

Se incluye a las mujeres como parte del jurado, aunque exclusivamente en unos supuestos concretos ${ }^{444}$. Para establecer el jurado dividido en mitad hombres y mitad mujeres en esos delitos, el art. 9 de este Decreto de septiembre, disponía que Las mujeres que reúnan las

\footnotetext{
${ }^{441}$ López Barja de Quiroga, J. (1999). Instituciones de derecho procesal penal. Madrid: Akal Iure.

${ }^{442}$ Por la asistencia y los gastos de viaje, que más tarde se fijará en 15 pesetas por día de juicio y 10 por dietas de desplazamiento. Se justifica porque en otros países donde el jurado funciona con éxito se ha disminuido el número de sus componentes y enumera los beneficios de ese cambio, sin peligro y con ventaja para el funcionamiento de la institución, y ello aligera la carga de la ciudadanía que supone el ejercicio, trayendo dos consecuencias ventajosas: disminuir la resistencia de colaboración ciudadana y facilitar la más decorosa indemnización. (Exposición de Motivos del Decreto de 28 de abril de 1931).

${ }^{443}$ Por Decreto de 24 de septiembre de 1931 dejan de juzgar los robos con fuerza en las cosas, por no presentar la gravedad de los robos con violencia o intimidación en las personas, y los de imprudencia punible, por no ser dolosos y carecer de intencionalidad en su comisión. Decreto de 24 de septiembre de 1931. BOE [En línea] [Disponible en: https://www.boe.es/datos/pdfs/BOE//1931/267/A01970-01977.pdf].

${ }^{444}$ En los delitos de parricidio, asesinato, homicidio o lesiones, de competencia del Jurado, en el que el móvil pasional fuera el amor, los celos, la fidelidad o cualquier otro aspecto de las relaciones sexuales y en que agresores o víctimas fueren de distinto sexo, el Jurado se compondrá por mitad de hombres y de mujeres, procediéndose a sorteos distintos para cada grupo. (Art. 10 del Decreto de 28 de abril de 1931).
} 
condiciones (...) podrán ser Jurados para conocer en los delitos de parricidio, asesinato, homicidio o lesiones de competencia del Jurado en que el móvil pasional fuera el amor, los celos, la fidelidad o cualquier otro aspecto de las relaciones heterosexuales, aunque agresores y víctimas fueren del mismo sexo. (...) el Jurado se compondrá por mitad de hombres y de mujeres, procediéndose a sorteos distintos para la designación de cuatro titulares y un suplente de cada sexo. Por esta razón, también se introducían nuevas causas para excusarse que solo les afectaban a ellas ${ }^{445}$. En este mismo sentido se reformaba el art. 41 de la Ley, dentro de los trámites anteriores al juicio, la Sala, además de determinar si era competencia del Jurado o del Tribunal de Derecho, debía declarar si se trataba de alguno de los delitos en los que tuvieran que intervenir jurados femeninos. Por el mismo motivo se modifican los artículos referentes a la elaboración de las listas y los sorteos en esos casos concretos de jurado mixto.

"El Jurado tuvo en España un significado más político que jurídico durante la mayor parte del siglo XIX, e incluso durante la Segunda República. Su existencia está llena de altibajos y problemas, que se descubren tanto en las posibilidades de su aplicación real, como en la tipología de delitos y causas a que son aplicados los tribunales de jurados, como en los periodos en que el Jurado desaparece durante años, para volver a aparecer sólo teóricamente haciéndose esfuerzos considerables para que funcione con cierta normalidad" ${ }^{, 46}$.

\footnotetext{
${ }^{445}$ La maternidad próxima o reciente, o la lactancia. Además eran incompatibles las mujeres de jueces, magistrados, abogados o procuradores, entre otras profesiones relacionadas con la Administración de Justicia.

${ }^{446}$ López Jiménez, R. (2009). "El jurado como forma de ejercicio democrático", en Nuevas Políticas Públicas: Anuario multidisciplinar para la modernización de las Administraciones Públicas, $\mathrm{n}^{\circ}$ 5, pág. 224.
} 
Más tarde, en $1933^{447}$, se excluirán los siguientes delitos: contra las Cortes y sus individuos y contra el Consejo de Ministros; contra la forma de Gobierno; de rebelión y sedición; asesinato, homicidio, lesiones e incendio cometidos con móviles terroristas; robos cometidos con violencia o intimidación en las personas; y otro tipo de delitos de terrorismo ${ }^{448}$.

En $1934^{449}$ se modifica la composición, siguen siendo ocho jurados y dos suplentes pero en lugar de tres Magistrados, por razones de economía procesal, se deja en un solo Juez de Derecho.

Por último, durante la Guerra Civil ${ }^{450}$, el jurado es suspendido en dos plazos, en el bando nacional en septiembre de 1936 y, en el republicano, se convierten en "tribunales populares" al año siguiente, a cuya competencia se añadieron los delitos militares y los comunes cometidos por militares, la traición y el espionaje. Ya en 1939 se anula hasta su ulterior reaparición en la época actual con la Constitución y la vigente Ley Orgánica de 1995. El jurado se suspende mediante el Decreto de la Junta Nacional de 8 de septiembre de 1936, pero aunque teóricamente su final llega el 1 de abril de 1939, con la terminación de la Guerra Civil, se entiende que la LOTJ no fue abolida ni derogada sino solamente suspendida, por lo que algún sector doctrinal mantiene la opinión de que la Ley de 1888 ha permanecido vigente hasta 1995, es decir, que el jurado nunca fue derogado en

\footnotetext{
${ }^{447}$ Decreto de 6 de agosto de 1933. BOE [En línea] [Disponible en: https://www.boe.es/datos/pdfs/BOE//1933/218/A00890-00890.pdf].

${ }^{448}$ Los regulados en la Ley sobre represión de delitos cometidos por explosivos, de 10 de julio de 1894.

${ }^{449}$ Decreto de 2 de octubre de 1934. BOE [En línea] [Disponible en: https://www.boe.es/datos/pdfs/BOE//1934/275/A00035-00035.pdf].

${ }^{450}$ El 23 de agosto de 1936 se crea en Madrid un Tribunal Especial para juzgar delitos de rebelión, sedición y contra la seguridad exterior del Estado. Lo formaban tres jueces de derecho y catorce de hecho. Gómez Rivero, R. (1997). "El Tribunal del Jurado en Albacete en la II República", en Anuario de historia del derecho español, n 67 , pág. 1534.
} 
España $^{451}$. La primera sentencia de este tipo se dictó el 30 de mayo de 1996 en la Audiencia Provincial de Palencia, que condenó como culpable de homicidio a un hombre que mató a su hermano. El fallo seguía el veredicto de culpabilidad del jurado.

${ }^{451}$ Planchadell Gargallo, op. cit., pág. 141. 


\subsection{La Ley Orgánica 5/1995, de 22 de mayo, del Tribunal del Jurado $^{452}$.}

El proyecto de la LOTJ fue publicado el 20 de mayo de 1994. En las iniciativas legislativas se justificaba la falta de continuidad a la que aludíamos en la explicación histórica ${ }^{453}$.

La base para la elaboración de la Ley Orgánica 5/1995, de 22 de mayo, del Tribunal del Jurado (LOTJ), la encontramos en el art. 125 de la Constitución Española, dentro del título VI (artículos 117-127), dedicado al poder judicial. "El reconocimiento explícito del jurado en el art. 125 supone, además, que la participación ciudadana en la administración de justicia se verificará, únicamente, mediante esta institución. Ello supone, sin duda, que queda restringido esta participación al ámbito penal. No es constitucionalmente admisible, a mi juicio, pues se desecharon las enmiendas dirigidas a tal fin, una general participación de los ciudadanos en la administración de justicia en asuntos no penales" ${ }^{, 454}$.

El mencionado artículo dispone lo siguiente: Los ciudadanos podrán ejercer la acción popular y participar en la Administración de Justicia mediante la institución del Jurado, en la forma y con respecto a aquellos procesos penales que la ley determine, así como en los Tribunales

\footnotetext{
${ }^{452}$ Ley Orgánica 5/1995, de 22 de mayo, del Tribunal del Jurado. Publicada el 23 de mayo de 1995, en vigor a partir del 23 de noviembre de 1995. BOE [en línea] [disponible en http://www.boe.es/buscar/act.php?id=BOE-A-1995-12095].

${ }^{453}$ Una constante en la historia del derecho constitucional español; cada periodo de libertad ha significado la consagración del jurado; así en la Constitución de Cádiz de 1812, y en las de 1837, 1869 y 1931, y por el contrario cada época de retroceso de las libertades públicas ha eliminado o restringido considerablemente ese instrumento de participación ciudadana. Fundamento constitucional en la Exposición de Motivos del Proyecto de Ley Orgánica del Tribunal del Jurado. Página del Congreso [En línea] [Disponible en: http://www.congreso.es/public_oficiales/L5/CONG/BOCG/A/A_064-01.PDF].

${ }^{454}$ Arias Domínguez, Á. (1996-1997), "Exigencias constitucionales del Tribunal del Jurado", en Anuario de la Facultad de Derecho, no 14-15, pág. 221. Universidad de Extremadura.
} 
consuetudinarios y tradicionales. En un principio, este artículo no incluía la referencia expresa al tribunal del jurado, sino que solamente hablaba de la participación de los ciudadanos en la Administración de Justicia. No fue hasta la redacción definitiva cuando se estableció de manera concreta la frase mediante la institución del Jurado y se abrió la puerta a que una futura ley regulara esta materia.

Anteriores Constituciones también han establecido esta posibilidad que necesitaba un desarrollo legislativo posterior, que en este caso llegó tras casi diecisiete años de vigencia de la Constitución, más si tenemos en cuenta que la LOPJ, en su Disposición Adicional 1 $1^{\mathrm{a}} .1^{455}$, refiere que En el plazo de un año, el Gobierno remitirá a las Cortes Generales los proyectos de ley de (...) y del jurado. Recordemos que la LOPJ es de 1985. A este respecto Antonio del Moral critica esa Disposición Adicional, ya que opina que "ese no puede ser jamás el contenido de una disposición normativa. (...) el legislador presente no puede vincular al legislador futuro. (...) Lo lógico era trasladar el contenido de la disposición (...) y dejar sin más las puertas abiertas para que el legislador futuro amplíe o reduzca ese ámbito de competencias" ${ }^{456}$.

También el art. 83 LOPJ $^{457}$, diez años antes de aprobarse la LOTJ, establece que el ámbito territorial para celebrar este tipo de juicios será la Audiencia Provincial y que la composición y competencias que se regularán por ley posterior, se basará en los siguientes principios:

\footnotetext{
${ }^{455}$ Ley Orgánica 6/1985, de 1 de julio, del Poder Judicial. BOE [En línea] [Disponible en: https://www.boe.es/buscar/doc.php?id=BOE-A-1985-12666].

456 Del Moral García, A. (1994). "Anotaciones al Proyecto de Ley Orgánica del Tribunal del Jurado", en Jueces para la democracia, no 22, págs. 65-75.

${ }^{457}$ Además el art. 19.2 LOPJ hace referencia a que los ciudadanos pueden participar en la Administración de Justicia mediante la institución del Jurado en la forma que la Ley determine.
} 
- La función de Jurado será obligatoria y remunerada ${ }^{458}$, lo que implica también el derecho a ser incluido en las listas, así como a asistir al juicio y realizar las acciones propias del cargo, si se es elegido $^{459}$.

- La intervención de los ciudadanos deberá satisfacer su derecho a la participación en la Administración de Justicia, como fija la Constitución.

- La Ley establecerá su jurisdicción y competencia en función de la naturaleza de los delitos y la cuantía de las penas que les corresponda.

Partiendo del mencionado artículo constitucional, la propia Exposición de Motivos de la LOTJ explica que dos derechos fundamentales quedan relacionados: la participación ${ }^{460}$ de los ciudadanos

${ }^{458} \mathrm{El}$ art. 7 LOTJ especifica que la función de jurado tiene la consideración de deber inexcusable de carácter público y personal, a efectos del ordenamiento laboral y funcionarial. El régimen retributivo e indemnizatorio se regula en el Real Decreto 385/1996, de 1 de marzo. La cuantía de la retribución diaria fue actualizada a través de la Resolución de 21 de julio de 2006, que la fija en $67 €$. También se establecen las cantidades por gastos de viaje con vehículo particular, así como por alojamiento y manutención.

${ }^{459}$ Gimeno Sendra lo considera un derecho por la participación de los ciudadanos en los asuntos públicos (art. $23 \mathrm{CE}$ ) y también un deber puesto que es su obligación colaborar con los Tribunales cuando se es requerido, motivo por el que existen sanciones si no se cumple con la función. Gimeno Sendra, V. (1995). "El artículo 125 de la Constitución”. I Jornadas sobre el Jurado. Universidad de Sevilla.

También E. Arnaldo y E. González manifiestan lo siguiente: "La institución del Jurado popular indudablemente se enlaza con el derecho a la participación directa de los ciudadanos en los asuntos públicos. Estamos, por tanto, ante un derecho subjetivo, perteneciente a la esfera del status activae civitatis, que se debe ejercitar directamente. De aquí la necesidad de regular un procedimiento que permita esta forma de participación. Ahora bien, según la redacción de nuestra Constitución, el Jurado popular se limita a los procesos penales, es decir, no podrá establecerse un Jurado popular en procesos civiles ni en los de ningún otro tipo". Arnaldo Cubilla y González Hernández, op. cit.

460 Gómez Colomer y González Cussac entienden la participación en sentido restringido, es decir, que "su extensión comprenderá exclusivamente las funciones que la LOTJ encomienda a los Jueces legos y ni una más. Básicamente, emitir el veredicto (...). Ello excluye automáticamente su equiparación exacta y completa con los miembros del Poder Judicial técnicos o de carrera en lo que afecta a la organización del 
en los asuntos públicos ${ }^{461}$ y el derecho al juez ordinario predeterminado por la ley ${ }^{462}$, es decir, una modalidad del derecho subjetivo a participar de manera directa en los asuntos públicos, a través de su intervención en el jurado pero a su vez compatible con el ejercicio de la potestad jurisdiccional por parte de jueces y magistrados. Es, por tanto, un derecho de participación de los ciudadanos en la Administración de Justicia y no se considera un derecho del acusado a ser juzgado por sus conciudadanos, a diferencia de lo que hemos visto en el sistema de Estados Unidos ${ }^{463}$.

La Exposición también señala que el motivo para seleccionar determinados delitos que son competencia del jurado y no otros, radica en que no tengan excesiva complejidad, puesto que son los ciudadanos legos los que van a tener que atender a las pruebas que se practiquen en el juicio y decidir sobre los hechos y la culpabilidad o no culpabilidad de los acusados para emitir un veredicto. Por lo tanto, juicios con grandes sumarios, muchos implicados -como algunas de las tramas de corrupción que se enjuician en la actualidad- son de difícil comprensión y seguimiento por la cantidad de datos y la naturaleza del hecho, algo que no ocurre en el caso del homicidio y el asesinato. Sin embargo, hay otros delitos como la malversación, que sí pueden presentar cierta dificultad y que sorprendentemente sí se engloban dentro de la competencia del jurado.

ejercicio de la función jurisdiccional", en Montero Aroca y Gómez Colomer, op. cit., pág. 187.

${ }^{461}$ Art. 23.1 CE: Los ciudadanos tienen el derecho a participar en los asuntos públicos, directamente o por medio de representantes, libremente elegidos en elecciones periódicas por sufragio universal.

${ }^{462}$ Art. 24.2 CE: Todos tienen derecho al Juez ordinario predeterminado por la ley, a la defensa y a la asistencia de letrado, a ser informados de la acusación formulada contra ellos, a un proceso público sin dilaciones indebidas y con todas las garantías, a utilizar los medios de prueba pertinentes para su defensa, a no declarar contra sí mismos, a no confesarse culpables y a la presunción de inocencia.

463 Vilata Menadas, S. (2001). "El Tribunal del Jurado y los deberes positivos generales”, en Boletín del Ministerio de Justicia, Año 55, nº 1892, pág. 1531. 
Para Pérez-Cruz Martín ${ }^{464}$, es aconsejable excluir delitos insignificantes, los que impliquen complejidad social o política (por ejemplo, los de terrorismo) o delitos contables, que requieren apreciaciones técnico-jurídicas complicadas. Y sí se podrían atribuir al jurado los delitos políticos clásicos (contra la seguridad exterior del Estado, la democracia o los derechos fundamentales) y delitos contra funcionarios públicos, para evitar corporativismo.

Determinar si una persona mata a otra o ejerce una acción concreta que lleva a ese resultado de muerte es algo que cualquiera puede observar y pronunciarse sobre ello. Así es como lo explica la LOTJ: La Ley tiene muy en cuenta que el juicio por Jurados constituye expresión plena de los principios básicos procesales de inmediación, prueba formada con fundamento en la libre convicción, exclusión de pruebas ilegales, publicidad y oralidad. Por ello se han seleccionado aquellos delitos en los que la acción típica carece de excesiva complejidad o en los que los elementos normativos integrantes son especialmente aptos para su valoración por ciudadanos no profesionalizados en la función judicial. De hecho, se menciona la posibilidad de ampliar la lista de delitos de su competencia, en función de cómo se vaya consolidando la institución y de la experiencia y, por esa razón, con la última reforma del Código Penal se excluyeron los incendios forestales de la competencia del jurado popular.

En las sesiones del Congreso, cuando se debatía sobre la ley antes de su aprobación ${ }^{465}$, por ejemplo se propuso la inclusión, entre otros, de más

\footnotetext{
${ }^{464}$ Pérez-Cruz Martín, A., et al. (1996). Comentarios sistemáticos a la Ley del Jurado y a la reforma de la prisión preventiva. Granada: Comares, pág. 31.

${ }^{465}$ Dicho debate tuvo posturas encontradas en numerosos aspectos y las dudas sobre el funcionamiento del jurado se manifestaron, incluso ya con la LOTJ en vigor, en sendos Informes del Consejo General del Poder Judicial y de la Fiscalía General del Estado, presentados tras la proposición de ley aprobada por el Pleno del Congreso el 22 de abril de 1997 con la finalidad de que se valorase la posibilidad de una reforma de la LOTJ. Arnaldo Cubilla y González Hernández, op. cit.
} 
delitos contra la vida, como son el aborto y el genocidio ${ }^{466}$. La razón que se alega es que no son muy numerosos en lo que respecta a los juicios y se consideran poco complejos, además de que la valoración del hecho predomina sobre la valoración del derecho, de manera que los no expertos los pueden asumir. Asimismo se añade que son delitos en los que aparece gran reproche y sensibilidad social, lo que valorará mejor un jurado.

Finalmente, en lugar del enjuiciamiento de los delitos más graves, como hemos visto que ocurre en otros países, tanto del modelo puro como del escabinado, se decidió aplicar el criterio de la prudencia y otorgar al jurado la competencia de unos delitos muy concretos para ir viendo su resultado y ampliar progresivamente la competencia si se considera oportuno.

La Ley vigente se aprobó en el año 1995. Se divide en cinco títulos y distribuye los temas que regula de la siguiente forma:

- Capítulo I: Disposiciones generales.

- Capítulo II: Los jurados.

- Capítulo III: Del procedimiento para las causas ante el Tribunal del Jurado.

- Capítulo IV: Del veredicto.

- Capítulo V: De la sentencia.

${ }^{466}$ Diario de Sesiones del Congreso de los Diputados. Sesión n ${ }^{\circ}$ 47, celebrada el 14 de febrero de 2015. 
4.3.1. Competencia del jurado.

\subsubsection{Competencia objetiva.}

Como hemos dicho, con la base del art. $125 \mathrm{CE}$ y el razonamiento de enjuiciar hechos que no tengan excesiva complejidad, los delitos sobre los que tiene competencia un jurado, según el art. 1.1 de la LOTJ, son los siguientes:

a) Delitos contra las personas.

b) Delitos cometidos por los funcionarios públicos en el ejercicio de sus cargos.

c) Delitos contra el honor.

d) Delitos contra la libertad y la seguridad ${ }^{467}$.

La redacción original de la Ley estableció siete clases de delitos:

- Contra la vida humana (incluía el infanticidio).

- Cometidos por los funcionarios públicos en el ejercicio de sus cargos.

- Contra el honor.

- La omisión del deber de socorro.

- Contra la intimidad y el domicilio.

- Contra la libertad.

- Contra el medio ambiente.

Poco antes de su entrada en vigor (a los seis meses de ser publicada, según su disposición final quinta), sufrió otra modificación, que se publicó

${ }^{467}$ Este cuarto bloque no se incluía en la primera presentación del Proyecto de Ley. Tampoco los delitos contra el medioambiente y en concreto los incendios. 
el 17 de noviembre de 1995, en vigor desde el día siguiente. Los siete bloques de delitos se redujeron a cinco:

- Contra las personas (en lugar de "la vida humana").

- Cometidos por los funcionarios públicos en el ejercicio de sus cargos.

- Contra el honor.

- Contra la libertad y la seguridad.

- Delitos de incendios.

Entre los delitos contra las personas, además del homicidio y el asesinato, abarcaba expresamente el parricidio, el infanticidio y el auxilio y la inducción al suicidio. Los delitos medioambientales pasaron a ser “delitos de incendios forestales" y el resto permaneció igual.

Con la posterior regulación del Código Penal, publicada el 23 de noviembre de 1995, a través de su disposición final segunda, se fijó la redacción definitiva del artículo relativo a la competencia del jurado, con los mismos cinco grupos delictivos pero con la desaparición del infanticidio y el parricidio -derogados como tales por el Código Penal e incluidos ahora dentro del homicidio y del asesinato- y con la exclusión del auxilio y la inducción al suicidio. Ese artículo es el que más tiempo ha permanecido en vigor ${ }^{468}$ hasta la reforma del Código Penal -mediante la ya referenciada LO 1/2015, de 30 de marzo- en $2015^{469}$, cuya disposición final tercera eliminó los delitos de incendios forestales de la competencia del jurado, al entenderse que eran lo suficientemente complejos como para tener que ser enjuiciados por profesionales.

\footnotetext{
${ }^{468}$ Desde el 24 de mayo de 1996, publicada el 24 de noviembre de 1995. BOE [En línea] [Disponible en: http://www.boe.es/buscar/act.php?id=BOE-A-1995-12095].

${ }^{469}$ LO 1/2015, de 30 de marzo, publicada al día siguiente y en vigor desde el 1 de julio del mismo año. BOE [En línea] [Disponible en: http://www.boe.es/buscar/act.php?id=BOE-A-1995-12095]. 
Ya la Exposición de Motivos del Proyecto de Ley señalaba que la intención es que el ámbito competencial se amplíe de manera progresiva y según se vaya consolidando la institución del jurado ${ }^{470}$. Es decir que, como sucedía en la ley de 1888 , la lista de delitos está abierta a que se añadan o se excluyan delitos de la competencia del jurado. Prueba de ello es la mencionada reforma que elimina los incendios forestales. Aun existiendo esta posibilidad, sí se fijan los delitos concretos y así, en el apartado 2 del mismo artículo primero, se enumeran de forma específica los delitos que puede juzgar un jurado ${ }^{471}$ :

- Homicidios (arts. 138 a 140 del CP, por lo tanto incluye también la modalidad de asesinato).

- Amenazas (art. 169.1 CP).

- Omisión del deber de socorro (arts. 195 y 196 CP).

- Allanamiento de morada (arts. 202 y 204 CP).

- Infidelidad en la custodia de documentos (arts. 413 a 415 CP).

- Cohecho (arts. 419 a 426 CP).

- Tráfico de influencias (arts. 428 a 430 CP).

- Malversación de caudales públicos (arts. 432 a 434 CP).

- Fraudes y exacciones ilegales (arts. 436 a 438 CP).

- Negociaciones prohibidas a funcionarios (arts. 439 y $440 \mathrm{CP}$ ).

- Infidelidad en la custodia de presos (art. $471 \mathrm{CP}$ ).

${ }^{470}$ En el Proyecto de Ley se consideraba un "propósito" y en la aprobación definitiva desaparece esa palabra y se afirma con más contundencia: el legislador en el futuro valorará, sin duda, a la vista de la experiencia y de la consolidación social de la institución, la ampliación progresiva de los delitos que han de ser objeto de enjuiciamiento.

${ }^{471}$ Además de la LOTJ, el Acuerdo del Pleno No Jurisdiccional de la Sala Segunda del TS de 9 de marzo de 2017, sobre la Incidencia en el procedimiento de la Ley del Jurado de las nuevas reglas de conexión del art. 17 de la LECRIM, expresa que "De los delitos que se enumeran en el art. 1.2. de la ley reguladora, siempre y sólo conocerá el Tribunal del Jurado". 
Como hemos explicado, también aquí se mencionaba el delito de incendios forestales (arts. 352 a $354 \mathrm{CP}$ ).

Para Pérez-Cruz Martín, se deberían haber incluido los delitos contra la libertad sexual, debido a su "dimensión social y el grado de concienciación pública acerca de dichas agresiones" ${ }^{\text {472 }}$, aunque lo hace desde el argumento de la implantación del modelo escabinado, no del anglosajón.

Centrándonos en el primer apartado, que es el objeto de esta tesis, la competencia sobre los delitos contra las personas, engloba tanto el homicidio (art. $138 \mathrm{CP}$ ) como el asesinato (arts. 139 y $140 \mathrm{CP}$ ) y solo es de su competencia cuando el delito es consumado $^{473}$, no en grado de tentativa ${ }^{474}$, lo que sí se juzgaba conforme a la Ley de 1888 . Únicamente enjuician el tipo básico en ambos casos -homicidio y asesinato-, es decir, la competencia no se extiende a la provocación, conspiración y proposición del art. $141 \mathrm{CP}$, ni a la inducción y cooperación al suicidio y la eutanasia del 143 CP.

El 1.3. LOTJ, excluye expresamente de la competencia del jurado los siguientes supuestos:

- Los delitos cuyo enjuiciamiento venga atribuido a la Audiencia nacional ${ }^{475,476}$ :

472 Pérez-Cruz Martín, op. cit., pág. 40.

473 Art. 5.1. Ley Orgánica del Tribunal del Jurado.

${ }^{474}$ La Circular 3/1995, de la Fiscalía General del Estado explica que la razón para justificar esto es, por una parte, evitar que muchas causas lleguen al Jurado y puedan colapsarlo y, por otra, no dejar en manos de legos la dificultad que conlleva distinguir entre el animus laedendi y el animus necandi. López Simó, en de la Oliva Santos, op. cit., págs. 67-68.

${ }^{475}$ Delitos contra el Rey, Familia Real, altos organismos de la Nación y forma de Gobierno; falsificación de moneda y fabricación de tarjetas de crédito y débito falsas y cheques falsos, cuando se produce en el seno de una organización criminal; defraudaciones con graves repercusiones en la seguridad del tráfico mercantil, en la 
- Delitos cometidos por menores de edad -entre catorce y dieciocho años-, que serán juzgados en base a la Ley Orgánica 5/2000, de 12 de enero, reguladora de la responsabilidad penal de los menores.

- Delitos que se encuadran en leyes especiales ${ }^{477}$.

- Los que son competencia de una jurisdicción especial, como los delitos militares.

\subsubsection{Competencia territorial del jurado.}

Según el art. 1.3 LOTJ, El juicio del Jurado se celebrará sólo en el ámbito de la Audiencia Provincial y, en su caso, de los Tribunales que correspondan por razón del aforamiento del acusado. En todo caso quedan excluidos de la competencia del Jurado, los delitos cuyo enjuiciamiento venga atribuido a la Audiencia Nacional.

También lo establece el art. 14.4 LECr.: en los supuestos de competencia de la Audiencia Provincial, si el delito fuere de los atribuidos al Tribunal de Jurado, el conocimiento y fallo corresponderá a éste. Por lo

economía nacional o perjuicio patrimonial a varias personas afectadas en el territorio de más de una Audiencia; tráfico de drogas, fraudes alimentarios y de sustancias farmacéuticas, por parte de grupos criminales y que produzcan daños en lugares pertenecientes a varias Audiencias; delitos cometidos fuera de España, si según la legislación corresponde su enjuiciamiento a los Tribunales españoles. Art. 65 de la Ley Orgánica 6/1985, de 1 de julio, del Poder Judicial (LOPJ). BOE [En línea] [Disponible en: https://www.boe.es/buscar/act.php?id=BOE-A-1985-12666].

${ }^{476}$ Coincidimos en este aspecto con Francisco López Simó sobre la correcta exclusión de los delitos de terrorismo y narcotráfico de la competencia del jurado, que podrían llevar a emitir veredictos por miedo, como afirma Gimeno Sendra, citado por López Simó, op. cit., págs. 82-83.

${ }^{477}$ Por ejemplo, aunque el cohecho sea competencia del jurado, no lo es el cohecho electoral, regulado en el art. 146.1 de la Ley Orgánica 5/1985, de 19 de junio, del Régimen Electoral General (LOREG) y que cometen quienes por medio de recompensas, dádivas, remuneraciones o promesas de las mismas, soliciten directa o indirectamente el voto de algún elector o le induzcan a la abstención. BOE [En línea] [Disponible en: https://www.boe.es/buscar/act.php?id=BOE-A-1985-11672]. 
tanto, el enjuiciamiento de los delitos indicados en la propia LOTJ serán juzgados por el jurado.

Es decir, que, aunque la mayoría de los juicios por jurado se celebren en la Audiencia Provincial, presididos por su Magistrado-Presidente, cabe la posibilidad de que, excepcionalmente, se celebre en el Tribunal Superior de Justicia -Sala Civil y Penal- o en la Sala $2^{\mathrm{a}}$-de lo Penal- del Tribunal Supremo, para casos de enjuiciamientos a personas con la condición de aforados. El Magistrado-Presidente entonces será un Magistrado perteneciente a dichas salas, respectivamente.

4.3.1.3. Alteración de las normas de competencia por conexidad. Respecto a la conexidad ${ }^{478}$, la ley establece que su competencia se extiende al enjuiciamiento de los delitos conexos y relaciona en qué supuestos se da esta circunstancia $^{479}$.

El TS acordó ${ }^{480}$ que el Tribunal del Jurado "conocerá de las causas que pudieran seguirse por otros delitos cuya competencia no le esté en principio atribuida en los casos en que resulte ineludiblemente impuesta la acumulación pero que sean conexos (...) En los casos de relación funcional entre dos delitos (para perpetrar, facilitar ejecución o procurar impunidad)

\footnotetext{
${ }^{478}$ Esto permite que el jurado pueda enjuiciar el desaparecido robo con homicidio, que "como ya no se regula en el CP de 1995 como una figura compleja, puede permitir su enjuiciamiento conjunto por el TJ”. Gómez Colomer y González Cussac, en Montero Aroca y Gómez Colomer (coords.), op. cit. , pág. 205.

${ }^{479}$ Que dos o más personas reunidas cometan simultáneamente los distintos delitos; que dos o más personas cometan más de un delito en distintos lugares o tiempos, si hubiere precedido concierto para ello; que alguno de los delitos se haya cometido para perpetrar otros, facilitar su ejecución o procurar su impunidad. (Art. 5.2. Ley Orgánica del Tribunal del Jurado).

480 Acuerdo del Pleno No Jurisdiccional de la Sala Segunda del TS de 9 de marzo de 2017, sobre la Incidencia en el procedimiento de la Ley del Jurado de las nuevas reglas de conexión del art. 17 de la LECRIM.
} 
si uno de ellos es competencia del Tribunal del Jurado y otro no, conforme al art. 5.2. de la Ley del Tribunal del Jurado, se estimará que existe conexión conociendo el Tribunal del Jurado de los delitos conexos.

Asimismo la LOTJ dispone que, en ningún caso, podrá enjuiciar por conexión el delito de prevaricación. Siguiendo la regla de enjuiciar delitos cuyos hechos no presenten gran complejidad, "El legislador quiere dejar claro que el jurado nunca va a enjuiciar estos delitos pese a ser conexos a alguno que sea competencia directa del citado tribunal de acuerdo con el art. 1.2 LOTJ, y ello debido a la complejidad de este tipo delictivo" ${ }^{\text {"41 }}$. Sí es de su competencia, en cambio, el delito de homicidio no consumado. En caso de que un mismo hecho pueda constituir dos o más delitos y uno de ellos es competencia del jurado, será competente para juzgar también los demás.

Aquí se plantea también la posibilidad de que se dé esa conexidad pero el delito que se considere como principal no sea competencia del jurado. Cuando no se aprecie alguno de los criterios de conexidad que establece la LOTJ; no sea un caso de concurso ideal o de unidad de acción que provoque varios resultados punibles; o, siempre que uno de los delitos sea el de prevaricación, y no pueda enjuiciarse de manera separada sin romper la continencia de la causa, la competencia será del Juzgado de lo Penal de la Audiencia Provincial ${ }^{482}$.

Así lo establece la jurisprudencia, por ejemplo en un asunto en el que se enjuiciaban numerosos delitos: lesiones, tentativa de homicidio, tenencia ilícita de armas, encubrimiento y homicidio consumado, "no siendo el objetivo principal perpetrar el delito contra la vida". Por lo tanto, el

481 González Pillado, E. (2000). Instrucción y preparación del juicio oral en el procedimiento ante el tribunal del jurado. Granada: Comares, pág. 59.

${ }^{482}$ Muerza Esparza, J. J. (2010). "Sobre la competencia del tribunal del jurado por conexión”, en Actualidad jurídica Aranzadi, 798, pág. 19. 
Supremo concluye que "dada la conexidad existente no es posible el enjuiciamiento por separado de los delitos competencia del Jurado y los que no lo son, y si bien el homicidio consumado es el delito más grave de todos los enjuiciados, al no constituir el objetivo principalmente perseguido por los procesados, la competencia corresponde a la Audiencia Provincial" 483 .

\subsubsection{Composición del Tribunal del Jurado.}

El jurado está compuesto por nueve ciudadanos ${ }^{484}$ más dos suplentes número que difiere de los doce establecidos en el siglo XIX que después pasaron a ser ocho-, lo que evita los empates (es importante un número impar, ya que no se sigue el criterio de la unanimidad en el veredicto), y un Magistrado de la Audiencia Provincial, que es quien preside y se encarga, entre otras funciones, de asesorar y orientar a los miembros del jurado, así como resolver las dudas que tengan. Él será quien dicte la sentencia e imponga la correspondiente pena o medida de seguridad, además de resolver sobre la responsabilidad civil derivada del delito. Por su parte, las nueve personas elegidas se encargan de emitir un veredicto en el que se declare probado o no probado el hecho que se esté juzgando, así como la culpabilidad o inculpabilidad de cada acusado inmerso en el proceso. No hay una explicación concreta sobre el motivo para que sea nueve el número de jurados. "Es una decisión original, primero ministerial y después parlamentaria, sin duda motivada para zanjar polémicas que pueden ser absolutamente infructuosas, pero que tiene el mismo fundamento que si se

\footnotetext{
${ }^{483}$ FD $1^{\circ}$ de la STS 2743/2017, de 6 de julio.

${ }^{484}$ El art. 4 del Proyecto de Ley estableció el número de siete jurados y dos suplentes y finalmente se estableció en los nueve más dos suplentes, lo que entró en vigor en el texto definitivo.
} 
hubiera optado por dos, tres, cinco, siete o doce" ${ }^{\text {485 }}$. Puede ser por la influencia francesa, ya que allí son nueve, pero extraña, dado que se optó por el sistema puro y tradicionalmente en España el número ha sido de doce.

Las funciones entre los jurados legos y los jueces profesionales están claramente delimitadas y separadas. El jurado emite el veredicto basándose únicamente en cuestiones de hecho y los magistrados se encargan de las cuestiones jurídicas, dictan las sentencias e imponen las condenas con su correspondiente pena.

Como dispone la propia LOTJ: Los jurados emitirán veredicto declarando probado o no probado el hecho justiciable que el MagistradoPresidente haya determinado como tal, así como aquellos otros hechos que decidan incluir en su veredicto y no impliquen variación sustancial de aquél ${ }^{486}$. También proclamarán la culpabilidad o inculpabilidad de cada acusado por su participación en el hecho o hechos delictivos respecto de los cuales el Magistrado-Presidente hubiese admitido acusación ${ }^{487}$.

Mientras que sobre las funciones del Magistrado-Presidente indica que: dictará sentencia en la que recogerá el veredicto del Jurado e impondrá, en su caso, la pena y medida de seguridad que corresponda. También resolverá, en su caso, sobre la responsabilidad civil del penado o terceros respecto de los cuales se hubiera efectuado reclamación.

Esta diferenciación es muy importante, ya que lo fundamental en el tribunal del jurado es el hecho de que sus miembros nunca van a poder imponer una condena, sino que su labor se limita a emitir un veredicto, lo

\footnotetext{
${ }^{485}$ Gómez Colomer y González Cussac, en Montero Aroca y Gómez Colomer (coords.), op. cit., pág. 280.

${ }^{486}$ Art. 3.1. Ley Orgánica del Tribunal del Jurado.

${ }^{487}$ Art. 3.2. Ley Orgánica del Tribunal del Jurado.
} 
que significa que únicamente determinan la culpabilidad o no culpabilidad de la persona juzgada, mientras que la condena sí la van a establecer jueces profesionales y serán únicamente ellos quienes impongan la pena con la que se castigue al condenado y su duración.

Hay que tener en cuenta que gran parte de las críticas de los detractores de esta institución se sustentan en que el jurado lo componen personas que desconocen las leyes. Sin embargo, esa es precisamente la razón por la que no imponen la condena, dado que esa parte es función del profesional del Derecho, quien conoce las leyes, las penas, su interpretación y su aplicación. El jurado solamente se pronuncia sobre el veredicto tras estar presente durante las sesiones del juicio y poder estudiar los hechos a través de la práctica de las pruebas y el acceso a la documentación. Con todas esas condiciones cualquier persona está capacitada -salvo las excepciones que prevé la propia ley- para determinar si los hechos están probados o no y para concluir si la persona enjuiciada es o no culpable del delito por el que se le está acusando. Más tarde los profesionales dictan la sentencia, absolutoria o condenatoria, siguiendo el criterio del veredicto, e imponen la pena, en su caso. Son ellos también quienes establecen las calificaciones jurídicas (homicidio o asesinato, robo o hurto, agresión o abuso sexual, etc.), las circunstancias modificativas de la responsabilidad criminal, las distintas penas y las responsabilidades civiles, no el jurado. 


\subsubsection{Quiénes pueden ser jurado en España.}

Los requisitos para ejercer este derecho-deber ${ }^{488}$, como la propia ley lo denomina, los establece el art. 8 LOTJ:

- Ser español ${ }^{489}$ mayor de edad ${ }^{490}$.

- Gozar del pleno ejercicio de los derechos civiles y políticos.

- Saber leer y escribir ${ }^{491}$.

- Ser vecino de cualquiera de los municipios de la provincia en que el delito se hubiera cometido.

- Tener aptitud suficiente para el desempeño de la función de jurado.

Este último apartado es una novedad, ya que hasta principios de 2018 existía una limitación, estar afectado por discapacidad física o psíquica que impida el desempeño de la función de jurado. El 14 de febrero de 2018 entró en vigor una reforma que, entre otros, afecta al art. 8, cuyo último requisito consiste en Contar con la aptitud suficiente para el desempeño de

\footnotetext{
${ }^{488}$ Esta doble naturaleza se explica en tanto que el derecho a ser jurado, aunque no sea un derecho fundamental ni constitucional, "se traduce en la facultad de alcanzar la cualidad de miembro titular o suplente lego de un Tribunal del Jurado, siempre que no concurra motivo que lo impida"; y por su parte, el deber implica que el ciudadano debe desempeñar las funciones establecidas por la Ley, salvo que incurra en alguna de las causas que lo imposibilitan, ya que si no, incurrirá en infracciones que conllevan la correspondiente sanción. Gómez Colomer y González Cussac, en Montero Aroca y Gómez Colomer (coords.), op. cit., pág. 393.

${ }^{489}$ La explicación para que sean solamente españoles y se excluya la posibilidad, por ejemplo, de extranjeros que lleven un tiempo residiendo en España, se puede justificar con que "todo hombre tiene derecho a ser juzgado por aquellos que se hallan inmersos en el mismo ámbito de valores, en la misma apreciación de lo justo de las acciones (...) éstos -los valores- no desaparecen por el hecho de que el extranjero se nacionalice y en ese caso ya podría ser jurado y efectivamente esto es así, pero la nacionalización es un indicio de plena integración y además el legislador no puede prever el caso concreto". Gutiérrez Sanz, Ma R. (1996). "El estatuto jurídico del ciudadano jurado desde la perspectiva de la Ley Orgánica del Tribunal del Jurado", en Anuario jurídico de La Rioja $\mathrm{n}^{\circ} 2$, pág. 357.

${ }^{490}$ En consonancia con la mayoría de edad establecida en el art. 12 de la CE y que rebaja la edad de treinta exigida en 1888 .

${ }^{491}$ En el Proyecto de Ley se requería tener el graduado escolar o formación equivalente.
} 
la función de jurado. Las personas con discapacidad no podrán ser excluidas por esta circunstancia de la función de jurado, debiéndoseles proporcionar por parte de la Administración de Justicia los apoyos precisos, así como efectuar los ajustes razonables, para que puedan desempeñar con normalidad este cometido.

En realidad es una reforma compleja, justificada por la Convención Internacional sobre los Derechos de las Personas con Discapacidad, vigente en España desde el 3 de mayo de 2008. Es cierto, como se afirma en el Preámbulo de la reforma ${ }^{492}$, que la regulación anterior carece de matices que den el apoyo necesario que la sociedad debe prestar a las personas con discapacidad "para garantizar su efectiva y plena participación en la vida civil”. Aunque la actual tampoco especifica mucho más con el requisito "aptitud suficiente", limitándose a dejar claro que las personas con discapacidad no pueden ser excluidas y que la Administración de Justicia deberá realizar los ajustes necesarios, lo cual es razonable si tenemos en cuenta que hay muy diferentes tipos de discapacidades y que no todas afectan de la misma forma para el desempeño de esta función. MartínezPujalte interpreta que dicha "aptitud suficiente" se refiere a saber leer y escribir y que, por tanto, "no podrá exigirse a las personas con discapacidad ningún requisito adicional de aptitud que el que se exige a todas las demás personas, por lo que todas las personas con discapacidad que sepan leer y escribir (...) podrán ser jurados, siempre que no concurra en ellas, naturalmente, ninguna otra causa de exclusión"493.

\footnotetext{
492 LO 1/2017, de 13 de diciembre, de modificación de la Ley Orgánica 5/1995, de 22 de mayo, del Tribunal del Jurado, para garantizar la participación de las personas con discapacidad sin exclusiones, que ha entrado en vigor el 14 de febrero de 2018. BOE [En línea] [Disponible en: https://www.boe.es/boe/dias/2017/12/14/pdfs/BOE-A-201714689.pdf].

${ }^{493}$ Martínez-Pujalte, A. L. (2018). "La participación de las personas con discapacidad en la institución del Jurado", en Revista de derecho político, nº 103, pág. 341.
} 
Como vemos, prácticamente cualquier persona mayor de edad puede ser llamada a ser jurado, sin embargo, existen unas incapacidades, como los condenados por delito doloso no rehabilitados; procesados, acusados, detenidos; y los suspendidos de su empleo o cargo público por un procedimiento penal. Asimismo lo tienen prohibido quienes formen parte en la causa, sean acusadores, defensas, testigos, peritos, etc., o tengan algún tipo de relación con cualquiera de los intervinientes o interés, directo o indirecto, en el proceso.

También hay incompatibilidades lógicas por el cargo, como el Rey, la Familia Real, Diputados, Senadores, Ministros, Presidentes del Gobierno o de las Comunidades Autónomas, Delegados del Gobierno, el Defensor del Pueblo, miembros del Tribunal Constitucional o del Consejo General del Poder Judicial, etc., a semejanza de la norma antigua. Además, como lo que se busca es precisamente que los ciudadanos jurados sean legos en derecho, también se excluye a personas que tengan conocimientos jurídicos ${ }^{494}$, por ejemplo, abogados, procuradores, profesores universitarios de disciplinas jurídicas o de Medicina Legal, jueces, fiscales, funcionarios de la Administración de Justicia, los Cuerpos y Fuerzas de Seguridad del Estado o Instituciones Penitenciarias, etc.

Y por último la ley regula unas excusas para que quien se encuentre en esos supuestos si quiere pueda ser jurado pero si no, pueda rechazarlo, como ser mayor de sesenta y cinco años ${ }^{495}$ o discapacitado ${ }^{496}$, haber sido

\footnotetext{
494 Sin embargo, aunque ese parece ser el denominador común de todas estas profesiones, no queda claro el criterio de exclusión de quien tiene conocimientos jurídicos pero no está en activo, por ejemplo un licenciado en Derecho o más aun, que expresamente no se incluya a los notarios o registradores de la propiedad. Bachmaier Winter, L., en de la Oliva Santos, op. cit., pág. 178.

${ }^{495}$ El Proyecto de Ley inicial se refería a quienes tuvieran o superaran la edad de jubilación establecida para Jueces o Magistrados.

496 También introducido por la LO 1/2017, de 13 de febrero, en virtud de la modificación del art. 12.1 LOTJ.
} 
jurado en los cuatro años anteriores, grave trastorno por causas familiares, tener un trabajo de interés general en el que no pueda ser sustituido, residir en el extranjero, militares por razones de servicio o cualquier otra causa suficiente que dificulte el ejercicio de la función de jurado de forma grave. Todos estos motivos, lógicamente han de ser debidamente acreditados ${ }^{497}$.

El proceso de elección y composición de los miembros del jurado se regula en los arts. 13 a 23 de la LOTJ y consta de dos fases. En primer lugar, hay que sortear ${ }^{498}$ a los candidatos para todas las causas que se vayan a enjuiciar a lo largo de los dos siguientes años y posteriormente habrá que elegir el jurado concreto que actuará en cada caso ${ }^{499}$.

\subsubsection{Incoación, instrucción y fase del juicio oral.}

Será el Juez de Instrucción ${ }^{500}$ quien, cuando resulte contra persona determinada la imputación de un delito cuyo enjuiciamiento esté atribuido

${ }^{497}$ La LOTJ no incluye de manera expresa la objeción de conciencia como causa de excusa, puesto que presenta el inconveniente "de ser un cajón desastre en el que podrían basarse una importante cantidad de renuncias a formar parte del Tribunal". Villanueva Turnes, A. (2016). "La objeción de conciencia y el Tribunal del Jurado en España", en Inciso, Vol. 18, nº 2, pág. 43.

${ }^{498}$ El Real Decreto 1398/1995, de 4 de agosto, regula el sorteo para la formación de las listas de candidatos a jurados, modificado un año más tarde mediante el Real Decreto 2067/1996, de 13 de septiembre, en la parte que afecta a la fórmula que se utiliza para realizar el sorteo y así evitar que algunos electores, aunque fuera un número mínimo, quedaran fuera del sorteo.

${ }^{499}$ La primera fase tiene lugar desde de septiembre hasta noviembre y la segunda cada vez que sea necesario constituir un tribunal popular. En la primera etapa, se selecciona a los candidatos mediante un sorteo público, de entre todas las personas inscritas en el censo electoral, cada dos años, según la previsión de los asuntos que se estime. En la segunda, se efectúa un nuevo sorteo, para cada caso y se obtienen treinta y seis candidatos, que deben exponer cualquier causa de exclusión, incompatibilidad, etc. También si presentan alguna discapacidad relevante para el ejercicio de su función, según la tercera y última modificación efectuada por la LO 1/2017, de 13 de diciembre. En esos casos deben hacer constar cuál es la situación personal y solicitar los medios de apoyo y ajustes que precisen para ejercer correctamente dicha función.

500 Julio Muerza, Catedrático de Derecho Procesal de la Universidad de Zaragoza, dice que "Una cuestión que se ha planteado la doctrina es si el Juez de Instrucción debe 
al Tribunal del Jurado, dicte la resolución para incoar el procedimiento ${ }^{501}$.

Se citará a las partes y al Ministerio Fiscal a una comparecencia, para concretar la imputación o para que el investigado inste el sobreseimiento.

Si el Juez de Instrucción acuerda continuar con el procedimiento, se practicarán las diligencias correspondientes e instará a las partes para que realicen el escrito de calificación ${ }^{502}$, que se trasladará al acusado para que también formule el escrito correspondiente. El Juez señalará el día más próximo posible para celebrar la audiencia preliminar de las partes sobre la procedencia de abrir o no el juicio oral, en la que se practicarán las diligencias propuestas por las partes e incluso proponer alguna para practicar en el acto. El Juez decide, mediante auto, si se abre el juicio oral $^{503}$ o no y, en este último caso, acuerda el sobreseimiento, que se podrá recurrir en apelación ante la Audiencia Provincial.

$\mathrm{Si}$, en cambio, considera que el delito no es de los atribuidos a la competencia del Tribunal del Jurado, incoará el procedimiento que corresponda $^{504}$. Este cambio de procedimiento también podrán solicitarlo

notificar la incoación del procedimiento al Presidente de la Audiencia Provincial, manifestando que aunque la Ley no establezca nada, y dado que las normas de la LECr son supletorias, deberá realizarla". Muerza Esparza, J. J. (1996). “Ámbito de aplicación, competencia y procedimiento para las causas ante el tribunal del jurado", en Anuario jurídico de La Rioja, $\mathrm{n}^{\circ}$ 2, pág. 379.

${ }^{501}$ Normalmente se incoan diligencias previas, según indica el art. 760 de la LECr, y posteriormente se transforma el procedimiento, al amparo del art. 309 bis de la LECr.

${ }^{502}$ En todo lo que no sea específico del tribunal del jurado, regirán las normas de la LECr. Este escrito figura en el art. 650 y debe contener: el hecho punible, su calificación legal, la participación de los procesados, las circunstancias modificativas de la responsabilidad criminal, las penas y, respecto a la acción civil, la cantidad correspondiente y las personas responsables.

${ }^{503} \mathrm{El}$ auto que declare la apertura debe contener: los hechos que se vayan a enjuiciar, los acusados y los terceros civiles responsables, la fundamentación de la procedencia de la apertura del juicio, el órgano competente para juzgarlo y ordenará deducir testimonio de los escritos de calificación, de la documentación de las diligencias que deban ser ratificadas en la fase oral y no se puedan reproducir allí y del auto de apertura.

${ }^{504}$ Por ejemplo, la STS 4521/2016, de 11 de octubre, anula y deja sin efecto por un intento de asesinato "desde el momento de la declaración sobre admisión de la prueba (...) se procederá a reponer las actuaciones a dicho trámite siguiéndose entonces por el 
las partes si, en el escrito de solicitud de juicio oral y calificación, entienden que todos los hechos delictivos objeto de acusación no son de los que su enjuiciamiento corresponde al Jurado. En estos casos, una vez acordada su apertura, se lo remite al Juez de lo Penal correspondiente o a la Audiencia Provincial, según proceda.

Si se ha acordado por el Juez de Instrucción la apertura del juicio oral, en quince días se emplazará a las partes ante el Tribunal competente para el enjuiciamiento. Las partes podrán plantear las siguientes cuestiones previas, que se tramitarán según el procedimiento de la $\mathrm{LECr}^{505}$ :

- Sobre competencia o inadecuación del procedimiento.

- Excepciones de declinatoria de jurisdicción ${ }^{506}$, cosa juzgada, prescripción, amnistía, indulto o falta de autorización administrativa cuando sea necesaria.

- Vulneración de un derecho fundamental.

- Solicitud de ampliación a algún hecho no admitido en la instrucción o exclusión si no estaba en los escritos de acusación. Frente a estas cuestiones previas cabe interponer recurso de apelación del art. 846 bis a) de la LECr., debido a que su estimación no impide la continuación del proceso sino

cauce del sumario ordinario a enjuiciar por la Audiencia Provincial con tres Magistrados y exclusión del Jurado, debiendo el nuevo Tribunal resolver sobre (...) (los) demás medios de prueba propuestos en relación con la imputación del acusado por ese asesinato intentado". En su FD $2^{\circ}$ determina que "No es preciso retrotraer más allá la tramitación. En concreto la funcionalidad del procesamiento se satisface sobradamente por las resoluciones de igual cometido por el procedimiento del Jurado que aquí fue seguido".

${ }_{505}$ Artículos de previo pronunciamiento, arts. 668 a 677 de la LECr.

506 "Bajo esta expresión la doctrina mayoritaria viene comprendiendo, la falta de jurisdicción, y la falta de competencia tanto objetiva, funcional, como territorial". Muerza Esparza (1996), op. cit., pág. 386. 
que delimitan el objeto del procedimiento o la prueba que debe practicarse en el juicio $^{507}$.

- Impugnación de medios de prueba y proposición de nuevos ${ }^{508}$.

Posteriormente, el Magistrado-Presidente dictará auto de hechos justiciables, con el contenido establecido en la ley ${ }^{509}$.

Y, por último, se lleva a cabo la constitución del tribunal. La Exposición de Motivos de la Ley explica que no es un órgano de carácter permanente y se cambia la manera de establecer las causas respecto a la regulación de la Ley de $1888^{510}$.

Para constituirlo han de concurrir al menos veinte se $^{511}$ los candidatos, de lo contrario se hará un nuevo señalamiento dentro de los quince días siguientes, donde se sortearán hasta ocho candidatos complementarios, lo que se repetirá, si tampoco se consigue, hasta que se

${ }^{507}$ De Diego Díez, L. A. (2002). Recursos interlocutorios en las causas ante el Tribunal del Jurado. Barcelona: Bosch, pág. 119.

508 "Para un sector de la doctrina es éste y no el escrito de calificaciones el primer momento procesal para la proposición de pruebas, dado que los anteriores en que la Ley alude a las pruebas deben entenderse que van dirigidos al Auto de apertura del juicio oral”. Muerza Esparza (1996), op. cit., pág. 387. Sin embargo él cree que no es así, al referirse la LOTJ en el art. 29 al escrito de calificaciones, ya que se remite al $650 \mathrm{LECr}$ -el contenido de dicho escrito en el proceso ordinario- y concluye que las partes pueden en ese momento proponer los medios de prueba. Asimismo manifiesta que es la misma postura que comparte la Fiscalía General del Estado.

${ }^{509}$ El contenido de dicho auto es el siguiente: los hechos justiciables alegados tanto por la acusación como por la defensa, expresados en párrafos separados y numerados; los hechos que configuran el grado de ejecución del delito, el de participación del acusado y las circunstancias modificativas de la responsabilidad criminal; la procedencia de los medios de prueba propuestos; el señalamiento para la vista del juicio oral.

${ }^{510}$ Ya no es necesario fijar unos días concretos ni que se reunieran con periodicidad trimestral ni cuatrimestral, sino que el jurado se conforma para cada causa y así no recae en los mismos toda la carga de juzgar todos los casos de un mismo periodo, de forma que se reparte entre más personas.

${ }^{511}$ El hecho de que sean veinte es porque si finalmente el tribunal lo componen once miembros (nueve jurados más dos suplentes) y la acusación y la defensa disponen cada uno de cuatro recusaciones, ocho en total, debe haber diecinueve candidatos y el legislador añade uno para que exista un margen mínimo. Begué Lezaun, J. J. (2010). El proceso ante el Tribunal del Jurado. Barcelona: Bosch, pág. 277. 
obtenga el número suficiente. En ese momento también pueden ser recusados o expresar ellos mismos cualquier causa de exclusión o incapacidad. La no comparecencia injustificada conlleva pena de multa ${ }^{512}$.

En el caso de que sí comparezca el número requerido, se llevará a cabo el sorteo de los nueve jurados definitivos y los dos suplentes que enjuiciarán la causa correspondiente. Una vez más, se podrán recusar hasta cuatro personas por parte de las acusaciones y otras cuatro por las defensas, todos ellos sin necesidad de alegar un motivo, lo que garantiza mayor imparcialidad de los jurados ${ }^{513}$.

Constituido el tribunal del jurado en esta forma $y$, tras extender el acta de dicho procedimiento, los jurados declararán el juramento o promesa con la fórmula que les dirá el Magistrado-Presidente ${ }^{514}$. Negarse a prestar el juramento supone pena de multa ${ }^{515}$ que se impondrá en el acto. Si persiste, se nombrará al suplente. Una vez lo hayan declarado todos, dará comienzo el juicio en audiencia pública, salvo que, como contempla la LOTJ en su

\footnotetext{
512 El art. 39.2 LOTJ sanciona con 25000 pesetas (150€) no comparecer a la primera citación y entre $100000(600 €)$ y 250000 pesetas $(1500 €)$ la falta de asistencia a la segunda.

513 Así lo afirman tanto la Exposición de Motivos de la LOTJ como la jurisprudencia, por ejemplo, en la STS 7876/2005, de 21 de diciembre, en su FD $3^{\circ}$, que desestima uno de los motivos de la casación fundamentado en la indefensión que sufrió la parte recurrente al no haber podido recusar a uno de los candidatos. La Sala entiende que "Siendo la situación de indefensión real y objetiva el elemento fundamental que fundamentaría, en su caso, la estimación del motivo, es sorprendente que ninguna clase de alegación se realiza por el recurrente para justificar la existencia de un menoscabo efectivo y verificable del derecho de la parte. (...) no se alega por las Acusaciones Particulares ni siquiera la puesta en peligro de la imparcialidad y la proporcionalidad del jurado". Esta posibilidad no se extiende ni a los actores civiles ni a los terceros responsables civiles que sí deben alegar alguna causa para poder solicitar la recusación. 514 Art. 41.1 LOTJ: “¿Juran o prometen desempeñar bien y fielmente la función del jurado, con imparcialidad, sin odio ni afecto, examinando la acusación, apreciando las pruebas y resolviendo si son culpables o no culpables de los delitos objeto del procedimiento los acusados..., así como guardar secreto de las deliberaciones?". De uno en uno se acercarán al Magistrado-Presidente y dirán "sí juro" o "sí prometo".

${ }^{515}$ De 50000 pesetas (300 €), según el art. 41.4 LOTJ.
} 
art. 43, proceda su celebración a puerta cerrada ${ }^{516}$, lo que decidirá el Magistrado-Presidente, tras oír a las partes y consultar al jurado.

A partir de ese momento, salvo lo específicamente regulado en la LOTJ, el juicio se desarrolla siguiendo los trámites ordinarios ${ }^{517}$ regulados en la Ley de Enjuiciamiento Criminal ${ }^{518}$. Es obligatoria la asistencia del acusado y de su abogado, que deberá estar a disposición del Tribunal del Jurado, ya que este juicio oral tiene prioridad frente a cualquier otro señalamiento o actuación procesal de cualquier orden jurisdiccional.

Durante la práctica de la prueba en el juicio oral ${ }^{519}$, los jurados pueden dirigir preguntas por escrito, tanto a los acusados, como a los testigos y peritos. La prueba documental será analizada directamente por ellos y se constituirán en el lugar del suceso para practicar la prueba de inspección ocular.

\footnotetext{
${ }^{516}$ Los motivos se describen en el art. 681 LECr, por razones de seguridad $u$ orden público, o la adecuada protección de los derechos fundamentales de los intervinientes, en particular, el derecho a la intimidad de la víctima, el respeto debido a la misma o a su familia, o resulte necesario para evitar a las víctimas perjuicios relevantes que, de otro modo, podrían derivar del desarrollo ordinario del proceso.

${ }^{517}$ Al no precisar la LOTJ si se deben aplicar los trámites del procedimiento ordinario o del abreviado, se entiende que se refiere al ordinario porque es el general previsto en la LECr, salvo remisión específica al abreviado. Seoane Spiegelberg, J.L. (1998). "Incoación e investigación en el procedimiento ante el tribunal del jurado", en Anuario da Facultade de Dereito da Universidade da Coruña, $\mathrm{n}^{\circ}$ 2, pág. 519.

${ }^{518}$ Arts. 680 y ss. LECr. "De la celebración del juicio oral", Título III, dentro del Libro III "Del juicio oral".

519 Sobre este punto una vez más se asienta el debate acerca de si los jurados están preparados o no para llevar a cabo esta actividad. Los contrarios al jurado manifiestan que personas ajenas al mundo jurídico no pueden apreciar las pruebas, ya que esa acción compete exclusivamente al poder judicial; mientras que los defensores afirman que la apreciación de las pruebas no es una técnica exclusivamente jurídica. Compartimos la opinión de Raquel López Jiménez en el sentido de que dicha dificultad no puede ser un impedimento para negar a los ciudadanos la participación en la Administración de Justicia y porque es cierto que mientras ejercen de jurados ostentan también la potestad jurisidiccional, como así les garantizan la CE y la LOTJ. López Jiménez, R. (2002). La prueba en el juicio por jurados. Valencia: Tirant, pág. 303.
} 
También el Fiscal y los abogados de la acusación y la defensa pueden formular preguntas si aprecian contradicciones entre la prueba practicada en el juicio y en la fase de instrucción, aunque no se leerán esas previas declaraciones de la instrucción ni tendrán valor de prueba, salvo que constituyan una prueba anticipada, pero sí se unen al acta. Este hecho se justifica para garantizar que la única prueba válida que desvirtúe la presunción de inocencia sea la practicada en el juicio y por lo tanto sirva de base para su condena, sin embargo, esto sí puede realizarse en el proceso ordinario, según el art. $714 \mathrm{LECr}^{520}$. Sobre esta especialidad probatoria se pronuncia la jurisprudencia, por ejemplo, en la STS 2940/2016, de 9 de junio $^{521}$. Más recientemente, el Supremo establece que "las declaraciones sumariales, por sí solas, carecen de eficacia probatoria, pero pueden ser valoradas cuando han existido contradicciones y retractaciones entre lo dicho en el juicio oral y lo declarado en la instrucción de la causa por el acusado, testigos o peritos (...) Lo relevante en todo caso es que la

${ }^{520}$ Cuando la declaración del testigo en el juicio oral no sea conforme en lo sustancial con la prestada en el sumario, podrá pedirse la lectura de ésta por cualquiera de las partes. Después de leída, el presidente invitará al testigo a que explique la diferencia o contradicción que entre sus declaraciones observe.

521 "Los jurados no solo conocen lo declarado en el juicio, sino que, primero, a través del interrogatorio y, después, del testimonio incorporado al acta, también acceden a lo manifestado en la fase de instrucción, de manera que no pueden ignorar el contenido de todas las declaraciones prestadas, pudiendo valorar las primeras en relación a las efectuadas en el juicio oral, con las contradicciones que resulten entre ellas y con las explicaciones que sobre las mismas aporten sus autores. (...) El artículo 45.6 impedirá que se tengan como prueba las declaraciones sumariales con carácter general, pero no impide tener en cuenta aquellos casos excepcionales en los que la jurisprudencia ha admitido la posibilidad de valorarlas una vez incorporadas adecuadamente al juicio oral, siempre que se hayan practicado en su momento de forma inobjetable. (...) permite a las partes interrogar a los que prestan declaración sobre las contradicciones entre lo que habían manifestado en el sumario y lo que declaran ante el tribunal del jurado, pero modifica la regla transcrita del art. 714 LECrim, y únicamente permite que las partes se valgan de las anteriores declaraciones sumariales sin que puedan pedir su lectura. Por otro lado, el sumario no está a disposición del Tribunal y no cabe que pueda leerse". 
confrontación entre lo declarado con anterioridad y en el juicio oral sea directa con la presencia personal del interrogado",522.

Tras la fase probatoria, las partes pueden modificar sus conclusiones provisionales y, si en las definitivas se califican los hechos como un delito no atribuido a la competencia del jurado, los jurados siguen conociendo del asunto.

El Magistrado Presidente puede realizar el llamado planteamiento de la tesis, que se regula en el art. $733 \mathrm{LECr}^{523}$. Está directamente relacionado con el principio acusatorio, que implica que un Tribunal, a la hora de dictar sentencia, no puede ir más allá de lo que hayan solicitado las acusaciones, por lo tanto, no puede incluir hechos más graves que los que hayan calificado las acusaciones ni realizar una calificación jurídica más grave que ellas. Con el planteamiento de la tesis, el Tribunal puede, de manera excepcional, sugerir una calificación alternativa, siempre que no produzca indefensión y sea favorable. A este respecto, la jurisprudencia establece que "el órgano judicial, una vez efectuadas las calificaciones definitivas,

${ }^{522}$ FD Segundo.4, de la STS 1784/2019, de 24 de mayo.

${ }^{523}$ Si juzgando por el resultado de las pruebas entendiere el Tribunal que el hecho justiciable ha sido calificado con manifiesto error, podrá el Presidente emplear la siguiente fórmula:

«Sin que sea visto prejuzgar el fallo definitivo sobre las conclusiones de la acusación y la defensa, el Tribunal desea que el Fiscal y los defensores del procesado (o los defensores de las partes cuando fueren varias) le ilustren acerca de si el hecho justiciable constituye el delito de... o si existe la circunstancia eximente de responsabilidad a que se refiere el número... del artículo... del Código Penal.».

Esta facultad excepcional, de que el Tribunal usará con moderación, no se extiende a las causas por delitos que sólo pueden perseguirse a instancia de parte, ni tampoco es aplicable a los errores que hayan podido cometerse en los escritos de calificación, así respecto a la apreciación de las circunstancias atenuantes y agravantes como en cuanto a la participación de cada uno de los procesados en la ejecución del delito público que sea materia del juicio.

Si el Fiscal o cualquiera de los defensores de las partes indicaren que no están suficientemente preparados para discutir la cuestión propuesta por el Presidente, se suspenderá la sesión hasta el siguiente día. 
puede someter a las partes una nueva calificación jurídica, si considera que la efectuada incurre en manifiesto error, ${ }^{, 524}$.

Cabe la suspensión del juicio por cualquiera de los motivos generales de la $\mathrm{LECr}^{525}$. Si esta se prolonga durante cinco o más días, se disolverá el jurado. La LOTJ también contempla casos de disolución anticipada del jurado o por conformidad de las partes ${ }^{526}$, novedad asimismo aportada por la legislación anglosajona, ya que en Estados Unidos existe la posibilidad de disolver el jurado después de la práctica de la prueba, si es insuficiente para mantener la convicción por el delito ${ }^{527}$.

\subsubsection{Emisión del veredicto.}

El veredicto es la gran particularidad en este tipo de procesos. Lo que dictamine el jurado vinculará al juez y la sentencia tendrá que dirigirse en el sentido en el que ellos hayan decidido. Se regula en el Capítulo IV (arts. 52-66) de la LOTJ.

\footnotetext{
${ }^{524}$ FD $15^{\circ}$ de la STS 4088/2016, de 26 de septiembre.

${ }^{525}$ La suspensión del juicio oral se regula en los arts. 744 y ss. LECr. Procede su suspensión si las partes no tienen preparadas las pruebas por motivos independientes a su voluntad; si el Tribunal tiene que decidir alguna cuestión incidental y no puede hacerlo en el acto; si hay que practicar alguna prueba fuera del lugar de las sesiones; cuando no comparezcan testigos cuya declaración se considere necesaria por parte del Tribunal; por enfermedad de alguna de las partes intervinientes, miembros del Tribunal o el Ministerio Fiscal; o por revelaciones inesperadas que alteren el juicio de manera que se requieran nuevas pruebas.

${ }^{526} \mathrm{Si}$ no existe prueba de cargo en la que basar una condena, en cuyo caso lo puede solicitar la defensa o decidirlo de oficio el Magistrado-Presidente y en tres días se dictará sentencia absolutoria; cuando existe conformidad de las partes, con el escrito de calificación que solicite la pena más grave o con el que presenten en el acto suscrito por todas; que el Ministerio Fiscal y las partes acusadoras desistan de la petición de condena, en las conclusiones definitivas o durante cualquier momento anterior. En estos casos también se dictará sentencia absolutoria.

${ }^{527}$ Exposición de Motivos de la LOTJ. 
El objeto del veredicto ${ }^{528}$ está compuesto por el relato de hechos que elabora el Magistrado-Presidente para que el jurado se pronuncie sobre ellos. Siempre se expondrá en párrafos separados y numerados y contiene necesariamente los siguientes puntos:

- Los hechos alegados por las partes que los jurados declaren probados o no, con distinción entre los favorables y los contrarios al acusado, empezando por el hecho principal de la acusación y luego de la defensa.

- Los hechos que determinen una causa de exención de la responsabilidad, por ejemplo una incapacidad psíquica. El jurado se limita a declarar si el hecho que demuestra esa causa se da o no y posteriormente será función del Magistrado establecer en qué medida debe afectar dicha circunstancia, como por ejemplo que el veredicto sea de culpabilidad pero concurra una causa de inimputabilidad que haga que se dicte una sentencia absolutoria que determine una medida de internamiento en un centro psiquiátrico.

- El hecho que determine el grado de ejecución, participación y modificación de la responsabilidad.

- El hecho por el que el acusado debe ser declarado culpable o no culpable, de manera separada si son varios delitos o varios acusados.

Aparte de esto, la Ley concede Magistrado-Presidente la facultad de añadir o no dos puntos:

\footnotetext{
528 El veredicto se rige por los principios de independencia, responsabilidad, sometimiento a la Ley, publicidad (aunque la deliberación sea secreta, la lectura del veredicto se realiza en audiencia pública), concentración, inmediación y escritura en su formalización. Bermúdez Requena, J. M. (2004). El objeto del veredicto en la Ley del Tribunal del Jurado. Granada: Comares, pág. 14.
} 
Por un lado, puede incluir los hechos o calificaciones jurídicas favorables al acusado, si no suponen una variación sustancial del hecho ni producen indefensión.

Por otro, preguntará al jurado sobre la aplicación de los beneficios de remisión condicional de la pena y la petición o no de indulto (y aquí basta la mayoría simple), extremos que no son vinculantes como sí lo es el veredicto, sino que simplemente se pide la opinión de los jurados sobre estas medidas alternativas pero sin estar obligado el Magistrado en este punto a seguir lo que el jurado establezca.

Previamente a que el Magistrado entregue al jurado el escrito con el objeto del veredicto, oirá a las partes, que pueden solicitar las inclusiones o exclusiones que consideren oportunas.

Antes de que se retiren a deliberar, el Magistrado-Presidente ha de concretar lo que sea pertinente para la elaboración de la sentencia, con el fin de que jurado sepa qué puntos debe seguir y sobre qué hechos tiene que contestar. Como ya hemos explicado en la parte histórica, tanto en el derecho comparado anglosajón como en normas anteriores en España, se realizaba un resumen de la prueba practicada, que luego fue suprimido en 1931 para evitar que los jurados se viesen influenciados por la opinión del profesional y se vulnerasen los principios de contradicción y del derecho del acusado a la última palabra. Sin embargo, siguen existiendo unas indicaciones para los legos, puesto que dicho resumen fue sustituido por las instrucciones que actualmente se les dan a los miembros del jurado.

Estas instrucciones son esenciales según la Exposición de Motivos de la propia Ley, ya que el legislador señala que en ellas radica otra de las condiciones del éxito o fracaso del enjuiciamiento por Jurado. Su inclusión se justifica para suplir las carencias de conocimientos jurídicos que deben 
tener los jurados y que esas deficiencias no sean un obstáculo que les impida ejercer su función para la que no necesitan esos conocimientos especializados, así como evitar dilaciones indebidas en la emisión del veredicto. Las instrucciones incluyen cuestiones como explicarles qué pruebas no deben tenerse en cuenta por impertinentes o ilegales, además de aclarar cualquier duda que los ciudadanos jurados presenten. Así lo establece el 54.3 LOTJ: Cuidará el Magistrado-Presidente de no hacer alusión alguna a su opinión sobre el resultado probatorio, pero sí sobre la necesidad de que no atiendan a aquellos medios probatorios cuya ilicitud o nulidad hubiese sido declarada por él. Asimismo informará que, si tras la deliberación no les hubiese sido posible resolver las dudas que tuvieran sobre la prueba, deberán decidir en el sentido más favorable al acusado, es decir, que la decisión tiene que ser razonada y basarse en pruebas que acrediten el hecho más allá de toda duda razonable y si no, se aplicará el principio in dubio pro reo.

Asimismo se les instruye sobre su función ${ }^{529}$, las reglas de deliberación y votación y cómo deben reflejar el veredicto, sin que el Magistrado revele su opinión. También se les explica la naturaleza de los hechos sobre los que versa la discusión y sobre el significado que implican determinados hechos o su ausencia; y las reglas de prueba, especialmente sobre la presunción de inocencia y que la carga de la prueba corresponde a

\footnotetext{
529 Compartimos la opinión de Hurtado Adrián acerca de que conviene recordar al jurado que en ese caso concreto son jueces y forman "parte activa en la tarea de impartir Justicia" porque así lo dice la CE. Pero sobre todo incidir en que únicamente deben juzgar los hechos, ya que se les presenta un veredicto orientado para que produzca determinados efectos jurídicos y que, a pesar de todo lo que hayan podido presenciar durante el juicio, lo innecesario o superfluo no constará, debido a la sencillez que aconseja la estructuración del objeto del veredicto. $\mathrm{Y}$ han de seguir esos términos tal y como se les articula en el objeto del veredicto. Hurtado Adrián, Á. L., "Objeto del veredicto e instrucciones", en Jorge Barreiro, A., et al. Juicio por jurado. Cuestiones teóricas y prácticas. Madrid: Dykinson, pág. 149.
} 
los acusadores. De esta forma a los jurados se les presenta de manera clara cuál es su deber, qué tienen que hacer y cómo han de hacerlo.

La siguiente etapa es la deliberación, donde los jurados, presididos por la primera persona que haya salido en el sorteo, se retiran a una sala especial acondicionada al efecto y, a puerta cerrada e incomunicados, debaten sobre el objeto del veredicto. Begué Lezaun opina que no hay lugar a dudas en que la LOTJ solamente aplica la incomunicación a la deliberación pero es cierto que existe un debate sobre si debería extenderse a todo el juicio, ya que una de las críticas que reciben los ciudadanos jurados es el poder estar influidos en casos mediáticos. En realidad, que estuvieran incomunicados desde el principio del juicio oral tampoco evitaría esa posible contaminación, si tenemos en cuenta que ya desde la instrucción y antes de que se conozca quiénes van a formar parte del jurado, en determinados supuestos todos tenemos acceso a información. En cualquier caso, no consideramos que esas opiniones puedan afectar al posterior veredicto, dado que los detalles que se hacen públicos son una mínima parte de lo que luego objetivamente van a presenciar los jurados en el juicio, que es donde se realizará la práctica de todas las pruebas y tendrán a su disposición todos los elementos que deban examinar para llegar a un veredicto adecuado ${ }^{530}$.

Si dura mucho, pueden descansar pero manteniendo la incomunicación. Esta deliberación es secreta y se impone la prohibición de revelar lo manifestado en ella $^{531}$. Pueden solicitar ampliación de instrucciones si tienen dudas o puede convocarlos el Magistrado-Presidente a una comparecencia si en el plazo de dos días no han hecho entrega del

\footnotetext{
${ }^{530}$ Begué Lezaun, op. cit., pág. 314.

${ }^{531}$ La DA $2^{\text {a }} .2$ de la LOTJ establece como infracción penal incumplir dicha obligación y fija la pena en arresto mayor y multa de 100.000 a 500.000 pesetas. La DT $11^{\mathrm{a}}$.1.e) del $\mathrm{CP}$ sustituye la pena de arresto mayor por arresto de siete a quince fines de semana. El equivalente de la multa en la moneda actual (redondeando) es de 600 a $3000 €$.
} 
acta de votación y preguntarles si existen esas dudas. Esta convocatoria a iniciativa del Magistrado es facultativa y la ley no establece más plazo que esos dos días iniciales, por lo que no hay un plazo concreto para que emitan el veredicto.

Si en dicha comparecencia ningún miembro del jurado expone alguna duda, se producirán los efectos de devolución del acta, esto es, que el Magistrado Presidente, en audiencia pública, debe explicar la justificación de la devolución y precisará cómo se deben subsanar los defectos de procedimiento o los puntos sobre los que hay que emitir nuevos pronunciamientos (art. 64 LOTJ). No cabe en ningún caso la posibilidad de devolverla por discrepar en el sentido del veredicto, sino solo impedir que tenga errores. Otro efecto que se produce es que si el acta se devuelve tres veces -y este hecho contaría como la primera-, el jurado será disuelto y tendrá que convocarse un nuevo juicio con nuevo jurado ${ }^{532}$.

Sin embargo, tras este plazo inicial, la ley no hace referencia a más plazos y hay que interpretar lo que ha querido decir el legislador, ya que no expresa si deben transcurrir otros dos días para volver a llamar al jurado o cuánto tiempo puede pasar hasta que los llame de nuevo. López Barja de Quiroga expone que seguramente lo que quiso decir el legislador era que si no hay preguntas al Magistrado y la tardanza en la emisión del veredicto no es razonable, se debe entender el mismo efecto, mientras que si es razonable, no debe aplicarse ese efecto de devolución del acta $^{533}$. No obstante, al no ser obligatoria la llamada a la comparecencia, el jurado puede estar deliberando el tiempo que el Magistrado considere oportuno,

\footnotetext{
${ }^{532}$ En este punto coincidimos con Jacobo López Barja de Quiroga cuando manifiesta que no parece muy lógico que el Magistrado deba explicar las causas que justifican la devolución del acta y la subsanación de los defectos de procedimiento, cuando aquí no se ha producido ninguna de las dos cosas. López Barja de Quiroga, op. cit., pág. 530. ${ }^{533}$ Ibid.
} 
sin necesidad de disolverlo, pero también de manera que evite que se dilate de forma injustificada para que sí se encamine a emitir el veredicto.

La deliberación será dirigida por quienes los miembros elijan como portavoz y esa persona redactará el acta y leerá el veredicto en audiencia pública.

Tras la deliberación tiene lugar la votación, que será nominal ${ }^{534}$, en voz alta y por orden alfabético, excepto el portavoz que vota en último lugar. En España se sigue un sistema de mayorías en lugar del de unanimidad, que rige en otros países en los que también existe el modelo de jurado puro o anglosajón. Santisteban Ruiz considera que el sistema de unanimidad es de contenido más rico pero que el hecho de seguir el criterio de la mayoría en España es para evitar el fracaso de la Institución ante la dificultad previsible de obtener unanimidades ${ }^{535}$.

La Exposición de Motivos de la LOTJ alega que Sin duda la regla de decisión que exige la unanimidad en el sentido de la misma para tener por producido el veredicto, se presenta como la más adecuada para compeler a los jurados a un debate más rico. Sin embargo tal regla lleva implícito un elevadísimo riesgo de fracaso de no alcanzarse tal unanimidad. Una adecuada transacción entre los objetivos de una deliberación indirectamente orientada a la votación desde su inicio, por formación de fáciles mayorías simples, y la evitación de excesivas disoluciones del Jurado, que puedan venir motivadas por la simple e injustificable obstinación de uno o pocos jurados, ha aconsejado, al menos en el inicio del funcionamiento de la Institución, una regla de decisión menos exigente.

\footnotetext{
${ }^{534}$ La Exposición de Motivos de la LOTJ argumenta esta manera de votar en que así quede identificada la posible abstención de un jurado, ya que esta se encuentra prohibida por la misma Ley.

535 Santisteban Ruiz, A. (1996). "El veredicto", en Anuario jurídico de La Rioja, no 2, pág. 405.
} 
Aunque indique que, al menos en el inicio del funcionamiento, no se ha considerado necesario modificar esta regla y es la que continúa en la actualidad.

Siguiendo la legislación anterior, ningún jurado puede abstenerse de votar, bajo pena de multa y, en todo caso, su abstención se consideraría como voto a favor de no considerar probado el hecho y de la inculpabilidad del acusado, extremo que también hay que explicar a los jurados para que no piensen que si se abstienen ese voto no se tiene en cuenta y es neutro.

Según lo que les explicó el Magistrado-Presidente, primero se votará si se consideran probados o no los hechos y el número de votos necesario es diferente dependiendo del sentido de la votación, así se requerirán al menos siete de los nueve votos para los hechos contrarios al acusado, mientras que bastará con la mayoría de cinco para los hechos favorables. Si no se obtienen las mayorías suficientes, pueden hacerse las precisiones oportunas y realizarse una segunda votación ${ }^{536}$.

Una vez alcanzada la mayoría necesaria sobre los hechos, se votará sobre la culpabilidad o no culpabilidad del acusado por cada hecho delictivo concreto, con las mismas mayorías, siete para la culpabilidad y cinco para la inculpabilidad. La ley utiliza el término "inculpabilidad" y no “inocencia” y a este respecto señala López Barja de Quiroga ${ }^{537}$ que no le parece correcto que en la ley no aparezca la palabra "inocente": "De la lectura de la ley se deduce claramente que la persona sometida a juicio por Jurado no puede ser declarada inocente y esto plantea un importante

\footnotetext{
536 "Si no se alcanza alguna de esas mayorías, no habrá veredicto válido y habrá que operar en la forma prevista en los arts. 63 [devolución del acta] y 65 LOTJ [disolución del jurado y nuevo juicio oral] (supuestos de seis o cinco votos a favor de declarar probado el hecho desfavorable)". Acuerdo del Pleno de la Sala Segunda, de 13 de marzo de 2013, sobre criterio de interpretación del art. 59.1 LOTJ en relación a las mayorías necesarias para alcanzar un veredicto.

${ }^{537}$ López Barja de Quiroga, op. cit., pág. 537.
} 
problema constitucional, pues el derecho a la presunción de inocencia implica que el acusado tiene el derecho a ser considerado inocente en tanto no se pruebe su culpabilidad y, por tanto, a que si en un juicio no ha sido probada, se declare su inocencia". Insiste en que ambos términos "inocente" y "no culpable" no son lo mismo y que la ley debería haber hecho alusión a esta diferencia e incluir que cuando los jurados emiten veredicto de inculpabilidad, afirmar que lo es porque es inocente, cuando así proceda.

Sin embargo, no estamos de acuerdo con este planteamiento, puesto que a nuestro juicio, precisamente el derecho a la presunción de inocencia recogido en el art. 24.2 CE, hace que esta ya exista de forma previa. Una persona no es inocente porque un jurado lo declare así, sino porque ya lo es con anterioridad a acudir a juicio y la inocencia se le presume, por lo que la carga de la prueba en la acusación hace que haya que demostrar su culpabilidad. Si se demuestra es "culpable" y si no, "no culpable", igual que en la legislación anglosajona, de donde tomamos nuestro modelo de jurado, el veredicto es guilty (culpable) o non guilty (no culpable) pero no innocent.

Ya hemos insistido en varias ocasiones sobre este asunto como argumento más favorable a la defensa de esta institución y es el que los miembros del jurado se pronuncian exclusivamente sobre cuestiones de hecho, nunca de derecho, por lo que a la vista de las pruebas practicadas en el juicio y tras la deliberación, decidirán si la persona acusada ha cometido un determinado hecho, no si ese hecho tiene una u otra calificación jurídica. Por ejemplo, en el caso de las sentencias que analizamos, el jurado dirá si el enjuiciado ha llevado a cabo unos actos concretos que han producido la muerte de la víctima, sin entrar a valorar si esos actos son constitutivos de homicidio o de asesinato, si concurre alevosía o 
ensañamiento, si existe imprudencia o no, si le corresponde una pena de diez o de veinte años, etc., porque por supuesto ni tienen conocimientos para ello ni es su función, ocupándose así de todos los aspectos jurídicos el Magistrado-Presidente, que es quien debe realizar todas esas valoraciones para finalmente imponer la correspondiente condena o absolución.

La jurisprudencia lo expresa del siguiente modo: "Al igual que en una sentencia se prohíben aquellas expresiones que "predeterminen el fallo", también en el "objeto del veredicto" han de estar ausentes valoraciones de ese tenor. Una proposición del veredicto no puede consistir en determinar "si hay alevosía"; o "si hubo alguna posibilidad de defensa". Habrá de construirse con una descripción de los hechos para que luego los jueces profesionales (magistrado Presidente y posteriormente los Tribunales llamados a conocer de eventuales recursos) determinen sobre esa base fáctica fijada por el jurado la subsunción jurídica adecuada" ${ }^{, 538}$.

Asimismo expresarán su criterio sobre los beneficios de remisión condicional de la pena y la petición de indulto en la sentencia, que también exige una mayoría de cinco votos. Este último extremo no vincula al Magistrado, como sí lo hace el resto del veredicto.

Finalmente se extiende un acta que contendrá los cinco siguientes apartados (art. 61 LOTJ):

1. El pronunciamiento de los hechos probados, con la fórmula: "Los jurados han deliberado sobre los hechos sometidos a su resolución y han encontrado probados, y así lo declaran por (unanimidad o

\footnotetext{
${ }^{538}$ Segundo FD de la STS 6546/2013, de 2 de diciembre, que resuelve sobre un recurso de casación por infracción de Ley, al intentar expulsar el recurrente la alevosía que convierte el homicidio en asesinato. El motivo es desestimado porque, aunque considera que una de las proposiciones del veredicto está integrada por valoraciones que no deberían haber sido objeto de votación y de plasmación, es prescindible ya que hay otras tres que el Tribunal estima que dejan clara la concurrencia de alevosía.
} 
mayoría) los siguientes...". Si lo votado ha sido el texto propuesto por el Magistrado, pueden simplemente indicar el número.

2. Los hechos no probados: "Asimismo, han encontrado no probados, y así lo declaran por (unanimidad o mayoría) los hechos descritos en los números siguientes del escrito sometido a nuestra decisión", con la referencia de los números de los párrafos de ese escrito o la reproducción del texto.

3. El veredicto de culpabilidad o inculpabilidad: "Por lo anterior, los jurados por (unanimidad o mayoría) encontramos al acusado... culpable/no culpable del hecho delictivo ${ }^{539}$ de...". Se hará el pronunciamiento separado para cada delito y cada acusado y en este momento es cuando pronunciarán su criterio sobre la aplicación de los beneficios de remisión condicional de la pena y el indulto.

4. Una sucinta explicación de las razones o elementos de convicción considerados, por los que han declarado o rechazado declarar determinados hechos como probados: "Los jurados han atendido como elementos de convicción para hacer las precedentes declaraciones a los siguientes...", cumpliendo así las exigencias del Tribunal Constitucional sobre la motivación de las resoluciones ${ }^{540}$.

5. Se indicarán los incidentes ocurridos durante la deliberación pero manteniendo el secreto obligado.

El requisito de motivación del veredicto da lugar a algunos planteamientos. Según Pérez-Cruz Martín ${ }^{541}$, que se exija al jurado argumentar por qué ha considerado una prueba o no, es criticable puesto que no se puede pedir a un jurado que argumente por qué cree a un testigo

\footnotetext{
539 En la redacción original publicada el 23 de mayo de 1995, en lugar de "hecho delictivo", la ley disponía "delito". Fue modificada por el art. 1.48 de la LO 8/1995, de 16 de noviembre y publicada al día siguiente, quedando esa expresión hasta hoy.

${ }^{540}$ Santisteban Ruiz, A., op. cit., pág. 407.

${ }^{541}$ Pérez-Cruz Martín, op. cit., págs. 333-334. 
o al acusado, ya que eso entra dentro de la valoración de la prueba y son aspectos que no pueden ser revisados por otro tribunal, y porque además, se exige también que explique los hechos no probados, cuando en la obligación de motivar las sentencias no se entra en esos extremos porque no aportan nada en una posterior revisión.

Por último, el portavoz designado redacta el acta, salvo que no esté de acuerdo con la mayoría, instante en el que los demás miembros deberán elegir otra persona para elaborarla, acto en el que puede ser ayudada por uno de los funcionarios. Todos los jurados la firmarán y, si alguno no puede, lo hará el portavoz por él. En caso de que alguien se niegue a firmar, se hará constar en la propia acta aunque la ley no establece consecuencias por esa negativa.

Extendida el acta, se entrega una copia al Magistrado-Presidente y, exceptuando los casos en los que proceda la devolución, que debe ser justificada, se convoca a las partes y el portavoz lee el veredicto en audiencia pública. Tras esto, el jurado cesa en sus funciones pero hasta ese momento, los suplentes deberán estar a disposición del Tribunal, por si deben sustituir a algún miembro en cualquier momento del proceso.

Ya se expuso anteriormente que si se tardaba durante la deliberación, el Magistrado-Presidente podía preguntar a los jurados si tenían alguna consulta y si no la había esto tenía efectos de devolución del acta. Los casos en los que el Magistrado puede devolver el acta se justifican para evitar la disolución del jurado por algún defecto subsanable, cuando aprecie una de las circunstancias que se señalan a continuación:

- Que el jurado no se haya pronunciado sobre todos los hechos.

- O sobre la culpabilidad o inculpabilidad de todos los acusados y todos los hechos delictivos imputados. 
- Si no se ha obtenido la mayoría requerida en cualquiera de los apartados.

- Que existan pronunciamientos contradictorios, tanto respecto a los hechos como a la declaración de culpabilidad o no.

- Cuando hay algún defecto relevante en el procedimiento de deliberación y votación.

No se tendrá en cuenta, ya que se anulará, cualquier hecho que no haya propuesto el Magistrado y que se haya incluido como probado e implique una alteración sustancial de los hechos o determine una responsabilidad más grave que la imputada. Antes de devolver el acta se convocará a las partes a una audiencia.

Si se devuelve el acta tres veces, en caso de que no se subsanen los errores o no se hayan logrado las mayorías necesarias, se disuelve el jurado y se convoca un nuevo juicio oral con otro distinto. No parece muy lógica esta solución que plantea el legislador, ya que, a pesar de que no se vulnera el principio non bis in idem, al no haberse dictado sentencia, no deja de tener los efectos de hacer pasar otra vez a todas las partes por un nuevo juicio, con todo lo que eso conlleva y además, si no se logran las mayorías es posible que las circunstancias sean muy complicadas y planteen las suficientes dudas como para que después de tres devoluciones, el jurado no haya llegado a una conclusión, más teniendo en cuenta que esto podría producirse si se exigiera la unanimidad pero no con el sistema de mayorías $^{542}$. Si este segundo jurado tampoco obtiene un veredicto, el Magistrado dictará sentencia absolutoria.

\footnotetext{
${ }^{542}$ En esta parte sí estamos de acuerdo con lo expuesto por López Barja de Quiroga, que propone que una solución más adecuada podría ser que si por esas causas se disolviera el jurado, se aplicara el principio a favor del reo y se dictara sentencia absolutoria, en lugar de juzgarlo otra vez por lo mismo ya que es lo que sí se hace si tras el segundo juicio el resultado es idéntico. López Barja de Quiroga, op. cit., pág. 539.
} 


\subsubsection{La sentencia.}

Regulada en el Capítulo V (arts. 67-70), en ella el Magistrado debe realizar la calificación necesaria para determinar el grado de ejecución, la participación del condenado, la procedencia o no de circunstancias modificativas de la responsabilidad criminal y concretar la pena aplicable. Para cumplir con el principio de motivación de las resoluciones ${ }^{543}$, aparte de que los jurados hagan una motivación de la valoración de la prueba ${ }^{544}$, el Magistrado motivará por qué ha estimado que existe la prueba sobre la que haya autorizado el veredicto. De esta suerte pretende la Ley obstar las críticas suscitadas en torno a la fórmula de separación del colegio decisor, tanto en lo relativo a la inescindibilidad del hecho y del derecho, como en lo concerniente a la supuesta irresponsabilidad por falta de motivación en el veredicto y sentencia, que, se dice, deberían ser inherentes a dicho sistema ${ }^{545}$.

La STS 1490/2016, de 5 de abril, es un ejemplo de caso en el que el Supremo anuló la sentencia del Tribunal Superior de Justicia que resolvió la apelación, para que diera una nueva redacción "que incluyera un examen

543 Art. $120.3 \mathrm{CE}$ : Las sentencias serán siempre motivadas y se pronunciarán en audiencia pública.

${ }^{544}$ El Catedrático de Derecho Penal de la Universidad de Navarra, Faustino Cordón Moreno, señala que la motivación aquí es mayor que la establecida en general en la LECr, dado que "no se limita a la enunciación de los hechos probados, sino que se extiende también a la valoración de la prueba, que en el proceso penal siempre es una valoración libre o en conciencia; (...) esta norma rompe con la tradición histórica -y de Derecho comparado- de que el juicio de hecho del Jurado no debe ser motivado. Pero a mi juicio, el sistema de libre valoración de la prueba ni es contrario a la motivación ni es privativo de los jueces técnicos o de carrera; valoración libre de la prueba es valoración de acuerdo con los criterios racionales, "por medio de un proceso mental razonado y acorde con las reglas del ser humano", de forma que el proceso deductivo no sea "arbitrario, irracional o absurdo" (cft. STC 174/1985) y no parece que exista obstáculo grave para que pueda ser predicado de los legos, ya que tales criterios racionales no precisan de ningún conocimiento específico, sino que forman parte de la misma condición humana". Cordón Moreno, F. (1996). "La sentencia y los recursos en el proceso ante el Tribunal del Jurado”, en Anuario jurídico de La Rioja nº 2, pág. 414.

${ }^{545}$ Exposición de Motivos de la LOTJ. 
matizado del tratamiento de la prueba por parte del Magistrado Presidente en la instancia". Y tras el nuevo recurso expone que "La sentencia que ahora se revisa da respuesta pormenorizada a esas cuestiones en relación con los elementos de valoración que hizo constar el Jurado al motivar su veredicto y el Magistrado Presidente en su sentencia".

El fallo del juez se encuentra vinculado al veredicto. Así, si este es de inculpabilidad, se dictará sentencia absolutoria en el acto y se ordenará su inmediata puesta en libertad y, si es de culpabilidad, impondrá la condena que corresponda y deberá concretar la existencia de prueba de cargo. En este caso concede la palabra al Fiscal y las demás partes para que informen:

- sobre la pena o las medidas de seguridad correspondientes,

- sobre la responsabilidad civil,

- en caso de que el jurado haya emitido un criterio favorable a los beneficios de la remisión condicional, se hará una referencia a la concurrencia de los presupuestos legales de su aplicación.

La sentencia se redacta en la forma ordinaria ${ }^{546}$ con el añadido del contenido del veredicto como hechos probados y delito objeto de condena o absolución. A ella se une el acta del Jurado.

Contra esta resolución ${ }^{547,548}$ cabe interponer recurso de apelación ${ }^{549}$ ante el Tribunal Superior de Justicia, conforme a lo dispuesto en el Libro V

\footnotetext{
${ }^{546}$ Art. 248.3 LOPJ: Las sentencias se formularán expresando, tras un encabezamiento, en párrafos separados y numerados, los antecedentes de hecho, hechos probados, en su caso, los fundamentos de derecho y, por último, el fallo. Serán firmadas por el Juez, Magistrado o Magistrados que las dicten. Este artículo se desarrolla con más detalle en el art. 142 LECr.

${ }^{547}$ El sistema de recursos cumple con lo exigido en el art. 14.5 del Pacto Internacional de Derechos Civiles y Políticos, de 19 de diciembre de 1966, ratificado por España en 1977: Toda persona declarada culpable de un delito tendrá derecho a que el fallo condenatorio y la pena que se le haya impuesto sean sometidos a un tribunal superior, conforme a lo prescrito por la ley. [En línea] [Disponible en:
} 
de la Ley de Enjuiciamiento Criminal ${ }^{550}$. Una vez más, la Exposición de Motivos de la LOTJ nos ofrece la justificación de este recurso, frente a la regulación entonces vigente del procedimiento penal ordinario que directamente era recurrible en casación ${ }^{551}$ : La nueva apelación aspira a colmar el derecho al «doble examen», o «doble instancia», en tanto su régimen cumple suficientemente con la exigencia de que tanto el fallo condenatorio como la pena impuesta sean sometidas a un tribunal superior, en función del carácter especial del procedimiento ante el Jurado, y sin perjuicio de la función propia que debe desempeñar, respecto de todos los delitos, el recurso de casación.

http://www.ohchr.org/SP/ProfessionalInterest/Pages/CCPR.aspx].

${ }^{548}$ Yáñez Velasco señala que dentro del derecho a la tutela judicial efectiva que garantiza el art. $24 \mathrm{CE}$, además del acceso a la Administración de Justicia, tiene cabida la potestad de recurrir como parte de la jurisdicción a la que se tiene derecho y, aunque la Constitución no refleje este derecho de manera expresa, se deduce a partir de la cláusula "con todas las garantías". Yáñez Velasco, R. (2001). Derecho al recurso en el proceso penal. Valencia: Tirant lo Blanch, págs. 260-264.

549 Cordón Moreno concluye que este recurso que introduce la LOTJ no abre una segunda instancia que solo se garantiza en el ámbito civil, donde predomina la prueba documental, pero no se da en el penal, debido al principio de oralidad, inmediación, publicidad y la importancia de las pruebas de carácter personal y no es posible sustituir la valoración de la prueba realizada por el Juez de primera instancia practicada según los mencionados principios. Esto es así porque excluye del ámbito del enjuiciamiento por el Tribunal superior (el TSJ) todo el juicio de hecho realizado en primera instancia y por tanto queda garantizado que "tanto el fallo condenatorio como la pena impuesta sean sometidos a un tribunal superior", como exige el mencionado Pacto Internacional de Derechos Civiles y Políticos. Cordón Moreno, op. cit., pág. 425.

${ }^{550}$ Las sentencias dictadas en el ámbito de la Audiencia Provincial y en primera instancia, por el Magistrado-Presidente del Tribunal del Jurado, serán apelables para la Sala de lo Civil y Penal del Tribunal Superior de Justicia de la correspondiente Comunidad Autónoma. Art. 846 bis a).

${ }^{551}$ La Ley 41/2015, de 5 de octubre, de modificación de la Ley de Enjuiciamiento Criminal para la agilización de la justicia penal y el fortalecimiento de las garantías procesales, en vigor desde el desde el 6 de diciembre de ese año, introduce el art. 846 ter., por el que las sentencias dictadas por las Audiencias Provinciales en primera instancia son recurribles en apelación ante las Salas de lo Civil y Penal de los Tribunales Superiores de Justicia. En la Exposición de Motivos se justifica también por el art. 14.5 del Pacto Internacional de Derechos Civiles y Políticos y así generalizar la segunda instancia, estableciendo la misma regulación actualmente prevista para la apelación de las sentencias dictadas por los juzgados de lo penal en el proceso abreviado. 
Para ello, la Ley adecua los motivos de impugnación previstos a ese carácter especialísimo del procedimiento y atribuye la competencia resolutiva a las Salas de lo Civil y Penal de los Tribunales Superiores de Justicia, lo cual, aparte de los necesarios ajustes en medios personales, responde a una ya antigua aspiración en la delimitación competencial para el conocimiento de la apelación.

Y también la jurisprudencia ha establecido que "la casación «descansa sobre el recurso de apelación»"552.

Los motivos se expresan en el art. 846 bis c) LECr:

1. Que en el procedimiento o en la sentencia se produzca un quebrantamiento de normas y garantías procesales, que cause indefensión, siempre que se haya efectuado la oportuna reclamación de la subsanación y se haya formulado la correspondiente protesta al producirse la infracción denunciada. Uno de los motivos que más se alegan a la hora de recurrir en apelación, es la vulneración de la tutela judicial efectiva debido al principio de interdicción de la arbitrariedad, argumentando que la motivación del veredicto del jurado sea "insuficiente, arbitraria y contradictoria"

2. Infracción de precepto constitucional o legal en la calificación jurídica de los hechos o en la determinación de la pena, de las medidas de seguridad o la responsabilidad civil.

3. Que se haya solicitado la disolución del Jurado por la inexistencia de prueba de cargo y se hubiera desestimado de forma indebida.

4. Si se ha disuelto el Jurado sin que procediera.

552 STS 2940/2016, de 9 de junio, dentro del tercer motivo del recurso de casación interpuesto por uno de los condenados.

553 Tomé García, J. A. (2013). Recurso de apelación contra sentencias en el proceso penal. Madrid: Colex, pág. 128. 
5. Por conculcar la presunción de inocencia, cuando la condena no tenga base razonable según la prueba practicada en el juicio.

Y contra ese recurso de apelación, cabe casación ante el Tribunal Supremo, como dispone el art. 57 de la Ley Orgánica del Poder Judicial: $L a$ Sala de lo Penal del Tribunal Supremo conocerá:

$1^{\circ}$ De los recursos de casación, revisión y otros extraordinarios en materia penal que establezca la ley ${ }^{554}$.

${ }^{554}$ Establecido también en el art. 847.1.1 ${ }^{\circ}$ de la LECr, tanto por infracción de ley como por quebrantamiento de forma, contra las sentencias dictadas en única instancia o en apelación por la Sala de lo Civil y de lo Penal. 


\section{ANÁLISIS DE LAS SENTENCIAS ESTUDIADAS.}

Con objeto de comprobar cuál es el sentido del veredicto, hemos examinado una serie de resoluciones tras la celebración de los correspondientes juicios con jurado.

Por una parte, observaremos si el jurado tiende más a declarar la culpabilidad o la inculpabilidad, para comprobar si son severos o no en sus dictámenes y, por otra, compararemos las resoluciones de las Audiencias Provinciales vinculadas a dichos veredictos, con las que emiten los tribunales en segunda instancia para, de esta forma, ver si el jurado emitió un veredicto correcto que posteriormente confirme el TSJ y el TS o si, por el contrario, las sentencias de las Audiencias Provinciales son revocadas y cambian ese sentido del veredicto.

Se han tomado como referencia las sentencias en casos de delitos de homicidios y asesinatos dictadas en el ámbito territorial de Castilla y León desde la entrada en vigor de la ley (23 de noviembre de 1995) hasta el año 2017 incluido.

En total, se han analizado trescientas treinta y una sentencias, que se distribuyen entre los distintos órganos judiciales examinados, de la siguiente forma:

- 193 sentencias de las nueve Audiencias Provinciales: 12 de Ávila, 44 de Burgos, 45 de León, 10 de Palencia, 17 de Salamanca, 13 de Segovia, 7 de Soria, 32 de Valladolid y 13 de Zamora.

- 99 sentencias del Tribunal Superior de Justicia de Castilla y León, en recurso de apelación.

- 39 sentencias del Tribunal Supremo, en recurso de casación. 
Hay que tener en cuenta que únicamente se han estudiado las sentencias en las que ha habido un veredicto del jurado. No se han incluido aquellos procedimientos en los que, a pesar haberse dictado auto de apertura de juicio oral ante el Tribunal del Jurado, finalmente no se ha celebrado por alguna de las causas de disolución del Jurado previstas en la ley, a saber:

a) Disolución anticipada por inexistencia de prueba de cargo que pueda fundar una condena del acusado, en cuyo caso se dictará sentencia absolutoria motivada (art. 49 LOTJ).

b) Conformidad de las partes, con igual disolución sin juicio ni veredicto y con sentencia del Magistrado-Presidente (art. 50 LOTJ).

c) Desistimiento en la petición de condena del acusado y sentencia absolutoria del Magistrado-Presidente.

También debemos resaltar que no se han considerado otras variables que pueden influir, como el hecho de que en muchas ocasiones los hechos probados son tan claros, que existe una alta probabilidad de que los condenados lo hubieran sido de igual manera si no hubiesen sido juzgados por un tribunal popular. Esta circunstancia es más factible además por la clase de delitos que se están analizando, los homicidios y los asesinatos.

De las ciento noventa y tres sentencias dictadas por las nueve Audiencias Provinciales, noventa y dos de ellas son sobre juicios por asesinato y noventa y seis por homicidio, es decir, casi la misma cantidad de cada uno. Hay cinco casos en los que se producen ambas figuras delictivas por los siguientes motivos: 
- En la SAP VA 263/2000, de 17 de febrero, hubo dos víctimas. El autor fue condenado por homicidio al ser autor de la muerte de su mujer y por asesinato al causar la muerte de uno de sus hijos.

- En la SAP ZA 373/2002, de 19 de junio, el Ministerio Fiscal y la defensa califican los hechos como constitutivos de homicidio, mientras que las acusaciones particulares lo hicieron como asesinato. Finalmente el acusado fue declarado no culpable de ambos delitos y por lo tanto absuelto.

- En la SAP P 228/2003, de 12 de mayo, también existen diferentes calificaciones. El Fiscal califica los hechos como homicidio y la acusación particular como asesinato. Se emitió veredicto de inculpabilidad y fue absuelto de los dos tipos delictivos.

- En la SAP BU 1208/2010, de 24 de septiembre, hubo dos víctimas. La acusada fue condenada por homicidio al matar a su madre y por asesinato al matar a su hijo. Se dictó sentencia de conformidad.

- En la SAP VA 480/2015, de 8 de mayo, el Ministerio Fiscal y la defensa calificaron como homicidio y la acusación particular como asesinato. El jurado declaró al acusado culpable del delito de homicidio y no culpable por el delito de asesinato.

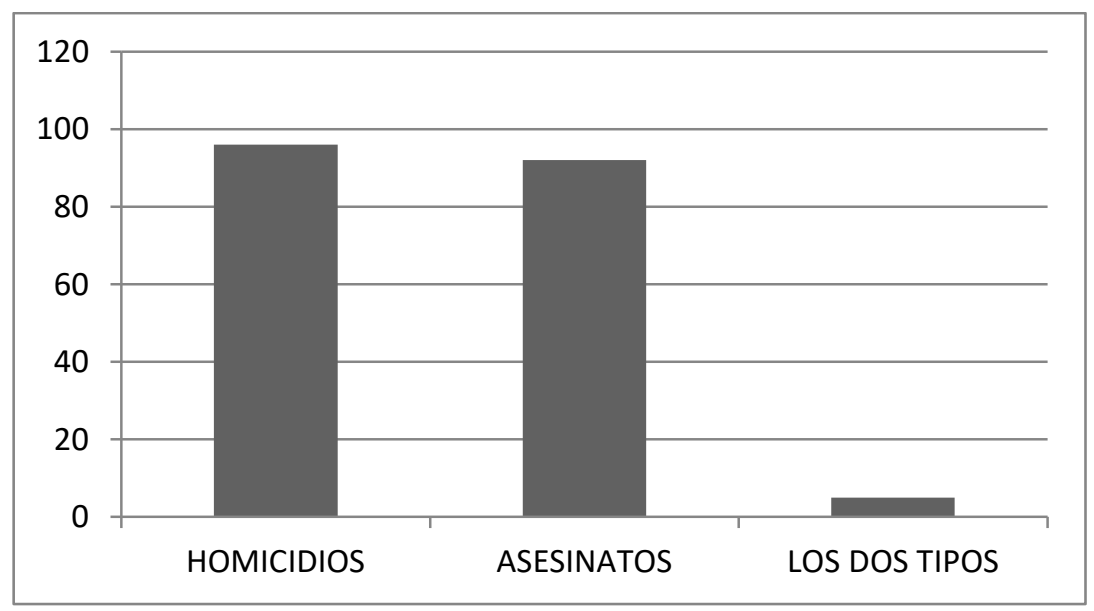

Gráfico 01: tipos delictivos juzgados por el jurado. 
Los noventa y seis homicidios se encuentran repartidos en: 5 de Ávila, 18 de Burgos, 25 de León, 6 de Palencia, 11 de Salamanca, 8 de Segovia, 4 de Soria, 12 de Valladolid y 7 de Zamora.

Los noventa y dos asesinatos se distribuyen territorialmente en: 7 de Ávila, 25 de Burgos, 20 de León, 4 de Palencia, 6 de Salamanca, 5 de Segovia, 3 de Soria, 18 de Valladolid y 5 de Zamora.

Por provincias, en general, también es parecido el número de homicidios que el de asesinatos, con una ligera diferencia más significativa en León, Salamanca y Segovia a favor de los homicidios y sin embargo más asesinatos que homicidios en Valladolid. Las provincias en las que más delitos de esta clase se han cometido son Burgos y León, tanto en términos absolutos, como en términos relativos, si tenemos en cuenta la población comparándolo por ejemplo con Valladolid, que es la más poblada de las nueve.

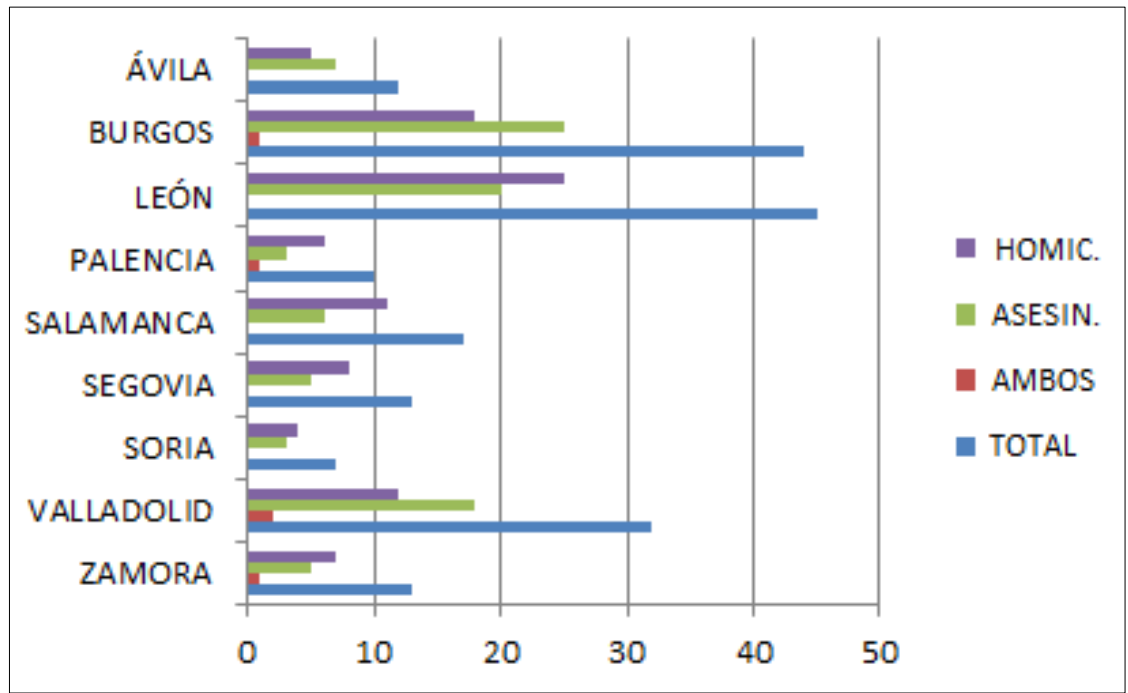

Gráfico 02: comparativa entre estos delitos por provincias.

De los 101 homicidios enjuiciados, solamente 14 son por imprudencia. En cuanto a los asesinatos, las circunstancias que lo califican se clasifican de la siguiente forma: 
- 85 por alevosía, claramente la circunstancia más común que transforma un homicidio en asesinato.

- Ninguno por precio, recompensa o promesa.

- 5 con ensañamiento.

- Ninguno para facilitar la comisión de otro o evitar que se descubra. También hay que tener en cuenta que esta cuarta circunstancia lleva en vigor bastantes menos años que las otras tres.

- En 6 de los asesinatos se da alevosía y ensañamiento.

- En 1 hay alevosía y precio.

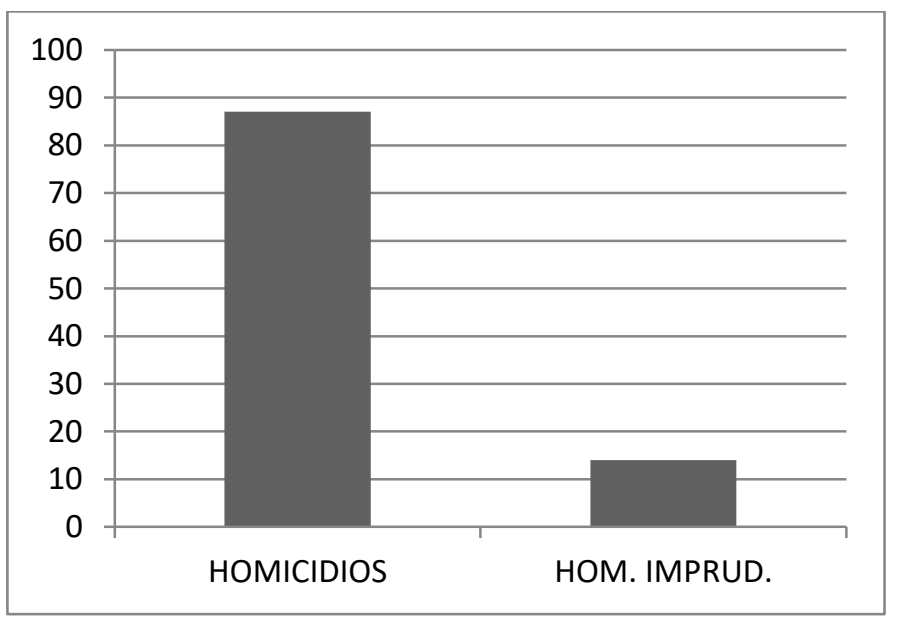

Gráfico 03: número de homicidios enjuiciados.

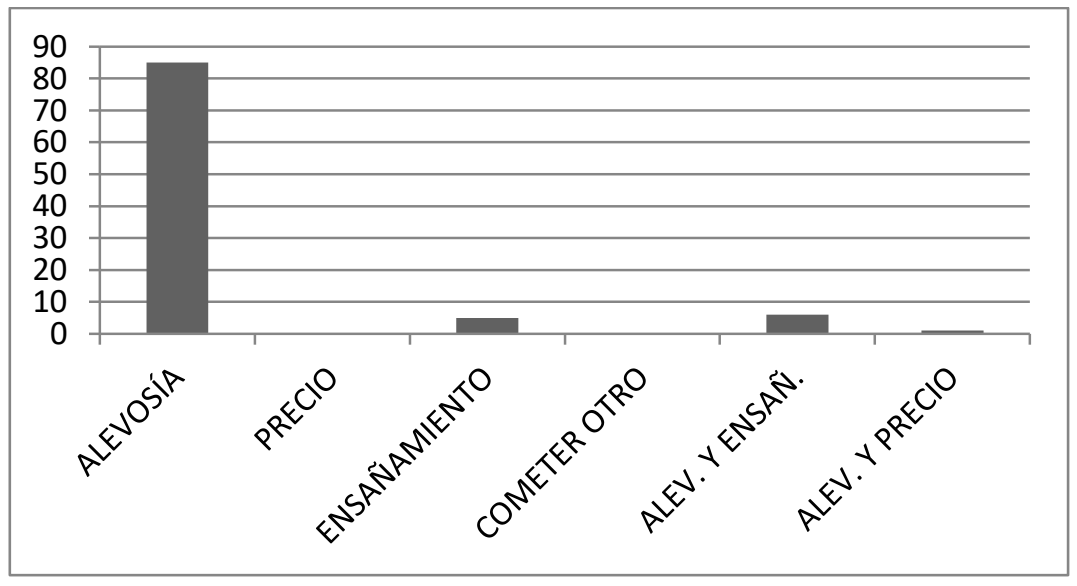

Gráfico 04: asesinatos en función de la circunstancia que los califica. 
Asimismo se ha analizado como variable el sexo del acusado para ver si existe alguna diferencia respecto al tratamiento que el jurado da a hombres y a mujeres, si es más benévolo con alguno de los dos. Cabe destacar la gran desigualdad en el número de acusados varones y hembras: 194 hombres por 35 mujeres:

- Los hombres, 104 son acusados de homicidio (15 de ellos por imprudencia) y 90 por asesinato. A cuatro de los 194 se les acusa de los dos delitos.

- De las mujeres, 13 están acusadas de homicidio (3 de ellos por imprudencia) y a 21 se las juzga por asesinato. Otra más es acusada de ambos tipos delictivos.

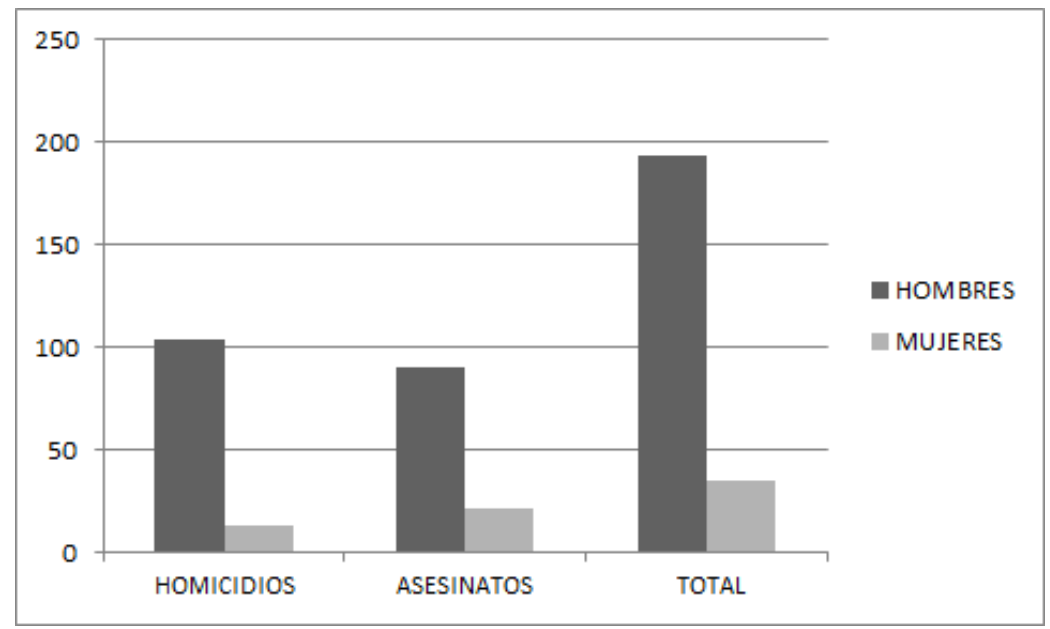

Gráfico 05: distribución de los homicidios y los asesinatos en función del sexo de la persona que los ha cometido.

A pesar de la diferencia significativa entre el número de acusados hombres y las acusadas mujeres, hay que destacar que ellos han cometido más homicidios y ellas más asesinatos.

Respecto a las 193 resoluciones de las Audiencias Provinciales, en la mayoría de las ocasiones el jurado emitió un veredicto de culpabilidad. Aunque ese sea el número de sentencias, el de veredictos es diferente, 
puesto que en algunos hechos había más de un encausado y en otros casos no hubo veredicto al dictarse sentencia de conformidad. Los resultados han sido los siguientes:

- En 136 juicios consideraron culpable al acusado y por lo tanto se les impuso una condena a través de la correspondiente sentencia. En 12 de esos juicios había varios acusados y en uno se juzgaban los dos delitos, por lo que en realidad los veredictos de culpabilidad han sido 17 más, lo que hace un total de 153.

- En 12 emitieron veredicto de inculpabilidad exclusivamente. En cuatro de ellos se juzgaba a dos personas y en otros dos se enjuiciaban los dos delitos, por lo tanto han sido 18 declaraciones de no culpable.

- En 10 se dieron ambos veredictos culpable/no culpable. En 9 de ellas porque había varios acusados y en la restante porque el encausado fue declarado no culpable de homicidio y culpable de asesinato (SAP VA 480/2015). En estos 10 procesos se han emitido 15 veredictos de culpabilidad y 11 de inculpabilidad.

Por lo tanto, sumados estos a los procedimientos en los que exclusivamente fue dictado veredicto de culpabilidad, son 168 culpables y 29 el total de declarados no culpables.

- En 3 de las sentencias, a pesar de que eran procedimientos sometidos al Tribunal del Jurado, no llegó a haber veredicto porque el Magistrado-Presidente falló la absolución del acusado por la eximente de anomalía o alteración psíquica del 20.1 del $\mathrm{CP}^{555}$. Una de ellas fue absolución por desistimiento (SAP SA 559/2010, por delito de homicidio), también en base a la eximente

${ }^{555}$ El que al tiempo de cometer la infracción penal, a causa de cualquier anomalía o alteración psíquica, no pueda comprender la ilicitud del hecho o actuar conforme a esa comprensión. 
de alteración psíquica, con la posterior medida de internamiento psiquiátrico. Conforme al art. 51 de la LOTJ, Cuando el Ministerio Fiscal y demás partes acusadoras, en sus conclusiones definitivas, o en cualquier momento anterior del juicio, manifestasen que desisten de la petición de condena del acusado, el Magistrado-Presidente disolverá el Jurado y dictará sentencia absolutoria.

- En 32 de los casos no hubo lugar al veredicto porque se dictó una sentencia de conformidad y según el art. 50 de la LOTJ, se procederá a disolver el jurado cuando las partes interesen que se dicte sentencia de conformidad con el escrito de calificación que solicite pena de mayor gravedad, o con el que presentaren en el acto, suscrito por todas, sin inclusión de otros hechos que los objeto del juicio, ni calificación más grave que la incluida en las conclusiones provisionales. Si una de las funciones del jurado es declarar si se consideran probados o no los hechos y en estos casos los hechos no se discuten porque ambas partes se conforman, no hay nada que dilucidar y por tanto no tiene sentido formar el jurado. De estas 32 sentencias:

- En 27 se condenó por conformidad. Una de ella con tres acusados y otra con condenas por los dos tipos penales.

- En 5 hubo absolución por conformidad, al concurrir, en todas ellas, la eximente completa de anomalía o alteración psíquica del art. 20.1 CP y se dicta la medida de internamiento en un centro psiquiátrico. 


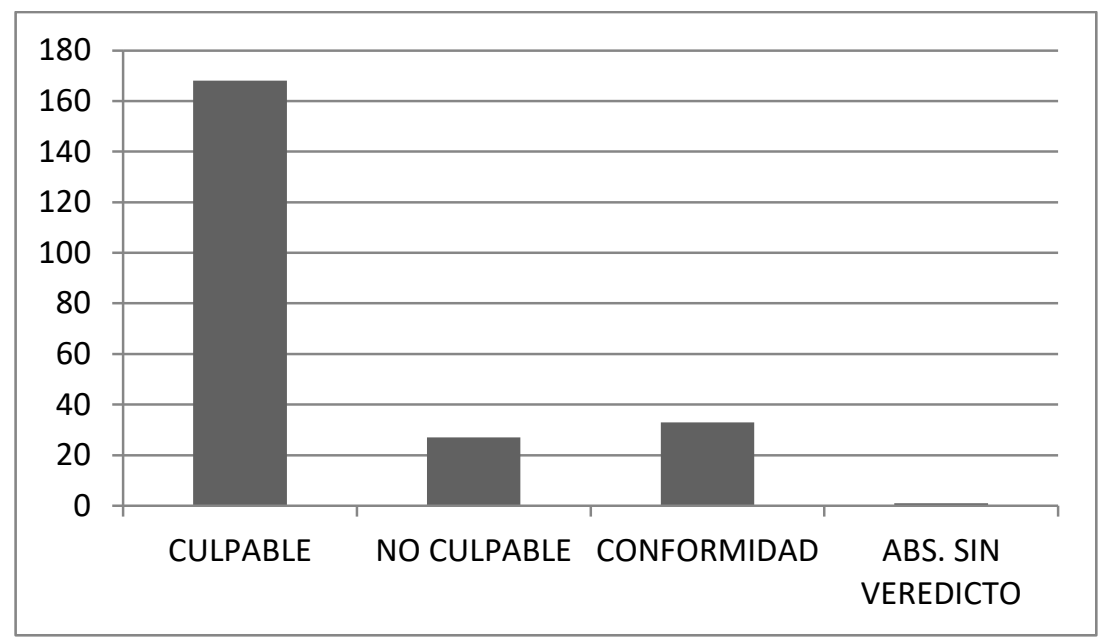

Gráfico 06: resultado de los veredictos.

En la siguiente tabla figuran las 193 resoluciones de las Audiencias Provinciales, con indicación de:

- Número de Sentencia.

- Provincia a la que corresponde la Audiencia en la que se ha enjuiciado cada caso.

- Si el delito es homicidio o asesinato. Se señala a su vez:

- Cuáles de los homicidios son por imprudencia, con una "I".

- La circunstancia que califica cada asesinato, con "A" la alevosía; "P", precio, recompensa o promesa; "E" el ensañamiento. En algunas concurren varias. No hay ningún asunto en el que se haya dado la cuarta circunstancia recogida en el art. 139 CP, para facilitar la comisión de otro delito o para evitar que se descubra.

- El veredicto emitido por el jurado, culpable o no culpable. También se hace constar en qué casos hubo sentencia de conformidad y por lo tanto el jurado fue disuelto y no se emitió veredicto.

- Sexo de la persona enjuiciada: hombre/mujer. Y número, entre paréntesis, si hay más de un acusado. 
Se destacan en negrita las sentencias que han sido recurridas, hecho que analizaremos más adelante.

\begin{tabular}{|c|c|c|c|c|}
\hline SAP & PROVINCIA & DELITO & VEREDICTO & SEXO DEL ACUSADO \\
\hline $1 / 1996$ & PALENCIA & HOMICIDIO & CULPABLE & HOMBRE \\
\hline $7 / 1997 *$ & PALENCIA & HOMICIDIO & CULPABLE & HOMBRE \\
\hline 10/1997* & SALAMANCA & HOMICIDIO & CULPABLE & HOMBRE \\
\hline $2 / 1997$ & ZAMORA & HOMICIDIO & CULPABLE & HOMBRE \\
\hline $72 / 1997$ & BURGOS & ASESINATO-A & ABSUELTO & HOMBRE \\
\hline 4/1998* & VALLADOLID & ASESINATO-A & CULPABLE & HOMBRE \\
\hline $3 / 1998 *$ & VALLADOLID & ASESINATO-A & CULPABLE & HOMBRE \\
\hline $5 / 1998 *$ & SORIA & HOMICIDIO-I & NO CULPABLES & HOMBRES (2) \\
\hline $163 / 1998$ & ZAMORA & HOMICIDIO & NO CULPABLES & HOMBRES (2) \\
\hline 8/1998* & BURGOS & HOMICIDIO & CULPABLE & HOMBRE \\
\hline $881 / 1998$ & VALLADOLID & ASESINATO-A & CULPABLE-ABSUELTO & HOMBRE \\
\hline $687 / 1998$ & LEÓN & HOMICIDIO-I & CULPABLE & HOMBRE \\
\hline 9/1998* & VALLADOLID & ASESINATO-A & CULPABLE & HOMBRE \\
\hline $575 / 1998$ & BURGOS & HOMICIDIO & CULPABLE & HOMBRE \\
\hline $1261 / 1998$ & LEÓN & HOMICIDIO & CULPABLE & HOMBRE \\
\hline $554 / 1998$ & ZAMORA & HOMICIDIO & CONFORMIDAD & HOMBRE \\
\hline $1353 / 1998$ & LEÓN & HOMICIDIO-I & CULPABLE & HOMBRE \\
\hline $305 / 1998$ & SORIA & ASESINATO-A & CULPABLE/NO CULPABLE & HOMBRES (2) \\
\hline $127 / 1999$ & ÁVILA & HOMICIDIO-I & CULPABLE & HOMBRE \\
\hline $374 / 1999$ & LEÓN & HOMICIDIO & NO CULPABLE & HOMBRE \\
\hline $907 / 1999$ & VALLADOLID & HOMICIDIO & CULPABLE & HOMBRE \\
\hline $733 / 1999$ & BURGOS & ASESINATO-A & CULPABLE & HOMBRE \\
\hline $535 / 1999$ & SALAMANCA & HOMICIDIO & CONFORMIDAD & MUJER \\
\hline 1090/1999 & VALLADOLID & ASESINATO-A & CULPABLE & MUJER \\
\hline $557 / 1999$ & SALAMANCA & HOMICIDIO & CULPABLE & HOMBRE \\
\hline $566 / 1999$ & SALAMANCA & HOMICIDIO & CULPABLE & HOMBRE \\
\hline $1118 / 1999$ & BURGOS & HOMICIDIO-I & CULPABLE & MUJER \\
\hline $859 / 1999$ & LEÓN & ASESINATO-A & CULPABLE & MUJER \\
\hline 935/1999 & LEÓN & HOMICIDIO & CULPABLE & HOMBRE \\
\hline $1418 / 1999$ & VALLADOLID & ASESINATO-A & CULPABLE & HOMBRE \\
\hline $398 / 1999$ & ÁVILA & HOMICIDIO-I & CULPABLE & HOMBRE \\
\hline $170 / 2000$ & LEÓN & HOMICIDIO-I & CONFORMIDAD & HOMBRE \\
\hline $31 / 2000$ & SORIA & HOMICIDIO & CULPABLE & HOMBRE \\
\hline $263 / 2000$ & VALLADOLID & HOMIC./ASES.-A & CULPABLE & HOMBRE \\
\hline $491 / 2000$ & BURGOS & ASESINATO-A/E & CULPABLE/NO CULPABLE & HOMBRES (2) \\
\hline $604 / 2000$ & BURGOS & ASESINATO-A & CONFORMIDAD & MUJER \\
\hline $1019 / 2000$ & LEÓN & HOMICIDIO-I & CULPABLE & HOMBRE \\
\hline $398 / 2000$ & SALAMANCA & ASESINATO-A & CULPABLE & HOMBRE \\
\hline $1093 / 2000$ & LEÓN & HOMICIDIO & CONFORMIDAD & HOMBRE \\
\hline $1565 / 2000$ & LEÓN & HOMICIDIO & CONFORMIDAD & HOMBRE \\
\hline $1099 / 2000$ & BURGOS & HOMICIDIO & CULPABLE & HOMBRE \\
\hline $1157 / 2000$ & BURGOS & HOMICIDIO & CULPABLE & HOMBRE \\
\hline
\end{tabular}




\begin{tabular}{|c|c|c|c|c|}
\hline $1968 / 2000$ & LEÓN & ASESINATO-A & CULPABLE & HOMBRE \\
\hline $442 / 2000$ & SEGOVIA & ASESINATO-A & CULPABLE & HOMBRE \\
\hline $2368 / 2000$ & LEÓN & ASESINATO-A & CULPABLES & HOMBRE Y MUJER \\
\hline $16 / 2001$ & ÁVILA & ASESINATO-A & CULPABLE/NO CULPABLE & HOMBRES (2) \\
\hline $256 / 2001$ & BURGOS & HOMICIDIO-I & CULPABLES & HOMBRE Y MUJER \\
\hline $198 / 2001$ & PALENCIA & ASESINATO-A & CULPABLE & HOMBRE \\
\hline $499 / 2001$ & VALLADOLID & HOMICIDIO & CULPABLE & HOMBRE \\
\hline $204 / 2001$ & ÁVILA & ASESINATO-A & CULPABLES & HOMBRES (2) \\
\hline $1892 / 2001$ & LEÓN & HOMICIDIO & CULPABLE & HOMBRE \\
\hline $469 / 2001$ & ÁVILA & ASESINATO-A & CONFORMIDAD & MUJER \\
\hline $805 / 2001$ & SALAMANCA & HOMICIDIO & CONFORMIDAD & MUJER \\
\hline $2066 / 2001$ & LEÓN & HOMICIDIO & CONFORMIDAD & HOMBRE \\
\hline $298 / 2002$ & LEÓN & HOMICIDIO & NO CULPABLE & MUJER \\
\hline $180 / 2002$ & ÁVILA & ASESINATO-A & CONFORMIDAD & MUJER \\
\hline $771 / 2002$ & BURGOS & HOMICIDIO & CULPABLE & HOMBRE \\
\hline $244 / 2002$ & SEGOVIA & ASESINATO-A/E & CULPABLE & HOMBRE \\
\hline $373 / 2002$ & ZAMORA & HOMIC./ASES.-A & NO CULPABLE & HOMBRE \\
\hline $1245 / 2002$ & BURGOS & ASESINATO-A & CULPABLE & HOMBRE \\
\hline $2089 / 2002$ & LEÓN & ASESINATO-A & CULPABLE & HOMBRE \\
\hline $1 / 2003 *$ & LEÓN & ASESINATO-A & CULPABLES & HOMBRE Y MUJER \\
\hline $117 / 2003$ & LEÓN & HOMICIDIO & CULPABLE & HOMBRE \\
\hline $104 / 2003$ & BURGOS & ASESINATO-E & CONFORMIDAD & HOMBRE \\
\hline $200 / 2003$ & SALAMANCA & HOMICIDIO & CULPABLE & HOMBRE \\
\hline $537 / 2003$ & VALLADOLID & HOMICIDIO & CULPABLE & HOMBRE \\
\hline $460 / 2003$ & LEÓN & ASESINATO-A & CONFORMIDAD & HOMBRE \\
\hline $228 / 2003$ & PALENCIA & HOMIC./ASES.-A & NO CULPABLE & HOMBRE \\
\hline $1011 / 2003$ & VALLADOLID & HOMICIDIO & CULPABLE & HOMBRE \\
\hline $1558 / 2003$ & LEÓN & HOMICIDIO & CULPABLE & HOMBRE \\
\hline $1112 / 2003$ & BURGOS & HOMICIDIO & CONFORMIDAD & HOMBRE \\
\hline $1545 / 2003$ & VALLADOLID & HOMICIDIO & CULPABLE & MUJER \\
\hline 9/2003* & LEÓN & HOMICIDIO & CULPABLE & MUJER \\
\hline $373 / 2004$ & SALAMANCA & HOMICIDIO & CULPABLE & HOMBRE \\
\hline $4 / 2004 *$ & SEGOVIA & ASESINATO-A & CULPABLES & HOMBRES (2) \\
\hline $752 / 2004$ & BURGOS & HOMICIDIO & CULPABLE & HOMBRE \\
\hline $382 / 2004$ & SALAMANCA & ASESINATO-A & CULPABLE & HOMBRE \\
\hline $1071 / 2004$ & BURGOS & HOMICIDIO & NO CULPABLE & HOMBRE \\
\hline $760 / 2004$ & SALAMANCA & HOMICIDIO & CULPABLES & HOMBRES (3) \\
\hline $347 / 2005$ & VALLADOLID & HOMICIDIO & CULPABLE & HOMBRE \\
\hline $1667 / 2005$ & VALLADOLID & ASESINATO-A & CULPABLE & HOMBRE \\
\hline $382 / 2005$ & SALAMANCA & HOMICIDIO & CULPABLE/NO CULPABLE & HOMBRES (2) \\
\hline $1009 / 2005$ & BURGOS & ASESINATO-A & CULPABLE & HOMBRE \\
\hline $1098 / 2005$ & LEÓN & HOMICIDIO & NO CULPABLES & HOMBRES (2) \\
\hline $2 / 2005 *$ & SEGOVIA & HOMICIDIO-I & CULPABLE & HOMBRE \\
\hline $483 / 2005$ & ZAMORA & HOMICIDIO & CULPABLE & HOMBRE \\
\hline $1388 / 2005$ & LEÓN & ASESINATO-E & CONFORMIDAD & HOMBRE \\
\hline $1355 / 2005$ & LEÓN & ASESINATO-A & CULPABLE & HOMBRE \\
\hline $10 / 2005^{*}$ & BURGOS & ASESINATO-A & CULPABLE & HOMBRE \\
\hline
\end{tabular}




\begin{tabular}{|c|c|c|c|c|}
\hline $11 / 2005^{*}$ & LEÓN & HOMICIDIO & NO CULPABLES & HOMBRES (2) \\
\hline $6 / 2006^{*}$ & BURGOS & ASESINATO-A & CULPABLE & HOMBRE \\
\hline $7 / 2006 *$ & ZAMORA & HOMICIDIO-I & CULPABLE & HOMBRE \\
\hline $120 / 2006$ & BURGOS & HOMICIDIO & CULP./NO CULPABLES (2) & HOMBRES (3) \\
\hline $238 / 2006$ & LEÓN & HOMICIDIO & CONFORMIDAD & HOMBRES (3) \\
\hline $151 / 2006$ & BURGOS & ASESINATO-A & ABSOLUCIÓN & HOMBRE \\
\hline $667 / 2006$ & PALENCIA & HOMICIDIO & CONFORMIDAD & HOMBRE \\
\hline $5 / 2006^{*}$ & SORIA & HOMICIDIO & CULPABLE & HOMBRE \\
\hline $9 / 2006 *$ & BURGOS & HOMICIDIO & CULPABLE & HOMBRE \\
\hline $2 / 2007 *$ & LEÓN & ASESINATO-A & CULPABLE & HOMBRE \\
\hline $261 / 2007$ & SEGOVIA & HOMICIDIO & CULPABLE & HOMBRE \\
\hline $1172 / 2007$ & BURGOS & ASESINATO-A & CULPABLE & MUJER \\
\hline $1339 / 2007$ & LEÓN & ASESINATO-A & CULPABLE & HOMBRE \\
\hline 1171/2007 & BURGOS & HOMICIDIO & CULPABLE & HOMBRE \\
\hline $1174 / 2007$ & BURGOS & HOMICIDIO & CULPABLE & HOMBRE \\
\hline $109 / 2008$ & VALLADOLID & HOMICIDIO & CULPABLE & HOMBRE \\
\hline $2 / 2008 *$ & SEGOVIA & ASESINATO.A/E & NO CULPABLE & HOMBRE \\
\hline $472 / 2008$ & PALENCIA & ASESINATO-A/P & CULPABLES & HOMB. (1) MUJE. (2) \\
\hline $255 / 2008$ & SEGOVIA & HOMICIDIO & CULPABLE & HOMBRE \\
\hline $1194 / 2008$ & VALLADOLID & ASESINATO-A & CULPABLE & HOMBRE \\
\hline $35 / 2009$ & ÁVILA & HOMICIDIO & CONFORMIDAD & HOMBRE \\
\hline $27 / 2009$ & SALAMANCA & ASESINATO-A & CULPABLE & HOMBRE \\
\hline $65 / 2009$ & ÁVILA & ASESINATO-A & CULPABLE & HOMBRE \\
\hline $1480 / 2009$ & VALLADOLID & ASESINATO-A & CULPABLE & HOMBRE \\
\hline $1476 / 2009$ & VALLADOLID & ASESINATO-A & CULPABLE & MUJER \\
\hline $831 / 2009$ & BURGOS & ASESINATO-A & CULPABLE & HOMBRE \\
\hline $1239 / 2009$ & VALLADOLID & ASESINATO-A & CULPABLE & HOMBRE \\
\hline $669 / 2009$ & SALAMANCA & HOMICIDIO & CONFORMIDAD & HOMBRE \\
\hline $1238 / 2009$ & BURGOS & HOMICIDIO & CULPABLE & HOMBRE \\
\hline $786 / 2010$ & LEÓN & ASESINATO-A & CONFORMIDAD & MUJER \\
\hline $669 / 2010$ & VALLADOLID & HOMICIDIO & CULPABLE & HOMBRE \\
\hline $1208 / 2010$ & BURGOS & ASES.-A/HOMIC. & CONFORMIDAD & MUJER \\
\hline $1160 / 2010$ & VALLADOLID & HOMICIDIO & CULPABLE & MUJER \\
\hline $1292 / 2010$ & BURGOS & HOMICIDIO & CULPABLE & HOMBRE \\
\hline $1337 / 2010$ & BURGOS & ASESINATO-A & CONFORMIDAD & HOMBRE \\
\hline $406 / 2010$ & ZAMORA & HOMICIDIO & CULPABLE & HOMBRE \\
\hline $397 / 2010$ & SEGOVIA & HOMICIDIO & CONFORMIDAD & HOMBRE \\
\hline $1563 / 2010$ & VALLADOLID & HOMICIDIO & ABSUELTO & HOMBRE \\
\hline $622 / 2010$ & SALAMANCA & ASESINATO-A & CULPABLE & HOMBRE \\
\hline $1496 / 2010$ & BURGOS & HOMICIDIO & CONFORMIDAD & HOMBRE \\
\hline $559 / 2010$ & PALENCIA & ASESINATO-A/E & CULPABLE-ABSUELTO & HOMBRE \\
\hline $492 / 2010$ & ÁVILA & HOMICIDIO & CULPABLE & HOMBRE \\
\hline $233 / 2011$ & LEÓN & HOMICIDIO & CONFORMIDAD & HOMBRE \\
\hline $246 / 2011$ & VALLADOLID & HOMICIDIO & CULPABLE & HOMBRE \\
\hline $175 / 2011$ & SALAMANCA & ASESINATO-A & CULPABLE & HOMBRE \\
\hline $175 / 2011$ & SEGOVIA & HOMICIDIO & NO CULPABLE & HOMBRE \\
\hline $364 / 2011$ & SALAMANCA & HOMICIDIO-I & CULPABLE & HOMBRE \\
\hline
\end{tabular}




\begin{tabular}{|c|c|c|c|c|}
\hline $809 / 2011$ & BURGOS & ASESINATO-A & CULPABLE & HOMBRE \\
\hline $916 / 2011$ & BURGOS & ASESINATO-A & CULPABLE & HOMBRE \\
\hline $540 / 2011$ & ZAMORA & ASESINATO-A & CULPABLE & HOMBRE \\
\hline $1153 / 2011$ & BURGOS & ASESINATO-A & CULPABLE & HOMBRE \\
\hline $89 / 2012$ & BURGOS & HOMICIDIO-I & CULPAB. (3)/NO CULP. (1) & HOMBRES (4) \\
\hline $556 / 2012$ & BURGOS & ASESINATO-A & CULPABLE & MUJER \\
\hline $7 / 2012 *$ & BURGOS & ASESINATO-A & CULPABLE & HOMBRE \\
\hline $851 / 2012$ & BURGOS & ASESINATO-A & CULPABLE & HOMBRE \\
\hline $1111 / 2012$ & VALLADOLID & ASESINATO-A & CONFORMIDAD & MUJER \\
\hline $919 / 2012$ & BURGOS & ASESINATO-A & CULPABLE & MUJER \\
\hline $1028 / 2012$ & BURGOS & ASESINATO-A & CONFORMIDAD & HOMBRE \\
\hline $233 / 2012$ & SORIA & ASESINATO-A & CULPABLE & MUJER \\
\hline $440 / 2012$ & ÁVILA & HOMICIDIO & CULPABLE & HOMBRE \\
\hline $1225 / 2012$ & BURGOS & ASESINATO-A & NO CULPABLE & HOMBRE \\
\hline $560 / 2012$ & PALENCIA & HOMICIDIO & CULPABLE & HOMBRE \\
\hline $28 / 2013$ & SEGOVIA & HOMICIDIO & CONFORMIDAD & HOMBRE \\
\hline $38 / 2013$ & SEGOVIA & HOMICIDIO & CULPABLE & MUJER \\
\hline $164 / 2013$ & ZAMORA & HOMICIDIO & CONFORMIDAD & HOMBRE \\
\hline $901 / 2013$ & LEÓN & ASESINATO-A & CULPABLE & HOMBRE \\
\hline $209 / 2013$ & SEGOVIA & ASESINATO-A & CULPABLE & HOMBRE \\
\hline $316 / 2013$ & SEGOVIA & HOMICIDIO & CONFORMIDAD & HOMBRE \\
\hline $1256 / 2013$ & VALLADOLID & HOMICIDIO-I & CULPABLE & MUJER \\
\hline $333 / 2013$ & ÁVILA & ASESINATO-A & CULPABLE & HOMBRE \\
\hline $42 / 2014$ & BURGOS & ASESINATO-A & CULPABLE & HOMBRE \\
\hline $227 / 2014$ & LEÓN & HOMICIDIO & CULPABLES & HOMBRES (2) \\
\hline $69 / 2014$ & ZAMORA & ASESINATO-A & CULPABLE & HOMBRE \\
\hline $58 / 2014$ & SORIA & HOMICIDIO & CULPABLE & HOMBRE \\
\hline $417 / 2014$ & ZAMORA & ASESINATO-A/E & CULPABLES & HOMBRES (2) \\
\hline $370 / 2014$ & LEÓN & HOMICIDIO & CULPABLE/NO CULPABLE & HOMBRE Y MUJER \\
\hline $544 / 2014$ & VALLADOLID & ASESINATO-A & CULPABLE & HOMBRE \\
\hline $453 / 2014$ & LEÓN & ASESINATO-A & CULPABLE & HOMBRE \\
\hline $1021 / 2014$ & VALLADOLID & ASESINATO-A & CULPABLE & HOMBRE \\
\hline $631 / 2014$ & BURGOS & ASESINATO-A & CULPABLE/NO CULPABLE & HOMBRES (2) \\
\hline $7 / 2014 *$ & LEÓN & HOMICIDIO & CULPABLE & HOMBRE \\
\hline $52 / 2015$ & LEÓN & ASESINATO-A & CULPABLE & HOMBRE \\
\hline $25 / 2015$ & LEÓN & HOMICIDIO & CULPABLE-ABSUELTO & HOMBRE \\
\hline $480 / 2015$ & \begin{tabular}{|l} 
VALLADOLID \\
\end{tabular} & HOMIC./ASES.-E & CULPABLE/ NO CULPABLE & HOMBRE \\
\hline $461 / 2015$ & VALLADOLID & ASESINATO-A & CONFORMIDAD & HOMBRE \\
\hline $636 / 2015$ & LEÓN & ASESINATO-A & CULPABLE & HOMBRE \\
\hline $686 / 2015$ & VALLADOLID & ASESINATO-A & CULPABLE & HOMBRE \\
\hline $142 / 2015$ & PALENCIA & HOMICIDIO & CULPABLE & MUJER \\
\hline $670 / 2015$ & LEÓN & HOMICIDIO & CULPABLE & HOMBRE \\
\hline $1055 / 2015$ & VALLADOLID & ASESINATO-E & CULPABLE & HOMBRE \\
\hline $5 / 2015 *$ & ZAMORA & ASESINATO-A/E & CULPABLES & HOMBRES (2) \\
\hline $455 / 2015$ & ZAMORA & ASESINATO-A & CULPABLE & HOMBRE \\
\hline $78 / 2016$ & PALENCIA & HOMICIDIO & CONFORMIDAD & MUJER \\
\hline $93 / 2016$ & LEÓN & ASESINATO-A & CULPABLES & MUJERES (3) \\
\hline
\end{tabular}




\begin{tabular}{|c|c|c|c|c|}
\hline $564 / 2016$ & LEÓN & ASESINATO-A & CULPABLE & HOMBRE \\
\hline $560 / 2016$ & ÁVILA & ASESINATO-A & CULPABLE & HOMBRE \\
\hline $\mathbf{5 0 / 2 0 1 7}$ & VALLADOLID & ASESINATO-A & CULPABLES & HOMBR. (2), MUJER \\
\hline $\mathbf{6 2 / 2 0 1 7}$ & LEÓN & ASESINATO-A & CULP. (4)/NO CULP (1). & HOMBR. (4), MUJER \\
\hline $\mathbf{3 7 3 / 2 0 1 7}$ & LEÓN & ASESINATO-A & CULPABLE & HOMBRE \\
\hline $1007 / 2017$ & LEÓN & ASESINATO-A & CULPABLE & HOMBRE \\
\hline $412 / 2017$ & SALAMANCA & ASESINATO-E & CULPABLE & HOMBRE \\
\hline $820 / 2017$ & BURGOS & ASESINATO-A & CONFORMIDAD & HOMBRE \\
\hline $1068 / 2017$ & LEÓN & HOMICIDIO & CULPABLE & HOMBRE \\
\hline $205 / 2017$ & SORIA & ASESINATO-A & CULPABLE & HOMBRE \\
\hline
\end{tabular}

*Las sentencias marcadas constan con el número de recurso al no haber podido localizar la resolución de la Audiencia pero sí la del Tribunal Superior de Justicia.

Tabla 03. Veredictos emitidos por el jurado en la Audiencia Provincial.

Por sexos, los jurados han declarado culpables a 138 hombres y a 23 mujeres, mientras que han emitido veredicto de inculpabilidad para 29 hombres y 3 mujeres.

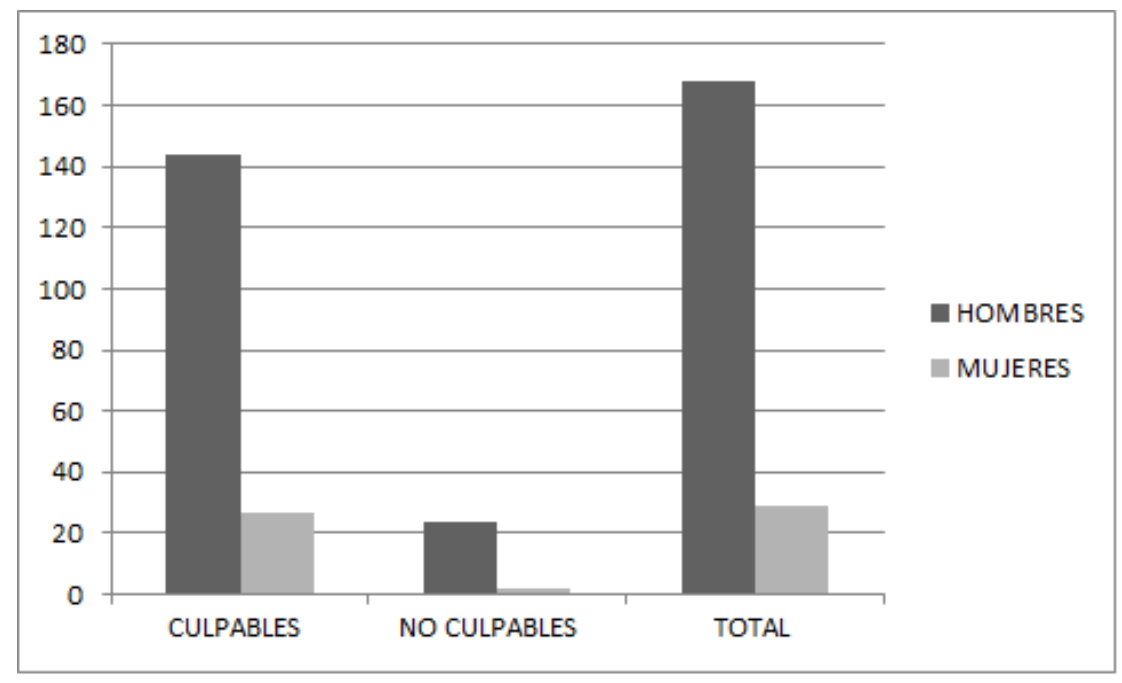

Gráfico 07: resultado de los veredictos separados por el sexo del acusado.

En lo que respecta a la segunda instancia, de las 193 resoluciones, tenemos constancia de que, al menos, 99 fueron recurridas en apelación ante el Tribunal Superior de Justicia de Castilla y León. A continuación se expone la tabla con los siguientes datos:

- La sentencia recurrida y su ámbito territorial.

- El delito juzgado: homicidio o asesinato. 
- El veredicto: culpable/no culpable.

- La Sentencia del Tribunal Superior de Justicia que ha resuelto la apelación.

- El fallo del Tribunal Superior de Justicia, si confirma o anula la Sentencia de la correspondiente Audiencia Provincial.

Señaladas en negrita las sentencias que se recurren posteriormente al Supremo.

\begin{tabular}{|c|c|c|c|c|}
\hline PROV./SAP & DELITO & VEREDICTO & STSJ & FALLO TSJ \\
\hline PA 7/1997 & HOMICIDIO & CULPABLE & $1348 / 1997$ & CONFIRMA \\
\hline SA 10/1997 & HOMICIDIO & CULPABLE & $387 / 1998$ & CONFIRMA \\
\hline BU 72/1997 & ASESINATO & ABSUELTO & $1021 / 1998$ & CONFIRMA \\
\hline VA 4/1998 & ASESINATO & CULPABLE & $1464 / 1998$ & CONFIRMA \\
\hline VA 3/1998 & ASESINATO & CULPABLE & $1599 / 1998$ & CONFIRMA \\
\hline SO 5/1998 & HOMICIDIO & NO CULPABLE & $2646 / 1998$ & ANULA \\
\hline ZA 163/1998 & HOMICIDIO & NO CULPABLES (2) & $3313 / 1998$ & CONFIRMA \\
\hline BU 8/1998 & HOMICIDIO & CULPABLE & $3691 / 1998$ & CONFIRMA \\
\hline LE 687/1998 & HOMICIDIO & CULPABLE & $3718 / 1998$ & CONFIRMA \\
\hline VA 9/1998 & ASESINATO & CULPABLE & $4607 / 1998$ & CONFIRMA \\
\hline LE 1261/1998 & HOMICIDIO & CULPABLE & $837 / 1999$ & CONFIRMA \\
\hline LE 1353/1998 & HOMICIDIO & CULPABLE & $499 / 1999$ & CONFIRMA \\
\hline SO 305/1998 & ASESINATO & CULPABLE/NO CULPABLE & $2418 / 1999$ & CONFIRMA \\
\hline AV 127/1999 & HOMICIDIO & CULPABLE & $4279 / 1999$ & CONFIRMA \\
\hline LE 374/1999 & HOMICIDIO & NO CULPABLE & $3344 / 1999$ & CONFIRMA \\
\hline VA 907/1999 & HOMICIDIO & CULPABLE & $3944 / 1999$ & CONFIRMA \\
\hline BU 733/1999 & ASESINATO & CULPABLE & $3977 / 1999$ & CONFIRMA \\
\hline VA 1090/1999 & ASESINATO & CULPABLE & $5304 / 1999$ & CONFIRMA \\
\hline LE 859/1999 & ASESINATO & CULPABLE & $3 / 2000$ & CONFIRMA \\
\hline LE 935/1999 & HOMICIDIO & CULPABLE & $1719 / 2000$ & CONFIRMA \\
\hline VA $263 / 2000$ & HOMIC./ASES. & CULPABLE & $3326 / 2000$ & CONFIRMA \\
\hline BU 491/2000 & ASESINATO & CULPABLE & $3621 / 2000$ & CONFIRMA \\
\hline BU 1099/2000 & HOMICIDIO & CULPABLE & $5892 / 2000$ & CONFIRMA \\
\hline BU $1157 / 2000$ & HOMICIDIO & CULPABLE & $6242 / 2000$ & CONFIRMA \\
\hline LE $1968 / 2000$ & ASESINATO & CULPABLE & $293 / 2001$ & CONFIRMA \\
\hline SG 442/2000 & ASESINATO & CULPABLE & $1358 / 2001$ & CONFIRMA \\
\hline BU 256/2001 & HOMICIDIO & CULPABLES (2) & $3474 / 2001$ & CONFIRMA \\
\hline P 198/2001 & ASESINATO & CULPABLE & $3685 / 2001$ & CONFIRMA \\
\hline VA 499/2001 & HOMICIDIO & CULPABLE & $4117 / 2001$ & CONFIRMA \\
\hline AV 204/2001 & ASESINATO & CULPABLE & $5399 / 2001$ & CONFIRMA \\
\hline BU 771/2002 & HOMICIDIO & CULPABLE & $4602 / 2002$ & CONFIRMA \\
\hline SG 244/2002 & ASESINATO & CULPABLE & $4895 / 2002$ & CONFIRMA \\
\hline ZA 373/2002 & HOMIC./ASES. & NO CULPABLE & $5805 / 2002$ & CONFIRMA \\
\hline
\end{tabular}




\begin{tabular}{|c|c|c|c|c|}
\hline LE 2089/2002 & ASESINATO & CULPABLE & $468 / 2003 *$ & CONFIRMA \\
\hline LE 1/2003 & ASESINATO & CULPABLE & $1176 / 2003$ & CONFIRMA \\
\hline SA 200/2003 & HOMICIDIO & CULPABLE & $324 / 2004^{*}$ & CONFIRMA \\
\hline VA $1545 / 2003$ & HOMICIDIO & CULPABLE & $598 / 2004$ & CONFIRMA \\
\hline LE 9/2003 & HOMICIDIO & CULPABLE & $721 / 2004$ & CONFIRMA \\
\hline SA 373/2004 & HOMICIDIO & CULPABLE & $5457 / 2004$ & CONFIRMA \\
\hline SG 4/2004 & ASESINATO & CULPABLES (2) & $521 / 2005$ & CONFIRMA \\
\hline BU 752/2004 & HOMICIDIO & CULPABLE & $2163 / 2005$ & CONFIRMA \\
\hline SA 760/2004 & HOMICIDIO & CULPABLES (3) & $2907 / 2005$ & CONFIRMA \\
\hline VA $1667 / 2005$ & ASESINATO & CULPABLE & $4468 / 2005$ & CONFIRMA \\
\hline SA $382 / 2005$ & HOMICIDIO & CULPABLE & $5792 / 2005$ & CONFIRMA \\
\hline LE 1098/2005 & HOMICIDIO & NO CULPABLES (2) & $76 / 2006$ & CONFIRMA \\
\hline SG 2/2005 & HOMICIDIO & CULPABLE & $10006 / 2006 *$ & CONFIRMA \\
\hline ZA 483/2005 & HOMICIDIO & CULPABLE & $6252 / 2006$ & CONFIRMA \\
\hline LE $1355 / 2005$ & ASESINATO & CULPABLE & $6346 / 2006$ & CONFIRMA \\
\hline BU 6/2006 & ASESINATO & CULPABLE & $6466 / 2006$ & CONFIRMA \\
\hline ZA 7/2006 & HOMICIDIO & CULPABLE & $6467 / 2006$ & CONFIRMA \\
\hline BU 10/2005 & ASESINATO & CULPABLE & $6253 / 2006$ & CONFIRMA \\
\hline LE 11/2005 & HOMICIDIO & NO CULPABLES (2) & $6254 / 2006$ & CONFIRMA \\
\hline BU 151/2006 & ASESINATO & ABSOLUCIÓN & $6256 / 2006$ & CONFIRMA \\
\hline SO 5/2006 & HOMICIDIO & CULPABLE & $6275 / 2006$ & CONFIRMA \\
\hline BU 9/2006 & HOMICIDIO & CULPABLE & $320 / 2007$ & CONFIRMA \\
\hline LE 2/2007 & ASESINATO & CULPABLE & $3357 / 2007$ & CONFIRMA \\
\hline LE 1339/2007 & ASESINATO & CULPABLE & $7074 / 2007$ & CONFIRMA \\
\hline BU 1171/2007 & HOMICIDIO & CULPABLE & $7 / 2008$ & CONFIRMA \\
\hline BU 1174/2007 & HOMICIDIO & CULPABLE & $2356 / 2008$ & CONFIRMA \\
\hline SG 2/2008 & ASESINATO & NO CULPABLE & $4932 / 2008$ & CONFIRMA \\
\hline P 472/2008 & ASESINATO & CULPABLES (2) & $6690 / 2008$ & CONFIRMA \\
\hline SG 255/2008 & HOMICIDIO & CULPABLE & $786 / 2009$ & CONFIRMA \\
\hline AV 65/2009 & ASESINATO & CULPABLE & $4692 / 2009$ & CONFIRMA \\
\hline VA 1480/2009 & ASESINATO & CULPABLE & $3806 / 2009$ & CONFIRMA \\
\hline VA $1476 / 2009$ & ASESINATO & CULPABLE & $6912 / 2009$ & CONFIRMA \\
\hline VA $1239 / 2009$ & ASESINATO & CULPABLE & $371 / 2010$ & CONFIRMA \\
\hline BU $1238 / 2009$ & HOMICIDIO & CULPABLE & $3201 / 2010$ & CONFIRMA \\
\hline VA $669 / 2010$ & HOMICIDIO & CULPABLE & $4859 / 2010$ & CONFIRMA \\
\hline BU $1292 / 2010$ & HOMICIDIO & CULPABLE & $683 / 2011$ & CONFIRMA \\
\hline ZA 406/2010 & HOMICIDIO & CULPABLE & $1220 / 2011$ & CONFIRMA \\
\hline VA $1563 / 2010$ & HOMICIDIO & ABSOLUCIÓN & $1222 / 2011$ & CONFIRMA \\
\hline SA 622/2010 & ASESINATO & CULPABLE & $1221 / 2011$ & CONFIRMA \\
\hline P 559/2010 & ASESINATO & CULPABLE-ABSOLUCIÓN & $1935 / 2011$ & CONFIRMA \\
\hline VA $246 / 2011$ & HOMICIDIO & CULPABLE & $2721 / 2011$ & CONFIRMA \\
\hline SA 364/2011 & HOMICIDIO & CULPABLE & $4566 / 2011$ & CONFIRMA \\
\hline BU 809/2011 & ASESINATO & CULPABLE & $6487 / 2011$ & CONFIRMA \\
\hline ZA 540/2011 & ASESINATO & CULPABLE & $1752 / 2012$ & CONFIRMA \\
\hline BU 1153/2011 & ASESINATO & CULPABLE & $2174 / 2012$ & CONFIRMA \\
\hline BU 89/2012 & HOMICIDIO & CULPABLES (3) & $3682 / 2012$ & CONFIRMA \\
\hline BU 7/2012 & ASESINATO & CULPABLE & $4844 / 2012$ & CONFIRMA \\
\hline
\end{tabular}




\begin{tabular}{|c|c|c|c|c|}
\hline BU 851/2012 & ASESINATO & CULPABLE & $5612 / 2012$ & CONFIRMA \\
\hline SO 233/2012 & ASESINATO & CULPABLE & $\mathbf{2 6 0 / 2 0 1 3}$ & CONFIRMA \\
\hline AV 440/2012 & HOMICIDIO & CULPABLE & $\mathbf{9 1 / 2 0 1 3}$ & CONFIRMA \\
\hline P 560/2012 & HOMICIDIO & CULPABLE & $2671 / 2013$ & CONFIRMA \\
\hline AV 333/2013 & ASESINATO & CULPABLE & $1391 / 2014$ & ANULA \\
\hline BU 42/2014 & ASESINATO & CULPABLE & $2423 / 2014$ & CONFIRMA \\
\hline LE 370/2014 & HOMICIDIO & CULPABLE & $\mathbf{6 1 9 4 / 2 0 1 4}$ & CONFIRMA \\
\hline VA 544/2014 & ASESINATO & CULPABLE & $\mathbf{3 9 7 3 / 2 0 1 4}$ & CONFIRMA \\
\hline VA 1021/2014 & ASESINATO & CULPABLE & $410 / 2015$ & CONFIRMA \\
\hline BU 631/2014 & ASESINATO & CULPABLE/NO CULPABLE & $\mathbf{1 7 5 2 / 2 0 1 5}$ & CONFIRMA \\
\hline LE 7/2014 & HOMICIDIO & CULPABLE & $\mathbf{3 4 2 3 / 2 0 1 5}$ & CONFIRMA \\
\hline VA 480/2015 & HOMIC./ASES. & CULPABLE/NO CULPABLE & $3646 / 2015$ & CONFIRMA \\
\hline VA 686/2015 & ASESINATO & CULPABLE & $4643 / 2015$ & CONFIRMA \\
\hline ZA 5/2015 & ASESINATO & CULPABLES (2) & $\mathbf{5 0 4 7 / 2 0 1 5}$ & CONFIRMA \\
\hline ZA 455/2015 & ASESINATO & CULPABLE & $1438 / 2016$ & CONFIRMA \\
\hline LE 93/2016 & ASESINATO & CULPABLES (3) & $\mathbf{1 9 0 6 / 2 0 1 6}$ & CONFIRMA \\
\hline VA 50/2017 & ASESINATO & CULPABLES (3) & $2366 / 2017$ & 2 CONFIR./ANULA \\
\hline LE 62/2017 & ASESINATO & CULPABLES (3) & $3396 / 2017$ & CONFIR./ANULA 2 \\
\hline LE 373/2017 & ASESINATO & CULPABLE & $3118 / 2017$ & CONFIRMA \\
\hline
\end{tabular}

*Las sentencias marcadas constan con el número de recurso al no haber podido localizar la resolución del Tribunal Superior Justicia pero sí la del Tribunal Supremo.

Tabla 04. Sentencias dictadas por el TSJ en apelación.

En este punto debemos destacar una circunstancia importante. Al indicar en la tabla que la sentencia del Tribunal Superior de Justicia confirma, nos referimos exclusivamente a los factores que afectan al veredicto de culpabilidad o inculpabilidad del jurado, que es el objeto de esta tesis. Hay numerosos recursos que sí han revocado parcialmente la sentencia pero en otros aspectos, como la responsabilidad civil, modificar la calificación de homicidio a asesinato o viceversa, declarar un homicidio como imprudente o no, modificar la pena a más grave o más leve, cambio en alguna circunstancia modificativa de la responsabilidad criminal, etc., pero esa no es función del jurado y, por ese motivo, aunque en parte anulen la sentencia de la Audiencia Provincial, se han considerado como confirmación al desestimar el recurso en lo que afecta exclusivamente al veredicto. 
Respecto a la modificación del veredicto del jurado por parte del Tribunal Superior de Justicia, el resultado es el siguiente:

- 92 de las sentencias confirman el veredicto emitido en la primera instancia, repartido de la siguiente manera:

- 82 confirman la culpabilidad. En 9 de ellas hay varios acusados y se confirma la culpabilidad de todos. Y en 1 se juzga por ambos tipos, por lo que son 96 veredictos de culpabilidad confirmados por el TSJ.

- 6 confirman la no culpabilidad. En 3 de ellas hay dos acusados y en 1 son enjuiciados los dos delitos, por lo tanto son 10 veredictos confirmados de inculpabilidad.

- En 4 existen ambos veredictos porque hay varios acusados o se juzgan los dos tipos delictivos y se confirman tanto los de culpabilidad (4) como los de inculpabilidad (4).

- Únicamente en 2 de los casos no confirma la sentencia de la Audiencia Provincial y revoca un veredicto de culpabilidad y uno de inculpabilidad:

- En la SAP SO 5/1998 el jurado declaró culpables a los dos acusados de un delito de lesiones y no culpables de homicidio. Solamente se recurre una de las dos condenas. El TSJ desestima parcialmente el recurso y absuelve al acusado del delito de lesiones pero lo condena por homicidio imprudente. El veredicto se señala en singular porque el recurso solo afecta a uno de los encausados.

- El veredicto de culpabilidad revocado fue por asesinato y la condena impuesta era de nueve años. El TSJ absuelve al recurrente. (SAP AV 333/2013). 
- Hay otras 2 sentencias en las que se confirman unos veredictos y se revocan otros ya que hay varios acusados:

- SAP VA 50/2017: con tres recurrentes, dos condenados como autores de asesinato y una mujer como cómplice, el TSJ confirma las condenas de los dos hombres y anula la de la mujer, a la que absuelve de toda responsabilidad penal.

- SAP LE 62/2017. Aquí hubo cuatro acusados y un absuelto. Recurren tres de los acusados porque el otro falleció y por tanto quedó extinguida la acción penal. De esos tres, únicamente se confirma una de las condenas y se absuelve a los otros dos.

Además se han confirmado las tres absoluciones recurridas en las que no hubo veredicto del jurado.

Es decir, que el total de fallos del Tribunal Superior de Justicia de Castilla y León es la confirmación de 117 veredictos (103 de culpabilidad y 14 de inculpabilidad). Y revoca 5 (4 veredictos de culpabilidad y uno de inculpabilidad).

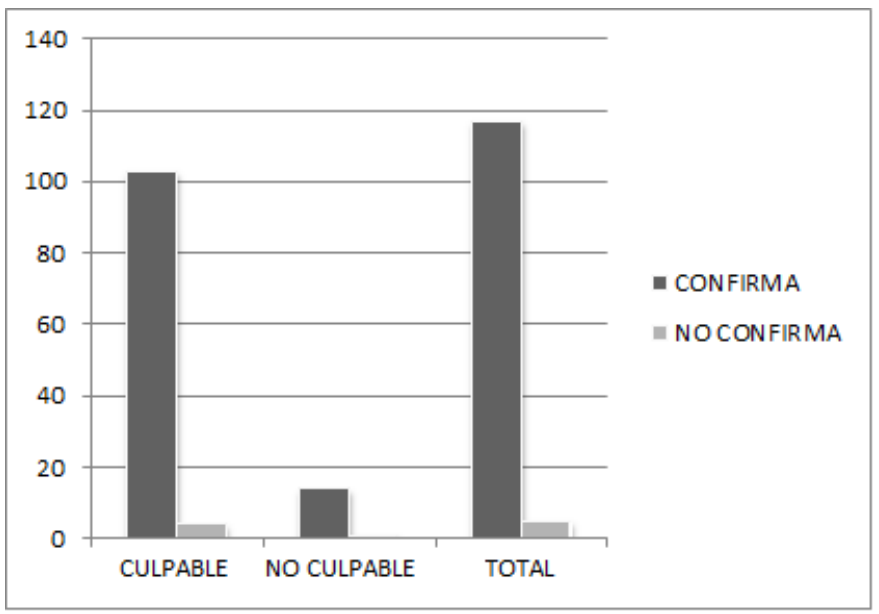

Gráfico 08: sentencias del Tribunal Superior de Justicia en apelación. 
De las 99 sentencias en apelación del Tribunal Superior de Justicia, al menos, 38 han sido recurridas en casación ante el Tribunal Supremo. La siguiente tabla muestra esos 38 recursos con estos datos:

- La sentencia original de la Audiencia Provincial recurrida y su ámbito territorial.

- El veredicto del jurado: culpable/no culpable.

- La Sentencia del Tribunal Superior de Justicia que ha resuelto la apelación.

- El fallo del TSJ, si confirma o anula la Sentencia de la correspondiente Audiencia Provincial.

- La Sentencia del Tribunal Supremo que ha resuelto el recurso de casación.

- El fallo del Supremo, si confirma o casa la sentencia, bien de la Audiencia Provincial o bien del Tribunal Superior de Justicia. 


\begin{tabular}{|c|c|c|c|c|c|}
\hline PROV./SAP & VEREDICTO & STSJ & FALLO TSJ & STS & FALLO TS \\
\hline PA $7 / 1997$ & CULPABLE & $1348 / 1997$ & CONFIRMA & $1443 / 1999$ & CONFIRMA \\
\hline VA 4/1998 & CULPABLE & $1464 / 1998$ & CONFIRMA & $3028 / 1999$ & CONFIRMA \\
\hline VA 3/1998 & CULPABLE & $1599 / 1998$ & CONFIRMA & $1760 / 1999$ & CONFIRMA \\
\hline ZA 163/1998 & NO CULPABLES & $3313 / 1998$ & CONFIRMA & $1311 / 00-6892 / 05$ & ANULA \\
\hline BU 8/1998 & CULPABLE & $3691 / 1998$ & CONFIRMA & $6214 / 1999$ & CONFIRMA \\
\hline LE 1353/1998 & CULPABLE & $499 / 1999$ & CONFIRMA & $6237 / 2000$ & CONFIRMA \\
\hline LE 1261/1998 & CULPABLE & $837 / 1999$ & CONFIRMA & $3414 / 2000$ & CONFIRMA \\
\hline AV 127/1999 & CULPABLE & $4279 / 1999$ & CONFIRMA & $4636 / 2001$ & CONFIRMA \\
\hline LE 859/1999 & CULPABLE & $3 / 2000$ & CONFIRMA & $9719 / 2000$ & CONFIRMA \\
\hline VA 263/2000 & CULPABLE & $3326 / 2000$ & CONFIRMA & $7925 / 2001$ & CONFIRMA \\
\hline SG 442/2000 & CULPABLE & $1358 / 2000$ & CONFIRMA & $3013 / 2002$ & CONFIRMA \\
\hline AV 204/2001 & CULPABLES & $5399 / 2001$ & CONFIRMA & $5829 / 2002$ & CONFIRMA \\
\hline SG 244/2002 & CULPABLE & $4895 / 2002$ & CONFIRMA & $3753 / 2002$ & CONFIRMA \\
\hline ZA 373/2002 & NO CULPABLE & $5805 / 2002$ & CONFIRMA & $6884 / 2003$ & CONFIRMA \\
\hline LE 2089/2002 & CULPABLE & $468 / 2003$ & CONFIRMA & $8432 / 2003$ & CONFIRMA \\
\hline LE $1 / 2003$ & CULPABLE & $1176 / 2003$ & CONFIRMA & $3741 / 2004$ & CONFIRMA \\
\hline VA $1545 / 2003$ & CULPABLE & $598 / 2004$ & CONFIRMA & $6279 / 2004$ & CONFIRMA \\
\hline LE 9/2003 & CULPABLE & $721 / 2004$ & CONFIRMA & $6474 / 2004$ & CONFIRMA \\
\hline SA $200 / 2003$ & CULPABLE & $324 / 2004$ & CONFIRMA & $2670 / 2005$ & CONFIRMA \\
\hline SG 4/2004 & CULPABLES & $521 / 2005$ & CONFIRMA & $7739 / 2005$ & CONFIRMA \\
\hline SG 2/2005 & CULPABLE & $10006 / 2006$ & CONFIRMA & $3009 / 2009$ & CONFIRMA \\
\hline LE $1098 / 2005$ & NO CULPABLES & $76 / 2006$ & CONFIRMA & $410 / 2007$ & CONFIRMA \\
\hline SG 2/2008 & NO CULPABLE & $4932 / 2008$ & CONFIRMA & $3092 / 2009$ & CONFIRMA \\
\hline $\mathrm{P} 472 / 2008$ & CULPABLES & $6990 / 2008$ & CONFIRMA & $753 / 2010$ & CONFIRMA \\
\hline VA $1480 / 2009$ & CULPABLE & $3806 / 2009$ & CONFIRMA & $760 / 2010$ & CONFIRMA \\
\hline AV 65/2009 & CULPABLE & $4692 / 2009$ & CONFIRMA & $3684 / 2010$ & ANULA \\
\hline SA $622 / 2010$ & CULPABLE & $1221 / 2011$ & CONFIRMA & $9143 / 2011$ & CONFIRMA \\
\hline P 559/2010 & CULPABLE-ABS. & $1935 / 2011$ & CONFIRMA & $1954 / 2012$ & CONFIRMA \\
\hline SA 364/2011 & CULPABLE & $4566 / 2011$ & CONFIRMA & $6335 / 2012$ & CONFIRMA \\
\hline BU 1153/2011 & CULPABLE & $2174 / 2012$ & CONFIRMA & $4654 / 2012$ & CONFIRMA \\
\hline SO 233/2012 & CULPABLE & $260 / 2013$ & CONFIRMA & $5100 / 2013$ & CONFIRMA \\
\hline AV 440/2012 & CULPABLE & $91 / 2013$ & CONFIRMA & $5316 / 2013$ & CONFIRMA \\
\hline VA 544/2014 & CULPABLE & $3973 / 2014$ & CONFIRMA & $1526 / 2015$ & CONFIRMA \\
\hline LE 370/2014 & CULP./NO CULP. & $6194 / 2014$ & CONFIRMA & $2461 / 2015$ & CONFIRMA \\
\hline BU 631/2014 & CULP./NO CULP. & $1752 / 2015$ & CONFIRMA & $5074 / 2015$ & CONFIRMA \\
\hline LE 7/2014 & CULPABLE & $3423 / 2015$ & CONFIRMA & $1490 / 2016$ & CONFIRMA \\
\hline ZA 5/2015 & CULPABLES & $5047 / 2015$ & CONFIRMA & $2940 / 2016$ & CONFIRMA \\
\hline LE 93/2016 & CULPABLES & $1906 / 2016$ & CONFIRMA & $5521 / 2016$ & CONFIRMA \\
\hline
\end{tabular}

Tabla 05. Sentencias dictadas por el TS en casación. 
Podemos observar que de esos treinta y ocho recursos, solo en dos ocasiones el Tribunal Supremo anula las sentencias.

En el primero de ellos existen dos sentencias del Supremo. La SAP 163/1998, de 25 de marzo, donde el veredicto fue de inculpabilidad para los dos acusados por homicidio, se recurre al Tribunal Superior de Justicia, que confirma el fallo de la Audiencia y por lo tanto el veredicto del jurado, en la STSJ 3313/1998, de 9 de julio. Posteriormente, la STS 1311/2000, de 21 de febrero, casa la STSJ y ordena que se celebre un nuevo juicio en la Audiencia Provincial de Zamora. Pero el Supremo dicta una nueva resolución porque, tras la anterior, se recurrió ante el Tribunal Constitucional, en el recurso de amparo 2010/2000, que otorgó el amparo alegado por uno de los recurrentes sobre el derecho a la tutela judicial efectiva sin indefensión, por lo que el Tribunal Supremo tuvo que pronunciarse de nuevo sobre este asunto en la STS 6892/2005, de 10 de noviembre, en la que acoge un motivo más por quebrantamiento de forma y vuelve a ordenar que se repita el juicio en la Audiencia Provincial. Es decir, que precisamente el Supremo anula la sentencia que se dictó como consecuencia de dos veredictos de inculpabilidad.

En el segundo de los supuestos de casación, se absuelve a un condenado por asesinato alevoso, que había sido condenado por la Audiencia Provincial de Ávila a diecisiete años y medio de prisión, extremo confirmado íntegramente por el Tribunal Superior de Justicia.

Por lo tanto son 36 recursos en los que se confirman 45 veredictos (38 de culpabilidad y 7 de inculpabilidad) y 2 sentencias que casan un veredicto de culpabilidad y 2 de inculpabilidad. 


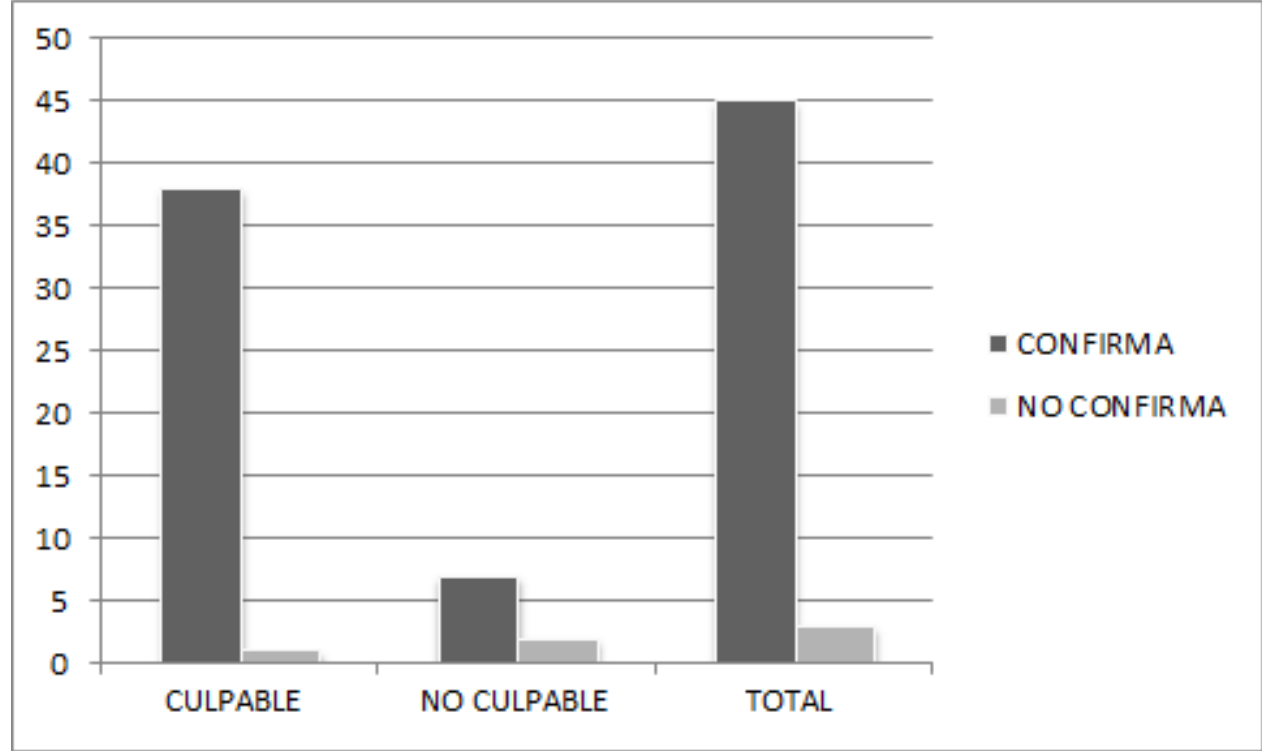

Gráfico 09: sentencias del Tribunal Supremo en casación. 


\section{RESULTADOS Y DISCUSIÓN.}

\subsection{Descripción de las variables y los resultados de la investigación.}

El objetivo de la tesis es comprobar:

- por una parte, si los jurados tienden a emitir más veredictos de culpabilidad o de inculpabilidad a la hora de juzgar los delitos de homicidio y de asesinato y,

- por otra, explorar si son o no más severos en sus veredictos que los jueces profesionales en sus fallos.

Partiendo de este planteamiento y, tras exponer los datos del número de sentencias y sus respectivos veredictos así como de los recursos, en este apartado haremos el análisis estadístico descriptivo según las variables de la base de datos creada con el objeto de obtener los resultados. Para ello se ha utilizado el programa SPSS (Statistical Pakcage for the Social Sciences, paquete estadístico para ciencias sociales).

Cada una de las circunstancias que tenemos en cuenta para la investigación es la denominada variable (delito, veredicto, sexo, recurso, etc.) $y$, la clasificación de cada una de esas variables son las "modalidades", que se numeran como "valores" (por ejemplo, en la variable delito, el "valor 1" es el homicidio y el "valor 2" el asesinato).

Antes de pasar a la explicación de los datos concretos, debemos aclarar algunos puntos que influyen en los resultados:

- No disponemos del $100 \%$ de las sentencias dictadas durante los veinticuatro años que lleva en vigor la LOTJ, al no estar algunas disponibles a través del CENDOJ ni de otras bases de datos jurídicas consultadas, pero sí hallamos una muestra 
bastante significativa adecuadamente repartida por provincias y por fechas.

- El periodo de cierre elegido ha sido el 31 de diciembre de 2017, por lo tanto, puede haber sentencias que se hayan recurrido posteriormente, que sin embargo aquí figuren como no recurridas y como tales las hemos considerado.

- Para el análisis estadístico no tenemos en cuenta el número de sentencias sino el de veredictos, bien porque haya varios acusados en un mismo proceso o porque una persona haya sido procesada por más de un delito. Hay que añadir, que en algunos de los juicios en los que han existido varios veredictos, no se han recurrido todos, lo que motiva que para ser más precisos con los resultados, se tengan en cuenta de manera individual.

6.1.1. Resultados respecto a los veredictos emitidos por el jurado en las Audiencias Provinciales.

En primer lugar hemos tomado la muestra representativa de las 193 Sentencias de las Audiencias Provinciales, a las que les corresponde un total de 235 veredictos, con las siguientes variables:

- Tipo de delito: con las modalidades:

- Valor 1: homicidio, a su vez, clasificado en doloso o por imprudencia.

- Valor 2: asesinato, a su vez, clasificado en función de las cuatro características que califican dicho tipo agravado: alevosía; precio, recompensa o promesa; ensañamiento; para facilitar la comisión de otro delito o para evitar que se 
descubra; y también cuando se dan juntas más de una de estas circunstancias.

- Veredicto, que incluye no solo los veredictos de los jurados sino todos los fallos de las sentencias, con las modalidades:

- Valor 1: culpable.

- Valor 2: no culpable.

- Valor 3: sentencia de conformidad.

- Valor 4: absolución por otro motivo.

- Sexo de la persona enjuiciada, con las modalidades:

- Valor 1: hombre.

- Valor 2: mujer.

- Primer recurso al TSJ, con las modalidades:

- Valor 1: recurrido.

- Valor 2: no recurrido.

Examinamos cada una de las variables por separado y también la combinación de algunas de ellas. Las tablas que se muestran a continuación expresan:

- La frecuencia, que es el número de veredictos analizados.

- Los porcentajes con los que se corresponden.

También se presentan los gráficos que describen dichas cantidades. Los resultados estadísticos obtenidos del análisis son los siguientes:

6.1.1.1. Variables analizadas de manera independiente.

1. Para la variable delito.

De los 235 veredictos, 118 son de homicidio (50’20\%) y 117 de asesinato (49'80\%), casi igualados: 


\section{Estadísticos}

\section{Delito}

\begin{tabular}{|c|c|c|}
\hline $\mathrm{N}$ & Válido & 235 \\
\hline & Perdidos & 0 \\
\hline
\end{tabular}

\section{Delito}

\begin{tabular}{|c|c|c|c|c|c|}
\hline & & Frecuencia & Porcentaje & Porcentaje válido & $\begin{array}{l}\text { Porcentaje } \\
\text { acumulado }\end{array}$ \\
\hline Válido & Homicidio & 118 & 50,2 & 50,2 & 50,2 \\
\hline & Asesinato & 117 & 49,8 & 49,8 & 100,0 \\
\hline & Total & 235 & 100,0 & 100,0 & \\
\hline
\end{tabular}

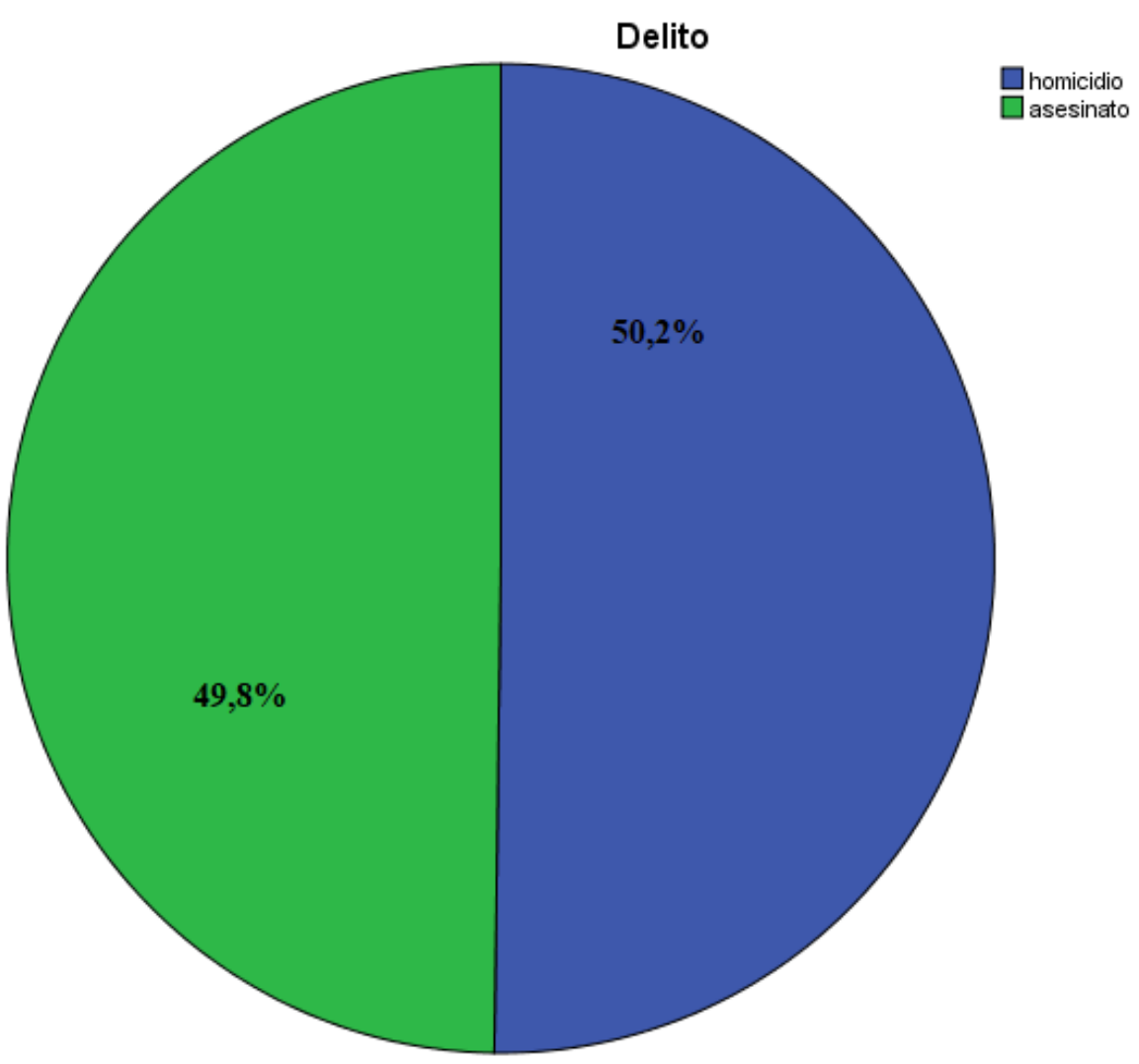

Gráfico 10: porcentajes para la variable delito. 
- Observamos primero los 118 homicidios y, dentro de su clasificación, casi todos son dolosos, 99 (83'9\%), mientras que solamente 19 han sido cometidos por imprudencia (16'1\%).

\section{Estadísticos}

Homicidio

\begin{tabular}{|c|c|c|}
\hline $\mathrm{N}$ & Válido & 118 \\
\hline & Perdidos & 0 \\
\hline
\end{tabular}

Homicidio

\begin{tabular}{|l|r|r|r|r|}
\hline & Frecuencia & Porcentaje & Porcentaje válido & $\begin{array}{r}\text { Porcentaje } \\
\text { acumulado }\end{array}$ \\
\hline Válido Doloso & 99 & 83,9 & 83,9 & 83,9 \\
& 19 & 16,1 & 16,1 & 100,0 \\
imprudente & 118 & 100,0 & 100,0 & \\
\hline
\end{tabular}

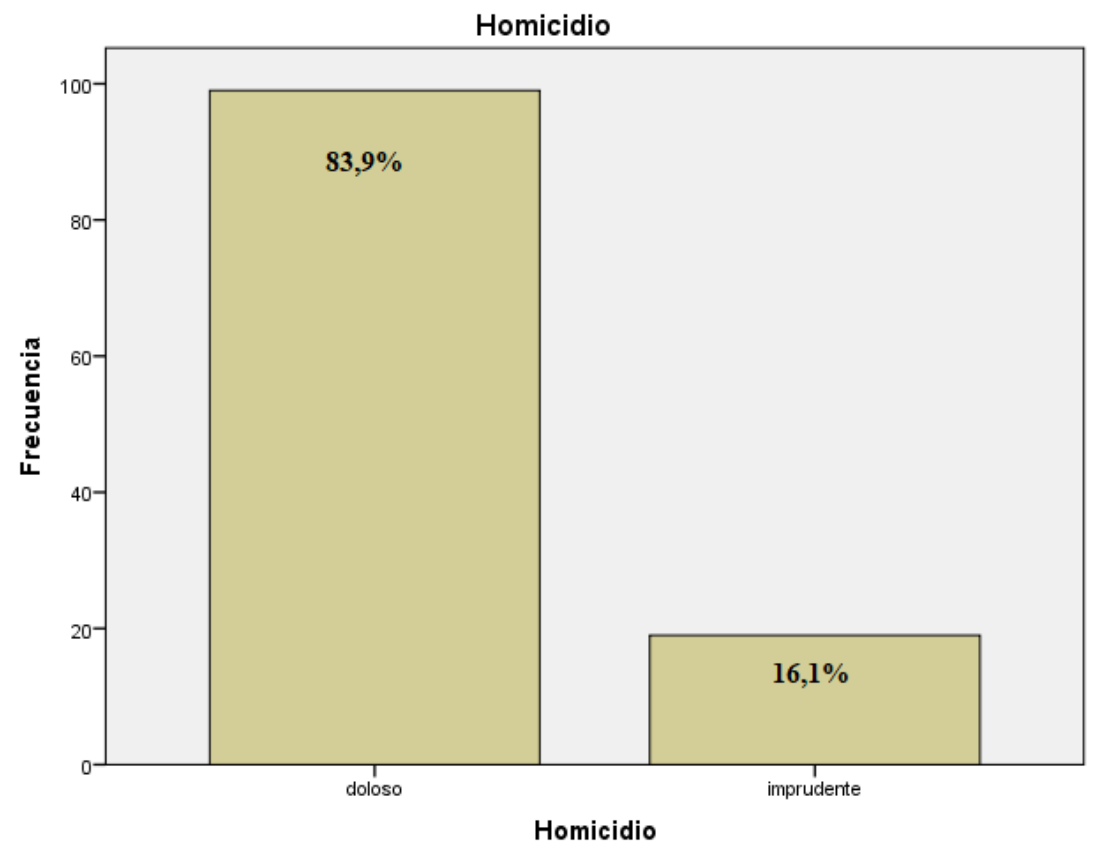

Gráfico 11: porcentajes para el valor homicidio. 
- Si repasamos los veredictos por tipo de homicidio, existe mayor porcentaje de veredictos de culpabilidad en el homicidio imprudente, 15 de 19 (78'9\% de los imprudentes) que en el doloso, 60 de 99 (60'6\% de los dolosos).

- Llama la atención la diferencia en las sentencias de conformidad ya que, de las 22 , solo se llega a 1 en un homicidio por imprudencia, donde no hubo jurado, mientras que las otras 21 son en el homicidio doloso. Eso es lo que hace que apenas haya distancia entre el porcentaje de veredictos de inculpabilidad, 17 en el doloso (17'2\%) por 3 del imprudente $\left(15^{\prime} 8 \%\right)$.

Resumen de procesamiento de casos

\begin{tabular}{|c|c|c|c|c|c|c|}
\hline & \multicolumn{6}{|c|}{ Casos } \\
\hline & \multicolumn{2}{|c|}{ Válidos } & \multicolumn{2}{|c|}{ Perdidos } & \multicolumn{2}{|c|}{ Total } \\
\hline & $\mathrm{N}$ & Porcentaje & $\mathrm{N}$ & Porcentaje & $\mathrm{N}$ & Porcentaje \\
\hline Homicidio $*$ Veredicto AP & 118 & $100,0 \%$ & 0 & $0,0 \%$ & 118 & $100,0 \%$ \\
\hline
\end{tabular}


Tabla cruzada Homicidio*Veredicto AP

\begin{tabular}{|c|c|c|c|c|c|c|c|}
\hline & & & \multicolumn{3}{|c|}{ Veredicto AP } & \multirow[b]{2}{*}{ absolu. } & \multirow[b]{2}{*}{ Total } \\
\hline & & & culpable & no culpable & $\mathrm{sc}$ & & \\
\hline \multirow[t]{8}{*}{ Homicidio } & Doloso & Recuento & 60 & 17 & 21 & 1 & 99 \\
\hline & & $\%$ dentro de Homicidio & $60,6 \%$ & $17,2 \%$ & $21,2 \%$ & $1,0 \%$ & $100,0 \%$ \\
\hline & & $\begin{array}{l}\% \text { dentro de Veredicto } \\
\text { AP }\end{array}$ & $80,0 \%$ & $85,0 \%$ & $95,5 \%$ & $100,0 \%$ & $83,9 \%$ \\
\hline & & $\%$ del total & $50,8 \%$ & $14,4 \%$ & $17,8 \%$ & $0,8 \%$ & $83,9 \%$ \\
\hline & \multirow[t]{4}{*}{ imprudente } & Recuento & 15 & 3 & 1 & 0 & 19 \\
\hline & & $\%$ dentro de Homicidio & $78,9 \%$ & $15,8 \%$ & $5,3 \%$ & $0,0 \%$ & $100,0 \%$ \\
\hline & & $\begin{array}{l}\% \text { dentro de Veredicto } \\
\text { AP }\end{array}$ & $20,0 \%$ & $15,0 \%$ & $4,5 \%$ & $0,0 \%$ & $16,1 \%$ \\
\hline & & $\%$ del total & $12,7 \%$ & $2,5 \%$ & $0,8 \%$ & $0,0 \%$ & $16,1 \%$ \\
\hline \multirow[t]{4}{*}{ Total } & & Recuento & 75 & 20 & 22 & 1 & 118 \\
\hline & & $\%$ dentro de Homicidio & $63,6 \%$ & $16,9 \%$ & $18,6 \%$ & $0,8 \%$ & $100,0 \%$ \\
\hline & & $\begin{array}{l}\% \text { dentro de Veredicto } \\
\text { AP }\end{array}$ & $100,0 \%$ & $100,0 \%$ & $100,0 \%$ & $100,0 \%$ & $100,0 \%$ \\
\hline & & $\%$ del total & $63,6 \%$ & $16,9 \%$ & $18,6 \%$ & $0,8 \%$ & $100,0 \%$ \\
\hline
\end{tabular}




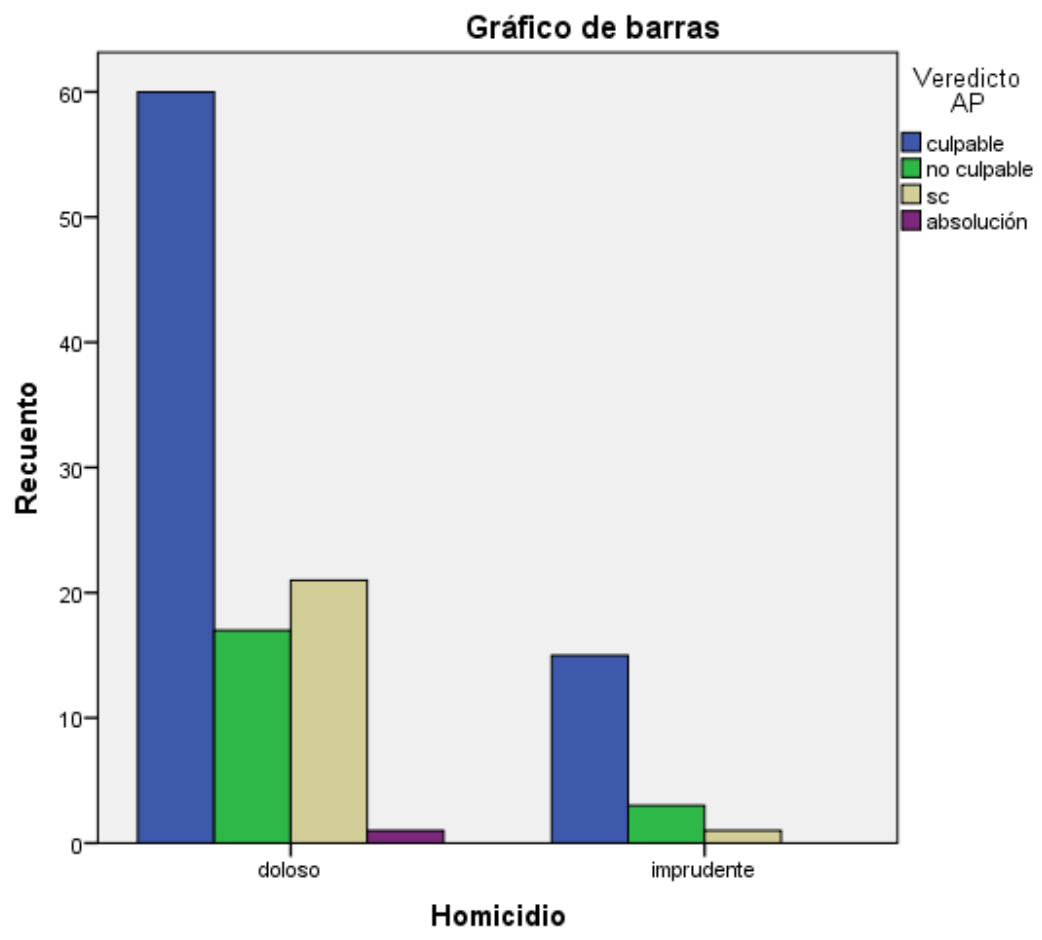

Gráfico 12: veredictos del jurado en los homicidios.

- Por último, si nos fijamos en los recursos de apelación al TSJCyL, vemos que es mayor el porcentaje de recursos en los homicidios imprudentes (63'2\%), que en los no imprudentes (46 5\%), posiblemente debido al gran número de sentencias de conformidad dictadas en los casos de homicidios dolosos.

Resumen de procesamiento de casos

\begin{tabular}{|c|c|c|c|c|c|c|}
\hline & \multicolumn{6}{|c|}{ Casos } \\
\hline & \multicolumn{2}{|c|}{ Válidos } & \multicolumn{2}{|c|}{ Perdidos } & \multicolumn{2}{|c|}{ Total } \\
\hline & $\mathrm{N}$ & Porcentaje & $\mathrm{N}$ & Porcentaje & $\mathrm{N}$ & Porcentaje \\
\hline Homicidio * Apelación TSJ & 118 & $100,0 \%$ & 0 & $0,0 \%$ & 118 & $100,0 \%$ \\
\hline
\end{tabular}


Tabla cruzada Homicidio*Apelación TSJ

\begin{tabular}{|c|c|c|c|c|c|}
\hline & & & \multicolumn{2}{|c|}{ Apelación TSJ } & \multirow[b]{2}{*}{ Total } \\
\hline & & & Recurrido & no recurrido & \\
\hline \multirow[t]{8}{*}{ Homicidio } & Doloso & Recuento & 46 & 53 & 99 \\
\hline & & $\%$ dentro de Homicidio & $46,5 \%$ & $53,5 \%$ & $100,0 \%$ \\
\hline & & $\%$ dentro de Apelación TSJ & $79,3 \%$ & $88,3 \%$ & $83,9 \%$ \\
\hline & & $\%$ del total & $39,0 \%$ & $44,9 \%$ & $83,9 \%$ \\
\hline & imprudente & Recuento & 12 & 7 & 19 \\
\hline & & $\%$ dentro de Homicidio & $63,2 \%$ & $36,8 \%$ & $100,0 \%$ \\
\hline & & $\%$ dentro de Apelación TSJ & $20,7 \%$ & $11,7 \%$ & $16,1 \%$ \\
\hline & & $\%$ del total & $10,2 \%$ & $5,9 \%$ & $16,1 \%$ \\
\hline \multirow[t]{4}{*}{ Total } & & Recuento & 58 & 60 & 118 \\
\hline & & $\%$ dentro de Homicidio & $49,2 \%$ & $50,8 \%$ & $100,0 \%$ \\
\hline & & $\%$ dentro de Apelación TSJ & $100,0 \%$ & $100,0 \%$ & $100,0 \%$ \\
\hline & & $\%$ del total & $49,2 \%$ & $50,8 \%$ & $100,0 \%$ \\
\hline
\end{tabular}

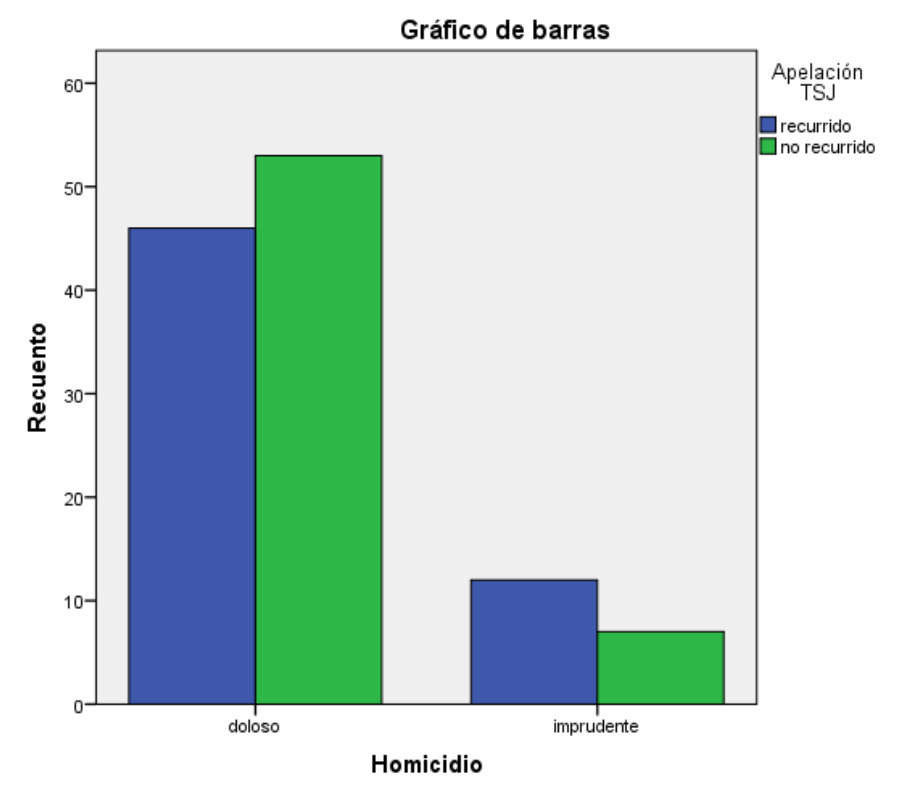

Gráfico 13: homicidios recurridos en apelación al TSJ. 
- Pasamos ahora a analizar los 117 asesinatos y las circunstancias que los califican. La gran mayoría, 100, son cometidos con alevosía $\left(85^{\prime} 5 \%\right.$ ), ninguno exclusivamente por precio, recompensa o promesa, 5 con ensañamiento (4'3\%), en 9 concurren alevosía y ensañamiento $\left(7^{\prime} 7 \%\right)$ y en 3 veredictos hay alevosía junto con la circunstancia de precio (2'6\%), los 3 pertenecientes al mismo caso.

Estadísticos

Asesinato

\begin{tabular}{|ll|r|}
\hline N & Válido & 117 \\
& Perdidos & 0 \\
\hline
\end{tabular}

Asesinato

\begin{tabular}{|l|r|r|r|r|}
\hline & Frecuencia & Porcentaje & Porcentaje válido & $\begin{array}{c}\text { Porcentaje } \\
\text { acumulado }\end{array}$ \\
\hline Válido Alevosía & 100 & 85,5 & 85,5 & 85,5 \\
ensañamiento & 5 & 4,3 & 4,3 & 89,7 \\
alev-ens & 9 & 7,7 & 7,7 & 97,4 \\
alev-prec & 3 & 2,6 & 2,6 & 100,0 \\
Total & 117 & 100,0 & 100,0 & \\
\hline
\end{tabular}




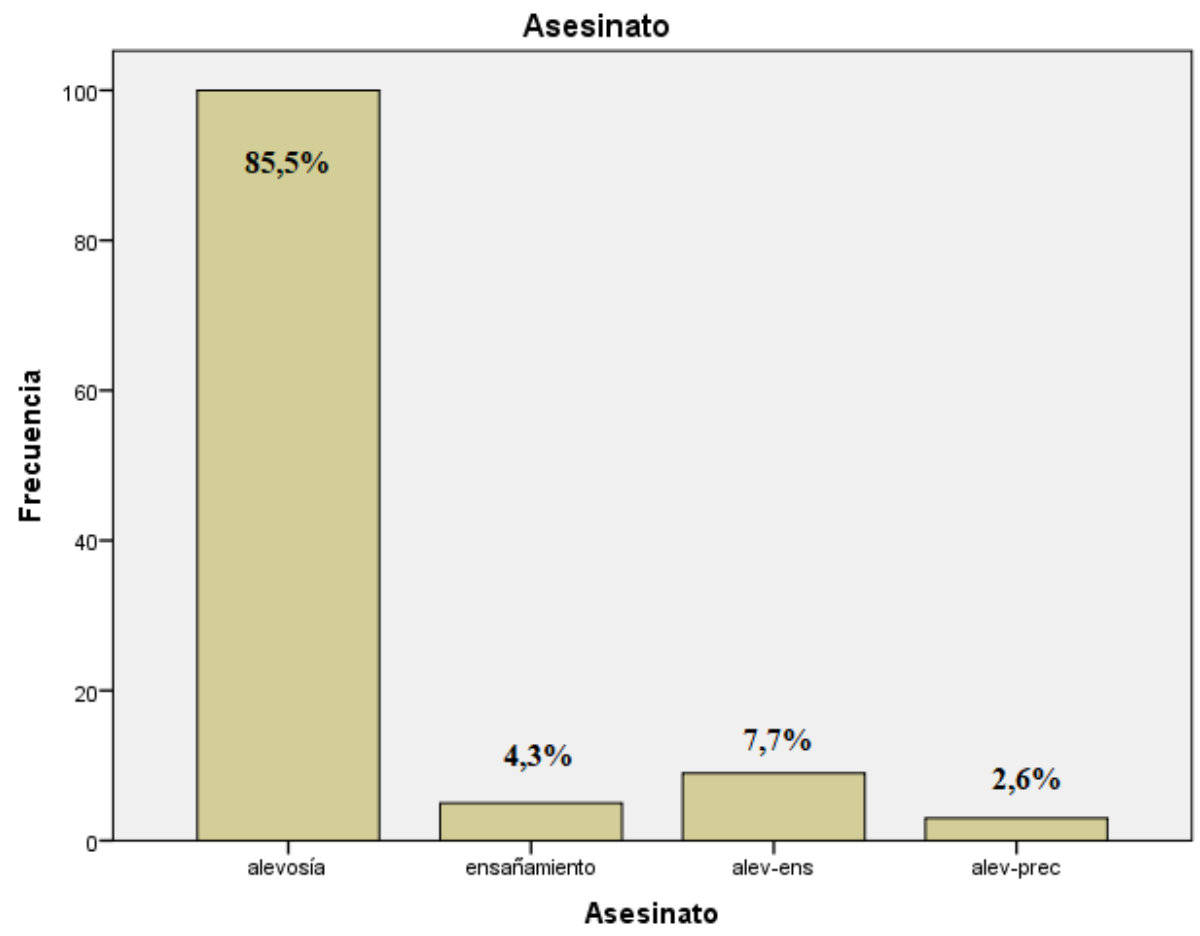

Gráfico 14: porcentajes del valor asesinato.

- $\mathrm{Al}$ darse esta circunstancia, es lógico que prácticamente casi todos los recursos sean en los asesinatos por alevosía (85’3\%), aunque llama la atención que por ensañamiento solo se recurre 1 de los 5 (el $20 \%$ frente al $80 \%$ no recurrido dentro del ensañamiento).

Resumen de procesamiento de casos

\begin{tabular}{|c|c|c|c|c|c|c|}
\hline & \multicolumn{6}{|c|}{ Casos } \\
\hline & \multicolumn{2}{|c|}{ Válidos } & \multicolumn{2}{|c|}{ Perdidos } & \multicolumn{2}{|c|}{ Total } \\
\hline & $\mathrm{N}$ & Porcentaje & $\mathrm{N}$ & Porcentaje & $\mathrm{N}$ & Porcentaje \\
\hline Asesinato $*$ Apelación TSJ & 117 & $100,0 \%$ & 0 & $0,0 \%$ & 117 & $100,0 \%$ \\
\hline
\end{tabular}


Tabla cruzada Asesinato*Apelación TSJ

\begin{tabular}{|c|c|c|c|c|c|}
\hline & & & \multicolumn{2}{|c|}{ Apelación TSJ } & \multirow[b]{2}{*}{ Total } \\
\hline & & & recurrido & no recurrido & \\
\hline \multirow[t]{16}{*}{ Asesinato } & alevosía & Recuento & 58 & 42 & 100 \\
\hline & & $\%$ dentro de Asesinato & $58,0 \%$ & $42,0 \%$ & $100,0 \%$ \\
\hline & & $\%$ dentro de Apelación TSJ & $85,3 \%$ & $85,7 \%$ & $85,5 \%$ \\
\hline & & $\%$ del total & $49,6 \%$ & $35,9 \%$ & $85,5 \%$ \\
\hline & ensañamiento & Recuento & 1 & 4 & 5 \\
\hline & & $\%$ dentro de Asesinato & $20,0 \%$ & $80,0 \%$ & $100,0 \%$ \\
\hline & & $\%$ dentro de Apelación TSJ & $1,5 \%$ & $8,3 \%$ & $4,3 \%$ \\
\hline & & $\%$ del total & $0,9 \%$ & $3,4 \%$ & $4,3 \%$ \\
\hline & alev-ens & Recuento & 6 & 3 & 9 \\
\hline & & $\%$ dentro de Asesinato & $66,7 \%$ & $33,3 \%$ & $100,0 \%$ \\
\hline & & $\%$ dentro de Apelación TSJ & $8,8 \%$ & $6,1 \%$ & $7,7 \%$ \\
\hline & & $\%$ del total & $5,1 \%$ & $2,6 \%$ & $7,7 \%$ \\
\hline & alev-prec & Recuento & 3 & 0 & 3 \\
\hline & & $\%$ dentro de Asesinato & $100,0 \%$ & $0,0 \%$ & $100,0 \%$ \\
\hline & & $\%$ dentro de Apelación TSJ & $4,4 \%$ & $0,0 \%$ & $2,6 \%$ \\
\hline & & $\%$ del total & $2,6 \%$ & $0,0 \%$ & $2,6 \%$ \\
\hline \multirow[t]{4}{*}{ Total } & & Recuento & 68 & 49 & 117 \\
\hline & & $\%$ dentro de Asesinato & $58,1 \%$ & $41,9 \%$ & $100,0 \%$ \\
\hline & & $\%$ dentro de Apelación TSJ & $100,0 \%$ & $100,0 \%$ & $100,0 \%$ \\
\hline & & $\%$ del total & $58,1 \%$ & $41,9 \%$ & $100,0 \%$ \\
\hline
\end{tabular}




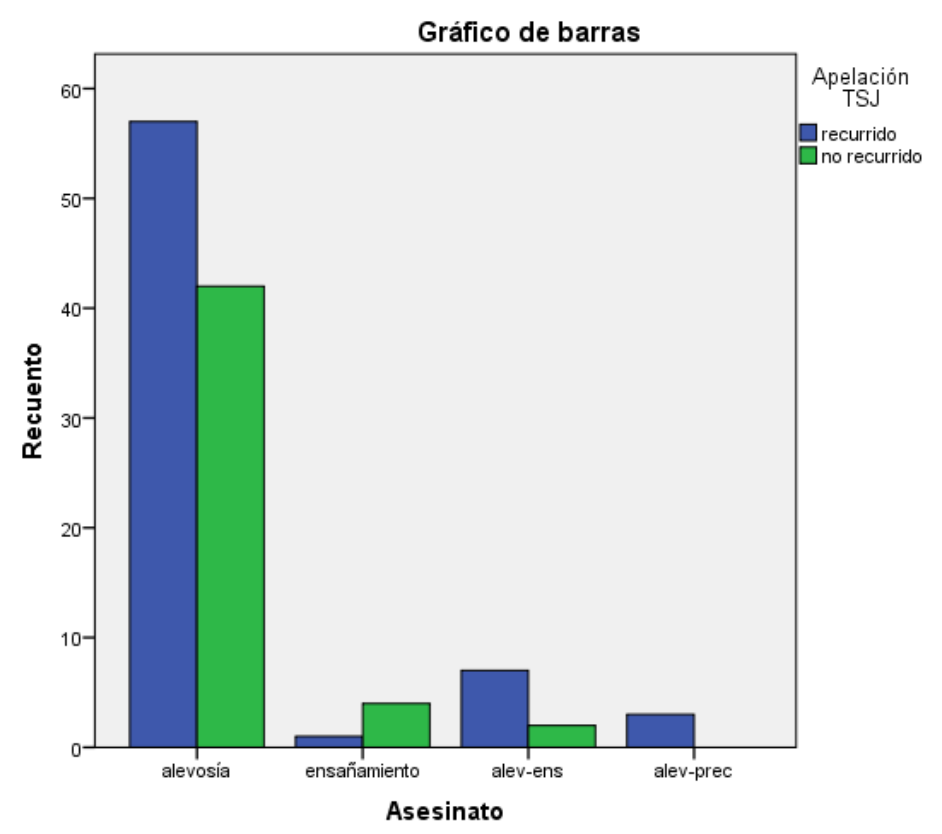

Gráfico 15: asesinatos recurridos en apelación al TSJ.

2. Para la variable veredicto.

De los 235: 168 son veredictos de culpabilidad (71'4\%), 29 de inculpabilidad $\left(12^{\prime} 4 \%\right)$, en 35 ocasiones se dictó sentencia de conformidad (15\%) -es decir, no hubo veredicto del jurado- y en 3 la sentencia fue absolutoria por otros motivos (1'3\%). Por tanto, se ha emitido veredicto en un $83^{\circ} 8 \%$ de los enjuiciamientos y una mayoría de ellos han sido de culpabilidad.

\section{Estadísticos}

Veredicto AP

\begin{tabular}{|c|c|c|}
\hline $\mathrm{N}$ & Válido & 235 \\
\hline & Perdidos & 0 \\
\hline
\end{tabular}




\section{Veredicto AP}

\begin{tabular}{|r|r|r|r|r|}
\hline & Frecuencia & Porcentaje & Porcentaje válido & $\begin{array}{r}\text { Porcentaje } \\
\text { acumulado }\end{array}$ \\
\hline Válido culpable & 168 & 71,5 & 71,5 & 71,5 \\
no culpable & 29 & 12,3 & 12,3 & 83,8 \\
s.conformidad & 35 & 14,9 & 14,9 & 98,7 \\
absolución & 3 & 1,3 & 1,3 & 100,0 \\
Total & 235 & 100,0 & 100,0 & \\
\hline
\end{tabular}

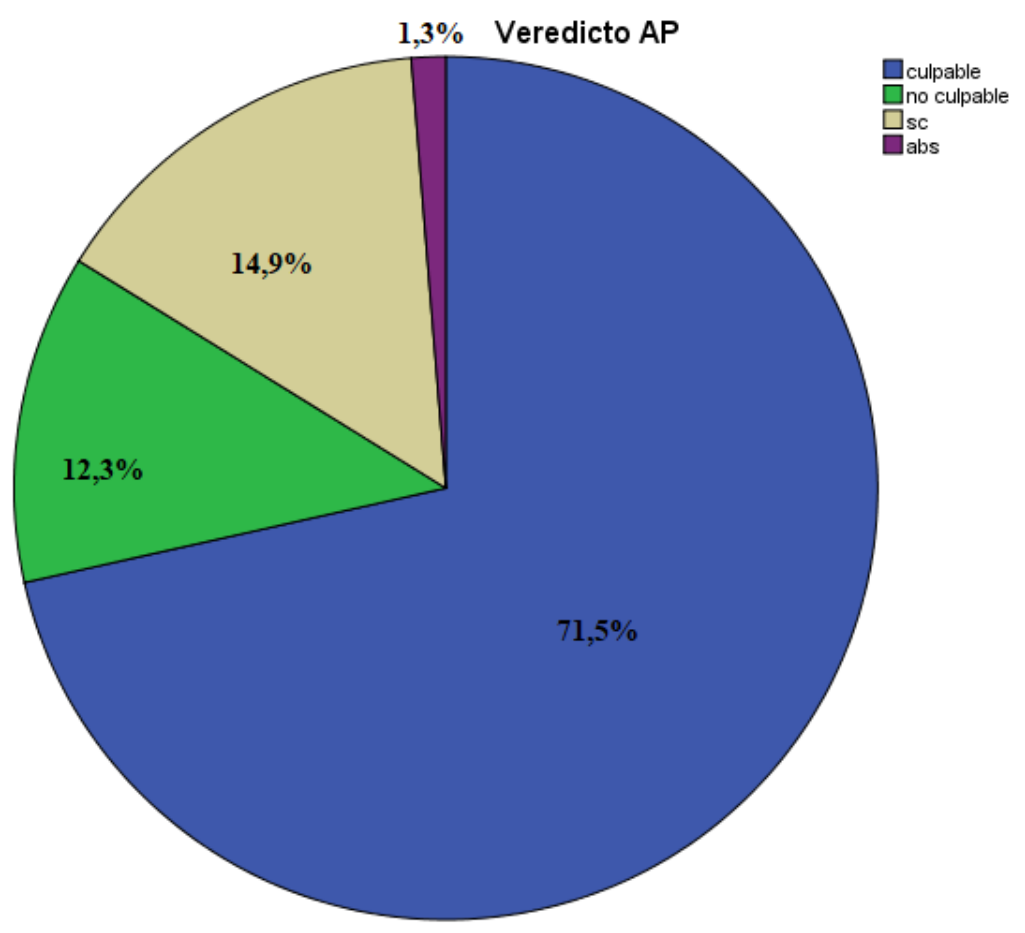

Gráfico 16: porcentajes para la variable veredicto. 


\section{Para la variable sexo.}

Del total de 235 veredictos, 199 hombres (84'7\%) fueron juzgados, frente a 36 mujeres (15,3\%). Observamos una clara diferencia en el número de hombres que cometen este tipo de delitos, bastante mayor al de las mujeres homicidas.

Estadísticos

Sexo

\begin{tabular}{|c|c|c|}
\hline $\mathrm{N}$ & Válido & 235 \\
\hline & Perdidos & 0 \\
\hline
\end{tabular}

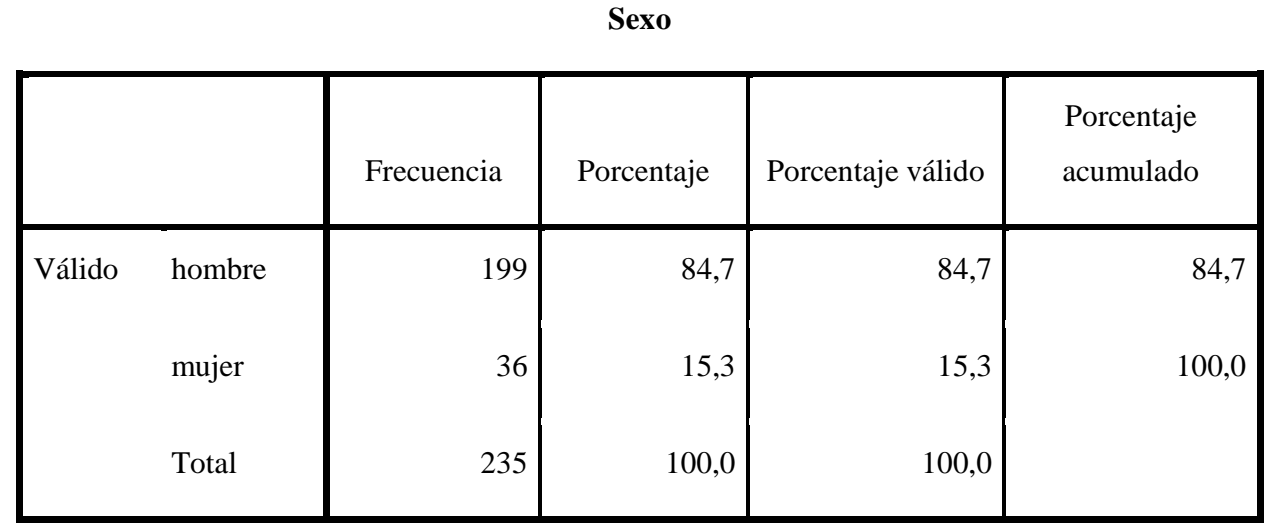

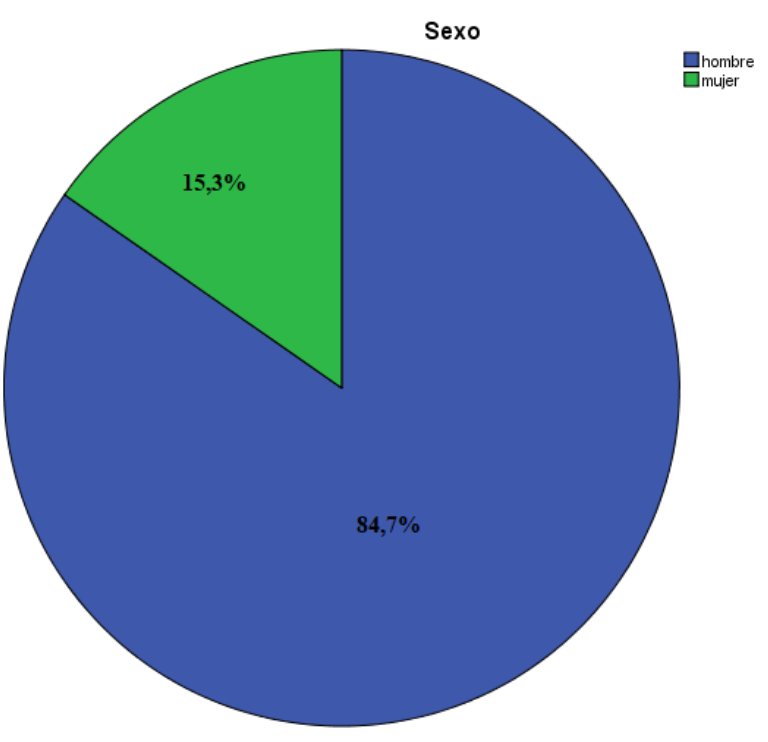

Gráfico 17: porcentajes para la variable sexo. 


\section{Para la variable recurso.}

De los 235 veredictos, 127 (54,0\%) han sido recurridos en apelación ante el TSJCyL y 108 (46,0\%) no se recurrieron. Un poco más de la mitad de las sentencias disponibles fueron recurridas, aunque si tenemos en cuenta el dato de que de los 108 veredictos no recurridos, en 35 se dictó sentencia de conformidad, nos queda que en solo 73 de los 235 veredictos emitidos en los que cabía recurso, este no se efectuó.

Estadísticos

Recurso TSJ

\begin{tabular}{|ll|r|}
\hline $\mathrm{N}$ & Válido & 235 \\
& Perdidos & 0 \\
\hline
\end{tabular}

Recurso TSJ

\begin{tabular}{|r|r|r|r|r|}
\hline & Frecuencia & Porcentaje & Porcentaje válido & $\begin{array}{r}\text { Porcentaje } \\
\text { acumulado }\end{array}$ \\
\hline Válido recurrida & 127 & 54,0 & 54,0 & 54,0 \\
& 108 & 46,0 & 46,0 & 100,0 \\
no recurrida & 235 & 100,0 & 100,0 & \\
\hline
\end{tabular}




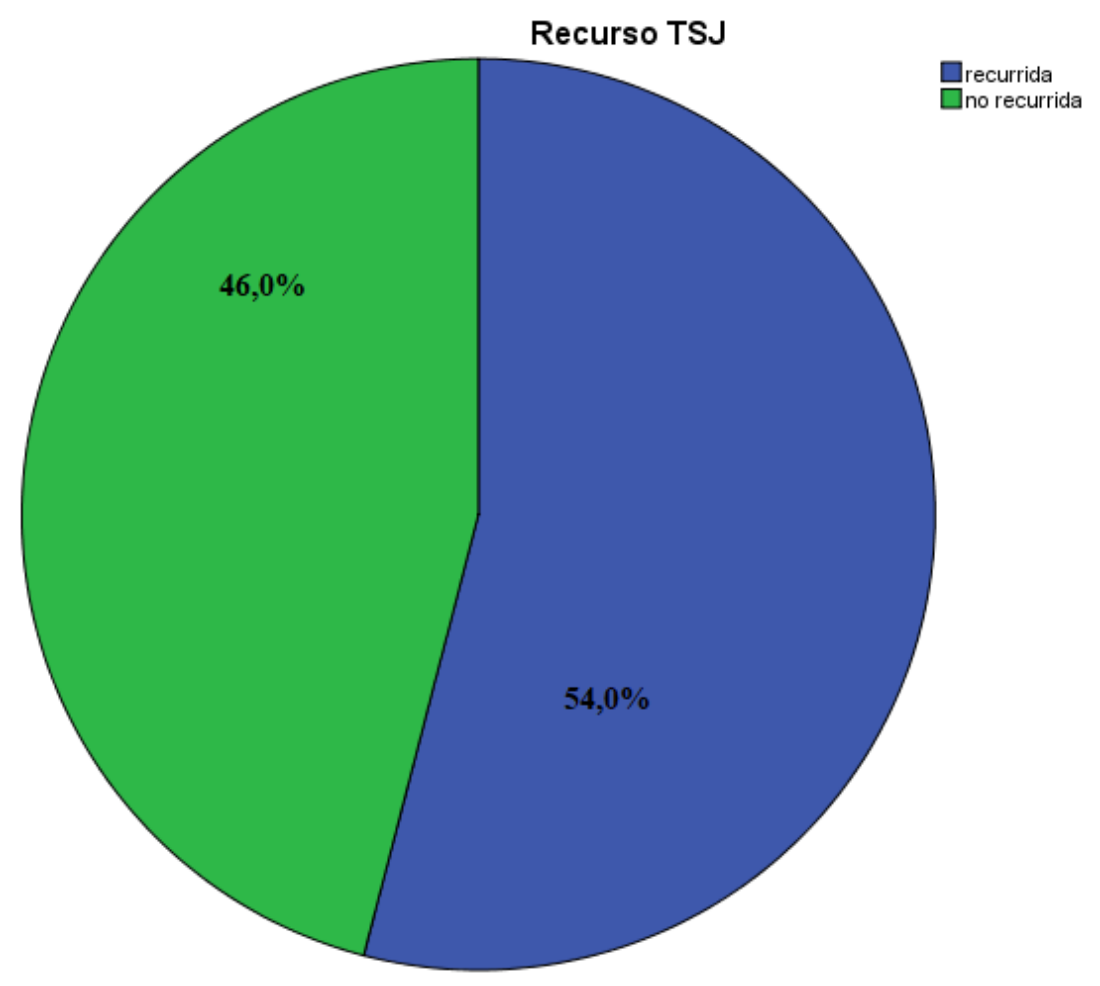

Gráfico 18: porcentajes para la variable recurso.

\subsubsection{Variables cruzadas.}

Una vez examinadas las variables por separado, procedemos a cruzarlas para analizar la relación entre ellas y los respectivos porcentajes con detalle. Hemos obtenido los siguientes resultados:

\section{Correlación entre la variable delito y la variable veredicto.}

Con esta combinación pretendemos estudiar si existe alguna diferencia entre los distintos delitos contra la vida, a la hora de emitir el veredicto por parte del jurado, si declaran más culpables a los acusados por asesinato, por homicidio o si no hay distinción relevante entre ambos.

Al cruzar las variables, en las tablas podemos apreciar varios aspectos. Tomamos como ejemplo esta primera relación. 
- En primer lugar, la descripción del número de homicidios y de asesinatos y, en cada uno de ellos, cuántos se corresponden con veredicto de culpabilidad, inculpabilidad, conformidad o absolución por otros motivos. Esto se indica en la tabla "Recuento".

- En segundo lugar, la "Tabla cruzada" nos muestra cada uno de esos conceptos con sus respectivos porcentajes, es decir, que nos permite conocer:

○ por una parte $y$, dentro de la variable delito, qué porcentaje de homicidios son de culpabilidad, inculpabilidad, etc., y lo mismo con el asesinato; y

o por otra parte, saber los porcentajes respecto a la variable veredicto, es decir, del número de culpabilidades cuántas se han producido en casos de homicidio y cuántas en asesinatos, y de igual forma en los demás veredictos, así como el total en todos los casos.

Este ejemplo es aplicable a todas las variables cruzadas que vamos a analizar.

Resumen de procesamiento de casos

\begin{tabular}{|c|c|c|c|c|c|c|}
\hline & \multicolumn{6}{|c|}{ Casos } \\
\hline & \multicolumn{2}{|c|}{ Válidos } & \multicolumn{2}{|c|}{ Perdidos } & \multicolumn{2}{|c|}{ Total } \\
\hline & $\mathrm{N}$ & Porcentaje & $\mathrm{N}$ & Porcentaje & $\mathrm{N}$ & Porcentaje \\
\hline Delito * Veredicto AP & 235 & $100,0 \%$ & 0 & $0,0 \%$ & 235 & $100,0 \%$ \\
\hline
\end{tabular}




\begin{tabular}{|rc|r|r|r|r|r|}
\hline & \multicolumn{5}{|c|}{ Veredicto AP } & \\
\cline { 2 - 6 } & Culpable & no culpable & sc & Abs & Total \\
\hline Delito & Homicidio & 76 & 19 & 22 & 1 & 118 \\
& Asesinato & 92 & 10 & 13 & 2 & 117 \\
Total & 168 & 29 & & 35 & 3 & 235 \\
\hline
\end{tabular}

- Observamos que en los 118 casos de homicidio, se emitieron 76 veredictos de culpabilidad (64\% $4 \%$ ), 19 de no culpable (16'1\%), 22 sentencias de conformidad (18'6\%) y 1 absolución sin veredicto del jurado (0’8\%). Claramente hay mayoría de veredictos de culpabilidad, ya que incluso el porcentaje de sentencias de conformidad, supera el de veredictos de inculpabilidad.

- Respecto a los asesinatos, de los 117 , en 92 se dicta veredicto de culpabilidad (78'6\%), en 10 de inculpabilidad (8'5\%), 13 sentencias de conformidad (11'1\%) y 2 sentencias absolutorias sin veredicto del jurado (1'7\%). También en este caso las sentencias de conformidad superan los veredictos de no culpable aunque existe menor número de conformidades que en los homicidios y mayor número de condenas tras el veredicto. 
Tabla cruzada Delito* Veredicto AP

\begin{tabular}{|c|c|c|c|c|c|c|}
\hline & & & \multicolumn{4}{|c|}{ Veredicto AP } \\
\hline & & & Culpable & no culpable & $\mathrm{sc}$ & Abs \\
\hline \multirow[t]{8}{*}{ Delito } & homicidio & Recuento & 76 & 19 & 22 & 1 \\
\hline & & $\%$ dentro de Delito & $64,4 \%$ & $16,1 \%$ & $18,6 \%$ & $0,8 \%$ \\
\hline & & $\%$ dentro de Veredicto AP & $45,2 \%$ & $65,5 \%$ & $62,9 \%$ & $33,3 \%$ \\
\hline & & $\%$ del total & $32,3 \%$ & $8,1 \%$ & $9,4 \%$ & $0,4 \%$ \\
\hline & asesinato & Recuento & 92 & 10 & 13 & 2 \\
\hline & & $\%$ dentro de Delito & $78,6 \%$ & $8,5 \%$ & $11,2 \%$ & $1,7 \%$ \\
\hline & & $\%$ dentro de Veredicto AP & $54,8 \%$ & $34,5 \%$ & $37,1 \%$ & $66,7 \%$ \\
\hline & & $\%$ del total & $39,1 \%$ & $4,3 \%$ & $5,6 \%$ & $0,9 \%$ \\
\hline \multirow{4}{*}{\multicolumn{2}{|c|}{ Total }} & Recuento & 168 & 29 & 35 & 3 \\
\hline & & $\%$ dentro de Delito & $71,5 \%$ & $12,4 \%$ & $15,0 \%$ & $1,3 \%$ \\
\hline & & $\%$ dentro de Veredicto AP & $100,0 \%$ & $100,0 \%$ & $100,0 \%$ & $100,0 \%$ \\
\hline & & $\%$ del total & $71,5 \%$ & $12,4 \%$ & $15,0 \%$ & $1,3 \%$ \\
\hline
\end{tabular}


Tabla cruzada Delito*Veredicto AP

\begin{tabular}{|c|c|c|c|}
\hline & & & Total \\
\hline \multirow[t]{8}{*}{ Delito } & homicidio & Recuento & 118 \\
\hline & & $\%$ dentro de Delito & $100,0 \%$ \\
\hline & & $\%$ dentro de Veredicto AP & $50,2 \%$ \\
\hline & & $\%$ del total & $50,2 \%$ \\
\hline & Asesinato & Recuento & 117 \\
\hline & & $\%$ dentro de Delito & $100,0 \%$ \\
\hline & & $\%$ dentro de Veredicto AP & $49,8 \%$ \\
\hline & & $\%$ del total & $49,8 \%$ \\
\hline \multirow[t]{4}{*}{ Total } & & Recuento & 235 \\
\hline & & $\%$ dentro de Delito & $100,0 \%$ \\
\hline & & $\%$ dentro de Veredicto AP & $100,0 \%$ \\
\hline & & $\%$ del total & $100,0 \%$ \\
\hline
\end{tabular}

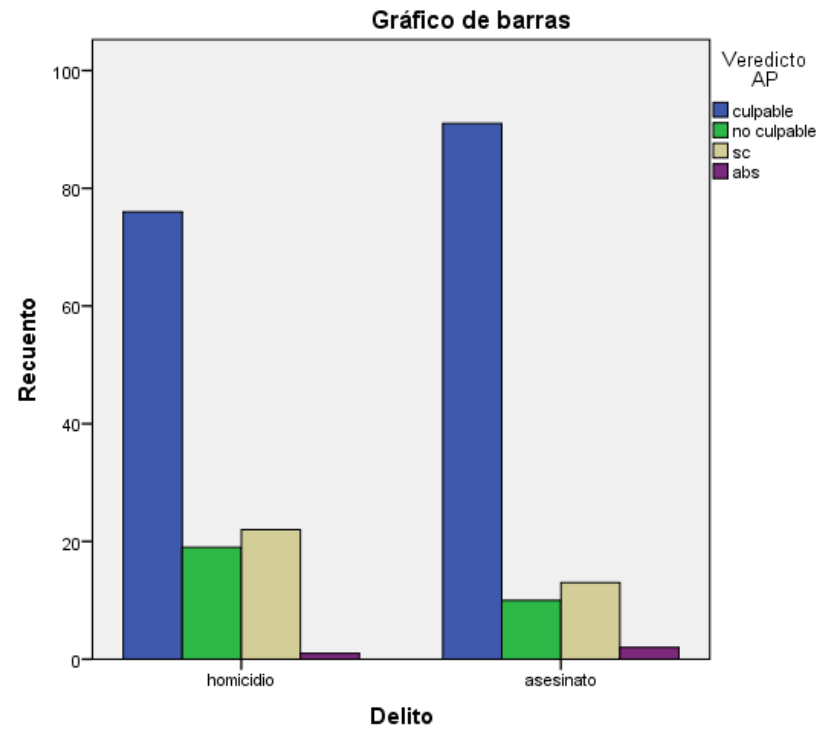

Gráfico 19: porcentajes para las variables cruzadas delito y veredicto. 
2. Correlación entre las variables delito y sexo.

Con este análisis podemos ver qué tipo delictivo cometen más los hombres y cuál las mujeres o si el número es igual.

Resumen de procesamiento de casos

\begin{tabular}{|c|c|c|c|c|c|c|}
\hline & \multicolumn{6}{|c|}{ Casos } \\
\hline & \multicolumn{2}{|c|}{ Válidos } & \multicolumn{2}{|c|}{ Perdidos } & \multicolumn{2}{|c|}{ Total } \\
\hline & $\mathrm{N}$ & Porcentaje & $\mathrm{N}$ & Porcentaje & $\mathrm{N}$ & Porcentaje \\
\hline Delito * Sexo & 235 & $100,0 \%$ & 0 & $0,0 \%$ & 235 & $100,0 \%$ \\
\hline
\end{tabular}

Tabla cruzada Delito*Sexo

Recuento

\begin{tabular}{|lc|r|r|r|}
\hline & \multicolumn{2}{|c|}{ Sexo } & \multirow{2}{*}{ Total } \\
\cline { 3 - 4 } & \multicolumn{2}{|c|}{ hombre } & mujer & \multirow{2}{*}{ Tom } \\
\hline Delito & homicidio & 104 & 14 & 118 \\
& asesinato & 95 & 22 & 117 \\
Total & & 199 & 36 & 235 \\
\hline
\end{tabular}

- Como se ha visto, los hombres cometen estos delitos contra la vida en general, en bastantes más casos que las mujeres. Sin embargo, sí se produce una diferencia dentro de cada grupo, ya que ellos cometen más homicidios (104, el $52^{\prime} 3 \%$ ) que asesinatos $\left(95\right.$, el $\left.47^{\prime} 7 \%\right)$ y, por el contrario, ellas más asesinatos (22, el 61'1\%) que homicidios (14, el $\left.38^{\prime} 9 \%\right)$. Esto puede deberse a que los hombres normalmente emplean más la fuerza física, mientras que 
ellas lo hacen de otra forma y suelen actuar con alevosía, uno de los elementos que caracterizan el asesinato.

- Según se ha explicado anteriormente, los hombres han sido acusados en 104 de los 118 homicidios (88\%1\%) y las mujeres en tan solo 14 (11'9\%), mientras que los asesinatos han sido cometidos por 95 hombres (81'2\%) y 22 mujeres $\left(18^{\prime} 8 \%\right)$.

Tabla cruzada Delito*Sexo

\begin{tabular}{|c|c|c|c|c|c|}
\hline & & & \multicolumn{2}{|c|}{ Sexo } & \multirow[b]{2}{*}{ Total } \\
\hline & & & Hombre & Mujer & \\
\hline \multirow[t]{8}{*}{ Delito } & homicidio & Recuento & 105 & 13 & 118 \\
\hline & & $\%$ dentro de Delito & $88,1 \%$ & $11,9 \%$ & $100,0 \%$ \\
\hline & & $\%$ dentro de Sexo & $52,3 \%$ & $38,9 \%$ & $50,2 \%$ \\
\hline & & $\%$ del total & $44,3 \%$ & $6,0 \%$ & $50,2 \%$ \\
\hline & Asesinato & Recuento & 95 & 22 & 117 \\
\hline & & $\%$ dentro de Delito & $81,2 \%$ & $18,8 \%$ & $100,0 \%$ \\
\hline & & $\%$ dentro de Sexo & $47,7 \%$ & $61,1 \%$ & $49,8 \%$ \\
\hline & & $\%$ del total & $40,4 \%$ & $9,4 \%$ & $49,8 \%$ \\
\hline \multirow[t]{4}{*}{ Total } & & Recuento & 199 & 36 & 235 \\
\hline & & $\%$ dentro de Delito & $84,7 \%$ & $15,3 \%$ & $100,0 \%$ \\
\hline & & $\%$ dentro de Sexo & $100,0 \%$ & $100,0 \%$ & $100,0 \%$ \\
\hline & & $\%$ del total & $84,7 \%$ & $15,3 \%$ & $100,0 \%$ \\
\hline
\end{tabular}




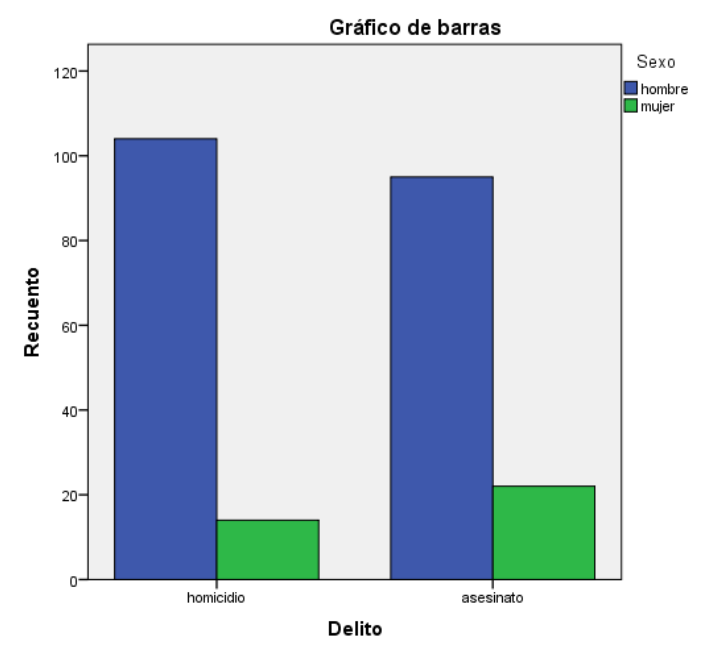

Gráfico 20: porcentajes para las variables cruzadas delito y sexo.

\section{Correlación entre las variables delito y recurso.}

Con la siguiente relación, se conecta cuántos delitos de cada clase se recurren en apelación y cuántos no para compararlos entre sí.

Resumen de procesamiento de casos

\begin{tabular}{|c|c|c|c|c|c|c|}
\hline & \multicolumn{6}{|c|}{ Casos } \\
\hline & \multicolumn{2}{|c|}{ Válidos } & \multicolumn{2}{|c|}{ Perdidos } & \multicolumn{2}{|c|}{ Total } \\
\hline & $\mathrm{N}$ & Porcentaje & $\mathrm{N}$ & Porcentaje & $\mathrm{N}$ & Porcentaje \\
\hline Delito * Recurso TSJ & 235 & $100,0 \%$ & 0 & $0,0 \%$ & 235 & $100,0 \%$ \\
\hline
\end{tabular}

Tabla cruzada Delito* Recurso TSJ

Recuento

\begin{tabular}{|lc|r|r|r|}
\hline & \multicolumn{2}{|c|}{ Recurso TSJ } & \multirow{2}{*}{ Total } \\
\cline { 2 - 4 } & recurrida & no recurrida & \multirow{2}{*}{ Ton } \\
\hline Delito & homicidio & 60 & 58 & 118 \\
& asesinato & 67 & 50 & 117 \\
Total & & 127 & 108 & 235 \\
\hline
\end{tabular}


Por delitos, contra los casos de asesinato se interponen más recursos que contra los de homicidio. Así, se recurrieron al TSJ 60 de los 118 veredictos de homicidio (50’8\%) y 67 de los 117 condenados por asesinato $\left(57^{\prime} 3 \%\right)$. El porcentaje es parecido, aunque superior en los asesinatos.

Tabla cruzada Delito* Recurso TSJ

\begin{tabular}{|c|c|c|c|c|c|}
\hline & & & \multicolumn{2}{|c|}{ Recurso TSJ } & \multirow[b]{2}{*}{ Total } \\
\hline & & & recurrida & no recurrida & \\
\hline \multirow[t]{8}{*}{ Delito } & homicidio & Recuento & 60 & 58 & 118 \\
\hline & & $\%$ dentro de Delito & $50,8 \%$ & $49,2 \%$ & $100,0 \%$ \\
\hline & & $\%$ dentro de Recurso TSJ & $47,2 \%$ & $53,7 \%$ & $50,2 \%$ \\
\hline & & $\%$ del total & $25,5 \%$ & $24,7 \%$ & $50,2 \%$ \\
\hline & asesinato & Recuento & 67 & 50 & 117 \\
\hline & & $\%$ dentro de Delito & $57,3 \%$ & $42,7 \%$ & $100,0 \%$ \\
\hline & & $\%$ dentro de Recurso TSJ & $52,8 \%$ & $46,3 \%$ & $49,8 \%$ \\
\hline & & $\%$ del total & $28,5 \%$ & $21,3 \%$ & $49,8 \%$ \\
\hline \multirow{4}{*}{\multicolumn{2}{|c|}{ Total }} & Recuento & 127 & 108 & 235 \\
\hline & & $\%$ dentro de Delito & $54,0 \%$ & $46,0 \%$ & $100,0 \%$ \\
\hline & & $\%$ dentro de Recurso TSJ & $100,0 \%$ & $100,0 \%$ & $100,0 \%$ \\
\hline & & $\%$ del total & $54,0 \%$ & $46,0 \%$ & $100,0 \%$ \\
\hline
\end{tabular}




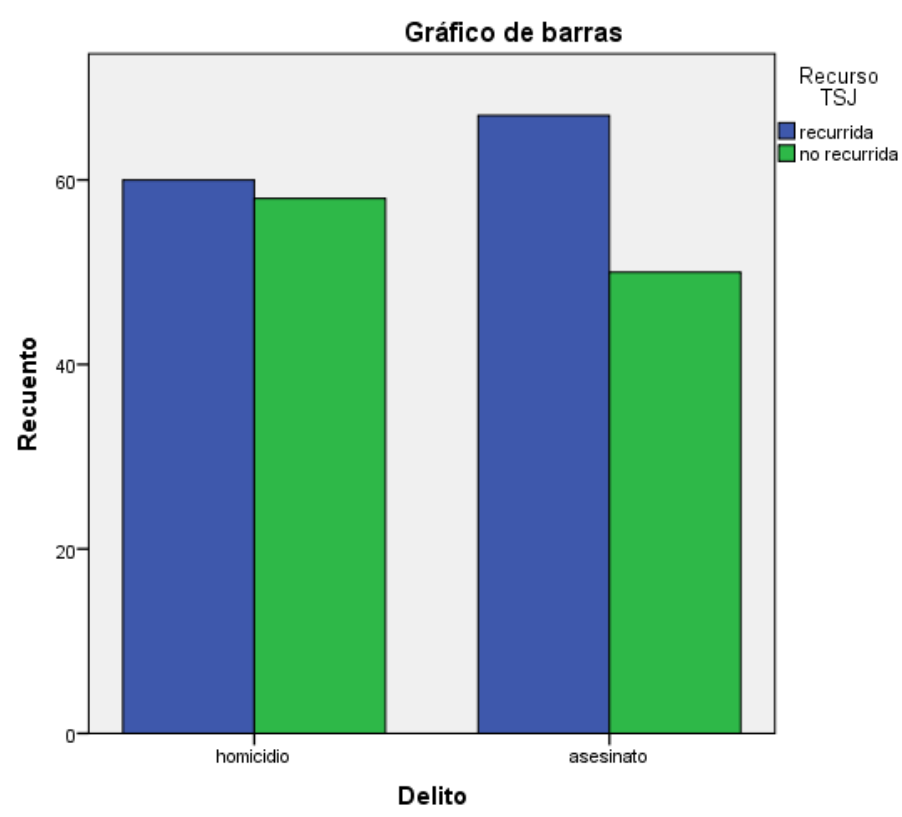

Gráfico 21: porcentajes para las variables cruzadas delito y recurso.

\section{Correlación entre las variables veredicto y sexo.}

Consideramos esta conexión con el fin de comprobar si se dan más veredictos de culpabilidad en uno u otro. Si por ejemplo el jurado es más benévolo con las mujeres o viceversa, o si esta circunstancia es irrelevante y no tiene ninguna repercusión en los veredictos.

Resumen de procesamiento de casos

\begin{tabular}{|c|c|c|c|c|c|c|}
\hline & \multicolumn{6}{|c|}{ Casos } \\
\hline & \multicolumn{2}{|c|}{ Válidos } & \multicolumn{2}{|c|}{ Perdidos } & \multicolumn{2}{|c|}{ Total } \\
\hline & $\mathrm{N}$ & Porcentaje & $\mathrm{N}$ & Porcentaje & $\mathrm{N}$ & Porcentaje \\
\hline Veredicto AP $*$ Sexo & 235 & $100,0 \%$ & 0 & $0,0 \%$ & 235 & $100,0 \%$ \\
\hline
\end{tabular}




\begin{tabular}{|c|c|c|c|c|}
\hline & & \multicolumn{2}{|c|}{ Sexo } & \multirow[b]{2}{*}{ Total } \\
\hline & & hombre & mujer & \\
\hline \multirow[t]{4}{*}{ Veredicto AP } & culpable & 144 & 24 & 168 \\
\hline & no culpable & 27 & 2 & 29 \\
\hline & $\mathrm{sc}$ & 25 & 10 & 35 \\
\hline & abs & 3 & 0 & 3 \\
\hline Total & & 199 & 36 & 235 \\
\hline
\end{tabular}

$\mathrm{Al}$ cruzar estas dos variables, comprobamos que los jurados no hacen distinción por sexos y no tienden a declarar culpable o no culpable más a uno que a otro.

- Los hombres han sido declarados culpables en 144 veredictos de los 199 (72’4\%) y las mujeres en 24 de los 36 (66’7\%).

- Respecto a los veredictos de inculpabilidad, sí existe más diferencia, con 27 hombres (el 13'6\%) frente a 2 mujeres (el 5'6\%).

- Esto también se ve influido por el porcentaje de sentencias de conformidad, que es donde más distancia se aprecia. En caso de las mujeres es más alto, $27^{\prime} 8 \%$, por el $12^{\prime} 6 \%$ de conformidades en los hombres, además de un 1'5\% restante en el que los hombres han sido absueltos en 3 ocasiones por otros motivos, algo que no se ha dado en el caso de ninguna mujer. 
Tabla cruzada Veredicto AP*Sexo

\begin{tabular}{|c|c|c|c|c|c|}
\hline & & & \multicolumn{2}{|c|}{ Sexo } & \multirow[b]{2}{*}{ Total } \\
\hline & & & hombre & mujer & \\
\hline \multirow[t]{16}{*}{ Veredicto AP } & culpable & Recuento & 144 & 24 & 168 \\
\hline & & $\%$ dentro de Veredicto AP & $85,7 \%$ & $14,3 \%$ & $100,0 \%$ \\
\hline & & $\%$ dentro de Sexo & $72,4 \%$ & $66,7 \%$ & $71,5 \%$ \\
\hline & & $\%$ del total & $61,3 \%$ & $10,2 \%$ & $71,5 \%$ \\
\hline & no culpable & Recuento & 27 & 2 & 29 \\
\hline & & $\%$ dentro de Veredicto AP & $93,1 \%$ & $6,9 \%$ & $100,0 \%$ \\
\hline & & $\%$ dentro de Sexo & $13,6 \%$ & $5,6 \%$ & $12,3 \%$ \\
\hline & & $\%$ del total & $11,5 \%$ & $0,9 \%$ & $12,3 \%$ \\
\hline & $\mathrm{sc}$ & Recuento & 25 & 10 & 35 \\
\hline & & $\%$ dentro de Veredicto AP & $71,4 \%$ & $28,6 \%$ & $100,0 \%$ \\
\hline & & $\%$ dentro de Sexo & $12,6 \%$ & $28,6 \%$ & $15,0 \%$ \\
\hline & & $\%$ del total & $10,7 \%$ & $4,3 \%$ & $15,0 \%$ \\
\hline & abs & Recuento & 3 & 0 & 3 \\
\hline & & $\%$ dentro de Veredicto AP & $100,0 \%$ & $0,0 \%$ & $100,0 \%$ \\
\hline & & $\%$ dentro de Sexo & $1,5 \%$ & $0,0 \%$ & $1,3 \%$ \\
\hline & & $\%$ del total & $1,3 \%$ & $0,0 \%$ & $1,3 \%$ \\
\hline \multirow[t]{4}{*}{ Total } & & Recuento & 199 & 36 & 235 \\
\hline & & $\%$ dentro de Veredicto AP & $84,7 \%$ & $15,3 \%$ & $100,0 \%$ \\
\hline & & $\%$ dentro de Sexo & $100,0 \%$ & $100,0 \%$ & $100,0 \%$ \\
\hline & & $\%$ del total & $84,7 \%$ & $15,3 \%$ & $100,0 \%$ \\
\hline
\end{tabular}




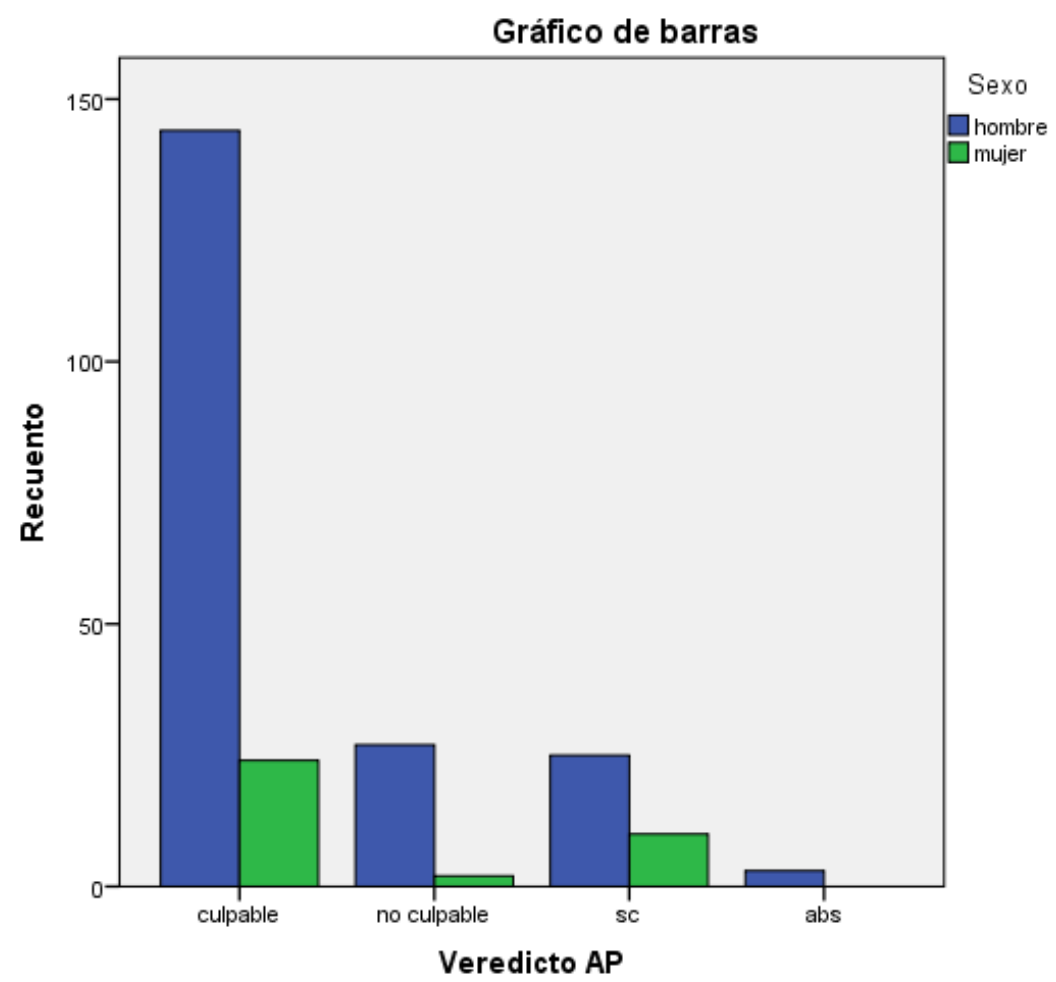

Gráfico 22: porcentajes para las variables cruzadas veredicto y sexo.

\section{Correlación entre las variables sexo y recurso.}

Igualmente, procedemos a examinar si existen o no diferencias en el sexo del condenado/absuelto a la hora de recurrir.

Resumen de procesamiento de casos

\begin{tabular}{|c|c|c|c|c|c|c|}
\hline & \multicolumn{6}{|c|}{ Casos } \\
\hline & \multicolumn{2}{|c|}{ Válidos } & \multicolumn{2}{|c|}{ Perdidos } & \multicolumn{2}{|c|}{ Total } \\
\hline & $\mathrm{N}$ & Porcentaje & $\mathrm{N}$ & Porcentaje & $\mathrm{N}$ & Porcentaje \\
\hline Sexo * Recurso TSJ & 235 & $100,0 \%$ & 0 & $0,0 \%$ & 235 & $100,0 \%$ \\
\hline
\end{tabular}




\begin{tabular}{|rc|r|r|r|}
\hline & \multicolumn{2}{|c|}{ Recurso TSJ } & \multirow{2}{*}{ Total } \\
\cline { 3 - 4 } & & recurrida & no recurrida & \multirow{2}{*}{ Ton } \\
\cline { 3 - 4 } & Mujer & 111 & 88 & 199 \\
& & 16 & 20 & 36 \\
Total & & 127 & 108 & 235 \\
\hline
\end{tabular}

Tampoco se observa una diferencia significativa entre las resoluciones recurridas y el sexo del recurrente, con una ligera mayoría respecto a los hombres.

- Dentro de la variable sexo, vemos que, entre los hombres, ha recurrido el $55^{\prime} 8 \%$ de ellos (111 veredictos) y, entre las mujeres, el 44 ' $2 \%$ de ellas (16 veredictos).

- En cuanto a los recursos en general, al analizar la variable recurso, comprobamos que ellos lo han efectuado en bastantes más ocasiones, correspondiéndose con la proporción entre acusados hombres y acusadas mujeres (el $87^{\prime} 4 \%$ de los recursos los interponen ellos frente al $12^{\prime} 6 \%$ interpuestos por ellas). 
Tabla cruzada Sexo*Recurso TSJ

\begin{tabular}{|c|c|c|c|c|c|}
\hline & & & \multicolumn{2}{|c|}{ Recurso TSJ } & \multirow[b]{2}{*}{ Total } \\
\hline & & & recurrida & no recurrida & \\
\hline \multirow[t]{8}{*}{ Sexo } & Hombre & Recuento & 111 & 88 & 199 \\
\hline & & $\%$ dentro de Sexo & $55,8 \%$ & $44,2 \%$ & $100,0 \%$ \\
\hline & & $\%$ dentro de Recurso TSJ & $87,4 \%$ & $81,5 \%$ & $84,7 \%$ \\
\hline & & $\%$ del total & $47,2 \%$ & $37,4 \%$ & $84,7 \%$ \\
\hline & Mujer & Recuento & 16 & 20 & 36 \\
\hline & & $\%$ dentro de Sexo & $44,4 \%$ & $55,6 \%$ & $100,0 \%$ \\
\hline & & $\%$ dentro de Recurso TSJ & $12,6 \%$ & $18,5 \%$ & $15,3 \%$ \\
\hline & & $\%$ del total & $6,8 \%$ & $8,5 \%$ & $15,3 \%$ \\
\hline \multirow[t]{4}{*}{ Total } & & Recuento & 127 & 108 & 235 \\
\hline & & $\%$ dentro de Sexo & $54,0 \%$ & $46,0 \%$ & $100,0 \%$ \\
\hline & & $\%$ dentro de Recurso TSJ & $100,0 \%$ & $100,0 \%$ & $100,0 \%$ \\
\hline & & $\%$ del total & $54,0 \%$ & $46,0 \%$ & $100,0 \%$ \\
\hline
\end{tabular}

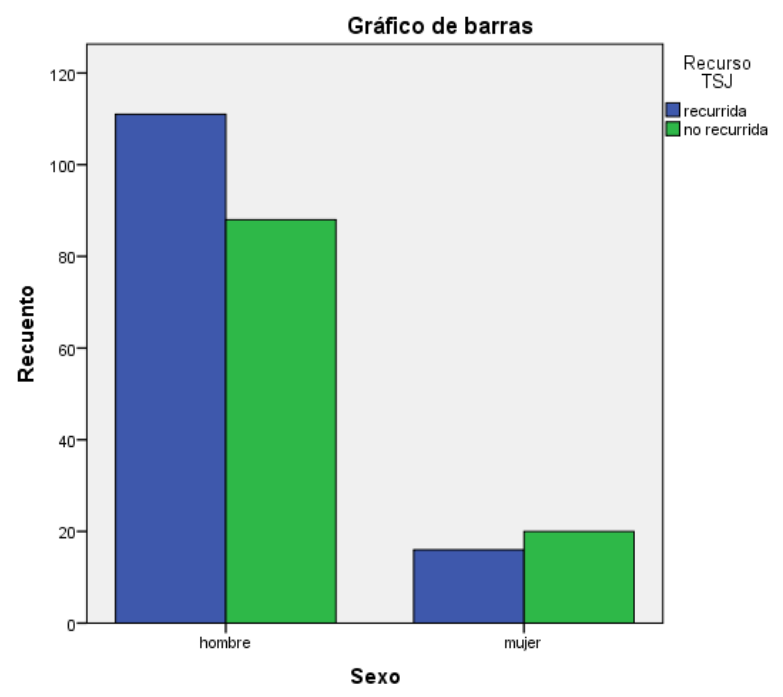

Gráfico 23: porcentajes para las variables cruzadas sexo y recurso. 
6.1.2. Resultados respecto a los recursos de apelación ante el Tribunal Superior de Justicia de Castilla y León.

De las 99 sentencias que nos constan como recurridas, se han obtenido 125 veredictos recurridos en apelación. Se asignan igualmente variables y valores en cada aspecto estudiado. Las variables que en esta ocasión hemos considerado son las siguientes:

- Veredicto de la Audiencia Provincial, con las modalidades:

- Valor 1: culpable.

- Valor 2: no culpable.

- Valor 3: absolución por otro motivo.

- Fallo del Tribunal Superior de Justicia, en recurso de apelación, con las modalidades:

- Valor 1: confirma el fallo de la AP y por lo tanto el veredicto del jurado.

- Valor 2: no confirma el fallo de la AP.

- Tipo de delito: con las modalidades:

- Valor 1: homicidio, a su vez, clasificado en doloso e imprudente.

- Valor 2: asesinato, a su vez, clasificado en función de las cuatro características que califican dicho tipo agravado.

- Sexo de la persona enjuiciada, con las modalidades:

- Valor 1: hombre.

- Valor 2: mujer.

- Provincia a la que corresponde el ámbito de la Audiencia, con las modalidades:

- Valor 1: Ávila.

- Valor 2: Burgos.

- Valor 3: León. 
- Valor 4: Palencia.

- Valor 5: Salamanca.

- Valor 6: Segovia.

- Valor 7: Soria.

- Valor 8: Valladolid.

- Valor 9: Zamora.

- Si se recurre en casación al Tribunal Supremo, con las modalidades:

- Valor 1: recurrido.

- Valor 2: no recurrido.

1. Resultados de los recursos de apelación relacionados con el veredicto.

En primer lugar, examinamos los resultados que arroja el estudio de los veredictos de culpabilidad y de inculpabilidad para ver cuántos confirma y cuántos no, el TSJ al ser recurridas las sentencias en apelación.

Estadísticos

\begin{tabular}{|c|c|c|c|}
\hline & & fallo TSJ & recurso TS \\
\hline $\mathrm{N}$ & Válido & 125 & 125 \\
\hline & Perdidos & 0 & 0 \\
\hline
\end{tabular}


fallo TSJ

\begin{tabular}{|r|r|r|r|r|}
\hline & Frecuencia & Porcentaje & Porcentaje válido & $\begin{array}{r}\text { Porcentaje } \\
\text { acumulado }\end{array}$ \\
\hline Válido confirma & 120 & 96,0 & 96,0 & 96,0 \\
& 5 & 4,0 & 4,0 & 100,0 \\
no confirma & 125 & 100,0 & 100,0 & \\
\hline
\end{tabular}

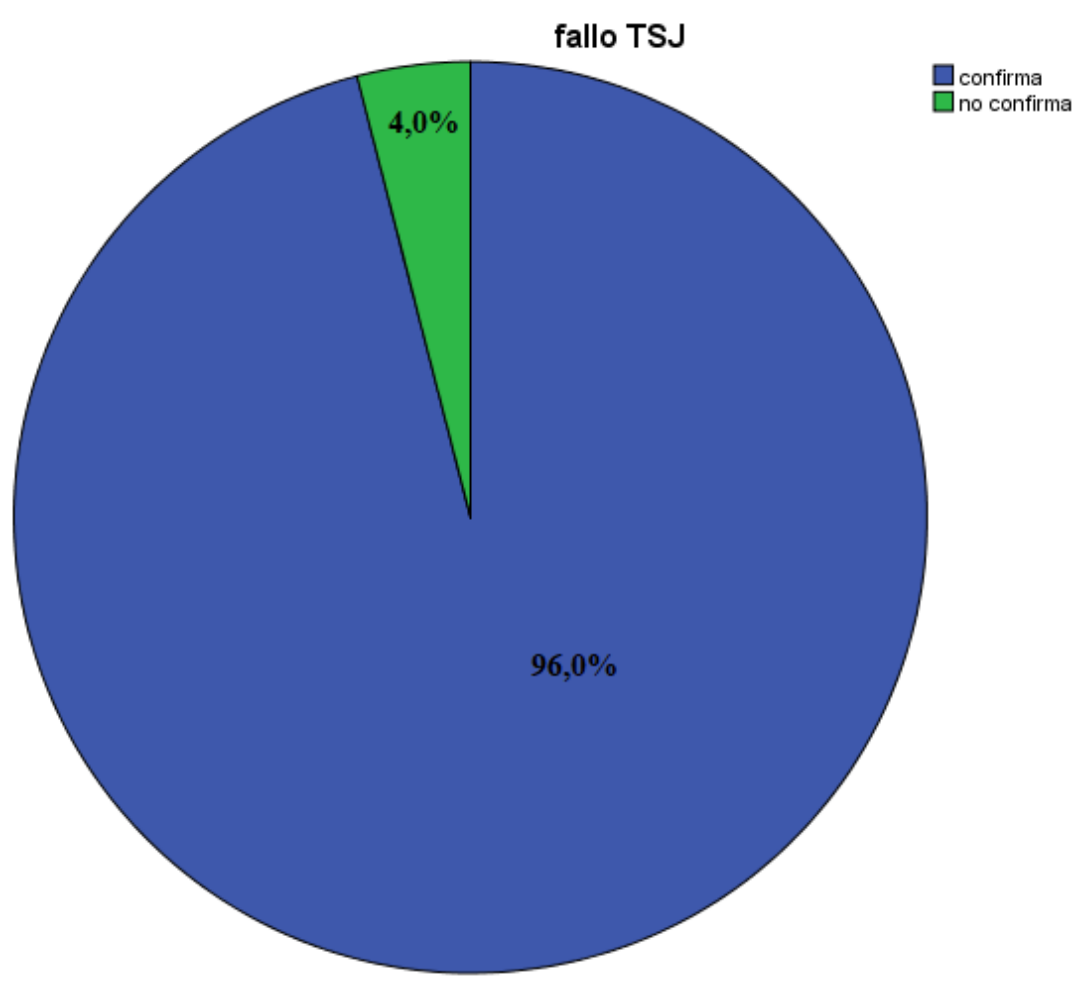

Gráfico 24: porcentaje de la confirmación/no confirmación del TSJ tras el recurso de apelación.

- Nos encontramos con que de los 125 veredictos recurridos, el TSJ confirma la resolución en 120 casos (96’0\%) y lo revoca en 5 (4’0\%), lo que nos indica que, con bastante probabilidad, un juez hubiera llegado a la misma conclusión y que el jurado no ha sido más severo. Mantiene el criterio en:

- 103 culpabilidades ( $85^{\prime} \% \%$ de las confirmaciones), 
○ 14 inculpabilidades (11'7\% de las confirmaciones),

$\circ$ en las restantes 3 absoluciones $(2 \% 5 \%$ de las confirmaciones).

- No confirma 4 veredictos de culpabilidad (3'7\%) y uno de no culpable (6'7\%). Como hemos dicho, ha confirmado las tres absoluciones por otros motivos, por lo que en este apartado la no confirmación es del $0 \%$.

A continuación se expone el cruce de variables entre el veredicto emitido por el jurado en el ámbito de la Audiencia Provincial y el fallo del Tribunal Superior de Justicia tras resolver el recurso de apelación.

Resumen de procesamiento de casos

\begin{tabular}{|c|c|c|c|c|c|c|}
\hline & \multicolumn{6}{|c|}{ Casos } \\
\hline & \multicolumn{2}{|c|}{ Válidos } & \multicolumn{2}{|c|}{ Perdidos } & \multicolumn{2}{|c|}{ Total } \\
\hline & $\mathrm{N}$ & Porcentaje & $\mathrm{N}$ & Porcentaje & $\mathrm{N}$ & Porcentaje \\
\hline veredicto en $\mathrm{AP} *$ fallo TSJ & 125 & $100,0 \%$ & 0 & $0,0 \%$ & 125 & $100,0 \%$ \\
\hline
\end{tabular}

Tabla cruzada veredicto en AP*fallo TSJ

Recuento

\begin{tabular}{|c|c|c|c|c|}
\hline & & \multicolumn{2}{|c|}{ fallo TSJ } & \multirow[b]{2}{*}{ Total } \\
\hline & & confirma & no confirma & \\
\hline \multirow[t]{3}{*}{ veredicto en $\mathrm{AP}$} & Culpable & 103 & 4 & 107 \\
\hline & no culpable & 14 & 1 & 15 \\
\hline & Abs & 3 & 0 & 3 \\
\hline \multicolumn{2}{|l|}{ Total } & 120 & 5 & 125 \\
\hline
\end{tabular}


Observamos que la mayoría de inculpabilidades se confirma y que incluso una de ellas es revocada, por lo que no se puede decir que el jurado haya actuado de forma errónea, ni que su tendencia a la culpabilidad sea más alta, al ser confirmados en su mayoría todo tipo de veredictos.

Tabla cruzada veredicto en AP*fallo TSJ

\begin{tabular}{|c|c|c|c|c|c|}
\hline & & & \multicolumn{2}{|c|}{ fallo TSJ } & \multirow[b]{2}{*}{ Total } \\
\hline & & & confirma & no confirma & \\
\hline \multirow[t]{12}{*}{ veredicto en AP } & Culpable & Recuento & 103 & 4 & 107 \\
\hline & & $\%$ dentro de veredicto en AP & $96,3 \%$ & $3,7 \%$ & $100,0 \%$ \\
\hline & & $\%$ dentro de fallo TSJ & $85,8 \%$ & $80,0 \%$ & $85,6 \%$ \\
\hline & & $\%$ del total & $82,4 \%$ & $3,2 \%$ & $85,6 \%$ \\
\hline & no culpable & Recuento & 14 & 1 & 15 \\
\hline & & $\%$ dentro de veredicto en $\mathrm{AP}$ & $93,3 \%$ & $6,7 \%$ & $100,0 \%$ \\
\hline & & $\%$ dentro de fallo TSJ & $11,7 \%$ & $20,0 \%$ & $12,0 \%$ \\
\hline & & $\%$ del total & $11,2 \%$ & $0,8 \%$ & $12,0 \%$ \\
\hline & Abs & Recuento & 3 & 0 & 3 \\
\hline & & $\%$ dentro de veredicto en AP & $100,0 \%$ & $0,0 \%$ & $100,0 \%$ \\
\hline & & $\%$ dentro de fallo TSJ & $2,5 \%$ & $0,0 \%$ & $2,4 \%$ \\
\hline & & $\%$ del total & $2,4 \%$ & $0,0 \%$ & $2,4 \%$ \\
\hline \multirow[t]{4}{*}{ Total } & & Recuento & 120 & 5 & 125 \\
\hline & & $\%$ dentro de veredicto en $\mathrm{AP}$ & $96,0 \%$ & $4,0 \%$ & $100,0 \%$ \\
\hline & & $\%$ dentro de fallo TSJ & $100,0 \%$ & $100,0 \%$ & $100,0 \%$ \\
\hline & & $\%$ del total & $96,0 \%$ & $4,0 \%$ & $100,0 \%$ \\
\hline
\end{tabular}




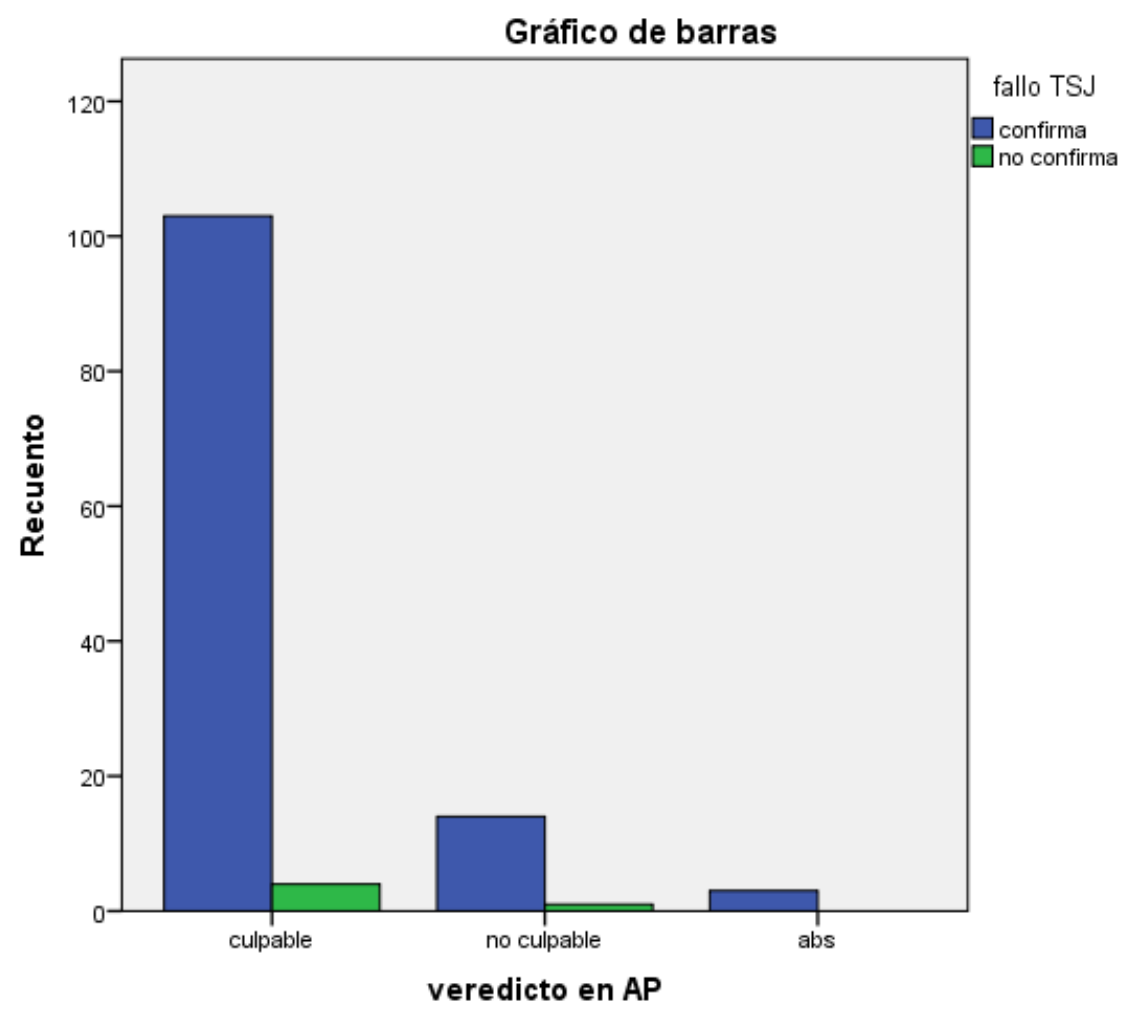

Gráfico 25: porcentajes para las variables cruzadas veredicto de la AP y fallo del recurso al TSJ.

\section{Resultados de las variables provincias y delito.}

En este punto, analizamos el nexo entre los dos tipos delictivos y las nueve provincias de la Comunidad, para observar la frecuencia de ambos delitos en cada una de ellas.

Resumen de procesamiento de casos

\begin{tabular}{|c|c|c|c|c|c|c|}
\hline & \multicolumn{6}{|c|}{ Casos } \\
\hline & \multicolumn{2}{|c|}{ Válidos } & \multicolumn{2}{|c|}{ Perdidos } & \multicolumn{2}{|c|}{ Total } \\
\hline & $\mathrm{N}$ & Porcentaje & $\mathrm{N}$ & Porcentaje & $\mathrm{N}$ & Porcentaje \\
\hline Delito $*$ Provincia & 235 & $100,0 \%$ & 0 & $0,0 \%$ & 235 & $100,0 \%$ \\
\hline
\end{tabular}


Tabla cruzada Provincia*Delito

\begin{tabular}{|c|c|c|c|c|c|}
\hline & & & \multicolumn{2}{|c|}{ Delito } & \multirow[b]{2}{*}{ Total } \\
\hline & & & homicidio & asesinato & \\
\hline \multirow[t]{22}{*}{ Provincia } & AV & Recuento & 5 & 9 & 14 \\
\hline & & $\%$ dentro de Provincia & $35,7 \%$ & $64,3 \%$ & $100,0 \%$ \\
\hline & & $\%$ dentro de Delito & $4,2 \%$ & $7,7 \%$ & $6,0 \%$ \\
\hline & & $\%$ del total & $2,1 \%$ & $3,8 \%$ & $6,0 \%$ \\
\hline & $\mathrm{BU}$ & Recuento & 26 & 30 & 56 \\
\hline & & $\%$ dentro de Provincia & $46,4 \%$ & $53,6 \%$ & $100,0 \%$ \\
\hline & & $\%$ dentro de Delito & $22,0 \%$ & $25,6 \%$ & $23,8 \%$ \\
\hline & & $\%$ del total & $11,1 \%$ & $12,8 \%$ & $23,8 \%$ \\
\hline & $\mathrm{LE}$ & Recuento & 31 & 26 & 57 \\
\hline & & $\%$ dentro de Provincia & $54,4 \%$ & $45,6 \%$ & $100,0 \%$ \\
\hline & & $\%$ dentro de Delito & $26,3 \%$ & $22,2 \%$ & $24,3 \%$ \\
\hline & & $\%$ del total & $13,2 \%$ & $11,1 \%$ & $24,3 \%$ \\
\hline & $\mathrm{P}$ & Recuento & 7 & 6 & 13 \\
\hline & & $\%$ dentro de Provincia & $53,8 \%$ & $46,2 \%$ & $100,0 \%$ \\
\hline & & $\%$ dentro de Delito & $5,9 \%$ & $5,1 \%$ & $5,5 \%$ \\
\hline & & $\%$ del total & $3,0 \%$ & $2,6 \%$ & $5,5 \%$ \\
\hline & $\mathrm{SA}$ & Recuento & 13 & 6 & 19 \\
\hline & & $\%$ dentro de Provincia & $68,4 \%$ & $31,6 \%$ & $100,0 \%$ \\
\hline & & $\%$ dentro de Delito & $11,0 \%$ & $5,1 \%$ & $8,1 \%$ \\
\hline & & $\%$ del total & $5,5 \%$ & $2,6 \%$ & $8,1 \%$ \\
\hline & SG & Recuento & 8 & 6 & 14 \\
\hline & & $\%$ dentro de Provincia & $57,1 \%$ & $42,9 \%$ & $100,0 \%$ \\
\hline
\end{tabular}




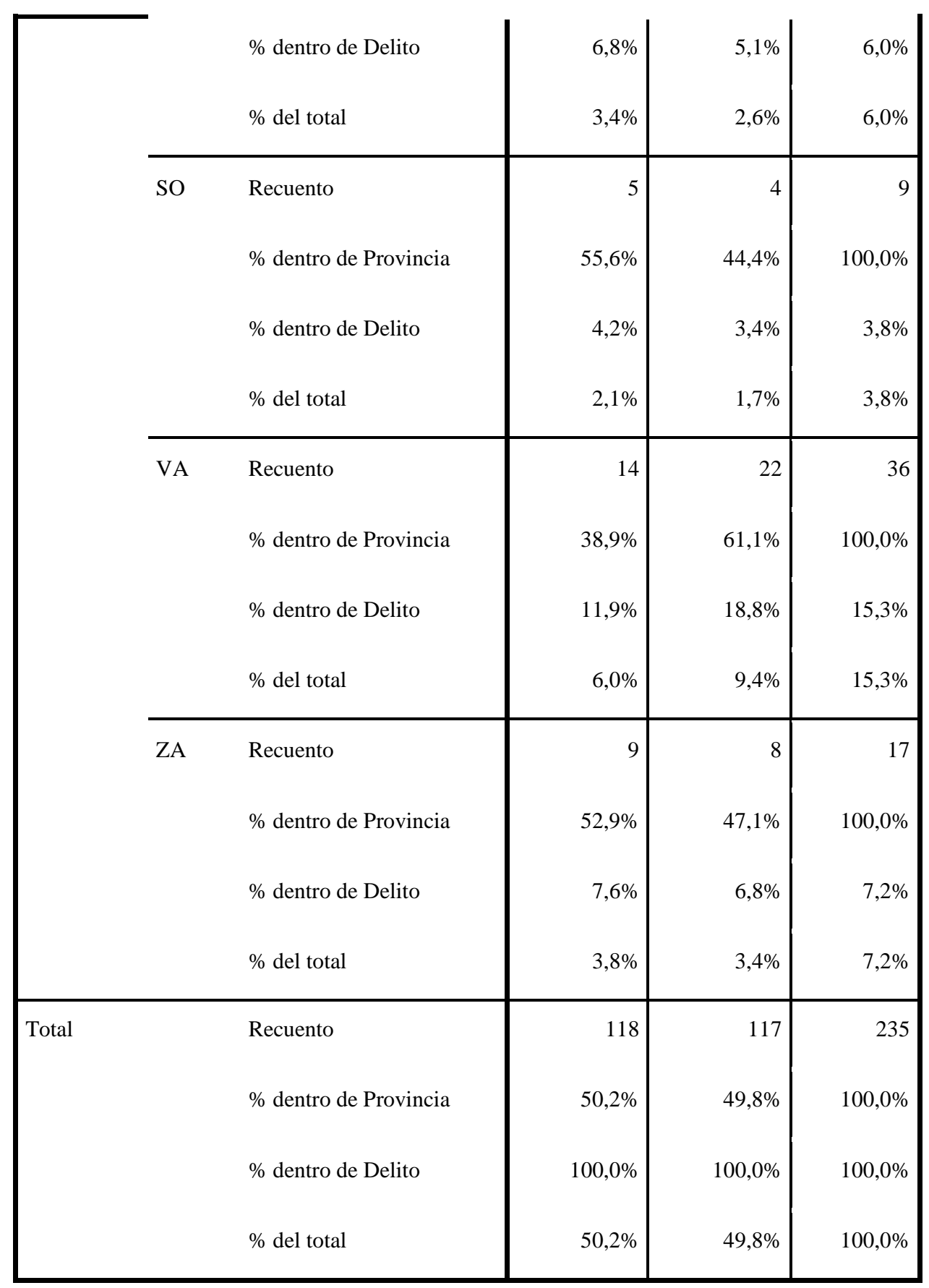

- Si observamos los delitos por separado en cada provincia, al analizar cuáles tienen mayor índice de homicidios, comprobamos que son:

○ León, con 31 homicidios y 26 asesinatos,

- Salamanca, con una diferencia muy significativa, ya que son 13 homicidios (el 68,4\%), y 6 asesinatos (31'6\%), es decir, 
más del doble de los homicidios respecto a los asesinatos cometidos en esa provincia,

- Segovia, con el $57^{\prime} 1 \%$ de homicidios y el $42 \% \%$ de asesinatos.

- Las provincias con más asesinatos, en proporción a los delitos contra la vida en general dentro de su territorio, son:

- Ávila, con 5 homicidios $(35,7 \%)$ frente a 9 asesinatos $(64,3 \%)$,

○ Burgos, donde la diferencia es de 26 homicidios $(46,4 \%)$ por 30 asesinatos $(53,6 \%)$,

- Valladolid, la que mayor distancia muestra, donde se han juzgado 14 homicidios $(38,9 \%)$ y 22 asesinatos $(61,1 \%)$.

- El resto de provincias (Palencia, Soria y Zamora) presenta unos números muy similares para los dos delitos, casi parejos.

- La provincia, en proporción, con más homicidios es León (31, el $26,3 \%$, es decir, más de la cuarta parte del total de los enjuiciados en toda la Comunidad de Castilla y León) y las que menos, Ávila y Soria, con 5 cada una, lo que representa un 4,2\%, respectivamente.

- En la que más asesinatos se han juzgado, también hablando de manera proporcional, es Burgos, con 30, también más de una cuarta parte del total de los asesinatos, el 25,6\%. La que menos de nuevo es Soria, donde ha habido solo 4, el 3,4\%. 


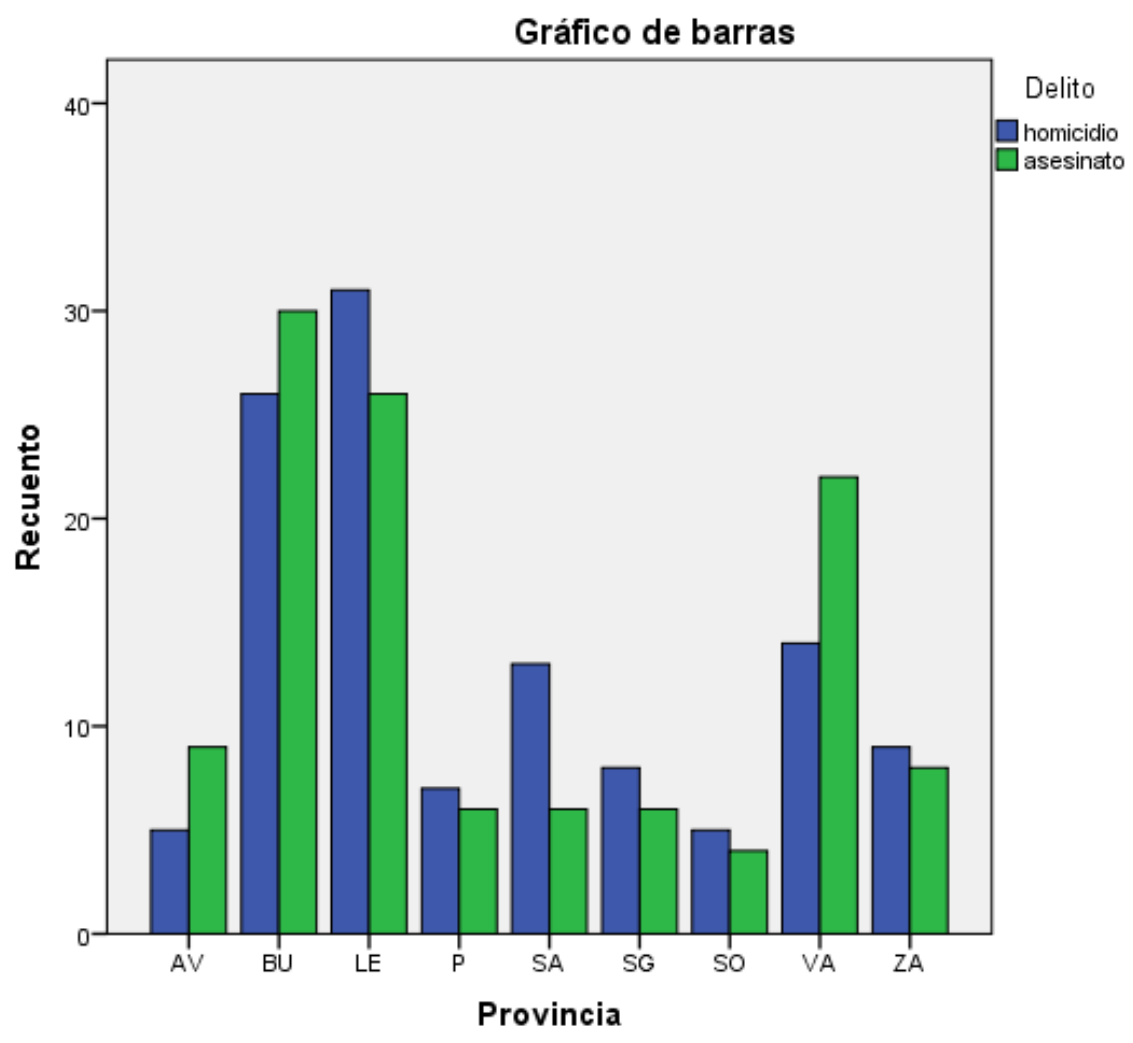

Gráfico 26: porcentajes para las variables cruzadas delito y provincia.

\section{Resultados de las variables recurso y provincias.}

Cruzamos ahora estas dos variables con el objetivo de conocer si en cada una de las provincias se recurre más o menos. Por territorios, donde en más ocasiones se ha recurrido guarda proporción con las tres en las que más casos se han enjuiciado, Burgos, León y Valladolid, por ese orden (el 64\% del total de los recursos lo suman entre esas tres provincias).

\section{Estadísticos}

provincia

\begin{tabular}{|ll|r|}
\hline N & Válido & 125 \\
& Perdidos & 0 \\
\hline
\end{tabular}


Provincia

\begin{tabular}{|c|c|c|c|c|c|}
\hline & & Frecuencia & Porcentaje & Porcentaje válido & $\begin{array}{l}\text { Porcentaje } \\
\text { acumulado }\end{array}$ \\
\hline Válido & $\mathrm{AV}$ & 6 & 4,8 & 4,8 & 4,8 \\
\hline & $\mathrm{BU}$ & 28 & 22,4 & 22,4 & 27,2 \\
\hline & LE & 28 & 22,4 & 22,4 & 49,6 \\
\hline & $\mathrm{P}$ & 7 & 5,6 & 5,6 & 55,2 \\
\hline & SA & 9 & 7,2 & 7,2 & 62,4 \\
\hline & SG & 7 & 5,6 & 5,6 & 68,0 \\
\hline & SO & 5 & 4,0 & 4,0 & 72,0 \\
\hline & VA & 24 & 19,2 & 19,2 & 91,2 \\
\hline & $\mathrm{ZA}$ & 11 & 8,8 & 8,8 & 100,0 \\
\hline & Total & 125 & 100,0 & 100,0 & \\
\hline
\end{tabular}

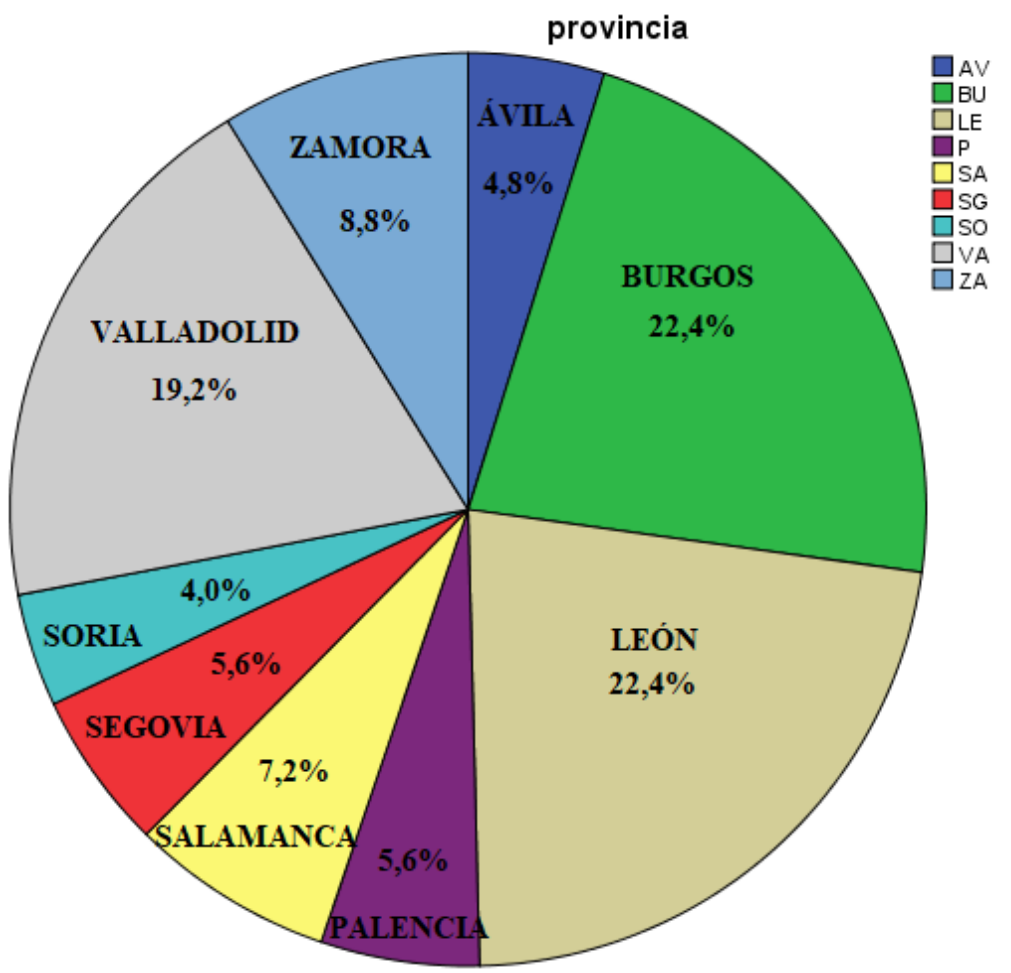

Gráfico 27: porcentajes de la variable recurso por provincias. 
4. Resultados de las variables cruzadas fallo del recurso de apelación al $\underline{\text { TSJ y provincias. }}$

Procedemos ahora a conectar el fallo del TSJ tras resolver la apelación, con los recursos interpuestos al recurrir las resoluciones de cada una de las Audiencias Provinciales.

Resumen de procesamiento de casos

\begin{tabular}{|c|c|c|c|c|c|c|}
\hline & \multicolumn{6}{|c|}{ Casos } \\
\hline & \multicolumn{2}{|c|}{ Válidos } & \multicolumn{2}{|c|}{ Perdidos } & \multicolumn{2}{|c|}{ Total } \\
\hline & $\mathrm{N}$ & Porcentaje & $\mathrm{N}$ & Porcentaje & $\mathrm{N}$ & Porcentaje \\
\hline fallo TSJ $*$ provincia & 125 & $100,0 \%$ & 0 & $0,0 \%$ & 125 & $100,0 \%$ \\
\hline
\end{tabular}

Recuento

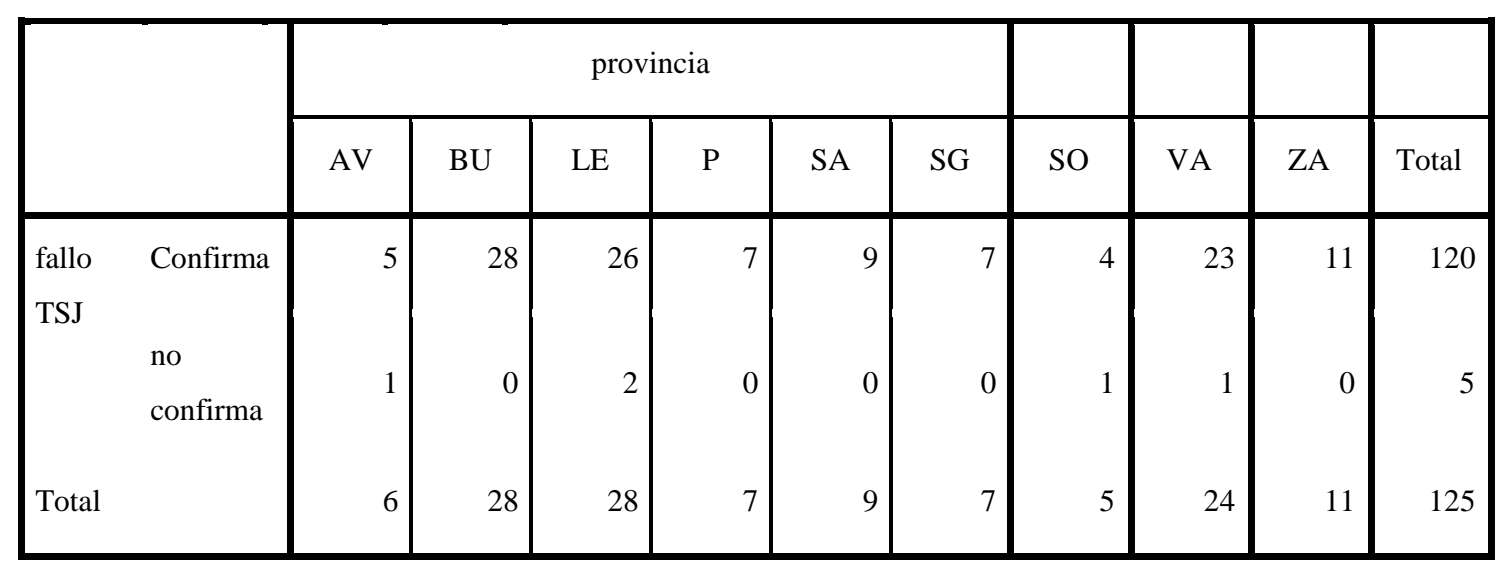

- Las no confirmadas han sido:

○ 1 en Ávila,

○ 2 en León,

○ 1 en Soria,

○ 1 en Valladolid. 
El resto de las provincias ha tenido un $100 \%$ de confirmación, donde cabe destacar Burgos, provincia que, igual que León, más recursos ha presentado (el $22{ }^{\prime} 4 \%$ de toda la comunidad) y donde los 28 han sido confirmados.

- La confirmación ha sido en:

○ 5 de 6 sentencias en Ávila (el 4'8\% del total de veredictos recurridos en Castilla y León),

○ 28 en Burgos $\left(22^{\prime} 4 \%\right)$,

○ 26 de 28 en León $\left(222^{\prime} \%\right.$ ),

○ 7 en Palencia $(5,6 \%)$,

○ 9 en Salamanca $\left(7^{\prime} 2 \%\right)$,

○ 7 en Segovia $(5,6 \%)$,

○ 4 de 5 recurridas en Soria (4’0\%),

○ 23 de 24 en Valladolid (19'2\%),

- 11 de Zamora (8'8\%).

Resumen de procesamiento de casos

\begin{tabular}{|c|c|c|c|c|c|c|}
\hline & \multicolumn{6}{|c|}{ Casos } \\
\hline & \multicolumn{2}{|c|}{ Válidos } & \multicolumn{2}{|c|}{ Perdidos } & \multicolumn{2}{|c|}{ Total } \\
\hline & $\mathrm{N}$ & Porcentaje & $\mathrm{N}$ & Porcentaje & $\mathrm{N}$ & Porcentaje \\
\hline provincia $*$ fallo TSJ & 125 & $100,0 \%$ & 0 & $0,0 \%$ & 125 & $100,0 \%$ \\
\hline
\end{tabular}

Tabla cruzada provincia*fallo TSJ

\begin{tabular}{|ll|r|r|r|}
\hline \multirow{2}{*}{} & & \multicolumn{2}{|c|}{ fallo TSJ } & \\
\cline { 3 - 4 } & & confirma & no confirma & \multirow{2}{*}{ Total } \\
\hline provincia & AV $\quad$ Recuento & 5 & 1 & 6 \\
\hline
\end{tabular}




\begin{tabular}{|c|c|c|c|c|}
\hline & $\%$ dentro de provincia & $83,3 \%$ & $16,7 \%$ & $100,0 \%$ \\
\hline & $\%$ dentro de fallo TSJ & $4,2 \%$ & $20,0 \%$ & $4,8 \%$ \\
\hline & $\%$ del total & $4,0 \%$ & $0,8 \%$ & $4,8 \%$ \\
\hline $\mathrm{BU}$ & Recuento & 28 & 0 & 28 \\
\hline & $\%$ dentro de provincia & $100,0 \%$ & $0,0 \%$ & $100,0 \%$ \\
\hline & $\%$ dentro de fallo TSJ & $23,3 \%$ & $0,0 \%$ & $22,4 \%$ \\
\hline & $\%$ del total & $22,4 \%$ & $0,0 \%$ & $22,4 \%$ \\
\hline $\mathrm{LE}$ & Recuento & 26 & 2 & 28 \\
\hline & $\%$ dentro de provincia & $92,9 \%$ & $7,1 \%$ & $100,0 \%$ \\
\hline & $\%$ dentro de fallo TSJ & $21,7 \%$ & $40,0 \%$ & $22,4 \%$ \\
\hline & $\%$ del total & $20,8 \%$ & $1,6 \%$ & $22,4 \%$ \\
\hline $\mathrm{P}$ & Recuento & 7 & 0 & 7 \\
\hline & $\%$ dentro de provincia & $100,0 \%$ & $0,0 \%$ & $100,0 \%$ \\
\hline & $\%$ dentro de fallo TSJ & $5,8 \%$ & $0,0 \%$ & $5,6 \%$ \\
\hline & $\%$ del total & $5,6 \%$ & $0,0 \%$ & $5,6 \%$ \\
\hline SA & Recuento & 9 & 0 & 9 \\
\hline & $\%$ dentro de provincia & $100,0 \%$ & $0,0 \%$ & $100,0 \%$ \\
\hline & $\%$ dentro de fallo TSJ & $7,5 \%$ & $0,0 \%$ & $7,2 \%$ \\
\hline & $\%$ del total & $7,2 \%$ & $0,0 \%$ & $7,2 \%$ \\
\hline SG & Recuento & 7 & 0 & 7 \\
\hline & $\%$ dentro de provincia & $100,0 \%$ & $0,0 \%$ & $100,0 \%$ \\
\hline & $\%$ dentro de fallo TSJ & $5,8 \%$ & $0,0 \%$ & $5,6 \%$ \\
\hline & $\%$ del total & $5,6 \%$ & $0,0 \%$ & $5,6 \%$ \\
\hline SO & Recuento & 4 & 1 & 5 \\
\hline
\end{tabular}




\begin{tabular}{|c|c|c|c|c|c|}
\hline & & $\%$ dentro de provincia & $80,0 \%$ & $20,0 \%$ & $100,0 \%$ \\
\hline & & $\%$ dentro de fallo TSJ & $3,3 \%$ & $20,0 \%$ & $4,0 \%$ \\
\hline & & $\%$ del total & $3,2 \%$ & $0,8 \%$ & $4,0 \%$ \\
\hline & VA & Recuento & 23 & 1 & 24 \\
\hline & & $\%$ dentro de provincia & $95,8 \%$ & $4,2 \%$ & $100,0 \%$ \\
\hline & & $\%$ dentro de fallo TSJ & $19,2 \%$ & $20,0 \%$ & $19,2 \%$ \\
\hline & & $\%$ del total & $18,4 \%$ & $0,8 \%$ & $19,2 \%$ \\
\hline & $\mathrm{ZA}$ & Recuento & 11 & 0 & 11 \\
\hline & & $\%$ dentro de provincia & $100,0 \%$ & $0,0 \%$ & $100,0 \%$ \\
\hline & & $\%$ dentro de fallo TSJ & $9,2 \%$ & $0,0 \%$ & $8,8 \%$ \\
\hline & & $\%$ del total & $8,8 \%$ & $0,0 \%$ & $8,8 \%$ \\
\hline Total & & Recuento & 120 & 5 & 125 \\
\hline & & $\%$ dentro de provincia & $96,0 \%$ & $4,0 \%$ & $100,0 \%$ \\
\hline & & $\%$ dentro de fallo TSJ & $100,0 \%$ & $100,0 \%$ & $100,0 \%$ \\
\hline & & $\%$ del total & $96,0 \%$ & $4,0 \%$ & $100,0 \%$ \\
\hline
\end{tabular}




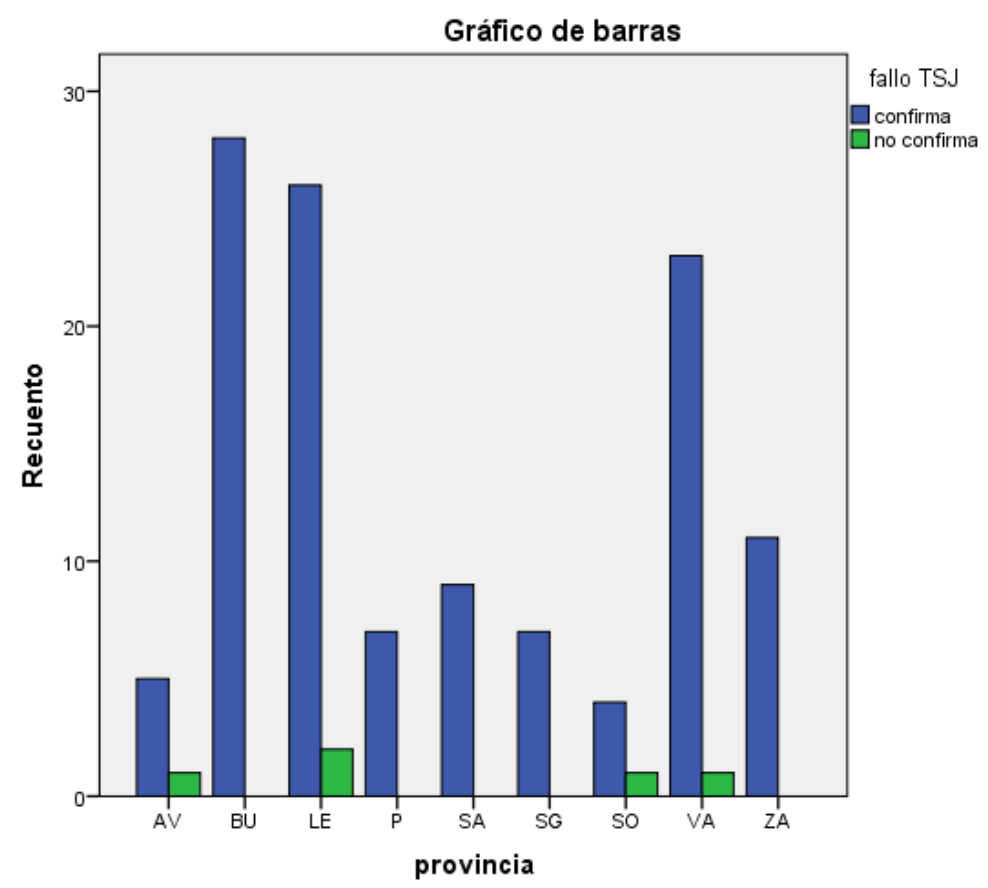

Gráfico 28: porcentajes para las variables cruzadas provincias y recurso al TSJ.

5. Resultados para la variable recurso de casación al Tribunal Supremo.

En este punto, analizamos cuántas de las sentencias iniciales se recurren en casación al TS y que se detallarán en el siguiente apartado. De los 125 veredictos que se habían recurrido en apelación, 48 (38,4\%) se recurren posteriormente en casación al Supremo y 77 (61,6\%) no se recurren. El porcentaje de resoluciones recurridas baja con respecto al de recursos de apelación. También hay que tener en cuenta, como ya se ha comentado, que algunas de las últimas pueden haber sido recurridas aunque al establecer el final del periodo en 2017 ya no se hayan incluido.

Estadísticos

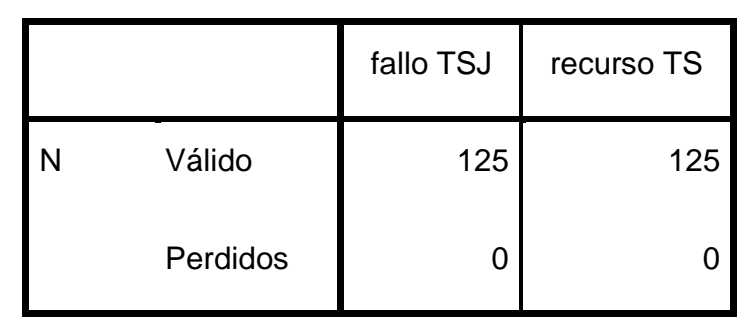


recurso TS

\begin{tabular}{|r|r|r|r|r|}
\hline & Frecuencia & Porcentaje & Porcentaje válido & $\begin{array}{r}\text { Porcentaje } \\
\text { acumulado }\end{array}$ \\
\hline Válido recurrida & 48 & 38,4 & 38,4 & 38,4 \\
& & & 61,6 & 100,0 \\
& 77 & 100,0 & 100,0 & \\
\hline
\end{tabular}

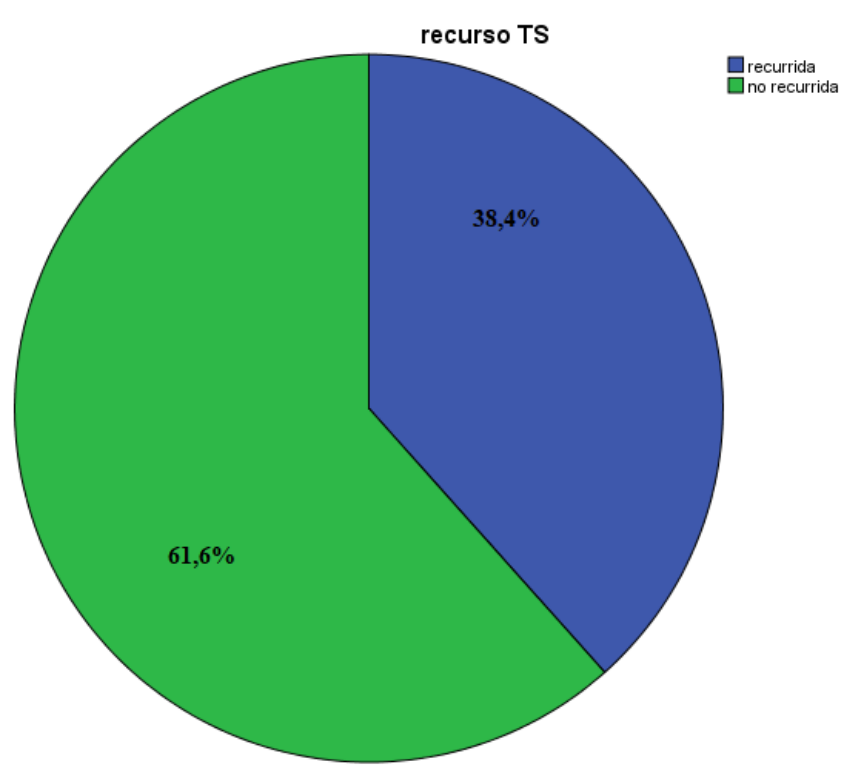

Gráfico 29: porcentaje de la variable recurso de casación al TS.

6.1.3. Resultados respecto a los recursos de casación ante el Tribunal Supremo.

\section{$\underline{1 .}$ Resultados de la variable recurso al TS.}

Los datos del examen de las sentencias arrojan un resultado de 48 veredictos recurridos al Tribunal Supremo, de los que se confirman 45 $(93,8 \%)$ y se anulan $3(6 \% 3 \%)$. Vemos que la mayoría de las sentencias confirman las dictadas en primera instancia vinculadas al veredicto emitido por el jurado. 
Estadísticos

fallo TS

\begin{tabular}{|ll|r|}
\hline $\mathrm{N}$ & Válido & 48 \\
& Perdidos & 0 \\
\hline
\end{tabular}

fallo TS

\begin{tabular}{|c|c|c|c|c|c|}
\hline & & Frecuencia & Porcentaje & Porcentaje válido & $\begin{array}{l}\text { Porcentaje } \\
\text { acumulado }\end{array}$ \\
\hline \multirow[t]{3}{*}{ Válido } & confirma & 45 & 93,8 & 93,8 & 93,8 \\
\hline & no confirma & 3 & 6,3 & 6,3 & 100,0 \\
\hline & Total & 48 & 100,0 & 100,0 & \\
\hline
\end{tabular}

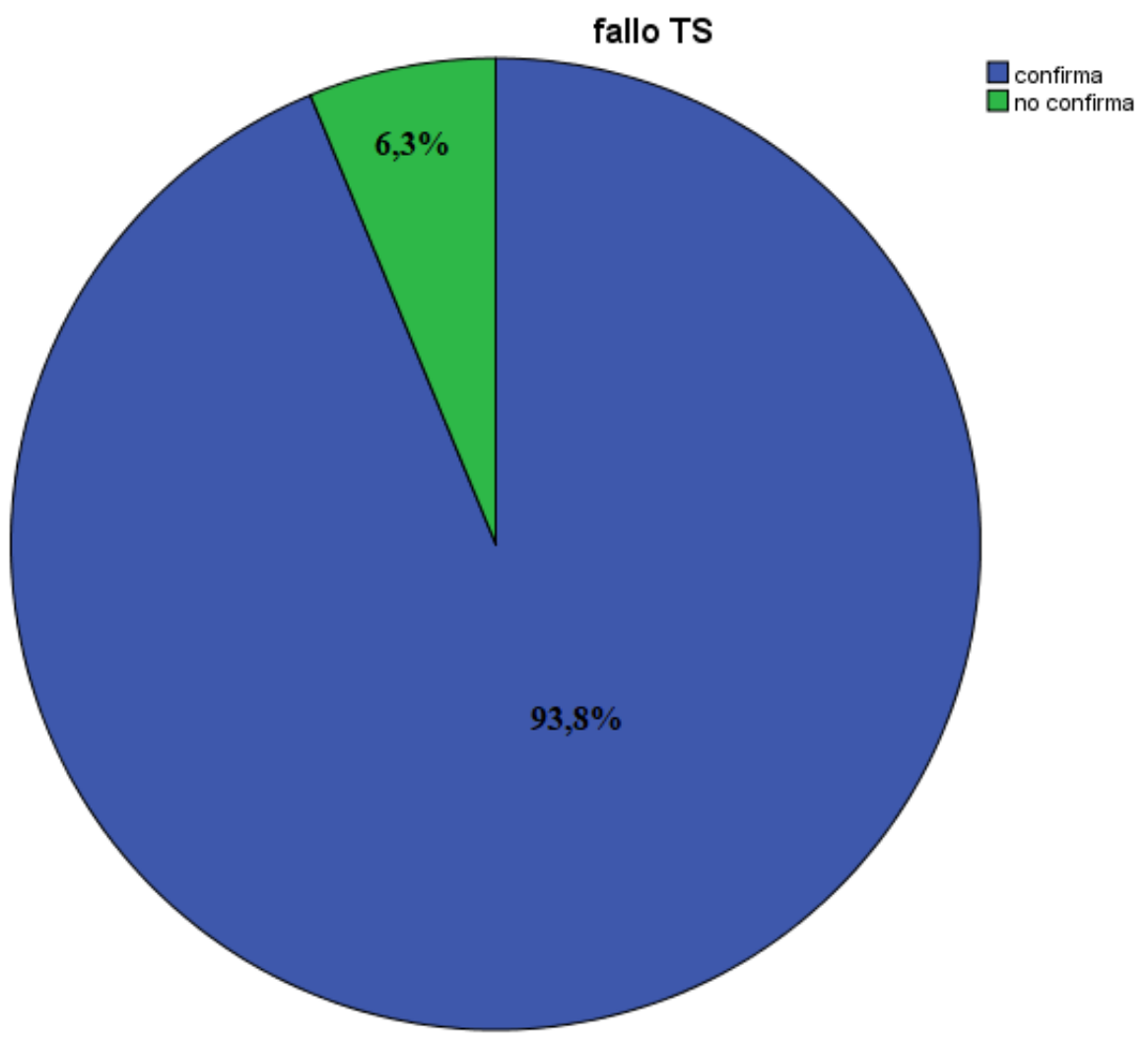

Gráfico 30: porcentaje de resoluciones confirmadas/no confirmadas en casación por el TS. 


\section{Correspondencia entre las variables veredicto y recurso al TS.}

Una vez visto el número de sentencias recurridas, relacionamos ahora en cuántas se ha condenado al acusado, por el veredicto de culpabilidad, y en cuántas ha sido absuelto, tras emitir el jurado veredicto de no culpabilidad.

Resumen de procesamiento de casos

\begin{tabular}{|c|c|c|c|c|c|c|}
\hline & \multicolumn{6}{|c|}{ Casos } \\
\hline & \multicolumn{2}{|c|}{ Válidos } & \multicolumn{2}{|c|}{ Perdidos } & \multicolumn{2}{|c|}{ Total } \\
\hline & $\mathrm{N}$ & Porcentaje & $\mathrm{N}$ & Porcentaje & $\mathrm{N}$ & Porcentaje \\
\hline veredicto en $\mathrm{AP} *$ fallo $\mathrm{TS}$ & 48 & $100,0 \%$ & 0 & $0,0 \%$ & 48 & $100,0 \%$ \\
\hline
\end{tabular}

Tabla cruzada veredicto en AP*fallo TS

Recuento

\begin{tabular}{|c|c|c|c|c|}
\hline & \multicolumn{2}{|c|}{ fallo TS } & \multirow[b]{2}{*}{ Total } \\
\hline & & confirma & no confirma & \\
\hline \multirow[t]{2}{*}{ veredicto en AP } & culpable & 38 & 1 & 39 \\
\hline & no culpable & 7 & 2 & 9 \\
\hline Total & & 45 & 3 & 48 \\
\hline
\end{tabular}

- Ninguna de las sentencias del TSJ que revocaron las sentencias de las Audiencias fueron recurridas, por lo que todas las del TSJ analizadas en este apartado fueron de confirmación, de modo que comparamos los veredictos emitidos por el jurado con la resolución de los recursos de casación en el Supremo.

- 39 de las sentencias recurridas condenaron al acusado tras el veredicto de culpabilidad. De ellas, el TS confirma 38 (97'4\%) y no confirma $1\left(2{ }^{\prime} 6 \%\right)$. 
- De las 9 sentencias absolutorias que siguieron el veredicto de inculpabilidad, el TS confirma 7 de ellas $\left(77^{\prime} 8 \%\right)$ y no confirma 2 $(22 ’ 2 \%)$.

Tabla cruzada veredicto en AP*fallo TS

\begin{tabular}{|c|c|c|c|c|c|}
\hline & & & \multicolumn{2}{|c|}{ fallo TS } & \multirow[b]{2}{*}{ Total } \\
\hline & & & confirma & no confirma & \\
\hline \multirow[t]{8}{*}{ veredicto en $\mathrm{AP}$} & culpable & Recuento & 38 & 1 & 38 \\
\hline & & $\%$ dentro de veredicto en AP & $97,4 \%$ & $2,6 \%$ & $100,0 \%$ \\
\hline & & $\%$ dentro de fallo TS & $84,4 \%$ & $33,3 \%$ & $81,3 \%$ \\
\hline & & $\%$ del total & $79,2 \%$ & $2,1 \%$ & $81,3 \%$ \\
\hline & no culpable & Recuento & 7 & 2 & 9 \\
\hline & & $\%$ dentro de veredicto en AP & $77,8 \%$ & $22,2 \%$ & $100,0 \%$ \\
\hline & & $\%$ dentro de fallo TS & $15,6 \%$ & $66,7 \%$ & $18,8 \%$ \\
\hline & & $\%$ del total & $14,6 \%$ & $4,2 \%$ & $18,8 \%$ \\
\hline \multirow[t]{4}{*}{ Total } & & Recuento & 45 & 3 & 48 \\
\hline & & $\%$ dentro de veredicto en $\mathrm{AP}$ & $93,8 \%$ & $6,3 \%$ & $100,0 \%$ \\
\hline & & $\%$ dentro de fallo TS & $100,0 \%$ & $100,0 \%$ & $100,0 \%$ \\
\hline & & $\%$ del total & $93,8 \%$ & $6,3 \%$ & $100,0 \%$ \\
\hline
\end{tabular}




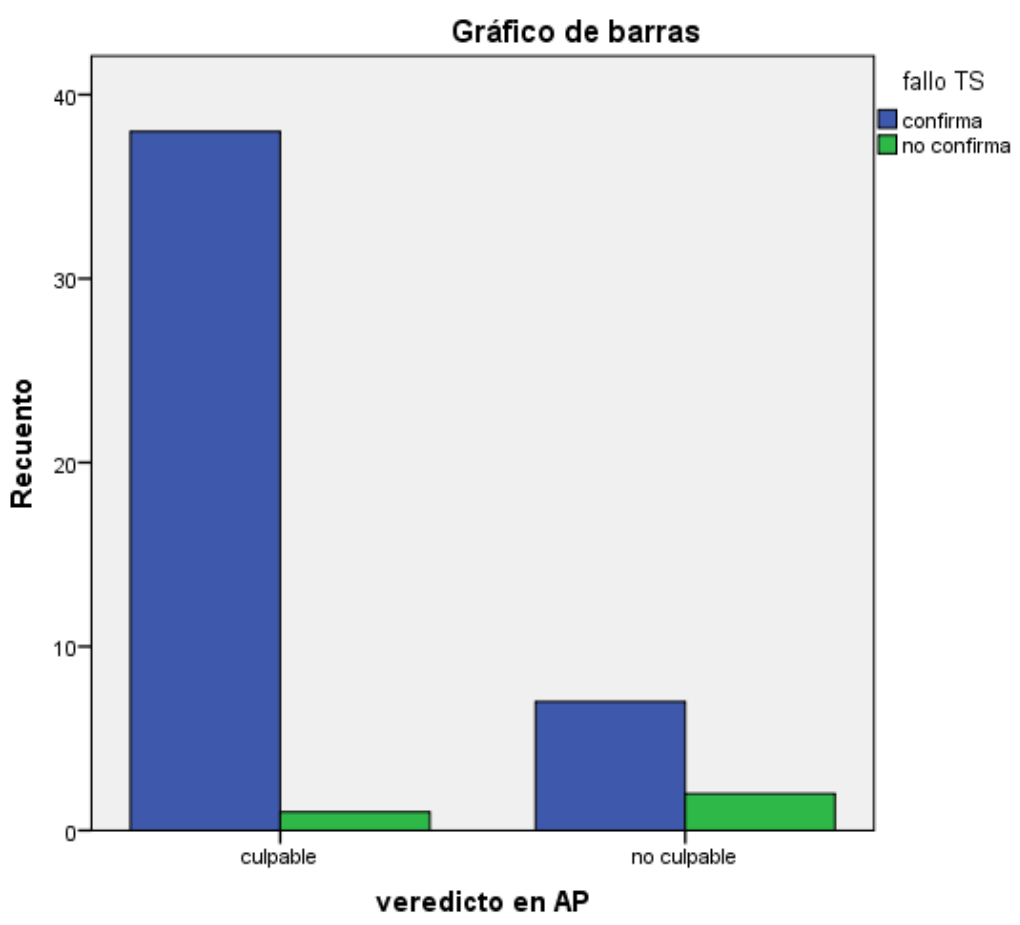

Gráfico 31: porcentajes para las variables cruzadas veredicto AP y recurso de casación al TS.

\section{Correspondencia entre las variables delito y recurso al TS.}

Comprobamos ahora qué porcentaje de las resoluciones recurridas en casación al Supremo son de homicidio y cuántas son en casos de asesinato.

\begin{tabular}{|c|c|c|c|c|c|c|}
\hline & \multicolumn{6}{|c|}{ Casos } \\
\hline & \multicolumn{2}{|c|}{ Válidos } & \multicolumn{2}{|c|}{ Perdidos } & \multicolumn{2}{|c|}{ Total } \\
\hline & $\mathrm{N}$ & Porcentaje & $\mathrm{N}$ & Porcentaje & $\mathrm{N}$ & Porcentaje \\
\hline delito $*$ fallo TS & 48 & $100,0 \%$ & 0 & $0,0 \%$ & 48 & $100,0 \%$ \\
\hline
\end{tabular}


Tabla cruzada delito*fallo TS

Recuento

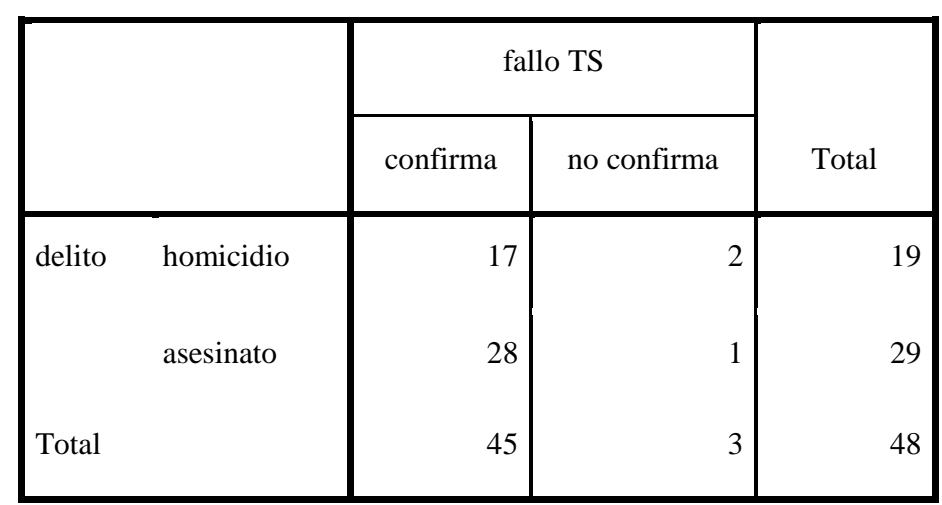

- Por delitos en total, se han recurrido más asesinatos, 29 (60’4\%), que homicidios, 19 (39'6\%).

- Se confirman 28 asesinatos (96'6\%) por tan solo 1 no confirmado (3'2\%).

- En cuanto a los homicidios, las sentencias confirmaron 17 $\left(89^{\prime} 5 \%\right)$ y revocaron $2\left(10^{\prime} 5 \%\right)$. 
Tabla cruzada delito*fallo TS

\begin{tabular}{|c|c|c|c|c|c|}
\hline & & & \multicolumn{2}{|c|}{ fallo TS } & \multirow[b]{2}{*}{ Total } \\
\hline & & & confirma & no confirma & \\
\hline \multirow[t]{8}{*}{ delito } & Homicidio & Recuento & 17 & 2 & 19 \\
\hline & & $\%$ dentro de delito & $89,5 \%$ & $10,5 \%$ & $100,0 \%$ \\
\hline & & $\%$ dentro de fallo TS & $37,8 \%$ & $66,7 \%$ & $39,6 \%$ \\
\hline & & $\%$ del total & $35,4 \%$ & $4,2 \%$ & $39,6 \%$ \\
\hline & Asesinato & Recuento & 28 & 1 & 29 \\
\hline & & $\%$ dentro de delito & $96,6 \%$ & $3,4 \%$ & $100,0 \%$ \\
\hline & & $\%$ dentro de fallo TS & $62,2 \%$ & $33,3 \%$ & $60,4 \%$ \\
\hline & & $\%$ del total & $58,3 \%$ & $2,1 \%$ & $60,4 \%$ \\
\hline \multirow[t]{4}{*}{ Total } & & Recuento & 45 & 3 & 48 \\
\hline & & $\%$ dentro de delito & $93,8 \%$ & $6,3 \%$ & $100,0 \%$ \\
\hline & & $\%$ dentro de fallo TS & $100,0 \%$ & $100,0 \%$ & $100,0 \%$ \\
\hline & & $\%$ del total & $93,8 \%$ & $6,3 \%$ & $100,0 \%$ \\
\hline
\end{tabular}

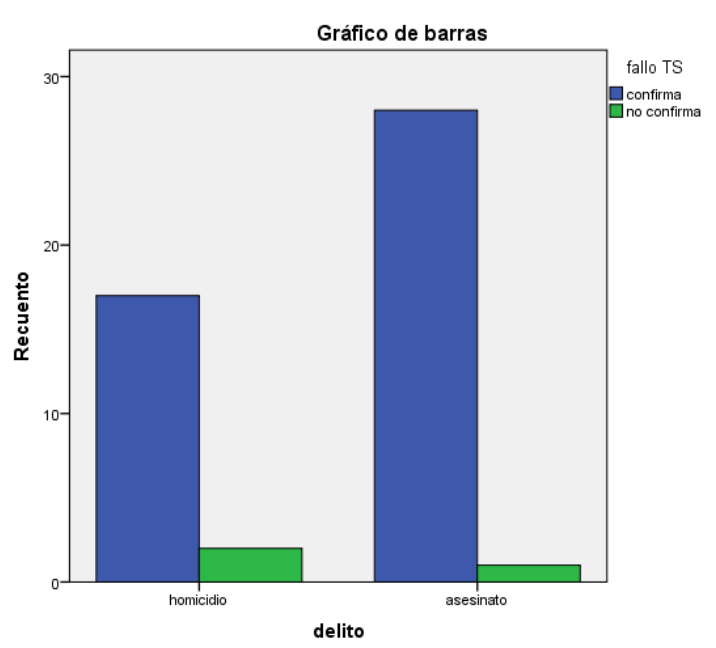

Gráfico 32: porcentajes para las variables cruzadas delito y recurso de casación al TS. 
4. Resultados para las variables sexo y fallo del recurso al TS.

Por último, correlacionamos el fallo de las sentencias dictadas por el Supremo en casación, con el sexo del recurrente para observar:

- quiénes recurren más o si lo hacen por igual,

- si hay alguna diferencia al confirmar o revocar, o si por el contrario, este aspecto no tiene relevancia.

Resumen de procesamiento de casos

\begin{tabular}{|c|c|c|c|c|c|c|}
\hline & \multicolumn{6}{|c|}{ Casos } \\
\hline & \multicolumn{2}{|c|}{ Válidos } & \multicolumn{2}{|c|}{ Perdidos } & \multicolumn{2}{|c|}{ Total } \\
\hline & $\mathrm{N}$ & Porcentaje & $\mathrm{N}$ & Porcentaje & $\mathrm{N}$ & Porcentaje \\
\hline sexo $*$ fallo TS & 48 & $100,0 \%$ & 0 & $0,0 \%$ & 48 & $100,0 \%$ \\
\hline
\end{tabular}

Tabla cruzada sexo*fallo TS

Recuento

\begin{tabular}{|rr|r|r|r|}
\hline \multirow{2}{*}{} & \multicolumn{2}{|c|}{ fallo TS } & \multirow{2}{*}{ Total } \\
\cline { 2 - 4 } & confirma & no confirma & \multirow{2}{*}{ Tota } \\
\hline sexo & Hombre & 37 & 3 & 40 \\
& mujer & 8 & 0 & 8 \\
\hline
\end{tabular}

- En el global de las sentencias, los hombres han recurrido más que las mujeres, ellos en 40 ocasiones (83'3\%), con un porcentaje mucho más amplio, por 8 recursos de ellas $\left(16^{\prime} 7 \%\right)$.

- Por sexos, en el caso de las mujeres, todas las resoluciones han sido confirmadas. 
- En el caso de los hombres, los 3 veredictos anulados por el TS han sido a 1 condenado y 2 absueltos (7'5\% dentro de las recurridas por hombres), mientras que 39 de los veredictos que condenan o absuelven a hombres, fueron confirmados $(92,5 \%)$.

Tabla cruzada fallo TS*sexo

\begin{tabular}{|c|c|c|c|c|c|}
\hline & & & \multicolumn{2}{|c|}{ Sexo } & \multirow[b]{2}{*}{ Total } \\
\hline & & & hombre & mujer & \\
\hline \multirow[t]{8}{*}{ fallo TS } & Confirma & Recuento & 37 & 8 & 45 \\
\hline & & $\%$ dentro de fallo TS & $82,2 \%$ & $17,8 \%$ & $100,0 \%$ \\
\hline & & $\%$ dentro de sexo & $92,5 \%$ & $100,0 \%$ & $93,8 \%$ \\
\hline & & $\%$ del total & $77,1 \%$ & $16,7 \%$ & $93,8 \%$ \\
\hline & no confirma & Recuento & 3 & 0 & 3 \\
\hline & & $\%$ dentro de fallo TS & $100,0 \%$ & $0,0 \%$ & $100,0 \%$ \\
\hline & & $\%$ dentro de sexo & $7,5 \%$ & $0,0 \%$ & $6,3 \%$ \\
\hline & & $\%$ del total & $6,3 \%$ & $0,0 \%$ & $6,3 \%$ \\
\hline \multirow[t]{4}{*}{ Total } & & Recuento & 40 & 8 & 48 \\
\hline & & $\%$ dentro de fallo TS & $83,3 \%$ & $16,7 \%$ & $100,0 \%$ \\
\hline & & $\%$ dentro de sexo & $100,0 \%$ & $100,0 \%$ & $100,0 \%$ \\
\hline & & $\%$ del total & $83,3 \%$ & $16,7 \%$ & $100,0 \%$ \\
\hline
\end{tabular}




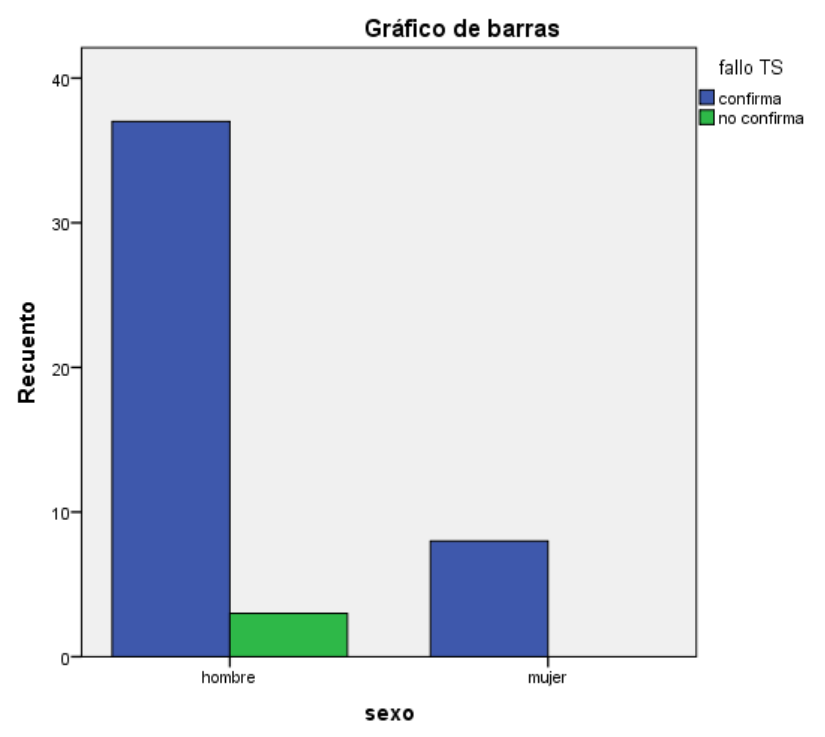

Gráfico 33: porcentajes para las variables cruzadas sexo y recurso de casación al TS.

\subsection{Valoración de los resultados.}

Tras observar los datos estadísticos expuestos para cada una de las variables estudiadas, tanto por separado como combinadas entre sí, procedemos a evaluar los resultados derivados del análisis.

1. En primer lugar, no existe una diferencia significativa entre el número de homicidios y el de asesinatos, sino que prácticamente los casos enjuiciados se reparten por mitades casi iguales.

Dentro de cada uno de los tipos sí que hay una distinción importante en su clasificación. Los homicidios enjuiciados en estos casos son en su mayor parte dolosos, frente a los pocos que se cometen por imprudencia. Esto es debido al alto número de conformidades en los homicidios imprudentes, aparte de que muchos de ellos no llegan a la fase de juicio oral, de ahí que exista esa diferencia cuando en la realidad es mayor la cantidad de homicidios culposos que dolosos. 
En cuanto a las características que califican el asesinato, es claramente mayoritaria la alevosía frente a los otros supuestos de precio, recompensa o promesa; ensañamiento; o para facilitar otro o evitar que se descubra. Es más, de los 235 casos estudiados, en ninguno se dio en exclusiva la circunstancia de precio ni la de cometer el delito para facilitar otro.

2. El veredicto del jurado tampoco hace distinción entre los homicidios dolosos y los imprudentes. Sí hay una variación respecto a las sentencias de conformidad, que se dan más en los casos de homicidios dolosos que han llegado al juicio por jurado. Es posible que este hecho provoque que, en proporción, se hayan recurrido más los homicidios imprudentes.

3. Los veredictos emitidos en estos tipos delictivos son, en su mayoría, de culpabilidad y se han dictado más sentencias condenatorias en casos de asesinato que de homicidio.

La conformidad es más frecuente en los homicidios que en los asesinatos $\mathrm{y}$, en ambos casos, el número de este tipo de resoluciones supera incluso el de veredictos de inculpabilidad.

Las sentencias que se recurren al TSJ son algo más de la mitad de los casos y en mayor número en los asesinatos.

4. La diferencia entre hombres y mujeres existe en el número de delitos cometidos, muchos más por parte de los varones, pero a la hora de emitir el veredicto no se producen diferencias y el jurado no tiende a ser más benévolo con ninguno de ellos. En los dos supuestos la mayoría son declarados culpables. 
Donde sí se aprecia una desigualdad es en el tipo de delito cometido; así, el porcentaje de los hombres acusados es mayor en el caso de los homicidios, mientras que las mujeres, en proporción a los ilícitos llevados a cabo por ellas, cometen más asesinatos. Esta situación puede explicarse debido a que las féminas actúen más con la circunstancia de la alevosía que califica el asesinato, motivado por la diferencia de fuerza física que puede llevar a los hombres a cometer homicidios.

Los hombres han recurrido las resoluciones de las Audiencias algo más que las mujeres, aunque puede deberse a que ellas han aceptado más sentencias de conformidad, extremo en el que sí apreciamos una diferencia mayor.

5. Por provincias, donde más casos han tenido lugar ha sido en Burgos y León, en el mismo porcentaje, y, tras ellas, Valladolid. La explicación a las dos primeras puede fundamentarse en el número de delitos producidos en el ámbito rural, ya que estamos hablando de todo el territorio provincial. La que menos ha tenido ha sido Soria, con tan solo cinco juicios.

En cuanto a la separación de los dos delitos en cada provincia, en algunas se ha producido aproximadamente el mismo número de homicidios que de asesinatos, mientras que en otras sí existe diferencia, destacando Salamanca, en la que se han juzgado más del doble de homicidios que de asesinatos, y en el caso contrario, la provincia que más asesinatos ha juzgado, comparándolos con el número de homicidios, es Valladolid.

6. Ya hemos visto que los veredictos son, en un elevado porcentaje, de culpabilidad. Otra de las cuestiones que planteábamos al principio de esta tesis es saber si, de no haber sido juzgados por el jurado, el resultado 
hubiera sido el mismo o no. Esto solamente lo podemos comprobar a través de los recursos.

Por una parte, el número de sentencias de conformidad, en las que el acusado acepta la condena impuesta, no nos presenta un problema a esta cuestión, al no actuar el jurado. Por otra, el número de resoluciones que no se recurren que representa casi la mitad, también produce que el resultado no se modifique.

De modo que, por último, debemos centrarnos en las sentencias recurridas en apelación y la decisión del TSJCyL, en lo concerniente a la culpabilidad y a la no culpabilidad de los condenados y los absueltos, respectivamente. El resultado obtenido tras el examen es claro: solo un $4 \%$ de las sentencias es revocado, lo que se corresponde con 5 veredictos, o lo que es lo mismo, el $96 \%$ de las decisiones del jurado ha sido confirmado por el órgano superior, lo que, en principio, nos conduce a pensar que prácticamente en todos los casos se hubiese producido el mismo resultado.

Esta circunstancia ocurre en ambos sentidos, es decir, tanto para la culpabilidad como para la no culpabilidad. Por tanto, vemos que el jurado también emite veredictos de no culpable y que son ratificados por los magistrados.

Si nos centramos en el ámbito territorial, las resoluciones de 5 de las 9 Audiencias Provinciales han sido confirmadas en su totalidad. León destaca en la no confirmación, ya que de los 5 veredictos anulados, 2 pertenecen a esa provincia.

7. Aún queda comprobar cuál es el fallo del Tribunal Supremo, al que ya se recurren menos resoluciones, por lo que muchas de las ratificaciones del TSJ hacen que las partes desistan en su intención de 
continuar recurriendo. Esto nos lo corrobora el hecho de que ninguna de las sentencias revocadas por el TSJCyL es recurrida ante el Supremo.

Si comentábamos que en apelación habían recurrido más los hombres que las mujeres, al llegar al Supremo, la diferencia se incrementa mucho más y ya son solo 8 las mujeres que recurren, cuyas resoluciones además son todas confirmadas.

El resultado tras examinar las sentencias que resuelven los recursos de casación (bastantes más de asesinato que de homicidio) nos demuestra que, al igual que sucede en el primer recurso, se confirman en un porcentaje muy superior $\left(93^{\prime}, 8 \%\right)$ a las no confirmadas $\left(6{ }^{\prime} 3 \%\right)$, que únicamente son 3 veredictos, por lo que una vez más, se verifica que los veredictos del jurado no han sido erróneos y que si, al menos esos en casos, se hubiese seguido un procedimiento ordinario, las condenas y absoluciones se hubieran resuelto en el mismo sentido.

8. Esta conclusión no solo nos acredita que los jurados no se equivocan en sus apreciaciones, sino que, nos aclara la segunda cuestión que planteábamos al comenzar esta investigación: ¿son los jurados más severos en sus veredictos que los jueces en sus condenas? Rotundamente no, en primer lugar porque casi todos los veredictos se han confirmado y, en segundo, porque de los 3 anulados (todos afectan a hombres), 2 de ellos eran de inculpabilidad (en homicidios), el Supremo casó la sentencia y ordenó la repetición del juicio.

Es decir, que la creencia de que el jurado es más implacable en sus veredictos que los jueces en sus condenas no es cierta, al menos en los delitos más graves, homicidios y asesinatos, puesto que de los 235 veredictos iniciales, solo 1 (asesinato) fue de culpabilidad en principio y revocado hacia la no culpabilidad por el Supremo en última instancia. 


\subsection{Estadísticas del Consejo General del Poder Judicial (CGPJ).}

Por último, cabe plantearse si estos resultados en el ámbito de Castilla y León son extrapolables al resto del territorio nacional. En principio, no tienen por qué darse los mismos resultados en todas las Comunidades Autónomas. Para poder realizar una aproximación, hemos consultado las últimas estadísticas oficiales publicadas por el $\mathrm{CGPJ}^{556}$, de las que extraemos las siguientes conclusiones:

- Hubo 266 enjuiciados en el año 2016, de los que 245 fueron condenados y 21 absueltos.

- Dichos enjuiciados se corresponden con un total de 209 sentencias, 193 condenatorias y 16 absolutorias. Solo 9 de esas sentencias se produjeron en el ámbito territorial de Castilla y León.

- De los 266 procesados, en 81 casos se les juzgaba por el delito de asesinato, repartidos de la siguiente forma:

- 73 exclusivamente por asesinato,

- 8 por asesinato junto con otros delitos (1 allanamiento de morada, 1 delito de amenazas, 1 homicidio en grado de tentativa y 5 omisiones del deber de socorro).

- 52 son juzgados por homicidio:

○ 48 exclusivamente por homicidio,

- 4 homicidios con otros delitos conexos (2 allanamientos de morada y dos omisiones del deber de socorro).

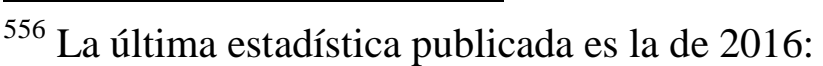

http://www.poderjudicial.es/cgpj/es/Temas/Estadistica-Judicial/Estadistica-portemas/Datos-penales--civiles-y-laborales/Delitos-y-condenas/Tribunal-del-Jurado/ 


\begin{tabular}{|l|r|r|r|r|}
\hline \multicolumn{1}{|c|}{ Delitos } & \multicolumn{2}{c|}{ Condenados } & \multicolumn{2}{c|}{ Absueltos } \\
\hline & Hombres & \multicolumn{1}{c|}{ Mujeres } & Hombres & Mujeres \\
\hline Asesinato & 62 & 6 & 4 & 1 \\
\hline Asesinato/Allanamiento de morada & & 1 & & \\
\hline Asesinato/Amenazas & 1 & & & \\
\hline Asesinato/homicidio grado tentativa & 1 & & & \\
\hline Asesinato/Omisión del deber de socorro & 3 & 2 & & \\
\hline Homicidio & 33 & 6 & 4 & 2 \\
\hline Homicidio/Allanamiento de morada & 2 & & & \\
\hline Homicidio/omisión deber de socorro & 1 & 1 & & \\
\hline Homicidio & 3 & & & \\
\hline Total delitos contra la vida (133) & $\mathbf{1 0 6}$ & $\mathbf{1 6}$ & $\mathbf{8}$ & $\mathbf{3}$ \\
\hline Total delitos enjuiciados por jurado (266) & $\mathbf{2 0 6}$ & $\mathbf{3 9}$ & $\mathbf{1 3}$ & $\mathbf{8}$ \\
\hline
\end{tabular}

Tabla 06. Enjuiciados por delito.

Fuente: informe jurado 2016 del Consejo General del Poder Judicial.

Esta tabla representa los delitos de homicidio y asesinato juzgados por el jurado en 2016, con el número de condenados y de absueltos, y separados por hombres y mujeres. La última línea del total indica el número de todos los delitos enjuiciados y no solo los que son contra la vida, lo que nos indica que los homicidios y asesinatos son justo la mitad de los delitos juzgados por el jurado durante ese año, es decir, 133 de los 266.

También aquí vemos que la mayoría son declarados culpables, ya que hay 122 condenados por 11 absueltos, eso en los delitos contra la vida. Si comparamos estas cifras con las de la totalidad de los delitos enjuiciados (245 condenas y 21 absoluciones), una vez más se demuestra que los jurados no son especialmente severos a la hora de condenar los delitos contra la vida respecto a otros tipos delictivos, ya que la correspondencia es prácticamente la misma. 
Por lo tanto, como hemos comentado, por una parte, no se pueden extrapolar completamente los resultados obtenidos en Castilla y León debido a los siguientes factores:

- Solo disponemos de la muestra en toda España correspondiente a 2016, lo que hace que sean pocos casos analizados.

- Únicamente 9 de las 206 sentencias han sido dictadas en Castilla y León y desconocemos sobre qué delitos han sido. Esto puede influir en que quizás haya otros ilícitos penales distintos a los delitos contra la vida en los que la tasa de absolución sea mayor.

- Esta estadística del CGPJ se refiere a las sentencias en primera instancia, no sabemos cuántas se recurren ni en qué sentido resuelven los órganos superiores.

Sin embargo, por otra parte y, con las reservas expuestas, advertimos que la tendencia general sí es la misma que la obtenida tras analizar los resultados obtenidos en Castilla y León, es decir, una mayoría de veredictos de culpabilidad y sin distinción entre sexos, más allá de la diferencia del número de delitos que cometen los hombres al compararlo con la delincuencia femenina, lo que nos puede llevar a deducir que en el resto del territorio el acierto del jurado sea también mayoritario. 


\section{CONCLUSIONES}

1. La institución del jurado ha sido cuestionada desde sus inicios y aún hoy continúa siendo fuente de debates entre partidarios y detractores. Su base constitucional le confiere un carácter de participación democrática en la Administración de Justicia, algo que ya ocurría en la antigüedad.

2. Los delitos contra la vida históricamente han sido figuras penadas con severidad en todos los ordenamientos jurídicos, lo mismo que en la actualidad, tanto en España como en el Derecho comparado. Sin embargo, a pesar de su gravedad, debido a la escasa complejidad que presenta lo estrictamente relativo al hecho de estos ilícitos penales, justifica que sean competencia del tribunal del jurado en nuestro país, algo con lo que estamos de acuerdo.

3. Siguiendo el sistema anglosajón, dentro de los distintos tipos de jurado, la clave para el enjuiciamiento en España es la separación entre el hecho y el Derecho, lo que motiva la intervención de ciudadanos legos para ocuparse exclusivamente de lo concerniente a los hechos mientras que son los miembros de la carrera judicial quienes se encargan de las cuestiones jurídicas, en particular, imponer las penas en caso de sentencia condenatoria. Dicha separación es, a nuestro juicio, lo más defendible del jurado, ya que los ciudadanos no van a entrar sobre aspectos jurídicos que no comprendan aunque quizás una evolución hacia el modelo escabinado podría ser positivo puesto que se produce la participación conjunta de legos y profesionales y eso podría causar un mayor 
apoyo tanto social como por parte de las instancias judiciales y políticas.

4. En las sentencias analizadas, referentes a los delitos contra la vida, hemos observado que la mayoría de los veredictos han sido de culpabilidad, 168 de los 235 iniciales, lo que supone un $71^{\prime} 5 \%$ del total.

5. Hemos apreciado numerosas sentencias de conformidad, tanto en el homicidio como en el asesinato, por lo que el número de recursos a medida que se acude a un tribunal superior, se va reduciendo. Las apelaciones han sido de poco más de la mitad de las resoluciones en primera instancia. El Tribunal Superior de Justicia de Castilla y León ha confirmado las sentencias de las Audiencias Provinciales en un 96\% de los casos, 120 de 125 veredictos, lo que nos lleva a concluir que, en un primer momento, de haber sido el delito juzgado por profesionales, el resultado hubiera sido el mismo y el jurado, por lo tanto, no es más severo en sus veredictos que los jueces en sus sentencias.

6. Los recursos al órgano Supremo de nuestro sistema judicial vuelven a disminuir y se acude a la casación en un $38 \%$ de los supuestos. Finalmente, el Tribunal Supremo confirma 45 de 48 veredictos, es decir, el 93'8\%, lo que reafirma que los veredictos de los jurados son acertados y un tribunal de magistrados había procedido de la misma forma.

7. La creencia generalizada en la sociedad de que los jurados son más inflexibles es contraria a los resultados obtenidos, dado que, dentro 
del 6'3\% de veredictos no confirmados, que son solo 3 supuestos, en 2 de ellos lo que se revoca es la no culpabilidad, por lo que concluimos que el jurado no es más severo que los expertos, ya que de los 235 veredictos iniciales, únicamente 1 acusado fue declarado culpable en primera instancia y con posterioridad no culpable por los órganos superiores.

8. No observamos diferencias entre los dos delitos. Tanto la culpabilidad como no la culpabilidad se dan en porcentajes parecidos en el homicidio y el asesinato.

9. Tampoco existe diferencia entre si el acusado es un hombre o una mujer, los jurados no son más benevolentes con unos que con otros. La única distinción es en el número de delitos contra la vida que cometen los hombres, que es bastante mayor que el cometen las mujeres pero eso no afecta en absoluto al veredicto.

10. Que en el sistema puro el jurado se limite a juzgar los hechos es una ventaja que no presentan los otros modelos, sin embargo, la particularidad de la legislación española que obliga a motivar el veredicto, puede dificultar su labor, a pesar de estar dirigidos por un experto. Implantar el modelo escabinado, como sucede en gran parte de los países de nuestro entorno, supliría esa carencia de conocimientos aunque tendría la desventaja de que los ciudadanos sí que intervienen en los aspectos jurídicos. Tal vez una mezcla de ambos sea lo idóneo para que la sociedad se conciencie más con el jurado. 
11. Puede que estos resultados se produzcan en este sentido al ser el tipo delictivo estudiado uno de los más graves y probablemente más claros a la hora de juzgar los hechos. Sin embargo, el breve análisis de las estadísticas del Consejo General del Poder Judicial, nos inclina a pensar que en el resto de delitos, aunque los porcentajes no sean tan altos como en los homicidios y los asesinatos, la tendencia de los jurados también es correcta. 


\section{JURISPRUDENCIA}

\section{SENTENCIAS DEL TRIBUNAL SUPREMO}

STS 1443/1999 - ECLI:ES:TS:1999:1443

STS 1760/1999 - ECLI:ES:TS:1999:1760

STS 3028/1999 - ECLI:ES:TS:1999:3028

STS 6214/1999 - ECLI:ES:TS:1999:6214

STS 1311/2000 - ECLI:ES:TS:2000:1311

STS 3414/2000 - ECLI:ES:TS:2000:3414

STS 6237/2000 - ECLI:ES:TS:2000:6237

STS 9719/2000 - ECLI:ES:TS:2000:9719

STS 4636/2001 - ECLI:ES:TS:2001:4636

STS 7925/2001 - ECLI:ES:TS:2001:7925

STS 3013/2002 - ECLI:ES:TS:2002:3013

STS 5829/2002 - ECLI:ES:TS:2002:5829

STS 3753/2003 - ECLI:ES:TS:2003:3753

STS 6884/2003 - ECLI:ES:TS:2003:6884

STS 8432/2003 - ECLI:ES:TS:2003:8432

STS 3741/2004 - ECLI:ES:TS:2004:3741

STS 6279/2004 - ECLI:ES:TS:2004:6279

STS 6474/2004 - ECLI:ES:TS:2004:6474

STS 2670/2005 - ECLI:ES:TS:2005:2670

STS 6892/2005 - ECLI:ES:TS:2005:6892

STS 7739/2005 - ECLI:ES:TS:2005:7739

STS 3009/2006 - ECLI:ES:TS:2006:3009 
STS 410/2007 - ECLI:ES:TS:2007:410

STS 3092/2009 - ECLI:ES:TS:2009:3092

STS 753/2010 - ECLI:ES:TS:2010:753

STS 760/2010 - ECLI:ES:TS:2010:760

STS 3684/2010 - ECLI:ES:TS:2010:3684

STS 9143/2011 - ECLI:ES:TS:2011:9143

STS 1954/2012 - ECLI:ES:TS:2012:1954

STS 6335/2012 - ECLI:ES:TS:2012:6335

STS 7654/2012 - ECLI:ES:TS:2012:7654

STS 5100/2013 - ECLI:ES:TS:2013:5100

STS 5316/2013 - ECLI:ES:TS:2013:5316

STS 1526/2015 - ECLI:ES:TS:2015:1526

STS 2461/2015 - ECLI:ES:TS:2015:2461

STS 5074/2015 - ECLI:ES:TS:2015:5074

STS 1490/2016 - ECLI:ES:TS:2016:1490

STS 2940/2016 - ECLI:ES:TS:2016:2940

STS 5521/2016 - ECLI:ES:TS:2016:5521

SENTENCIAS DEL TRIBUNAL SUPERIOR DE JUSTICIA DE CASTILLA Y LEÓN

STSJ CL 1348/1997 - ECLI:ES:TSJCL:1997:1348

STSJ CL 387/1998 - ECLI:ES:TSJCL:1998:387

STSJ CL 1021/1998 - ECLI:ES:TSJCL:1998:1021

STSJ CL 1464/1998 - ECLI:ES:TSJCL:1998:1464

STSJ CL 1599/1998 - ECLI:ES:TSJCL:1998:1599 
STSJ CL 2646/1998 - ECLI:ES:TSJCL:1998:2646

STSJ CL 3313/1998 - ECLI:ES:TSJCL:1998:3313

STSJ CL 3691/1998 - ECLI:ES:TSJCL:1998:3691

STSJ CL 3718/1998 - ECLI:ES:TSJCL:1998:3718

STSJ CL 4607/1998 - ECLI:ES:TSJCL:1998:4607

STSJ CL 499/1999 - ECLI:ES:TSJCL:1999:499

STSJ CL 837/1999 - ECLI:ES:TSJCL:1999:837

STSJ CL 2418/1999 - ECLI:ES:TSJCL:1999:2418

STSJ CL 3344/1999 - ECLI:ES:TSJCL:1999:3344

STSJ CL 3944/1999 - ECLI:ES:TSJCL:1999:3944

STSJ CL 3977/1999 - ECLI:ES:TSJCL:1999:3977

STSJ CL 4279/1999 - ECLI:ES:TSJCL:1999:4279

STSJ CL 5304/1999 - ECLI:ES:TSJCL:1999:5304

STSJ CL 3/2000 - ECLI:ES:TSJCL:2000:3

STSJ CL 1719/2000 - ECLI:ES:TSJCL:2000:1719

STSJ CL 3326/2000 - ECLI:ES:TSJCL:2000:3326

STSJ CL 3621/2000 - ECLI:ES:TSJCL:2000:3621

STSJ CL 5892/2000 - ECLI:ES:TSJCL:2000:5892

STSJ CL 6242/2000 - ECLI:ES:TSJCL:2000:6242

STSJ CL 293/2001 - ECLI:ES:TSJCL:2001:293

STSJ CL 1358/2001 - ECLI:ES:TSJCL:2001:1358

STSJ CL 3474/2001 - ECLI:ES:TSJCL:2001:3474

STSJ CL 3685/2001 - ECLI:ES:TSJCL:2001:3685

STSJ CL 4117/2001 - ECLI:ES:TSJCL:2001:4117 
STSJ CL 5399/2001 - ECLI:ES:TSJCL:2001:5399

STSJ CL 4602/2002 - ECLI:ES:TSJCL:2002:4602

STSJ CL 4895/2002 - ECLI:ES:TSJCL:2002:4895

STSJ CL 5805/2002 - ECLI:ES:TSJCL:2002:5805

STSJ CL 1176/2003 - ECLI:ES:TSJCL:2003:1176

STSJ CL 598/2004 - ECLI:ES:TSJCL:2004:598

STSJ CL 721/2004 - ECLI:ES:TSJCL:2004:721

STSJ CL 5457/2004 - ECLI:ES:TSJCL:2004:5457

STSJ CL 521/2005 - ECLI:ES:TSJCL:2005:521

STSJ CL 2163/2005 - ECLI:ES:TSJCL:2005:2163

STSJ CL 2907/2005 - ECLI:ES:TSJCL:2005:2907

STSJ CL 4468/2005 - ECLI:ES:TSJCL:2005:4468

STSJ CL 5792/2005 - ECLI:ES:TSJCL:2005:5792

STSJ CL 76/2006 - ECLI:ES:TSJCL:2006:76

STSJ CL 6346/2006 - ECLI:ES:TSJCL:2006:6346

STSJ CL 6466/2006 - ECLI:ES:TSJCL:2006:6466

STSJ CL 6467/2006 - ECLI:ES:TSJCL:2006:6467

STSJ CL 6252/2006 - ECLI:ES:TSJCL:2006:6252

STSJ CL 6253/2006 - ECLI:ES:TSJCL:2006:6253

STSJ CL 6254/2006 - ECLI:ES:TSJCL:2006:6254

STSJ CL 6256/2006 - ECLI:ES:TSJCL:2006:6256

STSJ CL 6275/2006 - ECLI:ES:TSJCL:2006:6275

STSJ CL 320/2007 - ECLI:ES:TSJCL:2007:320

STSJ CL 3357/2007 - ECLI:ES:TSJCL:2007:335 
STSJ CL 7074/2007 - ECLI:ES:TSJCL:2007:7074

SAP CL 7/2008 - ECLI:ES:TSJCL:2008:7

STSJ CL 2356/2008 - ECLI:ES:TSJCL:2008:2356

STSJ CL 4932/2008 - ECLI:ES:TSJCL:2008:4932

STSJ CL 6990/2008 - ECLI:ES:TSJCL:2008:6990

STSJ CL 786/2009 - ECLI:ES:TSJCL:2009:786

STSJ CL 3806/2009 - ECLI:ES:TSJCL:2009:3806

STSJ CL 4692/2009 - ECLI:ES:TSJCL:2009:4692

STSJ CL 6912/2009 - ECLI:ES:TSJCL:2009:6912

STSJ CL 371/2010 - ECLI:ES:TSJCL:2010:371

STSJ CL 3201/2010 - ECLI:ES:TSJCL:2010:3201

STSJ CL 4859/2010 - ECLI:ES:TSJCL:2010:4859

STSJ CL 1222/2011 - ECLI:ES:TSJCL:2011:1222

STSJ CL 683/2011 - ECLI:ES:TSJCL:2011:683

STSJ CL 1220/2011 - ECLI:ES:TSJCL:2011:1220

STSJ CL 1221/2011 - ECLI:ES:TSJCL:2011:1221

STSJ CL 1935/2011 - ECLI:ES:TSJCL:2011:1935

STSJ CL 2721/2011 - ECLI:ES:TSJCL:2011:2721

STSJ CL 4566/2011 - ECLI:ES:TSJCL:2011:4566

STSJ CL 6487/2011 - ECLI:ES:TSJCL:2011:6487

STSJ CL 1752/2012 - ECLI:ES:TSJCL:2012:1752

STSJ CL 2174/2012 - ECLI:ES:TSJCL:2012:2174

STSJ CL 3682/2012 - ECLI:ES:TSJCL:2012:3682

STSJ CL 5612/2012 - ECLI:ES:TSJCL:2012:5612 
STSJ CL 5612/2012 - ECLI:ES:TSJCL:2012:5612

STSJ CL 260/2013 - ECLI:ES:TSJCL:2013:260

STSJ CL 91/2013 - ECLI:ES:TSJCL:2013:91

STSJ CL 2671/2013 - ECLI:ES:TSJCL:2013:2671

STSJ CL 1391/2014 - ECLI:ES:TSJCL:2014:1391

STSJ CL 2423/2014 - ECLI:ES:TSJCL:2014:2423

STSJ CL 3973/2014 - ECLI:ES:TSJCL:2014:3973

STSJ CL 6194/2014 - ECLI:ES:TSJCL:2014:6194

STSJ CL 410/2015 - ECLI:ES:TSJCL:2015:410

STSJ CL 1752/2015 - ECLI:ES:TSJCL:2015:1752

STSJ CL 3423/2015 - ECLI:ES:TSJCL:2015:3423

STSJ CL 3646/2015 - ECLI:ES:TSJCL:2015:3646

STSJ CL 4643/2015 - ECLI:ES:TSJCL:2015:4643

STSJ CL 5047/2015 - ECLI:ES:TSJCL:2015:5047

STSJ CL 1438/2016 - ECLI:ES:TSJCL:2016:1438

STSJ CL 1906/2016 - ECLI:ES:TSJCL:2016:1906

STSJ CL 2366/2017 - ECLI:ES:TSJCL:2017:2366

STSJ CL 3118/2017 - ECLI:ES:TSJCL:2017:3118

STSJ CL 3396/2017 - ECLI:ES:TSJCL:2017:3396

SENTENCIAS DE LA AUDIENCIA PROVINCIAL DE ÁVILA

SAP AV 127/1999 - ECLI:ES:APAV:1999:127

SAP AV 398/1999 - ECLI:ES:APAV:1999:398

SAP AV 16/2001 - ECLI:ES:APAV:2001:16 
SAP AV 204/2001 - ECLI:ES:APAV:2001:204

SAP AV 469/2001 - ECLI:ES:APAV:2001:469

SAP AV 180/2002 - ECLI:ES:APAV:2002:180

SAP AV 35/2009 - ECLI:ES:APAV:2009:35

SAP AV 65/2009 - ECLI:ES:APAV:2009:65

SAP AV 492/2010 - ECLI:ES:APAV:2010:492

SAP AV 440/2012 - ECLI:ES:APAV:2012:440

SAP AV 333/2013 - ECLI:ES:APAV:2013:333

SAP AV 560/2016 - ECLI:ES:APAV:2016:560

SENTENCIAS DE LA AUDIENCIA PROVINCIAL DE BURGOS

SAP BU 72/1997 - ECLI:ES:APBU:1997:72

SAP BU 575/1998 - ECLI:ES:APBU:1998:575

SAP BU 1118/1999 - ECLI:ES:APBU:1999:1118

SAP BU 733/1999 - ECLI:ES:APBU:1999:733

SAP BU 491/2000 - ECLI:ES:APBU:2000:491

SAP BU 604/2000 - ECLI:ES:APBU:2000:604

SAP BU 1099/2000 - ECLI:ES:APBU:2000:1099

SAP BU 1157/2000 - ECLI:ES:APBU:2000:1157

SAP BU 256/2001 - ECLI:ES:APBU:2001:256

SAP BU 771/2002 - ECLI:ES:APBU:2002:771

SAP BU 1245/2002 - ECLI:ES:APBU:2002:1245

SAP BU 104/2003 - ECLI:ES:APBU:2003:104

SAP BU 1112/2003 - ECLI:ES:APBU:2003:1112 
SAP BU 752/2004 - ECLI:ES:APBU:2004:752

SAP BU 1071/2004 - ECLI:ES:APBU:2004:1071

SAP BU 1009/2005 - ECLI:ES:APBU:2005:1009

SAP BU 120/2006 - ECLI:ES:APBU:2006:120

SAP BU 151/2006 - ECLI:ES:APBU:2006:151

SAP BU 1172/2007 - ECLI:ES:APBU:2007:1172

SAP BU 1171/2007 - ECLI:ES:APBU:2007:1171

SAP BU 1174/2007 - ECLI:ES:APBU:2007:1174

SAP BU 831/2009 - ECLI:ES:APBU:2009:831

SAP BU 1238/2009 - ECLI:ES:APBU:2009:1238

SAP BU 1208/2010 - ECLI:ES:APBU:2010:1208

SAP BU 1292/2010 - ECLI:ES:APBU:2010:1292

SAP BU 1337/2010 - ECLI:ES:APBU:2010:1337

SAP BU 1496/2010 - ECLI:ES:APBU:2010:1496

SAP BU 809/2011 - ECLI:ES:APBU:2011:809

SAP BU 916/2011 - ECLI:ES:APBU:2011:916

SAP BU 1153/2011 - ECLI:ES:APBU:2011:1153

SAP BU 89/2012 - ECLI:ES:APBU:2012:89

SAP BU 556/2012 - ECLI:ES:APBU:2012:556

SAP BU 851/2012 - ECLI:ES:APBU:2012:851

SAP BU 919/2012 - ECLI:ES:APBU:2012:919

SAP BU 1028/2012 - ECLI:ES:APBU:2012:1028

SAP BU 1225/2012 - ECLI:ES:APBU:2012:1225

SAP BU 42/2014 - ECLI:ES:APBU:2014:42 
SAP BU 631/2014 - ECLI:ES:APBU:2014:631

STSJ CL 820/2017 - ECLI:ES:TSJCL:2017:820

\section{SENTENCIAS DE LA AUDIENCIA PROVINCIAL DE LEÓN}

SAP LE 687/1998 - ECLI:ES:APLE:1998:687

SAP LE 1261/1998 - ECLI:ES:APLE:1998:1261

SAP LE 1353/1998 - ECLI:ES:APLE:1998:1353

SAP LE 374/1999 - ECLI:ES:APLE:1999:374

SAP LE 859/1999 - ECLI:ES:APLE:1999:859

SAP LE 935/1999 - ECLI:ES:APLE:1999:935

SAP LE 170/2000 - ECLI:ES:APLE:2000:170

SAP LE 1019/2000 - ECLI:ES:APLE:2000:1019

SAP LE 1093/2000 - ECLI:ES:APLE:2000:1093

SAP LE 1565/2000 - ECLI:ES:APLE:2000:1565

SAP LE 1968/2000 - ECLI:ES:APLE:2000:1968

SAP LE 2368/2000 - ECLI:ES:APLE:2000:2368

SAP LE 1892/2001 - ECLI:ES:APLE:2001:1892

SAP LE 2066/2001 - ECLI:ES:APLE:2001:2066

SAP LE 298/2002 - ECLI:ES:APLE:2002:298

SAP LE 2089/2002 - ECLI:ES:APLE:2002:2089

SAP LE 117/2003 - ECLI:ES:APLE:2003:117

SAP LE 460/2003 - ECLI:ES:APLE:2003:460

SAP LE 1558/2003 - ECLI:ES:APLE:2003:1558

SAP LE 1098/2005 - ECLI:ES:APLE:2005:1098 
SAP LE 1388/2005 - ECLI:ES:APLE:2005:1388

SAP LE 1355/2005 - ECLI:ES:APLE:2005:1355

SAP LE 238/2006 - ECLI:ES:APLE:2006:238

SAP LE 1339/2007 - ECLI:ES:APLE:2007:1339

SAP LE 786/2010 - ECLI:ES:APLE:2010:786

SAP LE 233/2011 - ECLI:ES:APLE:2011:233

SAP LE 901/2013 - ECLI:ES:APLE:2013:901

SAP LE 227/2014 - ECLI:ES:APLE:2014:227

SAP LE 370/2014 - ECLI:ES:APLE:2014:370

SAP LE 453/2014 - ECLI:ES:APLE:2014:453

SAP LE 52/2015 - ECLI:ES:APLE:2015:52

SAP LE 25/2015 - ECLI:ES:APLE:2015:25

SAP LE 636/2015 - ECLI:ES:APLE:2015:636

SAP LE 670/2015 - ECLI:ES:APLE:2015:670

SAP LE 93/2016 - ECLI:ES:APLE:2016:93

SAP LE 564/2016 - ECLI:ES:APLE:2016:564

SAP LE 62/2017 - ECLI:ES:APLE:2017:62

SAP LE 373/2017 - ECLI:ES:APLE:2017:373

SAP LE 1007/2017 - ECLI:ES:APLE:2017:1007

SAP LE 1068/2017 - ECLI:ES:APLE:2017:1068

SENTENCIAS DE LA AUDIENCIA PROVINCIAL DE PALENCIA

SAP P 1/1996 - ECLI:ES:APP:1996:1

SAP P 198/2001 - ECLI:ES:APP:2001:198 
SAP P 228/2003 - ECLI:ES:APP:2003:228

SAP P 667/2006 - ECLI:ES:APP:2006:667

SAP P 472/2008 - ECLI:ES:APP:2008:472

SAP P 559/2010 - ECLI:ES:APP:2010:559

SAP P 560/2012 - ECLI:ES:APP:2012:560

SAP P 142/2015 - ECLI:ES:APP:2015:142

SAP P 78/2016 - ECLI:ES:APP:2016:78

SENTENCIAS DE LA AUDIENCIA PROVINCIAL DE SALAMANCA

SAP SA 535/1999 - ECLI:ES:APSA:1999:535

SAP SA 557/1999 - ECLI:ES:APSA:1999:557

SAP SA 566/1999 - ECLI:ES:APSA:1999:566

SAP SA 398/2000 - ECLI:ES:APSA:2000:398

SAP SA 805/2001 - ECLI:ES:APSA:2001:805

SAP SA 200/2003 - ECLI:ES:APSA:2003:200

SAP SA 373/2004 - ECLI:ES:APSA:2004:373

SAP SA 382/2004 - ECLI:ES:APSA:2004:382

SAP SA 760/2004 - ECLI:ES:APSA:2004:760

SAP SA 382/2005 - ECLI:ES:APSA:2005:382

SAP SA 27/2009 - ECLI:ES:APSA:2009:27

SAP SA 669/2009 - ECLI:ES:APSA:2009:669

SAP SA 622/2010 - ECLI:ES:APSA:2010:622

SAP SA 175/2011 - ECLI:ES:APSA:2011:175

SAP SA 364/2011 - ECLI:ES:APSA:2011:364 
SAP SA 412/2017 - ECLI:ES:APSA:2017:412

SENTENCIAS DE LA AUDIENCIA PROVINCIAL DE SEGOVIA

SAP SG 442/2000 - ECLI:ES:APSG:2000:442

SAP SG 244/2002 - ECLI:ES:APSG:2002:244

SAP SG 261/2007 - ECLI:ES:APSG:2007:261

SAP SG 255/2008 - ECLI:ES:APSG:2008:255

SAP SG 397/2010 - ECLI:ES:APSG:2010:397

SAP SG 175/2011 - ECLI:ES:APSG:2011:175

SAP SG 28/2013 - ECLI:ES:APSG:2013:28

SAP SG 38/2013 - ECLI:ES:APSG:2013:38

SAP SG 209/2013 - ECLI:ES:APSG:2013:209

SAP SG 316/2013 - ECLI:ES:APSG:2013:316

SENTENCIAS DE LA AUDIENCIA PROVINCIAL DE SORIA

SAP SO 305/1998 - ECLI:ES:APSO:1998:305

SAP SO 31/2000 - ECLI:ES:APSO:2000:31

SAP SO 233/2012 - ECLI:ES:APSO:2012:233

SAP SO 58/2014 - ECLI:ES:APSO:2014:58

SAP SO 205/2017 - ECLI:ES:APSO:2017:205

SENTENCIAS DE LA AUDIENCIA PROVINCIAL DE VALLADOLID

SAP VA 881/1998 - ECLI:ES:APVA:1998:881

SAP VA 907/1999 - ECLI:ES:APVA:1999:907 
SAP VA 1090/1999 - ECLI:ES:APVA:1999:1090

SAP VA 1418/1999 - ECLI:ES:APVA:1999:1418

SAP VA 263/2000 - ECLI:ES:APVA:2000:263

SAP VA 499/2001 - ECLI:ES:APVA:2001:499

SAP VA 537/2003 - ECLI:ES:APVA:2003:537

SAP VA 1011/2003 - ECLI:ES:APVA:2003:1011

SAP VA 1545/2003 - ECLI:ES:APVA:2003:1545

SAP VA 347/2005 - ECLI:ES:APVA:2005:347

SAP VA 1667/2005 - ECLI:ES:APVA:2005:1667

SAP VA 109/2008 - ECLI:ES:APVA:2008:109

SAP VA 1194/2008 - ECLI:ES:APVA:2008:1194

SAP VA 1480/2009 - ECLI:ES:APVA:2009:1480

SAP VA 1476/2009 - ECLI:ES:APVA:2009:1476

SAP VA 1239/2009 - ECLI:ES:APVA:2009:1239

SAP VA 669/2010 - ECLI:ES:APVA:2010:669

SAP VA 1160/2010 - ECLI:ES:APVA:2010:1160

SAP VA 1563/2010 - ECLI:ES:APVA:2010:1563

SAP VA 246/2011 - ECLI:ES:APVA:2011:246

SAP VA 1111/2012 - ECLI:ES:APVA:2012:1111

SAP VA 1256/2013 - ECLI:ES:APVA:2013:1256

SAP VA 544/2014 - ECLI:ES:APVA:2014:544

SAP VA 1021/2014 - ECLI:ES:APVA:2014:1021

SAP VA 480/2015 - ECLI:ES:APVA:2015:480

SAP VA 461/2015 - ECLI:ES:APVA:2015:461 
SAP VA 686/2015 - ECLI:ES:APVA:2015:686

SAP VA 1055/2015 - ECLI:ES:APVA:2015:1055

SAP VA 50/2017 - ECLI:ES:APVA:2017:50

SENTENCIAS DE LA AUDIENCIA PROVINCIAL DE ZAMORA

SAP ZA 2/1997 - ECLI:ES:APZA:1997:2

SAP ZA 163/1998 - ECLI:ES:APZA:1998:163

SAP ZA 554/1998 - ECLI:ES:APZA:1998:554

SAP ZA 373/2002 - ECLI:ES:APZA:2002:373

SAP ZA 483/2005 - ECLI:ES:APZA:2005:483

SAP ZA 406/2010 - ECLI:ES:APZA:2010:406

SAP ZA 540/2011 - ECLI:ES:APZA:2011:540

SAP ZA 164/2013 - ECLI:ES:APZA:2013:164

SAP ZA 69/2014 - ECLI:ES:APZA:2014:69

SAP ZA 417/2014 - ECLI:ES:APZA:2014:417

SAP ZA 455/2015 - ECLI:ES:APZA:2015:455

\section{OTRAS SENTENCIAS CONSULTADAS:}

- STS 755/2000 - ECLI:ES:TS:2000:755

- STS 1329/2001 - ECLI:ES:TS:2001:1329

- STS 2632/2002 - ECLI:ES:TS:2002:2632

- STS 5798/2002 - ECLI:ES:TS:2002/5798

- STS 7251/2002 - ECLI:ES:TS:2002/7251

- STS 7380/2002 - ECLI:ES:TS:2002/7380 
- STS 1663/2003 - ECLI:ES:TS:2003/1663

- STS 2542/2003 - ECLI:ES:TS:2003/2542

- STS 7876/2005 - ECLI:ES:TS:2005:7876

- STS 3840/2006 - ECLI:ES:TS:2006:3840

- STS 6394/2006 - ECLI:ES:TS:2006:6394

- STS 2809/2008 - ECLI:ES:TS:2008: 2809

- STS 5947/2008 - ECLI:ES:TS:2008:5947

- STS 7260/2008 - ECLI:ES:TS:2008:7260

- STS 7816/2009 - ECLI:ES:TS:2009:7816

- STS 4567/2009 - ECLI:ES:TS:2009:4567

- STS 2563/2010 - ECLI:ES:TS:2010:2563

- STS 6348/2011 - ECLI:ES:TS:2011:6348

- STS 3486/2012 - ECLI:ES:TS:2012:3486

- STS 6546/2013 - ECLI:ES:TS:2013:6546

- STS 4924/2015 - ECLI:ES:TS:2015:4924

- STS 82/2016 - ECLI:ES:TS:2016:82

- STS 2940/2016 - ECLI:ES:TS:2016:2940

- STS 4088/2016 - ECLI:ES:TS:2016:4088

- STS 4521/2016 - ECLI:ES:TS:2016:4521

- STS 2535/2017 - ECLI:ES:TS:2017:2535

- STS 2743/2017 - ECLI:ES:TS:2017:2743

- STS 4500/2017 - ECLI:ES:TS:2017:4500

- STS 1828/2018 - ECLI:ES:TS:2018:1828

- STS 2370/2018 - ECLI:ES:TS:2018:2370 
- STS 2370/2018 - ECLI:ES:TS:2018:1784

- STS 82/2019 - ECLI:ES:TS:2019:82

- STS 1784/2019 - ECLI:ES:TS:2019:1784

- STEDH 21906/04, de 12 de febrero de 2008. 


\section{BIBLIOGRAFÍA}

- AGUdO FERnÁNDEZ, Enrique, JAÉN VALLEJO, Manuel y PERRINO PÉREZ, Ángel Luis (2016). La víctima en la justicia penal. Madrid: Dykinson.

- ALCARAZ VARÓ, Enrique (2007). El inglés jurídico: textos y documentos. Barcelona: Ariel ( $6^{\mathrm{a}} \mathrm{ed}$.).

- ALLEN, Michael J. (2001) Textbook on Criminal Law. Nueva York: Oxford University Press ( $6^{\mathrm{a}}$ ed.).

- ALONSO ÁlAMO, Mercedes (2015). El ensañamiento. Granada: Comares.

○ (2015). "La reforma del homicidio doloso y del asesinato por LO 1/2015”, en Cuadernos de política criminal, $n^{\circ} 117$, págs. $5-50$.

○ (2016). "Bases para una fundamentación material de la culpabilidad: libertad de la voluntad "en la brecha" y neurociencias", en Estudios de Derecho penal: homenaje al profesor Miguel Bajo. Madrid: Ramón Areces.

- ALONSO DE ESCAMILLA, Avelina (2017). "Delitos contra la vida humana independiente: homicidio, asesinato y suicidio", en LAMARCA PÉREZ, Carmen (coord.) (2017). Delitos. La parte especial del Derecho penal. Madrid: Dykinson ( $2^{\mathrm{a}} \mathrm{ed}$.).

- ALSCHULER, Albert W. y DEISS, Andrew G. (1994). "A Brief History of the Criminal Jury in the United States", en The University of Chicago Law Review, vol. 61, n 3, págs. 867-928.

- ALTÉS MARTÍ, Miguel Ángel (1982). La alevosía: estudio de determinados aspectos de la agravante del $n^{o} 1$ del Art. 10 del Código penal. Valencia: Universidad de Valencia. 
- Álvarez ALARCÓN, Arturo (1987). "El jurado en Portugal: estatuto, competencia y procedimiento de selección", en Anuario de la Facultad de Derecho. Universidad de Extremadura, no 5, págs. 249-276.

- Álvarez GARCíA, Francisco (dir.) (2009). Derecho Penal Español. Parte especial (I). Valencia: Tirant.

- ÁlVAREZ GARCÍA y VENTURA PÜSCHEL. (2015). "Delitos contra la vida humana independiente, homicidio y asesinato (artículos 138, 139, 140 y 140 bis)", en Comentario a la Reforma penal de 2015. (Quintero Olivares Dir.) Cizur Menor (Navarra).

- AMBOS, Kai (2006). "Preterintencionalidad y cualificación por el resultado", en Indret: Revista para el Análisis del Derecho, n 3 .

- ANDRÉ, Christophe (2017). Droit pénal spécial. París: Dalloz (4 ${ }^{a}$ ed.).

- ANTOLISEI, Francesco (2018). Manuale di Diritto Penale. Milán: Giuffrè Editore.

- ARCE FERNÁNDEZ, Ramón, TORTOSA GIL, Francisco Manuel, ALFARO, Elisa (2003). "Veredictos y análisis del contenido de las deliberaciones de los Tribunales de Jueces y Jurados en el contexto jurídico español”, en Psicothema, vol. 15, nº 1, págs. 127-135.

- ARIAS DOMÍNGUEZ, Ángel (1996-1997), "Exigencias constitucionales del Tribunal del Jurado", en Anuario de la Facultad de Derecho, $\mathrm{n}^{\circ} 14-15$, págs. 209-224.

- ARIAS EIBE, Manuel José (2005) "La circunstancia agravante de alevosía. Estudio legal, dogmático-penal y jurisprudencial”, en Revista Electrónica de Ciencia Penal y Criminología, $\mathrm{n}^{\circ} 7$.

- ARNAL, Justo, et al. (1992). Investigación educativa. Fundamentos y metodología. Barcelona: Labor. 
- BACIGAlUPO, Enrique (1996). Manual de Derecho Penal. Santa Fe de Bogotá: Temis.

- BEERNAERT, Marie-Aude; TULKENS, François; VANDERMEERSCH, Damien (2017). Code pénal. Bruselas: larcier.

- BEGUÉ LEZAUN, Juan José (2010). El proceso ante el Tribunal del Jurado. Barcelona: Bosch.

- BELlO LANDROVE, Federico (1998). "El dolo eventual en España”, en Jueces para la democracia, nº 32, pág. 16.

- BERMúdEZ REQUENA, Juan Manuel (2004). El objeto del veredicto en la Ley del Tribunal del Jurado. Granada: Comares.

○ (2008). Tribunal del jurado. Modelo y proceso. Evolución legislativa en el ordenamiento jurídico español. Valencia: Tirant.

- BRAVO, Emilio (1888). Ley del Jurado. Madrid: Biblioteca Judicial.

- BRICOLA, Franco y ZAGREBELSKY, Vladimiro (1996). Giurisprudenza sistematica di diritto penale. Turín: UTET ( $2^{\mathrm{a}}$ ed.).

- BUSTOS RAMÍREZ, Juan J. y HORMAZÁBAL MALARÉE, Hernán (2004). Nuevo sistema de Derecho Penal. Madrid: Trotta.

- CALDERÓN TELLO, Lyonel Fernando (2016). Ensayo acerca del tipo culposo o imprudente en derecho penal y su relación con la imputación objetiva. Navarra: Thomson Reuters-Aranzadi ( $1^{\mathrm{a}} \mathrm{ed}$.).

- CADENA SERRANO, Fidel Ángel (2015). Delitos de homicidio y asesinato en la reforma operada en el código penal por Ley Orgánica 1/2015. (Ponencia). 
- CANESTRARI, Stefano (2003). "La estructura del dolo eventual y las nuevas fenomenologías del riesgo", en Anales de Derecho. Universidad de Murcia, nº 21, págs. 71-108.

- CANO PAÑOS, Miguel Ángel (2017). En los límites de la exclusión de la responsabilidad penal. Barcelona: Bosch.

- CAO ABAD, Ricardo, et al. (2001). Introducción a la estadística y sus aplicaciones. Madrid: Pirámide.

- CARDENAL MONTRAVETA, Sergi (2007). "Los delitos relacionados con la seguridad del tráfico en el derecho comparado", en InDret, revista para el análisis del derecho, $\mathrm{n}^{\circ} 3$.

- CARPIO (del) DELGADO, Juana (2018). Algunas cuestiones de parte especial tras la reforma de 2015 del Código Penal. Valencia: Tirant lo Blanch.

- (2019). La prisión perpetua en el derecho internacional: un estudio sobre la teoría y su práctica por los Tribunales Penales Internacionales "Ad Hoc". Valencia: Tirant lo Blanch.

- CASALS FERNÁNDEZ, Ángela (2019). La prisión permanente revisable. Madrid: Agencia Estatal Boletín Oficial del Estado $\left(1^{\mathrm{a}}\right.$ ed.).

- CASO, Giovanni (2003). "El sistema procesal penal italiano", en Díkaion: revista de actualidad jurídica, $\mathrm{n}^{\circ} 12$.

- CERES MONTES, José Francisco (1997). Ámbito de aplicación de la Ley del jurado. Delitos y cuestiones procesales. Madrid: Colex.

- CEREZO MIR, José (2005). Curso de derecho penal español. Parte general. Madrid: Tecnos ( $6^{\mathrm{a}}$ edición). 
- CEREZO MIR, José, et al. (1999). El nuevo Código Penal: presupuestos y fundamentos: libro homenaje al Profesor Doctor Don Ángel Torío López. Granada: Comares.

- CERVELLÓ DONDERIS, Vicenta (2015). Prisión perpetua y de larga duración: régimen jurídico de la prisión permanente revisable. Valencia: Tirant lo Blanch.

- ClARCKSON, C. M. V. y KEATING, H. M. (1998). Criminal law. Text and materials. Londres: Sweet \& Maxwell.

- CRESPI, Alberto; STELlA, Federico; ZUCCALÀ, Giuseppe (1986). Comentario breve al Codice Penale. Padua: CEDAM.

- COBO DEL ROSAL, Gabriela (2012). "El proceso de elaboración del Código Penal de 1928", en Anuario de historia del derecho español, $\mathrm{n}^{\circ}$ 12, págs. 561-602.

- CORCUERA ATIENZA, Javier (1995). "La Constitución de 1978 y el jurado", en Revista del Centro de Estudios Constitucionales, nº 22, págs. 91-129.

- CORDÓN MORENO, Faustino (1996). "La sentencia y los recursos en el proceso ante el Tribunal del Jurado", en Anuario jurídico de La Rioja $\mathrm{n}^{\circ}$ 2, págs. 411-436.

- CUEllo CAlón, Eugenio (1930). El nuevo Código Penal Español. Barcelona: Bosch.

o (1975). Derecho Penal. Tomo II (Parte Especial), Vol. 2. Barcelona: Bosch ( $2^{\mathrm{a}}$ ed.).

- CUELlO CONTRERAS, Joaquín (2009). "Dolo e imprudencia como magnitudes graduales del injusto", en Revista de derecho penal y criminología, $\mathrm{n}^{\circ} 2$, págs. 37-59.

- DELPINO, Luigi (2011). Diritto Penale parte speciale. Nápoles: Edizioni Giuridiche Simone (18 ${ }^{\mathrm{a}}$ ed. $)$. 
- DÍAZ PITA, María del Mar (2006). "La presunta inexistencia del elemento volitivo en el dolo y su imposibilidad de normativización", en Revista penal, nº 17, págs. 59-61.

- DIEGO (de) DÍEZ, Luis Alfredo (2002). Recursos interlocutorios en las causas ante el Tribunal del Jurado. Barcelona: Bosch.

- DILLEHAY, R.C., BARRY-GABIER, P.J. y DAHIR, V. (2000). "La evolución del jurado en los casos criminales. Una comparación psicosocial del jurado americano y español”, en Psicología política, nº 20 , págs. 93-122.

- ELIS, Neal (2006). "Saving the Jury trial" GPSolo, vol. 23, $\mathrm{n}^{\circ}$ 2, págs. 28-29.

- ESCUDERO, José Antonio (1995). Curso de Historia del Derecho. Fuentes e Instituciones Político-Administrativas. Madrid $\left(2^{\mathrm{a}}\right.$ edición).

- FARIÑA, Francisca, ARCE, Ramón y VILA, Carlos (1999). "Efectos de la composición del jurado en los estilos deliberativos, análisis cognitivo y de contenido de la deliberación", en Anuario de Psicología, vol. 30, nº 1, págs. 150-120.

- FEIJÓO SÁNCHEZ, Bernardo (1999). Homicidio y lesiones imprudentes: requisitos y límites materiales. Zaragoza: EDIJUS.

- FELIP I SABORIT, David (2018). "El homicidio y sus formas", en SILVA SÁNCHEZ, Jesús María (dir.) y RAGUÉS I VALLÈS, Ramón (coord.). Lecciones de derecho penal. Parte especial. Barcelona: Atelier ( $5^{\mathrm{a}}$ ed.).

- FERNÁNDEZ SARASOLA, Ignacio (2006). "La primera constitución española”, en Revista de derecho: División de Ciencias Jurídicas de la Universidad del Norte, no 26, pág. 89-109. 
- FERNÁNDEZ TERUELO, Javier Gustavo (2015). Análisis de feminicidios de género en España en el período 2000-2015. Navarra: Aranzadi.

- FRISCH, Wolfgang (2015). La imputación objetiva del resultado: desarrollo, fundamentos y cuestiones abiertas. Barcelona: Atelier.

- GANZENMÜLlER, Carlos, ESCUDERO, José Francisco, FRIGOLA, Joaquín (1996). Homicidio y asesinato. Barcelona: Bosch.

- GARCÍA MORENO, José Miguel (2002). "Los Tribunales de Escabinos en el sistema procesal penal alemán”, en Jueces para la democracia, $\mathrm{n}^{\circ} 43$, págs. 83-98.

○ (2004). "El juicio penal con jurado en Inglaterra y Gales (I)", en Jueces para la democracia, no 50, págs. 87-100.

- GARCÍA-PABLOS DE MOLINA, Antonio (2006). Introducción al Derecho Penal. Madrid: Ramón Areces (4 edición).

- GILES, F. T. (1957). El Derecho Penal inglés y su procedimiento. Barcelona: Bosch.

- GIMBERNAT ORDEIG, Enrique (1985-1986). “¿Qué es la imputación objetiva?”, en Estudios penales y criminológicos, $\mathrm{n}^{\circ} 10$, pág. 167-186.

○ (1990). "Algunos aspectos de la reciente doctrina jurisprudencial sobre los delitos contra la vida (dolo eventual, relación parricidio-asesinato)", en Jueces para la democracia, nº 10 , págs. 26-35.

○ (2010). "El ocasionamiento de muerte que empieza como asesinato y termina como homicidio", Política criminal: Revista Electrónica Semestral de Políticas Públicas en Materias Penales, nº 2, págs. 195-204. 
- (2011). Cursos causales irregulares e imputación objetiva. Montevideo: B de f.

- GIMENO SENDRA, Vicente (1995). "El artículo 125 de la Constitución”. I Jornadas sobre el Jurado. Universidad de Sevilla.

- GIMENO SENDRA, Vicente, MORENO CATENA, Víctor, CORTÉS DOMÍNGUEZ, Valentín (1996). Derecho Procesal Penal. Madrid: Colex.

- GoEdSEELS, Jos. M. C. X. (1948), Commentaire du Code Pénal Belge. Tomo $2^{\circ}$. Bruselas: Établissements Émile Bruylant (2 ${ }^{\mathrm{a}}$ ed.).

- GÓMEZ COLOMER, Juan Luis (1995). El proceso penal alemán. Introducción y normas básicas. Barcelona: Bosch.

- GÓMEZ RIVERO, Ma del Carmen (2000). "Presupuestos y límites de la alevosía y el ensañamiento en el Código Penal”, en Revista de derecho y proceso penal, $\mathrm{n}^{\circ}$ 4, págs. 35-59.

- GÓMEZ RIVERO, Ma del Carmen (coord.) (2010). Nociones fundamentales de derecho penal. Parte general. Madrid: Tecnos.

- GÓMEZ RIVERO, Ricardo (1997). "El Tribunal del Jurado en Albacete en la II República", en Anuario de historia del derecho español, $\mathrm{n}^{\circ}$ 67, págs. 1527-1546.

- GONZÁLEZ CUSSAC, J. L. (coord.) (2016). Derecho Penal parte especial. Valencia: Tirant ( $5^{\mathrm{a}}$ ed.).

- GONZÁLEZ JIMÉNEZ, Magdalena (2006). La institución del jurado: la experiencia española. Madrid: La Ley.

- GONZÁLEZ PILLADO, Esther (2000). Instrucción y preparación del juicio oral en el procedimiento ante el tribunal del jurado. Granada: Comares. 
- GONZÁLEZ PILLADO, Esther y VILLAGÓMEZ CEBRIÁN, Marco (2005). El Tribunal del Jurado. Madrid: Boletín Oficial del Estado.

- GONZÁleZ RUS, Juan José. et al. (1996), en Curso de Derecho Penal Español. Parte Especial I. Madrid: Marcial Pons.

- GRACIA MARTíN, Luis (2007). Los delitos de homicidio y de asesinato en el Código Penal Español. Doctrina y jurisprudencia. Valencia: Tirant lo Blanch.

- GRANADOS PÉREZ, Carlos (2000), “Objeto material en los delitos contra las personas", en Delitos contra las personas. Madrid: Consejo General del Poder Judicial, págs. 241-269.

- GROIZARD Y GÓMEZ DE LA SERNA, Alejandro (1902). El Código penal de 1870: concordado y comentado. Madrid: Establecimiento Tipográfico de los Hijos de J. A. García (2 $2^{a}$ ed.).

- GUDÍN RODRÍGUEZ-MAGARIÑOS, Faustino (2009). El estado de derecho frente a la tortura. Valencia: Tirant.

- GUTIÉRREZ SANZ, Ma Rosa (1996). "El estatuto jurídico del ciudadano jurado desde la perspectiva de la Ley Orgánica del Tribunal del Jurado", en Anuario jurídico de La Rioja nº 2, págs. 345-368.

- HAAS, Volker (2016). "La doctrina penal de la imputación objetiva", en Indret: Revista para el Análisis del Derecho, $\mathrm{n}^{\circ} 1$.

- HABERL, Helmut (1981). Das österreichische Strafgesetzbuch. Graz.

- HELMHOLZ, R. H. (1983). "The Early History of the Grand Jury and the Canon Law", en The University of Chicago Law Review, vol. 50, nº 2, pág. 626. 
- HERNÁNDEZ DE LA RÚA, Vicente (1859). Código Penal Reformado. Madrid.

- HOPKINS, Kennet D., HOPKINS, B.R. y GLASS, Gene V. (1997). Estadística básica para las ciencias sociales y del comportamiento. México: Prentice-Hall ( $3^{\mathrm{a}}$ ed.).

- IGUARTUA SALAVERRÍA, Juan (2013). La "sucinta explicación" en el veredicto del jurado. Valencia: Tirant.

- IÑESTA PASTOR, Emilia. (2011). El Código Penal Español de 1848. Valencia: Tirant.

- JACOB, Joe (1986). "El procedimiento legislativo en el Parlamento británico", en Revista española de derecho constitucional, $\mathrm{n}^{\circ} 16$, págs. 179-202.

- JAVATO MARTín, Antonio María (2005). El delito de atentado. Modelos legislativos. Estudio histórico-dogmático y de Derecho comparado. Granada: Comares.

- JORGE BARREIRO, Alberto, et al. Juicio por jurado. Cuestiones teóricas y prácticas. Madrid: Dykinson.

- KINDHÄUSER, Urs (2006). "Imputación objetiva y subjetiva en el delito doloso", en Anuario de derecho penal y ciencias penales, Tomo 59, Fasc/Mes 1, págs. 63-82.

- KLOTTER, John C. (2001). Criminal Law. Cincinnati: Anderson (6 ed.).

- KUNKEL, W. (1989). Historia del derecho romano. Barcelona: Ariel Derecho.

- KÜPPER, Georg (1996). Strafrecht Besonderer Teil 1. Delikte gegen Rechtsgüter der Person und Gemeinschaft. Berlín: Springer Lehrbuch. 
- LAMARCA PÉREZ, Carmen (coord.) (2017). Delitos. La parte especial del Derecho penal. Madrid: Dykinson ( $2^{\mathrm{a}}$ ed.).

- LANDECHO VELASCO, Carlos María y MOLINA BLÁZQUEZ, Concepción. (2017). Derecho penal español. Parte general (10 ed.). Madrid: Tecnos.

- LARA LÓPEZ, Antonio María (2014). El recurso de apelación y la segunda instancia penal. Navarra: Thomson Reuters Aranzadi.

- LARRAURI, Elena (1987-1988). "Introducción a la imputación objetiva”, en Estudios penales y criminológicos, n 12 , págs. 219248.

- LEÓN, Orfelio G. y MONTERO, Ignacio (1997). Diseño de investigaciones. Madrid: McGraw.Hill (2 ${ }^{\mathrm{a}}$ ed.).

- LOMBARD, Françoise (1993). Les jurés. Justice représentative et représentations de la justice. París: L’Harmattan.

- LÓPEZ BARJA DE QUIROGA, Jacobo (1999). Instituciones de derecho procesal penal. Madrid: Akal Iure.

- LÓPEZ GARRIDO, Diego y GARCÍA ARÁN, Mercedes (1996). El Código Penal de 1995 y la voluntad del legislador. Madrid.

- LÓPEZ GOBERNADO, Carlos J. (2011). "Investigación criminal en la antigua Roma", en Quadernos de Criminología, n 12, págs. 1621.

- LÓPEZ JIMÉNEZ, Raquel (2002). La prueba en el juicio por jurados. Valencia: Tirant.

○ (2009). "El jurado como forma de ejercicio democrático", en Nuevas Políticas Públicas: Anuario multidisciplinar para la modernización de las Administraciones Públicas, $\mathrm{n}^{\circ}$ 5, pág. 221-236. 
- LÓPEZ-REY, Manuel y ÁLVAREZ-VALDÉS, Félix (1933). El nuevo Código Penal. Madrid: Revista de Derecho Privado.

- LORCA NAVARRETE, Antonio María (2004). Jurisprudencia comentada de las sentencias del Tribunal Supremo sobre el proceso penal con Tribunal del Jurado, vol. V. Guipúzcoa: Instituto Vasco de Derecho Procesal.

- LUZÓN CUESTA, José María (1993). El recurso de casación penal. Madrid: Colex

- (2001). Compendio de Derecho Penal. Parte general. Madrid: Dykinson.

- MACNAIR, Mike (1999). "Law, Politics and the Jury", en Law and History Review, vol. 17, nº 3, págs. 603-607.

- MAGRO SERVET, V. (2003). Guía práctica de problemas y soluciones planteadas ante el Tribunal del Jurado. Madrid: La Ley.

- MAPELli CAFFARENA, Borja (1988). "El dolo eventual en el asesinato", en Anuario de derecho penal y ciencias penales, Tomo 41, Fasc/Mes 2, págs. 431-464.

- MARES ROGER, Francisco y MORA ALARCÓN, José Antonio (1996). Comentarios a la Ley del Jurado. Valencia: Tirant.

- MARÍN DE ESPINOSA CEBALLOS, Elena (dir.) y ESQUINAS VALVERDE, Patricia (coord.). Lecciones de Derecho penal. Parte especial. Valencia: Tirant lo Blanch.

- MARÍN GÁMEZ, José Ángel (2003-2004). "Ocho años de Tribunal del Jurado", en Revista de derecho político, no 58-59, págs. 685-706.

- MARTÍN GARCÍA, Pedro, et al. (1999). Los recursos penales. Valencia: Revista General de Derecho.

- MARTÍN PALLÍN, José Antonio, et al. (2006). La Ley del Jurado en su X Aniversario. Navarra: Thomson Aranzadi. 
- MARTÍNEZ-PUJALTE, Antonio-Luis (2018). "La participación de las personas con discapacidad en la institución del Jurado", en Revista de derecho político, $\mathrm{n}^{\circ}$ 103, pág. 331-353.

- MARTOS NÚÑEZ, Juan Antonio (1994). "La circunstancia de precio, recompensa o promesa en el Sistema Penal Español", en Poder Judicial, nº 36, págs. 51-105.

- (2017). El delito de asesinato. Análisis de la L.O. 1/2015 de 30 de marzo, de Reforma del Código Penal. Barcelona: Bosch.

- MENDES DE CARVALHO, Gisele (2009). Suicidio, eutanasia y Derecho penal. Granada: Comares.

- MIR PUIG, Santiago (2003). "Significado y alcance de la imputación objetiva en derecho penal", en Revista Electrónica de Ciencia Penal y Criminología., nº 5, págs. 1-19.

- MODOLELl GONZÁLEZ, Juan Luis (2005). “Consideraciones teóricas sobre la posibilidad de extensión de la imputación objetiva a los delitos de mera actividad", en BOLAÑOS GONZÁLEZ, Mireya (compiladora) Imputación objetiva y dogmática penal. Venezuela: Mérida, págs. 229-248.

- MONTERO AROCA, Juan (1996). Los recursos en el proceso ante el Tribunal del Jurado. Granada: Comares.

- MONTERO AROCA, Juan y GÓMEZ COLOMER, Juan Luis (coords.) (1999). Comentarios a la Ley del Jurado. Navarra: Aranzadi.

- (del) MORAL GARCÍA, Antonio (1994). “Anotaciones al Proyecto de Ley Orgánica del Tribunal del Jurado", en Jueces para la democracia, $\mathrm{n}^{\circ} 22$, págs. 65-75. 
- MORALES PRATS, Fermín, en QUINTERO OLIVARES, Gonzalo (dir.); MORALES PRATS, Fermín (coord.). (2016). Comentarios a la parte especial del Derecho Penal. Navarra: Aranzadi (10 ed.).

- MORENO, Juan Damián (1997). “El juez de instrucción en los procesos atribuidos al Tribunal del Jurado. Un típico fenómeno de desdoblamiento de personalidad", en Jueces para la democracia, $\mathrm{n}^{\circ}$ 29, págs. 34-36.

- MORGAN, Rod y EVANS, Malcom (2002). Combattre la torture en Europe. Council of Europe Publishing.

- MUERZA ESPARZA, Julio J. (1996). “Ámbito de aplicación, competencia y procedimiento para las causas ante el tribunal del jurado", en Anuario jurídico de La Rioja, nº 2, págs. 369-396.

○ (2010). "Sobre la competencia del tribunal del jurado por conexión”, en Actualidad jurídica Aranzadi, 798, pág. 19.

- MUÑOZ CONDE, Francisco (2015). Derecho Penal. Parte Especial. Valencia: Tirant ( $20^{\mathrm{a}}$ ed.).

○ (2016). "El delito de asesinato tras la reforma penal del 2015", en Cuestiones penales. A propósito de la Reforma penal de 2015. Madrid: Dykinson, págs. 17-31.

- NARVÁEZ RODRÍGUEZ, Antonio (1995). El jurado en España. Granada: Comares.

- NOVO PÉREZ, Mercedes, ARCE FERNÁNDEZ, Ramón y SEIJO MARTÍNEZ, Dolores (2002). "El tribunal del Jurado en Estados Unidos, Francia y España: tres modelos de participación en la administración de Justicia. Implicaciones para la educación del ciudadano", en Publicaciones, no 32, págs. 335-360.

- NÚÑEZ PAZ, Miguel Ángel (2016). Interrupción voluntaria de la vida humana. Valencia: Tirant lo Blanch. 
- OLIVA (de la) SANTOS, Andrés (coord.) (1999). Comentarios a la Ley del Jurado. Madrid: Centro de Estudios Ramón Areces.

- ORTS BERENGUER, Enrique (2017). Compendio de Derecho Penal. Parte general. Valencia: Tirant lo Blanch ( $\left.7^{\mathrm{a}} \mathrm{ed}.\right)$.

- PANTALEÓN DÍAZ, Marta y SOBEJANO NIETO, Diego (2014). "El asesinato para facilitar la comisión de otro delito o para evitar que se descubra: la propuesta de dos nuevas modalidades de asesinato en el Código Penal español", en Revista Jurídica de la Universidad Autónoma de Madrid, nº 29, págs. 213-237.

- PAREDES CASTAÑÓN, José Manuel (2001). "Problemas metodológicos en la prueba del dolo", en Anuario de filosofía del derecho, nº 18, págs. 67-94.

- PENAARANDA RAMOS, Enrique (2014). Estudios sobre el delito de asesinato. Montevideo: Buenos Aires: B de f.

○ (2016). "Los delitos de homicidio y asesinato tras la reforma de 2015 del Código Penal", en Estudios de Derecho Penal Estudios de Derecho penal: homenaje al profesor Miguel Bajo. Madrid: Ramón Areces.

- PÉREZ CEBADERA, Mángeles (2017). Las instrucciones al jurado. Valencia: Tirant ( $2^{\mathrm{a}}$ ed.).

- PÉREZ-CRUZ MARTÍN, Agustín, et al. (1996). Comentarios sistemáticos a la Ley del Jurado y a la reforma de la prisión preventiva. Granada: Comares.

- PÉREZ-PRENDES, José Manuel y AZCARRAGA (de), Joaquín (1989). Lecciones de historia del derecho español. Madrid: Centro de Estudios Ramón Areces.

- PÉREZ DEL VALLE, Carlos (2012). La imprudencia en el derecho penal: el tipo subjetivo del delito imprudente. Barcelona: Atelier. 
- PÉREZ VAQUERO, Carlos (2011). “La cadena perpetua es un trato inhumano?", en Quadernos de Criminología, no 15, pág. 54.

- QUINTERO OLIVARES, Gonzalo (dir.); MORALES PRATS, Fermín (coord.). (2016). Comentarios a la parte especial del Derecho Penal. Navarra: Aranzadi (10 ed.).

- RAGUÉS I VALLÈS, Ramón (1999). El dolo y su prueba en el proceso penal. Barcelona: Bosch.

- RAMÓN RIBAS, Eduardo (2010). "El homicidio preterintencional", en Revista de derecho penal y criminología, no 3, págs. 135-177.

- RINCÓN (del) IGEA, Delio, et al. (1995). Técnicas de investigación en ciencias sociales. Madrid: Dykinson.

- RÍO (del) MONTESDEOCA, Luis (2017). Los delitos de homicidio $y$ lesiones imprudentes en el ámbito laboral. Valencia: Tirant lo Blanch.

- ROCA AGAPITO, Luis (2005). "Inducción mediante precio y cooperación con el sicario en la muerte del marido. La supuesta función unificadora de la jurisprudencia del Tribunal Supremo", en Revista de derecho penal y criminología, nº 15, pág. 263-306.

- ROIG TORRES, Margarita (2016). La cadena perpetua en el derecho alemán y británico, la prisión permanente revisable. Madrid: Iustel.

- ROMEO CASAbONA, Carlos María; SOLA RECHE, Esteban y BOLDOVA PASAMAR, Miguel Ángel (coords.) (2016). Derecho Penal parte general. Introducción a la teoría jurídica del delito. Granada: Comares ( $2^{\mathrm{a}}$ ed.).

- (2016). Derecho Penal parte especial. Conforme a las Leyes Orgánicas 1 y 2/2105, de 30 de marzo. Granada: Comares. 
- ROSAL (del) BLASCO, Bernardo (1992). "Política criminal de los delitos contra la vida humana independiente en el proyecto de Código Penal de 1922", en Anales de la Universidad de Alicante, $\mathrm{n}^{\circ}$ 7, Facultad de Derecho, págs. 133-146.

○ (2000), "La alevosía en el Código Penal de 1995”, en Delitos contra las personas. Madrid: Consejo General del Poder Judicial, págs. 271-298.

- ROXIN, Claus (1997). Derecho penal. Parte general. Tomo I, Fundamentos, la estructura de la teoría del delito. Madrid: Civitas.

- (2003). Desviación del curso causal y dolus generalis. Buenos Aires: Hammurabi.

○ (2007). "Injerencia e imputación objetiva", en Revista penal, nº 19 , págs. 152-161.

- RUBENSTEIN, Arie M. (2006). "Veredicts of Conscience: Nullification and the Modern Jury Trial", en Columbia Law Review, Vol. 106, nº 4, págs. 959-993.

- SAldAÑA, Quintiliano (1920). Comentarios al Código Penal de 1870 (vol. I). Madrid: Reus.

- SÁNCHEZ-MÁlAGA, Armando (2018). Una teoría para la determinación del dolo: premisas teóricas e indicadores prácticos. Montevideo: B de F.

- SÁNCHEZ OSÉS, José (1956), "La codificación del Derecho penal en Inglaterra", en Anuario de derecho penal y ciencias penales, Tomo 9, Fasc/Mes 2, págs. 267-298. Ministerio de Justicia.

- SÁNCHEZ-VERA GÓMEZ TRELLES, Javier (2016). "Un reto para el dolo: los motivos del autor", en Derecho Penal para un estado social y democrático de derecho. Estudios penales en homenaje al profesor Emilio Octavio de Toledo y Ubieto, págs. 339-363. Madrid: Servicio de Publicaciones de la Facultad de Derecho de la UCM. 
- SANTISTEBAN RUIZ, Alfonso (1996). "El veredicto", en Anuario jurídico de La Rioja, nº 2, págs. 397-410.

- SANZ-DÍEZ DE ULZURRUN LLUCH, Marina (2007). Dolo $e$ imprudencia en el Código Penal Español. Valencia: Tirant lo Blanch.

- SANZ HERMIDA, Ágata $\mathrm{M}^{\mathrm{a}}$ (2009). Víctimas de delitos: derechos, protección y asistencia. Madrid: Iustel.

- SANZ MORÁN, Ángel José (1995). "Presupuestos para la reforma de los delitos contra la vida", en Anuario de derecho penal y ciencias penales, Tomo 48, Fasc/Mes 3, págs. 783-848.

○ (2003) "Algunas consideraciones sobre culpabilidad y pena", en Revista de derecho penal, $\mathrm{n}^{\circ}$ 8, págs. 13-29.

○ (2016) "La reforma de los delitos contra la vida", en Derecho Penal para un estado social y democrático de derecho. Estudios penales en homenaje al profesor Emilio Octavio de Toledo y Ubieto, págs. 821-838. Madrid: Servicio de Publicaciones de la Facultad de Derecho de la UCM.

- SARABIA ALEGRÍA, José María (2000). Curso práctico de estadística. Madrid: Civitas ( $2^{\mathrm{a}}$ ed.).

- SEOANE SPIEGELBERG, José Luis (1998). "Incoación e investigación en el procedimiento ante el tribunal del jurado", en Anuario da Facultade de Dereito da Universidade da Coruña, ${ }^{\circ} 2$, págs. 511-526.

- SERRANO GÓMEZ, Alfonso, et al. (2016). Curso de Derecho Penal parte especial. Madrid: Dykinson.

- SEVERINO, Mashgsimo (1974). Codice Penale. Roma: Jandi Sapi.

- SILVA SÁNCHEZ, Jesús-María (dir.) (2006). Lecciones de derecho penal. Parte especial. Barcelona: Atelier. 
- SILVELA, Luis (1884). El derecho penal estudiado en principios y en la legislación vigente en España. Madrid: Manuel G. Hernández.

- STAMPA BRAUN, José María (1950). "El objeto material de los delitos contra la vida", en Anuario de derecho penal y ciencias penales, tomo 3, fasc/mes 3, págs. 519-555.

- SUÁREZ, C. y RODRÍGUEZ, M. (2015). "Del homicidio y sus formas", en Comentarios a la Reforma del Código Penal de 2015. Valencia. Tirant, págs. 465-486.

- TAMARIT SUMALLA, Josep María (2019). "El nuevo tratamiento legal de la imprudencia y el delito de abandono en el lugar del accidente", en QUINTERO OLIVARES, Gonzalo, et al. Las Reformas Penales de 2019. Navarra: Thomson Reuters Aranzadi, págs. 17-35.

- TERRADILlos BASOCO, José María (coord.), Lecciones y materiales para el estudio del Derecho Penal. Tomo III. Derecho Penal parte especial (vol. I).

- TOMÉ GARCÍA, José Antonio (2013). Recurso de apelación contra sentencias en el proceso penal. Madrid: Colex.

- TORÍO LÓPEZ, Ángel (1983). "Estudio de la reforma de los delitos contra la vida (parricidio-asesinato)", en RODRÍGUEZ DEVESA, José (coord.), Repercusiones de la Constitución en el Derecho penal, Bilbao: Universidad de Deusto.

- TORRENT, Armando (1988). Derecho público romano y sistema de fuentes. Zaragoza ( $4^{\mathrm{a}} \mathrm{ed}$.).

- VARELA CASTRO, Luciano (dir.) (1995). El Tribunal del Jurado. Madrid: Consejo General del Poder Judicial.

- VÉRON, Michel (2006). Droit pénal spécial. París: Dalloz (11 a ed.). 
- VIADA Y VILASECA, Salvador (1877). Código Penal reformado, de 1879. Madrid.

- VICENTE MARTÍNEZ, Rosario (de) (2018). Alcohol, drogas y delitos contra la seguridad vial. Madrid: Reus.

- VILATA MENADAS, Salvador (2001). "El Tribunal del Jurado y los deberes positivos generales", en Boletín del Ministerio de Justicia, Año 55, nº 1892, págs. 1521-1538.

- VILlanUEVA TURNES, Alejando (2016). "La objeción de conciencia y el Tribunal del Jurado en España”, en Inciso, Vol. 18, $n^{\circ}$ 2, págs. 37-45.

- VORMBAUM, Thomas (2018). Historia moderna del derecho penal alemán. Valencia: Tirant lo Blanch.

- VV.AA., (2008). "Análisis de las sentencias dictadas por los Tribunales del jurado en el periodo 2001-2005, relativas a homicidios o asesinatos entre los miembros de la pareja o ex-pareja", en Revista jurídica de igualdad de oportunidades entre hombres y mujeres, $\mathrm{n}^{\circ} 22$, págs. 50-62.

- YÁÑEZ VELASCO, Ricardo (2001). Derecho al recurso en el proceso penal. Valencia: Tirant lo Blanch.

○ (2001). El recurso en el enjuiciamiento criminal español. Barcelona: Atelier.

○ (2014). La institución del jurado. Introducción a su estudio psicosocial. Madrid: Reus.

- ZAFFARONI, Eugenio Raúl (1980) "Una experiencia notable: El nuevo derecho penal austriaco", en Anuario de derecho penal y ciencias penales, tomo 33, Fas/Mes 3, págs. 707-729. 


\section{LEGISLACIÓN ESPAÑOLA}

- Constitución Española de 1812.

- Constitución Española de 1837.

- Constitución Española de 1869.

- Constitución Española de 1978.

- Código Penal de 1822.

- Código Penal de 1848.

- Código Penal de 1870.

- Código Penal de 1928.

- Código Penal de 1832.

- Código Penal de 1844 y texto refundido de 1973.

- Ley Orgánica 1/1979, de 26 de septiembre, General Penitenciaria (LOGP).

- Ley Orgánica 8/1983, de 25 de junio, de reforma urgente y parcial del Código Penal.

- Ley Orgánica 5/1985, de 19 de junio, del Régimen Electoral General (LOREG).

- Ley Orgánica 6/1985, de 1 de julio, del Poder Judicial (LOPJ).

- Ley Orgánica 5/1995, de 22 de mayo, del Tribunal del Jurado (LOTJ).

- Ley Orgánica 10/1995, de 23 de noviembre, del Código Penal.

- Ley Orgánica $1 / 2015$, de 30 de marzo, por la que se modifica la Ley Orgánica 10/1995, de 23 de noviembre, del Código Penal.

- Ley Orgánica 1/2017, de 13 de diciembre, de modificación de la Ley Orgánica 5/1995, de 22 de mayo, del Tribunal del Jurado, para garantizar la participación de las personas con discapacidad sin exclusiones. 
- Ley Orgánica $2 / 2019$, de 1 de marzo, de modificación de la Ley Orgánica 10/1995, de 23 de noviembre, del Código Penal, en materia de imprudencia en la conducción de vehículos a motor o ciclomotor y sanción del abandono en el lugar del accidente.

- Ley sobre la libertad de imprenta, de 22 de octubre de 1820.

- Ley sancionada sobre la formación del jurado en las capitales de provincia, de 20 de julio de 1842.

- Ley Provisional sobre Organización del Poder Judicial, de 15 de septiembre de 1870 .

- Ley de Enjuiciamiento Criminal, de 14 de septiembre de 1882 (LECr).

- Ley del Jurado, de 20 de abril de 1888.

- Ley 41/2015, de 5 de octubre, de modificación de la Ley de Enjuiciamiento Criminal para la agilización de la justicia penal y el fortalecimiento de las garantías procesales.

- Decreto de 28 de abril de 1931.

- Decreto de 6 de agosto de 1933.

- Decreto de 2 de octubre de 1934.

- Real Decreto 1398/1995, de 4 de agosto, regulador del sorteo para la formación de las listas de candidatos a jurados.

- Real Decreto 385/1996, de 1 de marzo, regulador del Régimen retributivo e indemnizaciones del desempeño de las funciones de jurado.

- Real Decreto 2067/1996, de 13 de septiembre, por el que se modifica el RD 1398/1995.

- Resolución de 21 de julio de 2006, de la Subsecretaría, por la que se dispone la publicación del Acuerdo del Consejo de Ministros de 14 de julio de 2006, por el que se revisan las cuantías de las 
retribuciones e indemnizaciones correspondientes al desempeño de la función del Jurado. 


\section{LEGISLACIÓN INTERNACIONAL}

- Code de Procédure Pénale (Francia).

- Code Pénal (Bélgica, 1867).

- Code Pénal (Francia, 1992).

- Codice di procedura penale (Italia).

- Codice penale (Italia) (Real Decreto de 19 de octubre de 1930).

- Código de Processo Penal. DL no 78/87, de 17 de febrero (Portugal).

- Código Penal de Austria (1975).

- Código Penal de Canadá.

- Código Penal de Suiza (1937).

- Constitución de Alemania (1949).

- Constitución de Francia, de 4 de octubre de 1958.

- Constitución de Estados Unidos (1787).

- Constitución de Italia (1947).

- Constitución de Portugal (1976).

- Convención Europea de Derechos Humanos (1950).

- Corporate Manslaughter and Corporate Homicide Act (Reino Unido, 2007).

- $\mathrm{DL} \mathrm{n}^{\circ}$ 387/87, de 29 de diciembre, sobre el Régimen del Jurado en el Proceso Penal (Portugal).

- Decreto-Lei 48/95 (Código Penal de Portugal).

- (Gerischtsverfassungsgesetz, GVG) (Ley Orgánica de Tribunales, Alemania).

- Homicide Act (Reino Unido, 1957).

- Juries Act (JA), (Reino Unido, 1974).

- Jury Selection and Service Act (Estados Unidos, 1968). 
- Ley no 3/99, de 13 de enero, de Organización y Funcionamiento de los Tribunales (LOFTJ) (Portugal).

- Pacto Internacional de Derechos Civiles y Políticos, de 19 de diciembre de 1966.

- Riordinamiento dei giudizi de Assise, Ley 287, de 10 de abril de 1951 (Italia).

- Strafgesetzbuch (StGB, Código Penal de Alemania, 13 de noviembre de 1998).

- Wetboek van Strafrecht (Código Penal de los Países Bajos). 


\section{WEBGRAFÍA}

- American Bar Association: https://www.americanbar.org

- BOE: Boletín Oficial del Estado: https://www.boe.es/

- CENDOJ: Centro de Documentación Judicial del Consejo General del Poder Judicial: http://www.poderjudicial.es/search/indexAN.jsp

- Congreso de los Diputados: http://www.congreso.es

- Consejo General del Poder Judicial: http://www.poderjudicial.es/cgpj/es

- Consiglio Superiore della Magistratura: https://www.csm.it

- ConstitutionFacts: https://www.constitutionfacts.com

- Cornell Law School: https://www.law.cornell.edu

- DRE: Diário da República Electrónico: https://dre.pt

- European Justice: https://e-justice.europa.eu

- Fiscalía General del Estado: https://www.fiscal.es

- HUDOC: https://hudoc.echr.coe.int

- IPSOA: http://www.ipsoa.it

- Justice UK: www.justice.gov.uk

- Legifrance: https://www.legifrance.gouv.fr

- Legislación del Reino Unido: http://www.legislation.gov.uk

- Ministerio de Justicia de Alemania: http://www.gesetze-im-internet.de

- Ministero della Giustizia: https://www.giustizia.it/giustizia/

- Naciones Unidas. Oficina del Alto Comisionado: http://www.ohchr.org

- Normattiva. Il portale della legge vigente: http://www.normattiva.it

- Portal Iberoamericano de las Ciencias Penales: http://www.cienciaspenales.net

- Procuradoria-Geral Distitral del Lisboa: http://www.pgdlisboa.pt

- The Avalon Project: Documents in Law, History and Diplomacy: http://avalon.law.yale.edu

- Tribunal Europeo de Derechos Humanos (Consejo de Europa): http://www.echr.coe.int

- US Supreme Court: https://supreme.justia.com

- Verheid: http://wetten.overheid.nl

- Wipo Lex: http://www.wipo.int/wipolex/es 